\title{
Fighting Back After the Neoliberal Assault: Class Formation, Class Politics, and the Canadian Autoworkers
}

by

\author{
Tim Fowler
}

A thesis submitted to the Faculty of Graduate and Postdoctoral Affairs

in partial fulfillment of the requirements for the degree of

Doctor of Philosophy in Political Science \& Political Economy

Carleton University

(C) Copyright by Tim Fowler, 2015 


\begin{abstract}
$\underline{\text { Abstract }}$
This dissertation examines the Canadian Autoworkers union (CAW) during an age of neoliberal globalization. The dissertation places particular emphasis on internal dynamics and the way these played a key role in shaping class formation within the union, focusing on the interactions between the rank-and-file delegates and leadership at CAW Council. The dissertation also examines the implications for class formation, deformation, and reformation in the neoliberal era. Particular attention is focused on the CAW Council, a key institution within the union that connects rank-and-file activists to the national leadership and acts as a ground for 'mid-tier' activists to organize, pursue strategy, and push for change within the union. A great deal of union policy and strategy - including electoral strategy - was developed at Council, where the leadership would present reports, which were then subject to debate by the members. The dissertation argues that Council thus acted as an important meeting ground for members of the union and provided a space for activists to challenge the leadership on key issues.
\end{abstract}

The dissertation also uses the CAW to look at how unions can constitute themselves as classactors but this does not mean that other identities were ignored. The CAW was frequently a leader, especially among industrial unions, on equity politics. Members of equity seeking groups pressed for inclusion within the structures of the union, and, in turn, the union was able to make real gains for equity seeking members at the bargaining table. The equity politics of the CAW were based on the union shaping a common identity as members of the working class, while highlighting that equity seekers faced particular barriers on the job, in the union, and in the broader Canadian society that the union could help challenge. Particular attention is paid to the way the leadership embraced equity issues, often after being pushed by equity seeking activists, and how they relayed the importance of equity issues to the broader union membership.

In two areas - concessions bargaining and electoral politics - however, the union appears to have shifted from its original position. Although the CAW split from the international United Autoworkers over the issue of concessions at the bargaining table, which the Canadian affiliate was unwilling to accept, the CAW ultimately accepted concessions. In addition, the CAW gradually embraced an electoral strategy of strategic voting in response to the New Democratic Party's inability to present a clear electoral alternative to neoliberalism. Both shifts reflected the union's changing caluculus of how best to protect the automotive industry, and, thus, the jobs of its members in the face of neoliberal globalization. 


\section{Acknowledgements}

My earliest political memory is attending a rally in an arena in Welland, put on by the OSSTF, against Bill 116 of the Mike Harris government in Ontario. I was taken there by my dad, a highschool teacher. My dad, David Fowler, was an activist within the OSSTF and the NDP, and he was my first introduction to leftist politics and the trade union movement. Without this introduction, I doubt this dissertation would have come to light. Besides this introduction to politics, I will be forever indebted to my dad, and my mum, Janet Hodgkins, for the support emotional and financial - through all my many, many years of schooling.

I owe a great academic debt to Dan Crow, who taught me both the Politics of Labour and my introduction to political economy course in my undergrad. Dan has since become one of my best friends and a great intellectual guide to me through the last decade of my political and academic life. Informal discussions with him about political economy, Marxism, the Canadian trade union movement, and the CAW have greatly helped to shape my thinking and this dissertation.

I also owe a great debt to a fantastic advisory committee. Rianne Mahon has provided excellent guidance of a caliber I could not imagine when I started this project. She has helped me craft my sprawling and tangential ideas into what I hope is a finely tuned dissertation, and has guided me through especially tricky theoretical concepts. I also owe a debt of gratitude to Christina Gabriel and Rosemary Warskett for their ideas, guidance, and feedback on this project.

This project would not have, frankly, been possible without the assistance of three people at the, or formerly with, the CAW. Kathy Bennett, the CAW's librarian, made the research for the project possible. Kathy gave me access to the archives at the CAW, guided me through the useful material, and was gracious enough to let me take material home with me so I could pour through it on my own time. Kathy pointed me in the direction of useful information, and helped me fill in the gaps in my research. I am also indebted to Jim Stanford and Sam Gindin. Jim and Sam both provided me with preliminary interviews, before this project started, to help guide me and give me some ideas on how to frame the project. Further, and most importantly, Jim and Sam both assisted me in finding and setting up interviews with many of the people who I wanted to talk to through this project. I would also like to thank my interviewees for spending time talking to me.

Throughout my PhD program the process of writing this dissertation, I received a great deal of informal, and sometimes formal help. I would like to thank Jeff Boggs, Jonah Butovsky, Dan Crow, Blayne Haggart, Paul Hamilton, Sanjay Jeram, and Larry Savage for reading sections of chapters and providing feedback, discussing theoretical stumbling blocks with me, allowing me to invade their offices at Brock to bounce ideas off of them, and pointing me in the direction of literature which helped shape my thinking.

My time in Ottawa was made better by my friends there. One of the best parts of my coursework was making new friends in the academy. I was also very thankful to have a group of friends to play board games with, see music with, and generally become distracted from the academy with. To this end, I would like to thank Steve \& Colleen Armstrong, Dan Arnott, Chris \& Sally Busch, 
iii

Daryl Kaytor, and Ajay Parasram for their friendship.

Similarly, my friends in St. Catharines provided me with much needed distractions in the form of board games, baseball games, and time away from my dissertation. The friendship of Colin Anderson, Jay Farrer, Brandi Kehoe, Kevin Kortekaas, Rob MacNinch, Christopher MaGarrey, Tim Patton, Doug Pirko, Steve Romanin, and Drew Wade was invaluable.

Lastly, I wish to acknowledge the friendship of some of my closest friends. While they napped on my notes, walked across my keyboard when I was writing, stole my pens, and generally placed themselves in the way and underfoot, my nonhuman animal companions made the process of writing this dissertation much more bearable. Thanks, then, to Blossom, Tess, Junior, Ginger Snap, and to Penelope, my beloved beagle, may she rest in peace. 


\section{iv \\ $\underline{\text { Table of Contents }}$}

Acknowledgements

List of Tables and Figures $\quad$ V

List of Abbreviations Used vi

Introduction $\quad 1$

Theoretical Framework \& Methods 13

$\begin{array}{ll}\text { History } & 52\end{array}$

Free Trade, Plant Closures, and The Changing Fight-Back Strategy 94

$\begin{array}{ll}\text { Equity, Class, and the CAW } & 138\end{array}$

$\begin{array}{ll}\text { The CAW, elections, and Extra-Parliamentary Politics } & 177\end{array}$

$\begin{array}{ll}\text { Conclusion } & 221\end{array}$

$\begin{array}{ll}\text { Works Cited } & 234\end{array}$ 


\section{$\underline{\text { List of Tables and Figures }}$}

3 - 1: Overall manufacturing footprint, 1981 - 1996.

97

3 - 2: Transportation equipment industries footprint, 1981 - 1996.

97

3 - 3: Persons employed, all manufacturing industries, 1981 - 1997.

98

3 - 4: Persons employed, transportation manufacturing industries, 1981 - 1997.

98

$3-5$ : New members organized. 
vi

\section{List of Abbreviations Used}

The Big Three

CALEA

CAW

CCF

CEP

CLC

CUPE

CUPW

FTAA

FTQ

OEN

OLRB

OPEC

NAFTA

NEB

NDP

OFL

ONDP

NPI

PEL

PSAC

SACTU

UAW

UFCW

USWA

WFC
Ford, Chrysler, and General Motors (GM), the three largest North

American automotive producers.

Canadian Air Line Employee's Association

The Canadian Autoworkers Union, formally the National Automobile, Aerospace, Transportation and General Workers Union of Canada.

The Cooperative Commonwealth Federation.

Communications, Energy and Paperworkers Union of Canada.

Canadian Labour Congress.

The Canadian Union of Public Employees.

Canadian Union of Postal Workers.

Free Trade Area of the Americas.

Fédération des travailleurs et travailleuses du Québec (Quebec Federation of Labour)

Ontario Election Network.

Ontario Labour Relations Board.

Organization of the Petroleum Exporting Countries.

North American Free Trade Agreement.

The National Executive Board of the CAW.

New Democratic Party.

The Ontario Federation of Labour.

New Democratic Party of Ontario.

New Politics Initiative.

Paid Education Leave.

The Public Service Alliance of Canada.

The South African Congress of Trade Unions.

The United Autoworkers, formally The International Union, United

Automobile, Aerospace and Agricultural Implement Workers of America.

The United Food and Commercial Workers.

The United Steelworkers of America, formally The United Steel, Paper and Forestry, Rubber, Manufacturing, Energy, Allied Industrial and Service Workers International Union.

Working Families Coalition. 
Introduction

This dissertation examines the CAW's position as an agent of class formation and a vehicle for working class policies from its birth to 2010. The dissertation places particular emphasis on internal dynamics and the way these played a key role in shaping class formation within the union, focusing on the interactions between the rank-and-file delegates and leadership at CAW Council. Particular attention is focused on the CAW Council, a key institution within the union that connects rank-and-file activists to the national leadership and acts as a ground for 'mid-tier' activists to organize, pursue strategy, and push for change within the union. The dissertation uses the CAW to look at how unions can constitute themselves as class-actors. Threaded through the dissertation are questions concerning the role of union leadership, specifically how the leadership canvasses support for its strategies, how the union rank-and-file get leadership to listen to their demands, and the role of the 'mid-tier' activists at CAW in mediating both these processes. The dissertation also asks how various groups, including equity seeking groups, negotiate spaces of power within trade unions.

Until its merger with the CEP (Communication, Energy and Paperworkers), the Canadian Auto Workers (CAW, officially, the National Automobile, Aerospace, Transportation and General Workers Union of Canada), was the largest private sector union in Canada and had one of the highest profiles of all unions in Canada. ${ }^{1}$ As the largest private sector union in Canada, the CAW often had a larger profile than the Canadian Labour Congress (CLC) or provincial labour federations, placing it at the forefront of organized labour in Canada. The presidents of the

\footnotetext{
${ }^{1}$ On the 2013 Labour Day weekend the CAW merged with the CEP to form a new union, Unifor. While the creation of this new union dramatically changed organized labour in Canada, this dissertation ends its study in 2010 .
} 
CAW, especially Bob White and Buzz Hargrove, were well known political actors, with higher national recognition than other union leaders, or leaders of labour federations. Further, the CAW has long been considered part of the left-axis of trade unionism in Canada, along with the Canadian Union of Public Employees (CUPE) and the Canadian Union of Postal Workers (CUPW). The CAW also has a long history as a progressive social movement union. The profile and political orientation of the union make it an excellent case for study.

One of the key questions this dissertation addresses surrounds the CAW's apparent shift across the political spectrum. The CAW was formed when the Canadian wing of the United Auto Workers (UAW), an international union based in the United States, split to become an independent union. One of the main causes for the split was the issue of concessions at the bargaining table - the Canadian UAW was increasingly unwilling to take concessions the American wing was prepared to make. The newly formed CAW positioned itself as a "no concessions' union and placed itself broadly on the left of the political spectrum, advocating social movement unionism and supporting left wing parties as an electoral strategy. The CAW adopted the motto of 'fighting back still matters,' arguing that it was important to resist attacks by capital and the state on unions and the broader working class and could make a difference.

In contrast, in 2010, at the height of the then-current crisis of capitalism, known as The Great Recession, the CAW accepted major concessions at the bargaining table from the 'Big Three' automotive manufacturers - General Motors (GM), Chrysler, and Ford on the premise that concessions would ensure the (short-term) viability of auto manufacturing, and, thus, jobs for its members. This seemingly sudden change in strategy in fact was the result of a much more protracted and long term change as the union had slowly moved rightward in its electoral and extra-parliamentary politics. It abandoned its support of the New Democratic Party (NDP) in 
favour of a strategy of strategic voting, engaged increasingly in concessionary bargaining, and pursued a number of organizing strategies which have been heavily criticized by the broader Canadian labour movement. By looking at these examples, the dissertation examines the implications for class (de)formation in a neoliberal era.

These changes in its strategic orientation have combined with a major demographic shift within the union. When the CAW was formed, $90 \%$ of its members were in manufacturing, and almost half (42\%) worked in the automotive sector. By 2009, those numbers had declined to $45 \%$ and a mere $10 \%$ respectively. ${ }^{2}$ The CAW now represents workers in both the public and private sector, in manufacturing, wholesale, retail, and service. This has altered the CAW's internal dynamics as different groups, especially women and 'non-white' men, have sought representation within the union as a whole.

The dissertation focuses exclusively on the CAW in English-speaking Canada. The decision to focus on the CAW outside of Quebec was made for two reasons: one to do with the structure of the union and the other of methodological considerations. The Quebec region was semi-autonomous within the union, and directed itself with respect to strategy and political action. While the three table officers of the national CAW were the President, the SecretaryTreasurer, and the Quebec Director, the Quebec Director of the CAW was the de facto president of the CAW in Quebec - The Quebec Director held virtually all the powers of the national president within the province, making virtually all decisions about operations in the province. Because of this semi-autonomous nature, the Quebec region of the CAW was, in some respects, distinct from the English-CAW, and did not follow the same patterns and directions as the

\footnotetext{
2 The Canadian Auto Workers, "Building The Union in Hard Times." Documentation from the 9th CAW Constitutional Convention, 2009.
} 
English union. For example, while English-CAW supported the NDP, for a time, as national policy, the Quebec region supported the Bloc Quebecois.

In addition, while the CAW Canada Council, was a central focus of this dissertation, The CAW Quebec Council meets separately. As Savage notes, 'The CAW operates with a dual council structure. CAW Quebec Council meets separately twice a year. The dual structure was put in place to recognize the specificity of the CAW in Quebec, including the union's unique history in that province and its distinct political orientation. Historically, UAW activists in Quebec complained that the Canadian section of the union focused on southern Ontario at the expense of Quebec.' ${ }^{3}$ The Quebec Council provided a forum for Quebec members to work autonomously from the English wing of the UAW (and later CAW). While the CAW Council kept verbatim minutes of all Council meetings, which were then stored at CAW headquarters in Toronto, the Quebec Council did not keep verbatim minutes of their Council meetings, so the detailed archives, integral to this study, simply did not exist for the Quebec union. In the few instances where there were joint CAW Council - Quebec Council meetings, verbatim minutes were not kept.

\section{Previous Work on the CAW}

For the reasons suggested above the CAW has already been the object of academic study. Charlotte Yates remains the preeminent scholar on the CAW. In addition to numerous articles discussing autoworker militancy and the internal politics of the union, her book, From Plant To Politics, charts the political history of the Canadian wing of the UAW up to the moment of independence. Among other questions, Yates was interested in political formations within the

\footnotetext{
${ }^{3}$ Larry Savage, "Organized Labour and the Constitutional Question" (PhD dissertation. York University, 2006), 229, http://www.collectionscanada.gc.ca/obj/thesescanada/vol2/002/NR29523.PDF.
} 
union, and how these formations influenced the identity and class politics of the union questions that also inform this dissertation. Sam Gindin's book, The Canadian Autoworkers, studies the early history of the union, and discusses some of the early political decisions and positions. Written when he was a member of the CAW's staff, however, his book was primarily aimed at CAW members rather than a broader academic audience.

No real debates have emerged in the literature surrounding the CAW. While there are a number of disparate voices, they remain just that, without having generated a coherent set of debates in relation to which this dissertation would need to position itself. Various historians, sociologists, geographers, and political scientists have been interested in various aspects of the CAW. For example, Dimitry Anastakis has examined the interactions between the Canadian UAW and the formation of auto industry policy in the Canadian state; Don Wells has looked at the autoworkers as a case study on union formation during the postwar compromise; Stephanie Ross has explored the CAW's role in union-community coalition politics. These studies have all helped our understanding of the politics of the CAW.

This dissertation will draw critically on these different voices to make a coherent argument about the politics of class formation, deformation, and reformation in the CAW. As chapter two argues, the role trade unions play in class formation has been debated by Marxists, with unions being seen as both necessary for, and a hindrance to, class formation. The dissertation argues that the CAW or more precisely, its leadership, did work to shape a common identity and shared politics among the union membership, creating the foundations for turning the members into class-conscious actors, willing to act in solidarity with the broader working class domestically and internationally.

External factors contributed to processes of class formation within the union as well as to 
the union's approach to politics. The changing political and economic arrangements in North America, particularly neoliberal globalization, restricted the political options available to the union. These changes put considerable pressure on the union, forcing it into an increasingly defensive posture. At the same time, a change in legal-institutional frameworks, from Keynesianism to neoliberalism, shaped the way the union acted under neoliberal arrangements grew much more difficult. The relationship between the union and the NDP, Canada's social democratic party, as well as changes in the NDP's own politics, also shaped the union's strategy.

Threading through this dissertation then is the story of the move towards the political centre by the CAW. As the Canadian UAW, and in the early years of the CAW, the union was one of the most left-oriented trade unions in Canada. However, throughout its history the CAW, especially in the arena of electoral politics, tacked towards the political centre: ultimately abandoning its commitment to the NDP in order to embrace strategic voting. I argue that the external political-economic environment had a great deal to do with this shift. As the manufacturing sector declined, the union sought political solutions to support the declining sector. In part, this involved supporting the Liberal party, which the union saw as friendly to automotive capital.

From the moment the union split from the UAW, the CAW also had to deal with the challenge of plant closures - one of the realities of the neoliberal era. One of its responses was a wave of organizing new workplaces, including many outside the automotive sector. Thus throughout the 1990s the CAW moved away from being a union based primarily in automotive manufacturing to become a multisector union, with workplaces in most parts of the private sector. This made the union less homogeneous as women and ethnic minorities came to constitute a growing share of its membership. The need to incorporate these new kinds of 
workers created collective action dilemmas for the CAW. It sought to build mutual respect and solidarity by casting issues of equity as class issues as well as by working to improve things at the workplace and in Canadian society at large.

While these external factors clearly helped to shape the CAW's position, my dissertation focuses primarily on the activists at the CAW Council and the CAW leadership, and the role they played in class formation within the union. The CAW's response to the various challenges internal and external - it faced involved attempts to develop an explicitly working class identity and culture. The dissertation approaches the question of the CAW as a strategic actor by focusing primarily on dynamics internal to the union, especially as these were played out in the Council. The CAW Council, which has been described as 'the Parliament of the union,' convenes as a convention at least twice a year that brings together representatives of each local to receive updates from the national leadership and staff, to debate policy within the union, and to set overall strategy. The Council thus forms a vital link between the leadership to the rank-and-file, enabling the two to exchange information and develop strategy. The Council was an important institution within the union, especially when it came to forging responses to the challenges the union faced. The Council helped coordinate responses, set expectations, and most importantly it acted as a forum for two-way communication between the union's leadership and both the locals and rank-and-file activists. As an intermediary group the Council plays a critical role in shaping expectations and politics of the union. The debates at the Council, the extent to which they influenced the leadership and in turn, the leadership's ability to advance its agenda, played an important role in the politics of class formation. While the leadership's position and policies were firmly entrenched - the leadership has never lost a vote at council - the rank-and-file delegates have been able to influence, shape, and moderate the union's policies through the 
Council.

\section{Chapter Outline}

The first chapter develops the theoretical framework and the methodological strategy that shape the arguments in the dissertation. The chapter begins by outlining the salient features of neoliberalism as these shaped the environment within which the CAW acted. One way the CAW experienced this phenomenon was through plant closures. The chapter then goes on to discuss the theories and concepts used to understand the CAW as an organization. In particular, it draws on the works of Brodie \& Jenson and Adam Przeworski to understand the ways in which unions both help and hinder class formation. The work of Göran Theorborn is drawn on to examine processes of class deformation and reformation. From there, it looks at Offe \& Wiesenthal's propositions about collective action dilemmas in unions - in other words, on the issue of how unions grapple with the demands placed on them by an increasingly heterogeneous membership. Finally, Charles Sabel's arguments about leadership interaction with subordinates in trade unions are used to place the CAW Council in context. This leads into a discussion of the role of the Council, arguing that it provides a forum for meaningful debate and exchange between rank-andfile activists and the union leadership. At the same time it recognizes that the role of the Council has diminished over time, with the politics and policies of the union becoming more leadership centric.

The second chapter provides an overview of the history of the Canadian UAW that serves as critical historical backdrop to the main story. Looking particularly at the role of the Keynesian compromise and the transition to neoliberalism in the development of the union, the chapter outlines the factors that contributed to the eventual emergence of the CAW, emphasizing the development of a class based identity within the Canadian UAW. Particular attention is paid 
to the issues of plant closures and deindustrialization, equity within the union, and electoral politics strategies, as these will constitute the focus of the substantive chapters to come.

Chapters three, four, and five constitute the core of the dissertation. Chapter three details the union's continual fight against Free Trade agreements, focussing on the 1988 FTA. In the wake of the FTA, Canadian manufacturing, including automotive manufacturing, experienced a great wave of plant closures, concentrated in the period 1989 to 1992 . As a result, thousands of jobs were lost in the sector and with this many of its traditional core membership. In response to this challenge, the union was committed to fighting free trade. Even after the passage of the FTA, the struggle against free trade remained a defining feature of CAW political action. The union's fight-back strategy involved bargaining, organizing, and a mixture of direct political action and electoral politics. At the bargaining table the union vigorously pursued the strategy of 'no concessions,' at least until the late 2000s. Opposition to concessions at the bargaining table was central to the CAW's identity as the union was born as a rejection of the concessions accepted by its American parent. By resisting concessions, the union attempted to show its members that 'fighting back matters,' while simultaneously fostering a common culture and identity built around working class politics.

Yet even while the CAW tried to resist plant closures, its membership base shrank. As a result, the union began to devote more and more resources towards organizing new members. As the CAW began to organize outside of its traditional base, its membership base became increasingly diverse, an aspect dealt with in greater detail in chapter four. In addition to organizing new members, the CAW pursued mergers with a wide variety of smaller Canadian unions, which also increased the diversity of its membership - both in identity and in type of work. Chapter three also details the struggle around the so-called "Magna Deal," the Framework 
For Fairness, that saw the CAW enter into an agreement with auto-parts manufacturer Magna to organize new members. This deal included a no-strike pledge from the CAW, as well as radical changes to the way shop stewards were selected, and their role in the workplace. This deal was heavily criticized by the broader trade union left in Canada, and by some members within the CAW. While chapter five details the union's approach to electoral politics, this chapter reviews much of the direct action the CAW undertook to save jobs and to pursue electoral strategies. CAW members used, at different times, plant occupations, extra-parliamentary protests, and blockades against auto capital to pursue changes in the workplace and in broader Canadian society.

The demographic change brought about by organizing and mergers meant that new groups of workers, many of whom were not part of the traditional largely white male CAW base, sought representation within the union. Chapter four outlines how the CAW tried to incorporate these new voices into the union, and as part of this effort, championed equity issues within Canadian society. The Council played a particularly important role in the struggle for equity, allowing equity seeking groups to organize within the union and to bring their issues to other activists and the leadership. The leadership played a particularly important role in advancing equity issues within the union. Using symbolic bricolage, the leadership connected key equity events to the history and politics of the union. Thus for instance Bob White linked the international struggle against Apartheid to racial equity within the union, while Buzz Hargrove linked the Montreal Massacre to women's equity and the Marc Hall case to LGBTQ rights.

Chapter four thus focuses on struggles for racial equality, women's equity and LGBTQ rights within the union. Of course, equity politics within the CAW were not limited to racialized workers, women workers, and LGBTQ workers. There was a long commitment to aboriginal 
communities by the CAW, including support of first nation sovereignty and a long standing participation in the Free Leonard Peltier movement. Near the end of the CAW, there was a growing interest in youth as a social category. The chapter focuses on the three chosen groups as these were the largest and most sustained equity campaigns in the history of the union. Equity issues, for the CAW, were firmly rooted in materialist politics, and politics of solidarity with the larger working class. Expressed in these ways, it was natural for the CAW to change its internal culture, to bargain for equity based issues, and to attempt to act as an element of change in society at large.

Chapter six examines the CAW and electoral politics. From the start, the CAW was involved in electoral politics. The choices it made with relation to electoral politics were driven by two major factors. First, the CAW looked to defend union member's jobs by seeking electoral redress from the ways the union experienced the impact of neoliberalism and economic globalization, namely free trade, plant closures, and deindustrialization. Second, the CAW looked for a way to electorally advance the union's social democratic vision for Canadian society but the union underwent a slow drift from a position to the left of the NDP, to one closer to the political centre. This political shift reflected the union's attempt to protect its members' jobs in increasingly challenging circumstances.

The early politics of the CAW involved an unwavering commitment to the NDP. This was largely due to a shared commitment to social democracy in both the NDP and the union. Through the late 1980s and much of the 1990s, the CAW acted as uneasy and hesitant allies of the NDP, often acting as 'left critics' of the party. While members were occasionally urged to vote NDP, the union would frequently criticize the party for not being left wing enough. The federal election of 1988 saw the CAW, along with many other unions, rethink its position on the 
NDP. In an election dominated by the issue of free trade, the NDP did not do as much as many unions would have liked to articulate a position against free trade. In the latter years of the CAW, the union supported a strategy of strategic voting - encouraging members to vote for whatever party could defeat the Conservative party. This meant that in many ridings the union supported the Liberal party, a party which has a track record of reneging on workers' rights, but generally being supportive of automotive capital.

While sketching the union's involvement against the broad canvas of Canadian politics, the chapter is careful to note that even while keeping its eye on the federal government, the CAW's electoral actions have been very Ontario-centric. This is not to suggest that it ignored political action in other provinces, but simply that Ontario retained a central place in its political action strategies for a number of reasons. CAW density was the highest in Ontario, due partially to the auto industry's concentration in southern Ontario. Ontario's manufacturing sector has also been hardest hit by deindustrialization as was evident in the many plant closures that the union had to deal with. In addition, despite the changes it membership, the manufacturing sector in general and auto manufacturing in particular have remained central to the CAW's political strategies, Ontario is central to the union's political activities. ${ }^{4}$ The CAW thus spent a good deal of political energies lobbying the provincial government in Ontario to support the auto sector, and lobbying the federal government to support manufacturing in Ontario.

\footnotetext{
4 Jenny Ahn, in discussion with the author, June 2013; Jim Stanford, in discussion with the author, July 2013; Ken Lewenza, in discussion with the author, July 2013.
} 


\section{Introduction}

\section{Chapter One: Theoretical Framework}

This dissertation focuses on the union as a strategic actor, approaching this through an analysis of the internal dynamics of trade union power: how does the leadership get the rank and file to support its plans/strategy? How do the rank-and-file manage to get leadership to listen to their demands? How do various groups negotiate spaces of power within trade unions? Most importantly, what does this have to do with the role that unions can play as agents of class formation and class politics? These questions have been debated at great length within the Marxist tradition. The goal of this chapter is not to reprise these debates in detail but to provide the necessary theoretical interjections to understand how the CAW operates.

This chapter introduces the theoretical framework used to guide this dissertation and utlines the methodology employed. The chapter discusses the role of unions as secondary organizers of the working class, and the potential importance of unions as agents of class formation. From here, it discusses some of the nuances and challenges of class formation, before moving on to the important role that mid-tier activists, those between the rank-and-file and leadership, play in the formation of a class identity and working class politics. The chapter also discusses the role that socialist and social democratic political parties play in shaping classes and working class politics. In particular, it discusses how class alliances, a virtual necessity for social democratic party electoral success, can shape working class politics The chapter then outlines the key features of neoliberalism as these informed the challenges faced by the CAW. The chapter concludes with an outline of the methods employed, which included both archival work on the workings of the CAW Council and interviews.

Working Class Organizations: Unions \& Political Parties 
Although unions organize workers, they are not the primary organizers of workers. As Offe and Weisenthal argue, capital plays the primary role of organizing workers: workers are organized into workplaces, into specific roles at work, and capital also organizes the way their labour power is spent. Thus, trade unions act as secondary organizers of workers - organizing those that have already been organized by the capitalist labour market. Gindin goes further to argue that unions are 'sectional, not class organizations. They represent particular groups of workers confronting specific employers. ... as sectional organizations, unions are focussed on growing their own membership base, not really "organizing" these members as effective social agents, nor building the broader working class as a social force. ${ }^{1}$ As unions act as secondary and sectional organizers of the working class, a push-and-pull exists between the narrow and sectional interest of the union's members, and the broader interests of the whole working class.

In the case of the CAW, the union remained, first and foremost, an advocate for the sectional interests of the automotive manufacturing members of the union. The policies and political action of the union reflected a deep primary commitment to the union's members in the automotive sector. At the same time, however, the union often understood its interests in broader class terms. The union would frequently launch campaigns to fight back against cuts to unemployment insurance, or campaigns to protect public health care in Canada. In this sense, the union pushed for broader working class interests - however, these interests were always secondary to the sectional interests of automotive manufacturing workers.

In their role as secondary organizers of the working class, one important function of unions is to act as a counter to the power of capital in both the workplace and in the broader

\footnotetext{
${ }^{1}$ Sam Gindin, "Up Against The Wall: The Political Economy of the New Attack on the Canadian Labour Movement: A Reply to Andrew Jackson," Just Labour: A Canadian Journal of Work and Society 20 (Summer
} 
labour market. The degree and form of this counter to the power of capital depends on a number of factors, both exogenous and internal to trade unions. While the Marxist analysis holds that one's class position is determined by one's relationship to the means of production, selling one's labour power for a wage does not immediately imbue a worker with class consciousness. As Przeworski notes, class formation is itself a process which involves heightening levels of consciousness so that the working class becomes organized as a political unit and acts with a consciousness of working class solidarity. ${ }^{2}$ Classes, as political units, do not appear spontaneously - 'they must be formed, and only with such class formation will they be active and self-conscious social actors. ${ }^{3}$ In their function countering the power of capital, unions can contribute to heightening levels of class consciousness, which contributes to the process of class formation.

Therborn argues that 'capacities of a given class to act in relation to others' are 'typically more interesting than states of consciousness. ${ }^{4}$ Expanding on this, Therborn argues that there is an objective aspect to class formation - 'a socio-economic process accompanying the development of a mode of production: the process of agents moving into, being shaped by, and being distributed between the different kinds of economic practices which constitute the given mode of production,' as well as a subjective aspect - 'an ideological and political process of the tendential unification of class members into forms of common identity and of concerted action as

2013): 65 .

${ }^{2}$ Adam Przeworski, "Proletariat into a Class: The Process of Class Formation from Karl Kautsky's The Class Struggle to Recent Controversies," Politics \& Society 7, no. 4 (December 1977). See especially pages 348 349 .

${ }^{3}$ Janine Brodie \& Jane Jenson, Crisis, Challenge, and Change: Party and Class in Canada Revisited (Ottawa: Carleton University Press, 1991), 11.

${ }^{4}$ Göran Therborn, "Why Some Classes Are More Successful Than Others," New Left Review 138 (MarchApril 1983): 38 . 
conscious class members. ${ }^{5}$ The CAW certainly experienced different waves of the subjective forms of class formation, as new members, with new identities, were organized into the union. Further, the changing political and economic environment, specifically the solidification of neoliberalism in Canada, saw different objective conditions that structured the way class formation took place in the CAW

Therborn goes on to argue that class formation is not the only process involved in class consciousness. Beyond class formation, classes can have moments of de-forming and possible moments of re-forming. ${ }^{6}$ This suggests that class formation is not a unidirectional process, nor that once a class is formed will it remain formed; indeed, the process of class formation can be rife with contradictory moments of class formation, deformation, and reformation. As we will see, the CAW experienced aspects of class deformation. Taking concessions at the bargaining table, the shift to strategic voting, and a move away from dialogical discussion within the union, towards one dominated by the leadership, are all indications of moments of class deformation class consciousness being stunted. The CAW also experienced moments of class reformation, especially around the union enriching the concept of class through the inclusion of gender, raceethnicity, and sexuality in their definition of class. Here, the new waves of subjective class formation within the CAW contributed to moments of class reformation.

Sabel highlighted the importance of internal union organization to class formation, in particular the interaction of mid-tier activists and leadership. In the CAW, 'mid-tier' activists were found at the Council: the intermediaries between the union's national leadership and the workers on the plant floor. The presence of the CAW Council allowed for interactions between

\footnotetext{
${ }^{5}$ Ibid, 39.

${ }^{6}$ Ibid.
} 
the rank-and-file and the leadership to produce modified policy. Discontent from the rank-andfile could be pushed upward, while the leadership simultaneously pushed back. As a result, policy was crafted that was often not the optimal outcome for the rank-and-file, but certainly had some elements of the wishes of the membership base. At the same time, most of the policies the leadership wanted did come to fruition, albeit modified, frequently only slightly so, by the rankand-file. Offe and Weisenthal rightfully point out that capitalist and labour organization have different patterns of communication: capitalist organizations communicate monologically (ie, there is one-way communication between employers and workers), while trade unions must communicate dialogically (there is two-way communication between union leadership and the rank-and-file); the dialogical forms of communication are helpful to the process of class formation as they help to "overcome the diversity of interests represented by the union. ${ }^{7}$ The CAW saw dialogical communication between the leadership and mid-tier activists take place at the CAW Council, the central forum for the union.

Sabel also discusses the dilemma of using subordinates without ceding substantial power to them. To do this, Sabel suggests that:

'Ideally, union leaders would like to construct an organization that would, first, efficiently collect and pass upward accurate information about the members' desires. In this way the leadership would never be in the dark as to their members' definition of the minimally acceptable settlement. ... Second, the organization would work on two levels at shaping the members' expectations of the union. More abstractly, the union will teach the related lessons of class antagonism and the need for a permanent, organized defense. ... On the more concrete, day-to-day level, the organization would aim at convincing the members that the leadership is pursuing the correct strategy., ${ }^{8}$

\footnotetext{
${ }^{7}$ Clus Offe \& Helmut Wiesenthal, "Two Logics of Collective Action: Theoretical Notes on Social Class and Organizational Form," Political Power and Social Theory 1, (1980): 93.

${ }^{8}$ Charles Sabel, "The internal politics of trade unions" in Organizing Interests in Western Europe, edited by Suzanne Berger (Cambridge: Cambridge University Press, 1093), 228.
} 
As we shall see, the CAW Council nicely reflects this thesis. Sabel also argues that 'if leaders want to hold on to their offices and influence they will be forced constantly to make deals and enter debates with one another, their subordinates, and their followers. ${ }^{9}$ As we shall see, the Council provided such a forum for debate and dialogical discussion. Indeed, one of the main purposes of Council was to allow the rank-and-file to engage with the leadership. Thus the main forum for the passing of information down to subordinates and back up to the leadership and the molding of organization policy and doctrine was the CAW Council.

Michels was similarly interested with internal dynamics of organizations, especially with the tendency towards oligarchy in organizations such as trade unions. Arguing that in trade unions, the conduct of negotiations and strikes required an organization led by officials with specialised experience and knowledge, there would be a need for a bureaucratic leadership. ${ }^{10}$ Following this, 'the formation of oligarchies within the various forms of democracy is the outcome of organic necessity, and consequently affects every organization, be it socialist or even anarchist. ${ }^{11}$ Michels goes on to argue that situations can arise where the interests of the bureaucracy contradict the interests of the body of the membership - the bureaucracy may hold conservative interests, while the interests of the membership may be 'bold and aggressive. ${ }^{12}$ This is closely related to Sabel's idea that leadership will use subordinates without ceding power to them. As we will see in the CAW, at times the leadership was less open to dialogue and more manipulative of CAW Council, often as the union faced increasing external pressure from deindustrialization and neoliberal government.

\footnotetext{
${ }^{9}$ Ibid, 230.

${ }^{10}$ Richard Hyman, Marxism and the Sociology of Trade Unions, (London: Pluto Pamphlets, 1971), 15.

${ }^{11}$ Robert Michels, Political Parties: A Sociological Study of the Oligarchical Tendencies of Modern Democracy, trans. and ed. Eden and Cedar Paul (Kitchener: Batoche Books, 2001), 241.
} 
The oligarchic tendencies of organizations allow, in many ways, for those organizations to survive. Bureaucratic leadership develops leaders and a bureaucracy possessing considerable skill and expertise and because of this, it become more difficult to challenge. However, this grants an institutional memory to the organization which allows it to succeed.

The process of forming a class identity can be both challenged and enriched by the presence of other key identities in the working class, notably gender, race, and ethnicity. Many industrial and manufacturing trade unions in Canada began with a base of mostly white, mostly male members. Most of these unions, however, have organized outside of this base. The impetus can come from an ideological commitment to organizing, or from the necessity of attracting new members as a matter of survival, or a combination of the two. Such expansion, however, can lead to a dilemma: for Offe \& Wiesenthal, there is an optimum size, beyond which union power decreases. This decrease in union power stems from the fact that as 'union size increases, heterogeneity of members' positions, occupations, and immediate interests tends to increase, too, which makes it more difficult to formulate generally agreed upon demands. ${ }^{13}$ Most industrial unions, in the North American context, had a specific sector they initially organized in, and this provided for an easy scope of demands for the union. As unions expand beyond this initial sector, they become more heterogeneous, making the demands of the union more disparate. At the same time, this expansion can see a host of new identities organized into the union. Thus one of the challenges facing unions is 'the task of organizing the entire spectrum of needs that people have when they are employed as wage workers, ${ }^{14}$ not simply monetary and other material rewards - these needs would include needs specific to certain identities not

\footnotetext{
${ }^{12}$ Ibid, 222.

${ }^{13}$ Offe \& Wiesenthal, "Two Logics of Collective Action," 81. Emphasis in the original.
} 
reducible to class. This becomes problematic if the other identities are privileged at the expense - rather than as an integral part - of class identity. In the case of the CAW, as we shall see, the identity of the autoworker remained central, and privileged to the CAW. This sectoral interest was at the centre of the, increasingly heterogeneous, union's politics and policies, privileged much more than any other sectoral identity. At the same time, the union was also more heterogeneous around non-sectoral identities: the union became increasingly less white and less male. In this form of heterogeneity, the union made great attempts to not privilege one identity over others. Przeworski argues that highlighting other bases of collective identity, such as religion, language, region, sex, and race, may have the effect of reinforcing a classless image of society, which decreases the salience of class as the basis for collective action. ${ }^{15}$

Michels highlighted similar concerns about the growth of the size of organizations. For Michels, 'as the organization increases in size, the struggle for great principles becomes impossible. ... the efforts made to cover internal dissensions ... are the inevitable outcome of organization based upon bureaucratic principles. ${ }^{16}$ As unions increase in size, there becomes a greater chance of internal dissensions over principles within the organization, and the bureaucracy becomes seized with avoiding these internal dissensions, and becomes more oligarchic in nature. Thus 'union leadership is constantly caught between attempting to provide comprehensive representation for all the interests of its working class constituency and being limited in its ability to find a formula that reconciles ${ }^{17}$ diverse interests.

The union can face the challenge of mobilizing a diverse membership behind a cohesive

${ }^{14}$ Ibid 75.

${ }^{15}$ Przeworski, "Proletariat into a Class," 383.

${ }^{16}$ Michels, Political Parties, 219.

${ }^{17}$ Offe \& Wiesenthal, "Two Logics of Collective Action," 83. 
set of goals, with a united course of action for all members, which can contribute to class reformation. As we shall see, as the CAW organized new workers outside the union's traditional core of auto and auto parts manufacturing, the union became more heterogeneous. As a result the union ceased to be predominantly white and male. This left the union in a position where it had to deal with demands for representation from new groups within the ranks. One way for a union to mobilize members is to 'form a collective strategy of conflict which not only aggregates the individual resources of the members of the association in order to meet the common interests of these individuals, but which also overcomes the individuality of those resources and interests. ${ }^{\text {18 }}$ As we shall see, the CAW's strategy was centred around a collective working class identity built on the strategies of no concessions at the bargaining table and the idea that fighting back still matters. This class identity, enriched by the incorporation of race, gender and sexuality, helped build a much stronger union where various identities were linked together to forge a common working-class identity to fight for gains for all members - a very strong moment of class reformation within the CAW.

When dealing with issues of equity, CAW presidents often employed symbolic bricolage to link key equity events to the history and politics of the union. John Campbell, drawing on the work of Mary Douglas, has shown that actors self-consciously craft solutions to their problems through a process of bricolage, through which they recombine already available and legitimate concepts, scripts, models, and other cultural artefacts found in their institutional environment. In this view, change results from the deliberate modification and recombination of old institutional elements in new and socially acceptable ways. ${ }^{19}$ Bricolage thus occurs when actors self-

\footnotetext{
18 Ibid, 78.

19 John L. Campbell, "Institutional analysis and the role of ideas in political economy," Theory and Society
} 
consciously devise solutions to their problems by deliberately manipulating explicit, culturally given concepts that reside in the cognitive foreground. ${ }^{20}$ In this case, the leadership attached an issue to a concern already present in the union, a principal or part of the CAW's culture that the membership fully embraced. Symbolic bricolage was frequently used dialogically in the communication at the Council to link cultural practises in the CAW - for example, the union's fight against Apartheid in South Africa - to larger political questions (here the fight against racism). The two-way communication at Council allowed union leadership to link key parts of the union's identity to larger political struggles, and allowed the mid-tier activists at Council to help develop strategies and policies to link in with these larger political struggles. While this mainly occurred around questions of identity, it was also present when the union leadership was interested in larger questions of working class politics; for example, the struggle for better wages in the CAW was linked to a more robust unemployment insurance system in Canada.

Questions of identity within trade unions can play out around the relationship between leaders, the rank-and-file, and especially 'mid-tier' activists located between the leadership and the membership base. Drawing on the works of Fairbrother and Hyman, Martinez Lucio opens internal trade union dynamics up to account for gender issues alongside economic issues, which is of particular importance to the study of the CAW. Unions in the modern context, grappling with a more heterogeneous membership must 'address issues of accountability and not just control. ${ }^{21}$ Indeed, as we shall see the very raison d'etre of the CAW Council was to allow the rank-and-file to make the leadership accountable, at least in theory. Further, for Lucio,

27 (1998): 383.

${ }^{20}$ Ibid.

${ }^{21}$ Martinez Lucio, "Union politics, purpose and democracy: To be or not to be? Optimism, pessimism and the continuing importance of Richard Hyman's early contributions," Capital \& Class 36, no 1 (2012): 43. 
'democracy and rules are a significant space and vector for the interplay of union politics and debates. They are spaces and traditions that are open to contestation. ${ }^{22}$ By extension, the degree and form that democracy takes within the structures of a union will have a dramatic effect on the type of class politics formed within the union. Darlington and Upchurch argue that 'a good deal of permanent power tends to rest with those who hold the highest official positions, who are in a position to override policy decisions taken at democratic national conferences of membership representatives. ${ }^{23}$ With regard to the CAW, its Council played a role which mediated the political stance of the leadership vis-à-vis the rank-and-file. Although the union leadership frequently "got its way," it could not simply 'override' the decisions of the rank-andfile - it needed to negotiate politically with the latter.

While unions can, and do, contribute to the development of class consciousness, working class political parties are another agent of class formation. Socialist and social democratic parties have had historical roots in the industrial working class, and have acted as a challenge to bourgeois political parties; in this way, they act as an agent of class formation. Early socialist and social democratic parties had clear ties to the industrial working classes of their respective nations, and were part of 'the much broader process of the making of the Western working classes, which also included the development of trade unions and a distinct working-class culture. ${ }^{24}$ Social democratic parties had a clear role in articulating the political demands of the working class as class demands and acting as a collective challenge to bourgeois parliamentary politics. In order to act as effective agents of class formation, 'social democratic parties and

\footnotetext{
${ }^{22}$ Ibid.

${ }^{23}$ Ralph Darlington \& Martin Upchurch, "A reappraisal of the rank-and-file versus bureaucracy debate," Capital \& Class 36, no 1 (2011): 84.

${ }^{24}$ Ingo Schmidt, "It's The Economy Stupid! Theoretical Reflections on Third Way Social Democracy," in Social Democracy After The Cold War, edited by Bryan Evans \& Ingo Schmidt, (Edmonton: Athabasca University
} 
labour movements must broadly represent the same groups of people, and they must have something concrete to offer each other beyond shared cultural traditions. ${ }^{25}$ The traditional bargain has been that labour movements will 'offer' voters and material support to social democratic parties which will, in turn, offer policies favourable to organized labour if they form government. 'Those two bargains were both strengthened in the period 1945-75 when the overlap of interests between social democratic parties and union movements was high. ${ }^{26}$

Przeworski argues that in the process of transition from what Marx called class-in-itself to a class-for-itself, that 'classes are formed in the course of struggles; that these struggles are structured by economic, political, and ideological conditions under which they take place, and that these objective conditions mold the practice of the movements that seek to organize workers into a class. ${ }^{27}$ This suggests that the broader context and the leadership's capacity to forge an adequate response thereto matters a great deal in the process of class formation. Przeworski grapples specifically with the question of electoral politics and class formation, noting that the decision to participate in bourgeois politics, or not, has continually divided working class movements. ${ }^{28}$ While some may see parliamentary battles as "parliamentary cretinism" or simply bourgeois politics, Przeworski rightly notes that 'precisely because workers are exploited as immediate producers and precisely because elections are within limits instrumental toward the satisfaction of their short term material interest, all socialist parties either enter into electoral struggles or lose supporters. ${ }^{29}$

Press, 2012), 27.

${ }^{25}$ Chris Howell, "The End Of the Relationship Between Social Democratic Parties and Trade Unions?," Studies in Political Economy 65 (Summer 2001): 31.

${ }^{26}$ Ibid.

${ }^{27}$ Przeworski, "Proletariat into a Class," 370.

${ }^{28}$ Ibid, 379.

${ }^{29}$ Ibid. 
A tension grows here, however. As organizations of the working class chose to participate in electoral politics as part of a broader working class politics, socialist parties must 'appeal to members of other classes as they organize workers into a class. ${ }^{30}$ Hence, for Przeworski, participating electoral politics is both a necessary and a limiting factor in the process of class formation. More specifically, Sheri Berman argues that 'the idea of building cross-class support for social democratic parties failed during times of world wars and depressions. ... During the postwar prosperity, programmatic commitments to the working class and a gradual transformation toward socialism ... were abandoned in the early years of the postwar boom. From then on, social democratic organizations presented themselves to the electorate as "people's parties." 31 Bryan Evans concurs, noting that while social democracy had its original ideological roots in broad Marxism and a political base in the urban working class, in the postwar era, 'this heritage was largely jettisoned and replaced with a form of progressive Keynesianism and an increasingly heterodox political base that included a growing number of professionals.' ${ }^{32}$ EspingAndersen has a more optimistic outlook regarding class alliances. Studying Nordic social democracy, Esping-Andersen shows how the social democratic parties in the Nordic states 'in the 1960 s recast their image as wage-earners parties, in order to align with the new middle strata.' 33 By casting themselves as a party of 'wage earners,' especially around the issue of pension reform - which held salience both with the traditional working class and the growing white collar middle strata - the Swedish social democrats were able to build a cross-class

${ }^{30}$ Ibid, 380.

${ }^{31}$ Ingo Schmidt, "It's The Economy Stupid," 21.

32 Bryan Evans, "The New Social Democracy" in Social Democracy After The Cold War, edited by Bryan Evans \& Ingo Schmidt, (Edmonton: Athabasca University Press, 2012), 1.

${ }^{33}$ Gosta Esping-Andersen, Politics Against Markets (Princeton: Princeton University Press, 1985), 89. 
alliance centred on wage solidarity between these two classes. ${ }^{34}$

The relationship between class, unions, and political parties has been of interest to other thinkers. In much of the industrialized democratic world labour parties developed to provide parliamentary representation to the union movement. Brodie and Jenson argue that the linkages between political parties and trade unions are, in part, determined by the political position of the union themselves. For these authors, 'trade unions have been particularly important in the creation and support of left-wing parties because they often were the first bodies which began to organize workers as a class and to provide an alternative interpretation of capitalism. ${ }^{35}$ The willingness of trade unions to participate in electoral politics with political parties depends on the class politics of the union. If 'the existence and characteristics of class conflict are exposed by the activities of a well-developed trade-union movement ... then there should be evidence, at the level of voting, of class-based politics. ${ }^{36}$ However, if the trade union movement defines politics in such a way that capitalist social relations are resolvable in the workplace, without participating in electoral politics, then parties of the left end up competing with unions for the support of workers. ${ }^{37}$

In Western Europe, especially in Sweden and England, close relationships developed between the labour movement and social democratic parties. In Canada, the CCF, the forerunner to the NDP, developed as a socialist, but not explicitly labour, party in the 1930s but the transition to the NDP in the 1960s saw the party become 'the political wing of organized labour.' Drawing on a view of class politics very similar to Przeworski's, Brodie and Jenson investigated

\footnotetext{
${ }^{34}$ Ibid, 109.

${ }^{35}$ Brodie \& Jenson, Crisis, Challenge, and Change, 14.

${ }^{36}$ Ibid, 12.

${ }^{37}$ Ibid.
} 
the comparatively late development of a working class party in Canada, arguing that throughout the history of the Canadian party system, the two major parties - The Liberals and the (Progressive) Conservatives - have successfully hindered the formation of working class parties. ${ }^{38}$ These parties have cast electoral politics along a definition of politics which stresses the importance of 'social diversity of Canada resulting from the existence of two separate cultures within a single state,' arguing that consensus amongst cultural diversity is the main cleavage, not class politics. ${ }^{39}$

Some social democratic parties were founded on successful class alliances. For example, Esping-Anderson highlights in the formative years of Nordic social democracy, social democratic parties organized alliances between liberal farmers and socialist workers. This alliance allowed for an early struggle for democracy, and later served to divide the bourgeois parliamentary bloc, providing relative strength to the social democratic parties. ${ }^{40}$ In Canada's case, social democracy started out as a multi-class project, and the cross-class nature of social democracy was amplified during the Keynesian era when 'the CLC adopted a resolution calling for the creation of a new political party 'which embraces the CCF, the Labour movement, farm organizations, professional people and other liberally minded people. ${ }^{41}$

This suggests that there is no natural relationship between social structure and voting behaviour: political parties have ended up competing for votes from all classes and social strata. Like Przeworski, Brodie and Jenson argue that the working class will not spontaneously recognize the political implications of its class location in capitalism and then vote according to

${ }^{38}$ Brodie \& Jenson, Crisis, Challenge, and Change, 2

${ }^{39}$ Ibid.

${ }^{40}$ Esping-Andersen, Politics Against Markets, 71 -73.

${ }^{41}$ Bryan Evans, "From Protest Movement to Neoliberal Management: Canada's New Democratic Pary in the Era of Permanent Austerity," in Social Democracy After the Cold War, edited by Bryan Evans \& Ingo Schmidt, 
this position: class-based voting has a necessary precursor in the 'development of a class based organization which challenges hegemonic definitions of politics that interpret social and political relations in non-class terms. ${ }^{42}$ For them, trade unions are one of these class based organizations that can contribute to an alternate definition of politics, and, eventually build towards class-based voting in electoral politics.

\section{Neoliberalism}

Neoliberalism constituted the dominant ideological, political, and economic framework for the entirety of the CAW's existence as an independent Canadian union. Neoliberalism is an ideology and a set of policies and practises, which emerged out of the crisis of the Keynesian national welfare state. During the neoliberal era, unions face an ideological and economic attack from both capital and the state. Neoliberal ideology highlights the importance of individual rather than collective action, which makes it harder to organize workers into a class. Moreover the central underpinnings of neoliberalism question unions' position within society. Whereas under Keynesianism at least, unions had a positive role to play, neoliberal tenets suggest that unions raise the cost of production and introduce rigidities into the work process and the labour market. Hence the rise of neoliberalism presented very real problems for the CAW's politics and strategy. Neoliberalism narrowed what could be achieved during collective bargaining, shaped the relationship between the union and electoral politics, and affected the way class formation and identity was undertaken within the union.

As noted above, the Keynesian era was built around a class compromise whereby capital would provide higher wages to workers, while the state would provide a social safety net In 
return, labour would remain relatively peaceful, which would lead to high levels of uninterrupted accumulation for capital. Keynesianism also coincided with the Fordist regime of accumulation, which included the major elements of 'the dominance of mass production (economies of scale, assembly-line production, detailed division of labour, separation of execution and control at the workplace), balanced by high levels of mass consumption, maintained by institutional supports which included demand policies. ${ }^{43}$ In this context, the union's efforts to boost wages and secure insurance against risks of unemployment, illness or injury supported the dominant economic model.

During the construction of the Keynesian Welfare State the connection between the labour movement and social democratic political parties was particularly strong. Howell argues that 'close ties between union movements and social democratic parties rest upon a shared set of interests, mediated through a shared ideology. The nature of those ties can be clearest and closest when both union and party share a commitment to the broad transformation of capitalism. ${ }^{44}$ In the Canadian context, Brodie and Jenson argue that both 'the CCF leadership and CCF militants within the unions continued to attempt to forge formal ties between the unions and the CCF. The goal was to bring the unions into a relationship similar to that in the United Kingdom, where unions were directly affiliated with the labour party. ${ }^{45}$ The CCF was initially positioned to the left of organized labour, and as a result the party 'was pressured into moderation and a great deal of emphasis on immediate benefits, in order to build the long-desired coalition. For these reasons, the programmes that the CCF advocated were almost the same as those put forward by

\footnotetext{
${ }^{43}$ Stephen McBride \& John Shields, Dismantling a Nation: The Transition to Corporate Rule in Canada, Second Edition, (Halifax: Fernwood Publishing, 1997), 37.

${ }^{44}$ Howell, "The End Of the Relationship": 13.

${ }^{45}$ Brodie \& Jenson, Crisis, Challenge, \& Change, 203.
} 
the two bourgeois parties, ${ }^{46}$ namely, a robust Keynesian welfare state, rather than the abolition of capitalism.

Reflecting on Keynesianism in the Canadian context, McBride and Shields outline four pillars of the Keynesian economic order: the state's respect of the key interests of capital, policies ensuring high and stable levels of employment and income, a social welfare state, and an explicit commitment to the rights of trade unions. ${ }^{47}$ During the Keynesian era, social democratic parties cast themselves as defenders and expanders of the Keynesian Welfare State. In doing so, many moved away from their traditional roots in class-based politics. In Canada, the NDP was no exception. The transition to the NDP from the CCF in 1961 saw 'a declassed and technocratic Keynesianism that signalled a retreat from class as an ideological organizational centrepiece of its politics. The construction of the NDP was, from its inception, an adaptation to the economic conditions of the golden age of postwar North American capitalism. ${ }^{48}$ Social democracy, including the NDP in Canada, soon became synonymous with the Keynesian Welfare State.

The Keynesian era did see both unions and social democratic parties sharing a commitment to the transformation of capitalism along the broad contours of Keynesian economic management. Howell goes on to show that the class structure present in the Keynesian era 'encouraged the overlap between union and Left party constituencies, and the relative cohesion of those constituencies. ${ }^{49}$ Such cohesion was due, in part, to a shared ideological commitment to the welfare state. During the Keynesian era social democratic parties developed close ties to

\footnotetext{
${ }^{46}$ Ibid, 204.

47 Ibid, 40.

${ }^{48}$ Evans, "From Protest Movement to Neoliberal Management," 45.

${ }^{49}$ Howell, "The End Of the Relationship:" 15.
} 
labour movements. However, in order to effectively win elections and form office, social democratic parties looked for electoral allies outside their traditional base in the industrial working class, especially in the emerging 'new middle class' of white-collared professionals. This development has two potential outcomes. First, it can lead to the strain that Przeworski astutely noted: as social democratic parties looked for electoral allies, their class base becomes diluted. Conversely, it can take the path outlined by Esping-Andersen's analysis of the Swedish LO and SAP, where social democratic parties can link multiple classes together around a common identity of the 'wage earner.'

As Jessop notes, the Keynesian Welfare State 'was a key structural support of the long postwar boom; and that it has since entered into crisis along with its associated accumulation regime. ${ }^{50}$ In the late 1960 s and early 1970 s rising levels of inflation coupled with stagnating economic growth ('stagflation'), the OPEC oil shocks, and a declining global rate of profits all undermined the basis for Keynesianism. It was these internal crises and contradictions of Keynesianism and Fordism that initially opened the way to neoliberalism. Neoliberalism involved an explicit political attack on the Keynesian welfare state, which capital began to see as a barrier to high levels of accumulation. The neoliberal alternative to Keynesianism meant a restructuring of capitalism to 'provide a means by which capital could begin to disengage from many of the positions and commitments which had been taken up during the Keynesian era. ${ }^{51}$

The crisis of the Keynesian welfare state and the ascendancy of neoliberalism saw changes to the class base of social democratic parties. The problem of inflation, one of the factors that led to the decline of the Keynesian welfare state, challenged the electoral base of

\footnotetext{
${ }^{50}$ Bob Jessop, "Towards a Schumpeterian Workfare State? Preliminary Remarks on Post-Fordist Political Economy.” Studies in Political Economy 40 (Spring 1993): 9.
} 
social democratic parties. As Schmidt argues, 'rich and affluent middle-class households saw it as a threat to their financial wealth, while poor people struggled with the decreasing purchasing power of their low wages. These frustrations were successfully mobilized against the wage bargain that allowed unionized workers to defend, or even increase, their real wages against inflation.' ${ }^{52}$ In the neoliberal era, working class voters began to abandon social democratic parties out of frustration, voting for electoral competitors of the "new" left, green parties, or in some cases, the radical right. Social democratic parties, having built an identity as staunch defenders of the welfare state during the Keynesian era, began to find themselves adrift after the collapse of Keynesianism. This, in turn, led many of these parties to incorporate neoliberal ideas. Social democracy thus went through a sea change in the neoliberal era, emerging in a new form, 'sometimes referred to as the Third Way, that is committed to globalization, expanding economic competition, the role of the market economy and accepting of greater levels of economic inequality. ... Third way social democracy was an adaptation of social democracy to neoliberalism's hegemonic position rather than an alternative to it. ${ }^{53}$

The demise of the Keynesian Welfare State thus had profound effects on social democratic parties. Where these parties adapted to the conditions of the Keynesian era, often becoming defenders of the welfare state and shedding some radical demands, the neoliberal era saw a further deradicalization of parties of the left. Evans argues that these parties quickly adapted to neoliberalism: 'neoliberalism ... has been such a powerful force since the early 1980s that social democracy, ever adaptable and protean, has transformed to accommodate itself to the

\footnotetext{
${ }^{51}$ Ibid, 131.

52 Ingo Schmidt, "It's The Economy Stupid," 32.

${ }^{53}$ Bryan Evans, "The New Democratic Party in the Era of Neoliberalism," in Rethinking the Politics of Labour In Canada, edited by Stephanie Ross \& Larry Savage (Halifax: Fernwood Publishing, 2012), 48.
} 
new conditions created by neoliberalism's rise. ${ }^{54}$ Gerassimos Moschonas concurs, arguing that, the neoliberalization of social democracy had two major effects. First, 'social democratic parties successively embarked on a process of doctrinal and programmatic deradicalization, constituting themselves as parties of "all the people" rather than parties with an explicit class base. ${ }^{55}$ Second, 'a ubiquitous and progressive loosening of the links between socialist parties and trade unions is currently in progress. ${ }^{56}$

As neoliberalism became a hegemonic political and economic ideology during the 1970s, Savage argues 'most social democratic parties shifted to the political center, jettisoning key components of the social democratic project of full employment and welfare state expansion. This significant political and economic shift, which in effect stripped unions of their traditional political clout, led to a re-evaluation of the traditional link between organized labor and social democratic parties in all advanced capitalist countries. ${ }^{, 57}$ Howell agrees with these concerns, arguing that 'Social democratic parties now display a disarming enthusiasm for economic orthodoxy emphasizing neo-liberalism, macroeconomic stability, labour market flexibility, and a shrinking role for organized labour in political economy of the Left. ${ }^{58}$

After the collapse of Keynesianism, many social democratic parties failed to present a coherent and programmatic challenge to neoliberalism. This raises serious questions about the role of social democratic parties as agents of class formation during the neoliberal era. If social democratic parties have become little more than "neoliberal lite" parties, can they still act as agents of working class formation? If neoliberalism is to be understood as a project of the

\footnotetext{
${ }^{54}$ Evans, "From Protest Movement to Neoliberal Management," 47.

${ }^{55}$ Gerassimos Moschonas, In The Name of Social Democracy. The Great Transformation: 1945 to the Present, trans. and ed. Gregory Elliot (London: Verso, 2002), 49.

56 Ibid, 132.

${ }^{57}$ Larry Savage, “Contemporary Party-Union Relations in Canada,” Labor Studies Journal 35 (2010): 9.
} 
capitalist class, it is reasonable to suggest that these parties do not have the capabilities to successfully act as vehicles for working class parties.

This, in turn, creates an electoral dilemma for the labour movement: abandoned by, or themselves abandoning, their traditional electoral allies, the labour movement has no clear electoral vehicle to cooperate with. Upchurch, Taylor, and Mathers argue that

'neoliberal restructuring presents trade unions with three principal avenues of strategic and ideological orientation. First, unions may adopt collaborationist strategies designed to appeal to business competitiveness. Second, unions may seek to lobby the party of labour for a return to traditional social democracy. Third, unions can liberate themselves from the institutional and ideological fetters of Keynesianism in order to re-establish themselves as movements'. ${ }^{59}$

As chapter five details, at various times the CAW has embraced all three of these strategies. In the mid-to-late 1990s, the CAW worked to encourage the NDP to return to a form of traditional, labour friendly, social democracy, working to 'change the NDP from within'. Even when CAW mistrust of the NDP was high, the union was confident that sending union members to party conventions, or having union members run for the party, would lead to a greater chance of the union being able to pull the party back to the left.

Drawing on Przeworski's dilemma of class-based parties, Evans suggests that the electoral success of social democratic parties under neoliberalism could only be achieved through multi-class alliances, won at the cost of further diluting the working class base in the party - a base which in most cases had involved other multi-class alliances before the neoliberal era. ${ }^{60}$ Moschonas summarizes social democracy in the neoliberal era as

\footnotetext{
${ }^{58}$ Howell, "The End Of the Relationship": 33.

${ }^{59}$ Martin Upchurch, Graham Taylor, and Andrew Mathers, The Crisis of Social Democratic Trade Unionism in Western Europe: The Search for Alternatives, (Surrey: Ashgate, 2009), 15.

${ }^{60}$ Evans, "From Protest Movement to Neoliberal Management," 60.
} 
'the adoption of a moderate neoliberal discourse, supplemented in some cases by a moderately expressed post-materialist sensibility ... The new social democracy is a more moderate force programmatically and ideologically than ever: moderately neoliberal, moderately non-liberal, moderately ecological and postmaterialist, and sometimes moderately law-and-order. ${ }^{\text {, }}$

Evans argues that during the neoliberal era the NDP 'would drift and seek to adapt to, rather than critically assess and challenge, the changing terrain of capitalism. ${ }^{62}$ Practically, 'the political practise of New Democratic governments through the 1990s to the present demonstrates the unambiguous success of neoliberalism in disorganizing the working class' unions and political parties. It is now virtually impossible to discern what sets an NDP government apart from the traditional parties of business. ${ }^{63}$ Ross \& Savage echo this assessment, arguing 'when in power, parties linked to the labour movement have increasingly abandoned the agenda of economic and social equality that brought them to power.' ${ }^{64}$ Social democracy in English-speaking Canada, embodied in the NDP, has not articulated a clear working class political alternative to neoliberalism; rather, it has embraced many of the key parts of neoliberalism and has become ever increasingly ideologically indistinguishable from the traditional Canadian bourgeois parties. To this end there is no political party in Canada that can act as an agent of working class formation; indeed, considering the roots of the NDP were found in a multi-class arrangement, there has even been an historical lack of a strong working class party in Canada. ${ }^{65}$

${ }^{61}$ Moschonas, In The Name of Social Democracy, 231.

62 Ibid, 58.

${ }^{63}$ Ibid, 94.

${ }^{64}$ Stephanie Ross \& Larry Savage, "Rethinking the Politics of Labour in Canada: An Introduction," in Rethinking the Politics of Labour In Canada, edited by Stephanie Ross \& Larry Savage (Halifax: Fernwood Publishing), 8 .

${ }^{65}$ Social democratic parties that start as parties of class alliances are not doomed to fail as advocates of working class politics. As Esping-Andersen shows, the early alliance between the farmers and labour in Sweden developed into a strong electoral coalition. The CCF started as an agrarian-labour party, but the NDP never developed a strong class alliance that was present in the SAP in Sweden in the post-war years. While the SAP developed into a party of 'wage earners,' the NDP did not take on a class identity, instead becoming a party 'for the people.' 
In broad terms neoliberalism has operated to restore power to the capitalist class - power that was diminished somewhat during the 'post war compromise.' As McBride argues, 'neoliberalism involved political action aimed at reducing or removing impediments to market forces, including global market forces. ${ }^{66}$ The transition to neoliberalism and the intensification of economic globalization have involved intense state restructuring of local, national, and international markets to allow for greater capitalist accumulation. One of the major successes of neoliberalism has been to redistribute wealth upwards, transferring wealth from the working class to the bourgeoisie. Thomas Piketty has shown concretely that 'since the 1970s, income inequality has increased significantly in the rich countries,' and 'the inequality after 1980 is due largely to the political shifts of the past several decades, especially in regard to taxation and finance. ${ }^{67}$

One policy aspect of neoliberalism involves an intensification of economic globalization. The state is not a neutral actor in the accelerated internationalisation of production as, for Jessop, the state manages 'the national economy's insertion into the global economy in the hope of securing some net benefit from internationalization.' ${ }^{68}$ Neoliberalism, economic globalization, and post-Fordism are all interrelated. ${ }^{69}$ The neoliberal era has been characterized by an

\footnotetext{
${ }^{66}$ Stephen McBride, Paradigm Shift: Globalization and the Canadian State, 2nd Edition, (Halifax: Fernwood Publishing, 2005), 99.

${ }^{67}$ Thomas Piketty, Capital in the Twenty-First Century, trans. Arthur Goldhammer (Cambridge, Massachussets: The Belknap Press of Harvard University Press, 2014), 15, 20.

${ }^{68}$ Jessop "Towards a Schumpeterian Workfare State?," 14.

${ }^{69}$ While post-Fordism co-occurs with neoliberalism in much of the industrialized Global North, it is not necessary that the two occur together. The crisis of the Keynesian state provided the opportunity for capital to advance the neoliberal agenda and tear down perceived barriers to profitable accumulation, include trade unions but Jessop argues that the abstract characteristics of a post-Fordist state involve supply-side economics, the subordination of social policy to the demands of labour market flexibility, and structural competitiveness. There are different ways that these can be combined, suggesting that there are solutions to the crisis of the Keynesian welfare state and Fordism that are capitalist but are not reducible to neoliberalism.
} 
'accelerated pace of internationalization. ${ }^{70}$ The pace of internationalization, a form of economic globalization, gave rise to competitive pressure on manufacturing plants in the North from newly industrialized countries. Free trade agreements, a facet of economic globalization, have shaped industrial policy in Canada. As McBride argued, NAFTA has inhibited 'an industrial policy in Canada other than free trade by prohibiting a wide range of performance requirements that might be imposed on foreign or even domestic investors... The architecture of these international agreements reflects the neoliberal goals of constraining the state and freeing investors and markets from state intervention. ${ }^{71}$

Such free trade agreements, notably via their impact on manufacturing, are one of the important ways the CAW has experienced globalization. Increased pressure on wages and employment conditions in an increasingly internationalized economy has allowed automotive capital to move production away from Canada to newly industrializing countries, leading to job losses and pressure on wages. As detailed in chapter three, 1988 saw the signing of a free trade agreement between Canada and the United States, which was later expanded to include Mexico in 1994. The opening up of the North American economy marked a major point of neoliberal policy development in Canada. The wake of both of these free trade agreements saw a decline in the Canadian manufacturing footprint, as the pace in which manufacturing jobs left Canada dramatically increased. Neoliberal globalization, then, represented a direct threat to the CAW: the union's membership base began to erode, which in turn eroded the financial base of the union; all this was linked in with a broader political environment which was hostile to trade unionism. Under the auspices of staying globally competitive, manufacturing capital has

\footnotetext{
${ }^{70}$ Jessop, "Towards a Schumpeterian Workfare State?," 11.

${ }^{71}$ Stephen McBride, Paradigm Shift: Globalization and the Canadian State, $2^{\text {nd }}$ Edition, (Halifax:
} 
increasingly demanded concessions from unions. These concessionary demands have taken the form of 'huge wage concessions, two-tier wage systems, and the dismantling of employer pension plans. ${ }^{72}$

Labour markets have been restructured in Canada during the neoliberal era, and these new neoliberal labour markets have seen 'significant groups of the population excluded from employment opportunities, and considerable polarization exists - not just in incomes, but in security of employment and vulnerability to the employment cycle - among those who do manage to find employment. ${ }^{73}$

Neoliberalism involves a broader political assault on trade union freedoms and other forms of collective economic action. As unions are seen as a barrier to profitable capitalist accumulation part of the neoliberal program has been to undermine the power of trade unions. One of the most prominent and sustained attacks on trade unions during the neoliberal era has come from the promotion of 'labour market flexibility.' Labour market flexibility has often translated into assaults on trade union freedoms, as trade unions, which negotiate clear rules for the length of the workday, the hours worked, and the level of wages, are seen as a structural barrier to flexibility.

Kim Moody notes that flexibility involves 'the functional (deployment), numerical (staffing level), and time (scheduling) flexibility of the workplace that provides much of the cost reduction in the core of production. ${ }^{, 74}$ Functional flexibility is achieved by the reduction or elimination of job descriptions or demarcation while time flexibility is found in new forms of

\footnotetext{
Fernwood Publishing, 2005), 167.

72 Andrew Jackson, "Up Against The Wall: The political economy of the new attack on the Canadian labour movement," Just Labour: A Canadian Journal of Work and Society 20 (Summer 2013): 59.

${ }^{73}$ McBride, Paradigm Shift, 111.

${ }^{74}$ Kim Moody, Workers in a Lean World: Unions in the International Economy, (London: Verso, 1997),
} 
shift scheduling and in the massive use of overtime, sometimes without overtime pay. ${ }^{75}$ In its simplest, 'flexible labour' means low-cost and highly controllable. Casual and disposable labour allow for greater levels of capitalist accumulation, as capital is not tied to providing for a fixed labour force. Labour can be discarded to increase profits, and capital can outsource labour to low-cost jurisdictions as another way to increase profits. By introducing labour market flexibility, plants in the Global North hope to be able to compete with the much lower waged production in the Global South. The casual and flexible form of the labour market has produced, as Linda Briskin argues, a climate where equity measures and equality bargaining are under threat. $^{76}$ The policies of neoliberalism 'are reshaping the household-workplace-community nexus. Ideologically and structurally, they are re-invoking outdated and conservative views of women's place, reconfiguring the positioning of women's rights, and, to some extent, engineering women's return to the household.' ${ }^{77}$ Warskett concurs: 'the current state of the economy and politics is increasing the difficulty of achieving equal pay and other gains for women. ... The loss of manufacturing jobs and the increasing numbers of bad jobs in the service sector make the option of employment equity through affirmative action measures less and less of a possibility.' 78 While capital has sought to introduce greater flexibility in the labour process, neoliberal governments have moved to introduce greater flexibility in the labour market via direct assaults on unions and union rights.

The policies and ideology of neoliberalism have thus involved attacks on trade union

95.

${ }^{75}$ Ibid

${ }^{76}$ Linda Briskin, “Austerity, union policy and gender equality bargaining,” Transfer 20 no 1. (2014): 116117.

${ }^{77}$ Ibid.

${ }^{78}$ Rosemary Warskett, "The Politics of Difference and Inclusiveness within the Canadian Labour Movement," Economic and Industrial Democracy 17 (1996): 618. 
freedoms. Panitch and Swartz suggest that neoliberalism is characterized by 'the unprecedented severity of ad hoc coercive measures by the state, and the construction of a new ideology that generalized the state's new coercive role to the working class as a whole. ${ }^{79}$ These ad hoc measures seek 'to contain or repress manifestations of class conflict as practiced within the institutionalized freedom of association. Actions that were legal under general legislation increasingly were declared unlawful for particular groups of workers, or for all workers, for a particular period of time. ${ }^{80}$ As Andrew Jackson notes, the neoliberal era has seen an increase in employer power through "changes to labour law that have made new organizing more difficult, and intensified state intervention in free collective bargaining. ${ }^{81}$ An increasingly globalized economy and domestic 'flexible' labour markets put a great deal of pressure on trade unions wage settlements are challenged, plants themselves may be closed, and, perhaps most fundamentally, unions are no longer seen as legitimate policy actors. Building on an environment of high unemployment, the growing mobility of capital and the cut-throat competition for vehicle markets between automobile manufacturers, the economic environment of neoliberalism has fostered a culture of competitiveness that is internalized by workers and managers alike and becomes a basis for evaluating their own decisions and actions. ${ }^{82}$

The neoliberal era has seen private sector union density diminish, and with this, bargaining power has diminished as well. As Jackson points out, "the labour movement has found it increasingly difficult to connect in a positive way with workers. The right has found it

${ }^{79}$ Leo Panitch \& Donald Swartz, From Consent to Coercion: The Assault on Trade Union Freedoms, $3^{\text {rd }}$ Edition, (Aurora: Garamond Press, 2003), 30.

${ }^{80}$ Ibid, 28.

${ }^{81}$ Jackson, "Up Against The Wall," 52.

${ }^{82}$ Charlotte A. B. Yates, "Defining the Fault Lines: New Divisions in the Working Class," Capital \& Class 66 (Autumn 1998): 125. 
easier to frame unionized workers as a working-class elite." 83 This frustrates the role of unions in class formation: unions are forced into a defensive position, needing to reframe themselves to the very workers they are designed to defend not as "elites," but as political actors to defend the broad interests of the working class.

A very real legislative assault has taken place on trade unions: 'weakening, bypassing, or violently destroying the powers of organized labour is a necessary precondition for neoliberalization. ${ }^{, 84}$ Increasingly, the political right in Canada has been more willing to entertain the adoption of American-style anti-labour laws, on behalf of political pressure from Canadian capital. $^{85}$ For instance, the conservative party in Saskatchewan campaigned on a platform that included abolishing the Rand formula; for now, has backed away from that plan in favour of other, more incremental attacks on unions. The conservatives in Ontario proposed abolishing dues check-off, and federally the Conservative government has challenged union financing laws, and introduced private members bills to attack the Rand formula in the federal jurisdiction. ${ }^{86}$ The state has also often intervened in free collective bargaining: while this occurs more frequently in the public sector, the Canadian state has also influenced CAW bargaining.

Neoliberalism has thus posed a number of complex and interrelated challenges to the CAW. Economic globalization, supported by the Canadian state, has led to a series of plant closures which have weakened the union's economic and political power. These plant closures in turn prompted the union to move beyond its traditional base in the face of declining membership, which has, in turn, led to challenges of representing all of the its members. In

\footnotetext{
83 Jackson, "Up Against The Wall," 60.

${ }^{84}$ Harvey, A Brief History of Neoliberalism, 116.

85 Ibid, 56.

${ }^{86}$ Ken Lewenza, “A New Union for Challenging Times: A Reply to Andrew Jackson,” Just Labour: A Canadian Journal of Work and Society 20 (Summer 2013): 70.
} 
terms of electoral politics, the NDP has embraced neoliberalism, distancing itself from its labour identity, and has proved ineffective in presenting an alternative view to neoliberal orthodoxy or even to free trade.

\section{Methodology}

This dissertation employs a qualitative case study approach. Berg and Lune outline the major strength to qualitative case studies is that 'by concentrating on a single ... institution, the researcher aims to uncover the manifest interactions of significant factors characteristic of this ... institution. In addition, the research is able to capture various nuances, patterns, and more latent elements that other research approaches might overlook. ${ }^{87}$ One of the goals of the dissertation is to illuminate how the internal dynamics of trade unions shape the way they navigate challenges they encounter. In particular, this dissertation looks at how the CAW has responded to the challenges posed by neoliberal globalization. As such, the deep qualitative case study allowed for an in-depth analysis of numerous variables across multiple decades, which yielded a great deal of data to help answer the questions asked. As a large private sector union, there was a great deal of data that could be generated, which strengthened the case study.

As this dissertation studies the internal dynamics of trade unions, how they relate to class formation and, more specifically how these shape the union's strategic choices, the CAW Council was chosen as the primary grounds for collecting data and analyzing the union. The CAW Council, which constituted as a key place where the national leadership and rank-and-file activists regularly meet and played a critical role in the operations of the union. Its role is crucial to understanding the way the union functioned as an agent of class formation. The CAW

\footnotetext{
${ }^{87}$ Bruce L. Berg \& Howard Lune, Qualitative Research Methods for the Social Sciences, $8^{\text {th }}$ Edition, (Toronto: Pearson, 2012), 327.
} 
Council acted as a 'buckle' of mid-tier activists, connecting the leadership to the rank-and-file. This makes it of particular interest to questions about class formation: it is an excellent source of data to see how relationships between the rank-and-file and the leadership play out, how questions of class are formulated, mediated, and reformulated, and how strategies of fighting back against neoliberal globalization are structured and implemented.

The Council was chosen as a key research site as it involved participation from both rank-and-file members and the union leadership. It was comprised of rank-and-file members of the union, elected to represent their local, and met on a regular basis. ${ }^{88}$ The Council constituted the "parliament" of the union, where rank-and-file members debated union policy, and the union leadership was required to report to members on all of its activities. The council thus played an important role within the union by connecting rank-and-file activists to the national leadership and national staff on a regular basis. As a consequence, the CAW Council provided for a forum for important debates over strategic choice to occur within the union. While the leadership rarely lost votes, Council debates at times have pushed the leadership in new directions or forced the leadership to modify proposed policies that failed to resonate with the membership. At the same time, the CAW Council has provided a way for the national leadership to exert control over the direction of the union - particularly within elected positions - and to set the parameters of debate within the union.

The data collection for my dissertation occurred in two distinct phases. The first phase involved an extensive use of archival research to process-trace the political history of the CAW from 1985 to 2010, looking in particular at the organizing, bargaining, equity politics, and

\footnotetext{
${ }^{88}$ When the CAW was the Canadian UAW, the Council met six times a year. Upon the founding of the CAW, Council met three times a year. Shortly after Buzz Hargrove became national president, Council began
} 
electoral politics of the union. These archives were accessed at the CAW national headquarters in Toronto, Ontario. The main source of archival data was the minutes of the meetings of the CAW Council. The CAW kept a verbatim transcription of all Council meetings at their national headquarters. In this way, the archival research provided an unfiltered read of the debates within the union - the words were read as they were spoken to the council. The first phase of data collection involved going through the CAW's extensive archives, looking at convention and conference materials officially published by the CAW, but more importantly, going through the transcripts of the CAW Council. These archived transcriptions of discussion allowed for an 'unfiltered' view of what both rank-and-file activists and union leaders said and for which they advocated.

Catherine Welch argues that one of the great strengths of archival research is 'generating developmental explanations, in other words, explaining processes of change and evolution. ${ }^{89}$. While the Council's purpose, and its relationship to the union leadership, have changed over time, it remains an excellent window into how decisions within the union were made and carried out. ${ }^{90}$ The use of the transcripts from the council floor allowed me to trace the development of issues and politics over time, and see how the rank-and-file was able to shape the politics of the union, and how the positions of the union's leadership changed - or did not change

meeting twice a year.

${ }^{89}$ Catherine Welch, 'The archaeology of business networks: the use of archival records in case study research,' Journal of Strategic Marketing 8 (2000): 198.

${ }^{90}$ It is worth noting that other Canadian unions have conferences and conventions that meet regularly. The CAW Council differs in some meaningful ways. First, it meets more regularly than many other union conventions, some of which may meet only once every one to three years. Second, much more emphasis is placed, within the CAW, on a President's report, and a debate that surrounds it. Lastly, the intended purpose of the Council is to hold the leadership accountable to the rank-and-file. While the extent to which the body does this is debated within this chapter, the fact that this remains the purpose of the body is one of the ways in which Council can be differentiated from other union deliberative institutions. 
- over time.

The transcriptions identified all speakers by name and local. In this dissertation, however, a conscious decision was made not to cite these individuals by name when citing an intervention. While delegates to CAW Council knew that a transcription was taking place, these transcriptions were generally only available to CAW locals, making it ethically inappropriate to name individuals. The relative anonymity that delegates to council experience increases the reliability that the data collected is an accurate representation of the views of CAW members and the CAW as a whole. When citing interventions at Council in this dissertation, the speaker was identified as 'a brother' or 'a sister' or simply 'a speaker.' Exceptions to this were made, and particular individuals were cited by name, if these individuals were later interviewed for this project or if the individuals were 'elites' within the CAW and could reasonably expect to have their views and words be repeated publically.

The president of the union made regular reports to the council, including reports on his activities and the activities of the union's national staff. These reports included recommendations, which were debated and voted upon on the council floor. The reports generally included updates on matters within the union (bargaining, organizing, electoral politics, etc), as well as updates from around the Canadian labour movement, the international labour movement, and frequently, discussion about progressive politics worldwide. Sam Gindin - the former head of the union's research department, and former assistant to the national President, went on to write a book on the CAW - notes that where the president placed information in his report was almost as important as what was included in the report. For example, if the president discussed factory closings in the first few pages of the report, he intended to highlight this issue; if the factory closings were much later in the report, they were considered of lesser importance at 
this juncture. ${ }^{91}$ The staff, including the heads of departments in the union, also made reports to council that were debated, and this allowed for regular updates on the projects the union was undertaking, as well as the progress of organizing and collective bargaining.

The archives thus represent a rich and deep body of information, but they are subject to interpretation. Context matters. The archives do not allow one to see the debates and discussions that took place away from the microphones, nor do they allow one to see the way the Administrative caucus has influenced the direction of the CAW. As was pointed out during an interview, the minutes of the council do not capture things like LGBTQ activists handing out information to delegates coming into the Council. ${ }^{92}$ Archival work also presents the challenge of missing data. Although the collection at the CAW headquarters was quite complete, several president's reports or council minutes were missing from the collection. The missing reports and minutes did not present an insurmountable challenge, however as most of the issues debated at council were ongoing, and that the reports of the staff and president were comprehensive, in most cases it was easy to extrapolate what was missing from the data.

Confirming data from archival research can also be done through triangulation - bringing more than one source of data to bear on a single point. Welch shows that using different research strategies, in particular interview data alongside archival data, is a powerful form of triangulation as the researcher can achieve the best of each research strategy while overcoming their unique challenges. ${ }^{93}$ The use of semi-structured interviews as another data collection tool allowed me to fill in the few holes of missing data - by asking those that were at Council, the

\footnotetext{
${ }^{91}$ Sam Gindin, in discussion with the author, August 2011.

${ }^{92}$ Sue Carter, in discussion with the author, September 2013.

${ }^{93}$ Welch, "The archeology of business networks," 199.
} 
assumptions made about missing data, or the themes of the discussion, could be confirmed or rejected.

The second phase of the research thus involved sixteen semi-structured in-depth interviews with key elites presently or formerly with the CAW. Initial interviewees were selected through a number of criteria. First, I sought out those that made routine interventions at Council - both those who challenged the leadership and those who agreed with the leadership. Second, a group of elites within the CAW who had positions which related to my main areas of investigation - electoral politics, equity, organizing, and bargaining - were chosen. This led me to interview present, and some former, staff heads of departments within the CAW, including the equity department, the women's department, organizing, and political action. Elites within the CAW were also chosen if their roles involved significant overlap in these areas of interest. To this end, present and former presidents of the $\mathrm{CAW}^{94}$, members of the research department, and the union's economist were interviewed. Lastly, I employed a snowball sampling method: many of my initial interviewees suggested other potential interviewees, many of whom I had not come across in my archival work, for interviewing. The purpose of these interviews was to triangulate findings from my archival research. In most cases, the interviews also allowed me to get information that simply could not be found in the archives. For example, much of the discussion about the role that Council plays in the union came from interviews.

In virtually all cases, the interview started with a 'grand tour' question which asked interviewees to discuss the day-to-day activities of their department, or their impressions of the union as a whole. Leech suggests that such questions are among the most effective in semi-

\footnotetext{
${ }^{94}$ Buzz Hargrove and Ken Lewenza were interviewed. It was my intention to seek an interview with Bob White, however, White was too ill to be interviewed.
} 
structured interviews as they 'get respondents talking, but in a fairly focused way.' ${ }^{95}$ These questions helped put the interviewees at ease, provided a great deal of information, and helped to shape the direction of subsequent questions. All the interviews were closed by asking the respondent if they wished to add anything, or "to answer a question I had not asked." The information from the interviews was incredibly rich. In many cases, it confirmed hunches gleaned from the archival work. The interviews proved invaluable when it came to uncovering information that would not come up in the minutes of the Council.

Accordingly, the semi-structured interviews with key figures supplied a crucial source of supplementary information not available through the archives. The interviews also served to test my interpretation of the archival material. Many interviewees provided confirmation unprompted - of what other respondents had said. Some of the interviews were more fruitful than others; many of the interviewees who had left the CAW for various reasons were more forthcoming than those still in the union. Those still within the union may be seeking to defend their organization, or their position within the organization, and may be more guarded with what they say. However, the in many cases those who had exited from the CAW confirmed statements of those still within the union, suggesting that the overall data was quite reliable.

Thus the major value of the archival data was the rich picture of the CAW Council that it presented. However, the council minutes did not cover the complete picture of the CAW Council. The elite interviews helped fill in these gaps. The interviews were also rich with data, and provided a great deal of context for what happened within the union outside of council, and 'behind the scenes' at Council.

\footnotetext{
${ }^{95}$ Beth L. Leech, “Asking Questions: Techniques for Semistructured Interviews” PS Political Science 35iss 4 (December 2002): 667.
} 
The archival material and the interviews made it clear that CAW Council indeed has served as a forum for debate where a range of ideologies - left and right leaning social democracy, socialism, Canadian nationalism - are expressed. The debates sometimes lead to new policies, or see policies of the leadership endorsed. In its later years, however, the Council, served increasingly as a rubber stamp of the ideological position of the leadership - a centrist social democracy. Yet while the Council - and especially the Administrative Caucus - provided a means for the leadership to exert control over the membership, the leadership cannot be described as autocratic, as it has showed genuine interest in debate. From time to time, the leadership would also reduce its own power as when, in 1994, President Hargrove thought it was undemocratic for him to end a strike with the approval of the NEB. Hargrove instead asked for a constitutional amendment to allow the ending of a strike only if a majority vote of the NEB and delegates to the CAW Council agreed. ${ }^{96}$

\section{Conclusions}

This chapter has outlaid the theoretical framework that guides the dissertation. A question of particular importance is how unions contribute to class formation. Unions can play a critical role in shaping the politics of a class for itself, as they can aggregate the interests of a class, and shape those interests into cohesive form. Of particular importance to the study of the CAW, the question of how 'mid-tier' activists - those that connect the rank-and-file to the union leadership - act within a union. The CAW Council provided an excellent forum for mid-tier activists to shape union policy. This dissertation also looks at the problem of diverse interests within a union, and how unions accommodate interests from different groups - sectoral and non-

\footnotetext{
${ }^{96}$ April 1994 Council, President’s Report, 26.
} 
sectoral - as the union grows more heterogeneous.

Unions have the potential to develop class consciousness among members of the working class. By creating cultures of solidarity, by highlighting commonalities between workers, and by aggregating, articulating, and bargaining for issues of benefit to their members, there is potential for unions to build working class consciousness and working class politics. However, as unions are not the primary organizers of workers - employers of workers are - and workers' identities are informed by many factors outside of their position in the labour market, the potential of class consciousness is bounded by environmental factors external to unions and the presence of multiple identities. In particular, unions may find themselves in a collective action dilemma when they organize outside of their traditional base and become more sectorally heterogeneous, a necessity for many unions in the neoliberal era. As unions organize new groups of workers and become more heterogeneous, unions must strive to provide meaningful incorporation of these new workers into the structures of the union, the workplace, and civil society. This can make class formation difficult but it also offers the possibility of enriching working class identities and subsequent moments of class reformation.

Unions may look to multiple paths to fight against the challenges they face; this can include strategies both within and external to traditional political institutions. Social democratic parties are one political institution through which unions may pursue working class politics. Social democratic and socialist political parties have the theoretical potential to act as vehicles for working class politics by offering a clear electoral alternative to bourgeois political parties. However, many social democratic and socialist parties, in the post-war era built an identity around being strong supporters of the Keynesian Welfare State. With the collapse of Keynesianism, these parties no longer had a clear ideological identity, and this shook the ties 
with organized labour, and, by extension, weakened the potential for social democratic parties to offer a working class politics by failing to offer an alternative to neoliberalism. Working class politics are mediated by the relative strength of the labour movement and of the strength and position of working class political parties but the strategies unions choose to employ at a particular time depend on the material circumstances, including the relative strength of capital and the role of the state.

The CAW has only existed in a climate of neoliberalism, and, as such, understanding neoliberal ideology and practise in the Canadian context is important. Neoliberalism is hostile towards all forms of collective action, especially trade unions. In the Canadian context, neoliberalism is closely linked with the policies of free trade, pursued by both Conservative and Liberal federal governments. Linked with questions of neoliberalism are questions of how working class political parties - ostensibly the NDP in Canada - have fared under neoliberalism. Many social democratic and labour parties, including the NDP, closely linked their identity to supporting a strong welfare state during the Keynesian era. As Keynesianism collapsed and gave way to neoliberalism, many social democratic parties became 'hollowed out' and did not have a coherent identity. The NDP, like many social democratic parties has shifted its policies rightward, and has not been able to present a clear alternative to neoliberalism. This shift, in turn, helps to account for the CAW's embrace of strategic voting.

As subsequent chapters will discuss, the Council played a key role in the CAW as an agent of class formation. The Council acted as a site where mid-tier activists would link the leadership to the rank-and-file. It was here that the union worked out its strategic responses to neoliberalism, globalization, deindustrialization, and other challenges it faced. The Council also acted as an important forum for equity seeking groups to change the union and their workplaces. 


\section{Chapter Two: History}

\section{Introduction}

The major purpose of this chapter is to provide a historical overview of the emergence of the Canadian Autoworkers from the United Autoworkers. Against the backdrop of the changing nature of the North American auto economy, it examines the union's changing stance towards electoral politics and the way the union acted as a pace-setter within the union movement with respect to equity. The aim is not to provide a comprehensive account, but rather a summary of key events and factors that have had an impact on the development of a class-based identity in the Canadian UAW.

The rich history of the UAW, and the Canadian UAW that emerged from it, is often one of its trend setting role vis-a-vis the North American labour movement, and it is, at times, a story of 'fighting back' - resisting concessions, and developing a class-based politics that challenges capital, and, at times, the state.. As White noted,

'The UAW has a tradition of setting the pace for collective bargaining for the labour movement. In 1949 it obtained the first company-paid pensions. .. In 1955 the UAW tried to get the world's first guaranteed annual wage ... The UAW got North America's first prescription drug plan, the first survivor-pension benefit paid by the company, the first major cost-of-living allowance provision, the first comprehensive health care program covering the worker's entire family and funded by the company.' ${ }^{1}$

He went on to point out however that the success of the UAW as a leader in the labour movement was largely tied to the economic strength of the union rooted in a strong North American auto manufacturing. ${ }^{2}$ Indeed, the strength of the UAW and later the CAW was, and remained through the entire history of the union, very closely tied to the positon of The Big

\footnotetext{
${ }^{1}$ Bob White, Hard Bargains. My Life on the Line (Toronto: McClelland and Stewart, 1987), 41.
} 
Three auto manufacturers. As a result, the UAW and in the CAW have also worked to ensure the profitability of The Big Three in order to enable the union to pursue a strong collective bargaining agenda and, more broadly, to push for social progress.

The chapter provides a brief overview of the political foundations of the UAW and then focuses on the Canadian Autoworkers under Keynesianism. The next section, on the emergence of the Quebec wing of the UAW during the late 1960s and 1970s, establishes its existence as an entity separate from the Canadian UAW. The last two sections look at the crisis of the Keynesian Welfare State in the 1960s and 1970s and the emergence of neoliberal globalization and a 'flexible' labour market. Each section discusses the external political and legalinstitutional environment, the way the internal structures of the union, particularly the Council, contributed to the union, the internal factional struggles, and the relationship to party politics. The chapter concludes by providing an overview of the CAW Council in the context of the larger union, which establishes the framework for the substantive chapters to follow.

\section{The Foundation of the UAW and Early Political Configurations}

Founded in 1936 in South Bend, Indiana, the UAW emerged out of a broader industrial unionism movement that rejected the AFL's craft unionism. ${ }^{3}$ The importance of the break from craft unionism should not be understated. The movement reflected/benefited from a clear shift to the left within the North American labour movement, and certainly helped create a culture of inclusivity and a broad working class politics within the UAW. The UAW's formative years were marked by a turn from cooperation to competition. Cooperation between communists and social democrats in the North American labour movement reached its peak in the years leading

\footnotetext{
${ }^{2}$ Ibid.

${ }^{3}$ Charlotte A. B. Yates, From Plant to Politics: The Autoworkers Union in Postwar Canada (Philadelphia:
} 
up to the formation of the UAW but then deteriorated into sharp struggles for hegemony of the left. ${ }^{4}$ The conflicting demands of the social democratic CCF and the Communist Party were reflected in internal union conflicts over positions and policies ${ }^{5}$ The early internal politics of the UAW and Canadian UAW were thus dominated by the struggle between the left-leaning and right-leaning factions to control the union. ${ }^{6}$

Virtually all activists within the Canadian UAW were situated to the left-of-centre, thus the terms 'right-leaning' and 'left-leaning' are used to broadly define the factions within the union, and their relation to the political centre. The right-leaning faction was closer to the political centre (a centre-left outlook on the broader political spectrum), while the left faction was to the left of centre. The right-leaning faction of the UAW was almost exclusively socialdemocratic in outlook (although it included some Liberal party supporters). The left of the Canadian UAW was not a homogeneous force but it did coalesce around The Unity Caucus - a group based on the cooperation of communists, left-wing CCFers, Canadian nationalists, and militant trade unionists, ${ }^{7}$ This loose formation on the left persisted into the formation of the CAW. The most fundamental strategic challenge - to the Unity Caucus and to the Canadian UAW - came from the nationalists, who argued that union troubles could be avoided had Canadian autoworkers had autonomous control of their union. ${ }^{8}$ From the very formation of the UAW, then, questions over electoral strategy, and whether to work with social democratic

Temple University Press, 1993), 24.

${ }^{4}$ Sam Gindin, The Canadian Auto Workers: The Birth and Transformation of a Union (Toronto: James Lorimer \& Company, 1995), 38.

${ }^{5}$ Ibid.

${ }^{6}$ Sorting out the factionalism in the Canadian UAW can lead to headaches. For the sake of brevity, the factions are referred to as "right leaning," meaning the social democrats and those to the right of them, and "left leaning" as those in the Unity Caucus - communists, socialists, anarchists, and left-leaning social democrats. This distinction is certainly crude, but it is how these divisions played out on the Council floor.

${ }^{7}$ Gindin, The Canadian Autoworkers, 29. 
parties, dominated political debate within the union.

The first Canadian UAW local, Local 195 in Windsor, was established in December 1936. While the Canadian UAW was thus part of the UAW from the union's earliest days, it was long a 'junior partner' in the international union. As Yates notes 'the UAW had little interest in and even fewer resources to contribute to the organization of Canadian workers. Secondly, Canadian workers had no Wagner Act with provisions for legal recognition of unions and compulsory collective bargaining.' 9 In other words, the lack of an institutional framework meant that the Canadian UAW had to continually struggle, often without the support of the American parent union, to establish and maintain its position in the workplace. ${ }^{10}$ The post-war political-economic arrangements of the Keynesian Welfare State and institutionalized collective bargaining through PC 1003 helped normalize relations between the union and capital, while at the same time, it curbed some militancy present within the union.

Keynesianism and the 'Golden Age' of Capitalism

The Keynesian era was generally a period of relative strength for the Canadian UAW and the broader UAW. While the specific institutional arrangements of the post-war compromise, outlined below, did constrain some of the radicalism within its ranks, the union generally benefitted from the demand policies of Keynesianism which saw high levels of consumption, particularly of vehicles. This contributed to the strength of domestic auto manufacturers, which, in turn, put the union in a strong bargaining position. The union did face some questions of inclusion, particularly from women workers and workers of colour, but, by and large, the union

\footnotetext{
${ }^{8}$ Ibid, 30.

9 Yates, From Plant to Politics, 24.

${ }^{10}$ Ibid.
} 
was comprised of white men. This meant that the UAW did not face the representation challenges detailed by Offe and Wisenthal. During this time the Council was also coming into its own as an organization, and featured frequent debates between the rank-and-file and the leadership, as well as the factions within the union.

The Canadian wing of the union began drifting away from the American UAW during the 1940s. The Canadian Region overwhelmingly rejected the no-strike pledge and other sacrifices agreed to by US autoworkers. ${ }^{11}$ This marked a significant departure from the American UAW towards a much more militant stance in bargaining and general strategy. Yates notes that there was a distinct separation of strategy, with the Canadian UAW drifting apart from the American UAW, emerging from WWII as a 'militant syndicalist orientation and a strong tradition of rankand-file activism and democracy. These characteristics constituted the core of the union's collective identity and remained dominant until the late 1950s. ${ }^{12}$

The changing nature of the legal-institutional context of labour relations however placed some constraints to the way the Canadian UAW operated. The effects of the adoption of the Wagner Model in the United States were felt within the Canadian UAW. The Wagner Model effectively limited class politics within unions by limiting conflicts "between "us and them" to the distribution of productivity gains. Labour-management adversarialism was not eliminated, but the UAW helped to focus worker discontent on a narrower economism. ${ }^{13}$ The Canadian counterpart to the Wagner Model, PC 1003, was the norm for industrial relations here. PC 1003, an order-in-council passed by the Canadian government in 1944, established the new legislative

\footnotetext{
11 Ibid, 35.

${ }^{12}$ Charlotte A.B. Yates, “The Internal Dynamics of Union Power: Explaining Canadian Autoworkers' Militancy in the1980s" Studies in Political Economy 31 (Spring 1990): 79.

${ }^{13}$ Ibid, 172.
} 
environment for industrial relations.

PC 1003 was defined by three distinctive elements: compelling employers to bargain with unions, compelling conciliation, and compelling grievance arbitration. ${ }^{14}$ Unfair labour practises were defined, union's lawful activities were protected, and it was now illegal for an employee to be threatened or discriminated against for exercising union rights. PC 1003 included acceptance of trade union rights and collective bargaining, but often this acceptance was bounded. For example, certification votes and compulsory collective bargaining for trade unions were recognized, but in exchange recognition strikes were outlawed. Fudge \& Tucker note that it was the restrictions on when strikes could legally occur, the rendering of strikes 'unlawful over jurisdictional issues, recognition issues, and application or interpretation issues. Only in the negotiations area were they left, and even then they were to be held in suspension during compulsory conciliation' which made PC 1003 outstanding. ${ }^{15}$ The Wagner / PC 1003 model of industrial relations thus legitimated unions and provided for union stability and security, but also set strict legal limits on when collective bargaining and striking could take place, and what could be covered by collective bargaining agreements.

Importantly, Fudge \& Tucker argue that 'the legal recognition of trade unions tended to flow from their capacities and liabilities, rather than from a positive acknowledgement of their legitimacy.' 16 The fact that unions were made formally legal due to their capacities and liabilities, rather than through their inherent legitimacy, had wide-ranging impacts on how unions could operate internally, on strikes, organizing drives, and on the procedures and jurisdictions of

\footnotetext{
${ }^{14}$ Judy Fudge \& Eric Tucker, Labour Before The Law: The Regulation of Workers' Collective Action in Canada, 1900 - 1948, (Don Mills: Oxford University Press, 2001), 273.

15 Ibid.

${ }^{16}$ Ibid, 275.
} 
collective bargaining. The changes to the collective bargaining regime that occurred under PC 1003 had a strong impact on the Canadian UAW. The order provided for compulsory conciliation before strikes, and banned strikes during collective agreements. Compulsory conciliation greatly benefited capital, allowing management to prepare for strikes by hiring scabs and stockpiling goods. Another major detriment to the Canadian UAW coming out of PC 1003 was the decentralization of bargaining. Unions had to be established at the plant level - meaning organizing had to be done plant-by-plant, which inhibited the establishment of sector wide bargaining. While many European trade unions had legislatively established sector wide bargaining, it was only through the considerable industrial strength wielded by the union that the UAW was ultimately able to establish pattern bargaining.

The decentralization of bargaining resulting from PC 1003 has had a profound effect on the type of worker organized into trade unions. The post-war collective bargaining regime is centred around a single employer in a single location, and this has led to the

'fragmentation of the labour movement into separate bargaining units with exclusive bargaining agents [which has] had, and continues to have, profound implications both in terms of class power and other kinds of inequality based on gender, race, and ethnic differences. ... Isolated bargaining units reinforce fragmented class power, and the development of a collective bargaining system and union movement centred almost exclusively on the local workplace and workplace issues. ${ }^{17}$

In addition, the post-war industrial relations regime has led to a 'profound gender bias in the determination of the bargaining unit.... Women do different work from men and exercise different skills in performing their job tasks. Occupational segregation of women and men in the workforce is therefore reinforced in the determination of

\footnotetext{
${ }^{17}$ Rosemary Warskett, "The Politics of Difference and Inclusiveness within the Canadian Labour Movement," Economic and Industrial Democracy 17 (1996): 596.
} 
bargaining units and structures.' 18

The second major development in the Canadian post-war industrial relations regime was a direct result of Canadian UAW workers. In 1945 Ford workers struck, partially over union security and union dues. The Judge overseeing the settlement, Justice Ivan Rand, provided a compromise which, to this day, is a foundational principle of Canadian industrial relations. All workers covered by a collective agreement, regardless of their membership in the union, would be subject to automatic dues check-off. In return, however, unions had to behave responsibly by repudiating illegal strikes and disciplining members who participated in them. Unions won financial security through automatic dues check-off, but this security came at the cost of two conditions to unions. First, the union was required to conduct a secret ballot of all employees in the bargaining unit as a condition for engaging in lawful industrial action. Second, 'the union's right to have the employer remit its dues depended on its fulfilling its responsibilities. Not only was it obligated to repudiate strikes that occurred while a collective agreement was in effect, but it was obliged to discipline members who participated in wildcats. ${ }^{19}$

Thus the growth of the post-war industrial relations regime could not be considered an unqualified victory for labour. Elaborate certification procedures, legally enforceable contracts, no-strike provisions, and liability of unions for illegal strikes, all pushed unions towards a more bureaucratic structure, and a more "responsible unionism," where militant behaviour was discouraged, and the union's leadership played a role in "policing" the rank-and-file. The Rand Formula was criticised by the left as contributing to deradicalization as stewards no longer necessarily had weekly direct contact with their members. The Rand Formula also created the

\footnotetext{
18 Ibid 597.

${ }^{19}$ Fudge \& Tucker, Labour Before The Law, 285.
} 
conditions where workers could get the benefits of a collective agreement without participating in the union. On the whole, while PC 1003 and The Rand Formula provided security to the trade unions they legalized, they did so at the cost of distancing the membership from the leadership. Union leadership became more legalized, and began to rely more heavily on staff, rather than on members, to carry out the functions of unions. The post-war industrial relations regime was largely based around the male breadwinner. As Warskett notes, 'the collective bargaining system that developed during the war and the immediate postwar period brought greater workplace benefits to mainly male workers in the core manufacturing and resource sectors. ${ }^{20}$ While PC 1003 and The Rand Formula provided economic security for unions and their male members, it did little to advance the livelihoods of women workers. Indeed, as women have traditionally been found in "non-standard" forms of employment, the post-war industrial relations regime did little to make it easier to organize these women workers.

The post-war industrial relations regime in Canada shaped trade unions into more bureaucratic and legalistic entities. Fudge and Tucker outline that:

'Once PC 1003 was introduced, both the nature and the content of collective agreements changed. As grievance arbitration became a legally binding means of enforcing them, collective agreements grew longer and more formal. Lawyers advised employers of the need to obtain language that preserved their managerial prerogatives and banned strikes, and there was a marked increase in both management rights clauses and strike bans in collective agreements.' 21

Yates similarly argues that the post-war industrial relations regime, PC 1003 and the Wagner Act, led, in most unions, to 'a more hierarchical, bureaucratic and legalistic unionism that replaced the more militant, rank-and-file centred, and class-oriented unionism of the 1930s and

\footnotetext{
${ }^{20}$ Warskett, "The Politics of Difference and Inclusiveness": 594.

${ }^{21}$ Fudge \& Tucker, Labour Before The Law, 276.
} 
1940s. ${ }^{22}$ According to Wells, this shift took place in the UAW throughout the 1950 s, which resulted in a more hierarchical union with political action centred around national and international union leaders and staff. The locus of organizing workplace action within the UAW and Canadian UAW shifted from workers and local leaders to a less militant national leadership. $^{23}$

While militant syndicalism helped define the Canadian UAW, the 1940s nonetheless saw a relative decline in militant action, as compared to previous decades. Part of the explanation for this was the capturing of the Canadian UAW leadership by the right-leaning faction of the union. The 1946 and 1947 elections within the union saw Walter Reuther become President of the International UAW, which led to the dominance of the centre-right faction. The latter used Cold War tensions to marginalise local militants, branding them "communists." 24 The late 1940s was also marked by a chilling of radicalism within the Canadian UAW.

The Canadian economy slowed down in the 1950s which, foreshadowing many of the decades to come, adversely affected the auto industry. Waves of imports from Japan and Europe entered the Canadian market, and by the close of the decade, nearly a third of all cars sold in Canada were imports. This occurred alongside a slowdown in Canadian automotive exports, as foreign countries recovered after WWII. Imports and slowing exports dramatically had an adverse impact on the automotive industry, and the impact on the 'UAW was profound, between 1955 and 1960 the union lost nearly a fifth of its membership, or 6,000 workers. ${ }^{25}$

The Canadian UAW's response to these challenges reflected tensions between the

\footnotetext{
${ }^{22}$ Don Wells, "The Impact of the Postwar Compromise on Canadian Unionism: The Formation of an Auto Worker Local in the 1950s" Labour/Le Travail, 36 (Fall 1995): 150.

${ }^{23}$ Ibid, 151.

${ }^{24}$ Wells, "The Impact of the Postwar Compromise on Canadian Unionism," 154.

${ }^{25}$ Dimitry Anastakis, "Between Nationalism and Continentalism: State Auto Industry Policy and the
} 
political factions within the union. As Yates argues, the UAW leadership, led by Walter Reuther, sought

'continental integration of the auto industry and labour - management cooperation. ... The Left proposed an alternate for the future economic and union development that rested on greater national control of both the auto industry and the union. Central to the Left caucus' proposal was a strong state regulation of the auto industry and a strategy to begin building a Canadian-made car. ... The left Caucus rejected labour-management cooperation and instead demanded the right to strike over production standards. ${ }^{26}$

This struggle highlights what would become a telling feature of the Left within the Canadian UAW: a militantly left politics, led by the rank-and-file, intertwined with Canadian nationalism. For the Left Caucus, the goal was more rank and file activism, which it felt the International union stood in the way of. For the Left, Canadian economic independence from the United States and autonomy for the Canadian UAW would mean a stronger, more militant union. As Gindin notes, the Canadian left, when fighting with the American leadership, would appeal to both rank-and-file democracy, but also democracy linked to nationalism and Canadian autonomy. ${ }^{27}$ By the end of the 1950s, the International union had secured control over the Left Caucus in the Canadian Region. The nationalist opposition within the union was 'quashed,' as the international union successfully 'silenced the only viable alternative to industry-based private regulatory structures. The three year contracts reflected a growing moderation within the union. Gains were to be won through the slow process of compromise with management and an orderly collective bargaining relationship.'28

For the Canadian UAW, electoral politics grew complicated in the 1940s. The two

Canadian UAW, 1960-1970,” Labour/Le Travail 53 (Spring 2004): 97.

${ }^{26}$ Yates, From Plant To Politics, 95.

${ }^{27}$ Gindin, The Canadian Autoworkers, 128.

${ }^{28}$ Yates, From Plant to Politics, 99. 
factions, the left and the CCF dominated right, struggled to control the union's electoral strategy. As noted above, the Canadian UAW was a mix of communists, social democrats and union militants that wished to advance the union's status in the workplace. One faction, often to the right of the communists and union militants, sought to affiliate the UAW to the CCF. The entire electoral strategy was made increasingly complicated by a substantial number of Liberal Party supporters in the UAW. ${ }^{29}$ Yates notes that because of

'these complex internal dynamics, the Canadian UAW adopted a program of independent political action. It continued this course of action with little debate until 1943 when 34 CCF Members of Provincial Parliament were elected in the August 1943 Ontario provincial election, making the CCF the official opposition in Ontario. Nineteen of these MPPs were trade unionists, including two UAW members. ${ }^{30}$

After this election, at the Canadian UAW Political Action Convention, the union passed a resolution instructing all UAW locals to set up political action committees with the aim of educating the membership in the need for trade union political action. That said, even with the CCF victories, the UAW had openly rejected the political solution of mobilizing behind a political party and opted instead to reaffirm its commitment to a trade union centred strategy of independent action. ${ }^{31}$ This was reflective of the continual struggle between the right leaning wing and the more militant, union centred, left wing of the union.

Given the difficulty of navigating the complex party politics within the Canadian UAW, the Left Caucus' strategy during the 1940s was to move the union 'onto a course of work placebased action rather than party politics. The success of this strategy during and immediately following the war encouraged membership support for a trade-union centred strategic orientation

\footnotetext{
${ }^{29}$ Ibid, 42.

${ }^{30}$ Ibid, 43 .

${ }^{31}$ Ibid, 45.
} 
and reinforced the syndicalist tradition inside the union.' ${ }^{32}$ This strategy foreshadowed that adopted by the future CAW, which sought to combine electoral politics and militant workplace action.

Deep divisions over the union's position vis-à-vis the CCF became further entrenched in the 1950s. These divisions, however, were largely ignored by the union leadership. The 1957 Canadian election saw a leadership-led strategy of assisting the CCF to win elections. ${ }^{33}$ The 1957 election enabled the leadership to exert a great deal of control over the union's official political action, as all union staff were required to support the CCF and mobilize the locals they serviced to support the party. ${ }^{34}$ This marks one of the heights of the union working closely with the social democratic party of the day, the CCF, as the relationship between the two was exceptionally close at this time. The CCF did represent a working class party, and many of the policies the CCF espoused were closely linked with the goals of the Canadian UAW leadership.

Gindin argues, however, that the late 1950s also saw an expansion of the definition of politics within the Canadian UAW, moving beyond simple electoral activity. The union 'developed and maintained an emphasis on independent lobbying in a number of ways. It sent cavalcades to Queen's Park and Ottawa, organized the unemployed, and buttonholed MPs. ${ }^{35}$

During The 1940s the Canadian UAW remained ahead of much of the Canadian labour movement, but perhaps lagging behind society, in a number of key areas within the struggle for equity. According to Sugiman, "the UAW served as an ally, offering both a philosophical commitment to social (racial) equality and justice, and the material resources and tools with

\footnotetext{
${ }^{32}$ Yates, "The Internal Dynamics of Union Power," 79.

${ }^{33}$ Yates, From Plant to Politics, 131.

${ }^{34}$ Ibid, 132.

${ }^{35}$ Gindin, The Canadian Autoworkers, 136.
} 
which to seek it." 36 The UAW was committed, albeit unevenly, to advancing racial justice in the immediate post-war period. The UAW created fair employment practises in its locals, and 'although some were inactive, others helped in the campaigns for equal treatment. ${ }^{37}$ While on the one hand the union served as an ally, on the other, it worked to contain resistance, and union leaders often 'lacked an adequate understanding of racial and sexual discrimination, and they typically reduced both to class relations between workers and their employers. ${ }^{38}$ Articulating racial and gender struggles as class struggle would become important in the CAW, but the CAW understood the complex relations between class, race, and gender, and did not reduce all struggles to class.

With the onset of The Second World War, women autoworkers entered the workplace in greater numbers, which meant that the union had to navigate the issues of gender equality. As a union, the Canadian UAW was ahead of most Canadian unions when dealing with questions of gender at work. While the employers strictly enforced sex-segregation at the workplace, there was a great deal of popular support for women participating in wartime production. In 1942, locals warned the Canadian Council that 'unless the union is able to give leadership to the struggle for equal pay for equal work we will remain weak among the women., ${ }^{39}$ The Canadian UAW seemed to take this warning to heart, and, at times, used its considerable industrial strength to support the rights of women workers. For instance, in 1954 the Canadian UAW challenged company restrictions on the employment of married women. ${ }^{40}$

\footnotetext{
${ }^{36}$ Pamela Sugiman, "Privilege and Oppression: The Configuration of Race, Gender, and Class in Southern Ontario Auto Plants, 1939 to 1949” Labour / Le Travail 47 (Spring 2001).

${ }^{37}$ Julie White, "Looking Back: A Brief History of Everything," in Equity, Diversity, and Canadian Labour, ed. Gerald Hunt and David Rayside (Toronto: University of Toronto Press, 2007), 36.

38 Sugiman, "Privilege and Oppression."

${ }^{39}$ Gindin, The Canadian Autoworkers, 85.

40 Ibid.
} 
While the Canadian UAW supported the struggle for equal pay for equal work, largely to prevent employers from undercutting the wages of men by hiring workers, many women workers remained occupationally segregated into different - and lower paid - jobs than men. The workplaces were sex-segregated, with a specific gendered division of labour. Women autoworkers upheld conventional gender ideologies and sex-segregated work arrangements, however, they did so while covertly resisting gendered employment policies. For example, many women resisted company policies that prohibited the employment of married women. ${ }^{41}$

Job segregation would become an issue in later years, however, as the union tackled the issue of employment equity. As Julie White notes, 'At Ford a struggle ensued over equal pay, and the same problem arose as in earlier times: the employer refused to hire women at the same pay rates as the men but the UAW insisted, even to a strike of Local $200{ }^{, 42}$

Within the union, formal and informal organizing of women took place in the form of women's committees and caucuses. These committees 'had led several campaigns: for equal pay legislation, for maternity and parental leave, against sexism in the schools, for women's liberation reports and resolutions which go far beyond workforce equality to call for abortion rights and the socialization of housework. ${ }^{43}$ These committees became important institutions for women activists to meet and organize in, and played a key role in future equality developments within the union.

Racial and gender inequality were deeply intertwined in the 1950s. At this time, none of

\footnotetext{
${ }^{41}$ Pamela Sugiman, Labour's Dilemma: The Gender Politics of Autoworkers in Canada, 1937 - 1979 (Toronto: University of Toronto Press, 1994), 208.

${ }^{42}$ White, "Looking Back," 34. This flexing of industrial muscle backfired, however Once Ford realized they could not hire women at a lower rate of pay, they began outsourcing contracts to smaller and lower-paying feeder plants.

${ }^{43}$ Heather Jon Maroney, "Feminism at Work," in Feminism and Political Economy: Women's Work, Women's Struggles, eds. Heather Jon Maroney \& Meg Luxton, (Toronto: Methuen Publications. 1987), 89.
} 
The Big Three would offer employment to a black woman. ${ }^{44}$ Automakers would hire black men, but only to fill the most undesirable jobs in plants - jobs that almost no white man would take. ${ }^{45}$ UAW President Walter Reuther, in a move to advance both racial equality and push back against the Left in the union, linked racism to Nazism and Communist influence on American society. As a result of this push from the international leadership, the UAW was able to win formal equal rights for black men in collective negotiations.

The Emergence of the Quebec Wing of the UAW

The CAW does have a presence in Quebec. In the late 1960s and 1970s, however, the Quebec wing established a semi-autonomous relationship from the English speaking wing in the Rest of Canada. Although the dissertation focuses on the CAW in the Rest of Canada, it is important to include this event as a significant part of the historical background.

In 1965 a GM plant in St. Therese won UAW certification - the first auto plant in Quebec to be brought into the UAW. Through the late 1960s and into the 1970s, Quebec became a fertile ground for expanding UAW membership. The union committed increased resources to organizing in Quebec and by 197215 new plants, with a total membership of 1207, had been organized into the UAW. ${ }^{46}$ These workers were originally part of a homogenous UAW-Canada organization, represented at the Canadian Council of the UAW. However, during the late 1960s, the Quebec labour movement, and the FTQ specifically, was engaged in a struggle with Canadian unions for increased provincial/national autonomy. Thus as early as 1966, the FTQ pushed delegates to the CLC's national convention to give more autonomy to the Federation. As Savage notes, by the 1970s the 'FTQ won jurisdiction over union education and organizing in

\footnotetext{
${ }^{44}$ Ibid.

${ }^{45}$ Ibid.
} 
Quebec; jurisdiction over local and regional labour councils; and the transfer of both human and financial resources from the CLC to the FTQ. ${ }^{47}$ This struggle for more autonomy was also reflected within the Quebec wing of the Canadian UAW. Yates argues that 'UAW recognition of Quebec was complicated by the UAW's status as an international union with a Canadian membership which was largely Anglophone. Should the UAW ignore the demands of its Quebecois membership, it would likely find itself the object of nationalist opposition and possibly lose its membership to a Quebec union. ${ }^{48}$ The Canadian UAW leadership sought to find a way to recognize Quebec's status within the union, without losing the support of Anglophone members in the Rest of Canada.

In $1969 \mathrm{McDermott}$ and the president of the local in St. Therese began pressuring the international union to provide Quebec workers the right to union representation in French and to 'simultaneous translations at meetings where French delegates were present.' ${ }^{49}$ The next major development for the UAW Quebec occurred during the 1970 FLQ Crisis when the UAW passed a resolution demanding the revocation of the War Measures Act and its replacement with new legislation intended to deal specifically with the FLQ. This proved to be a crucial move in the UAW's bid for legitimacy among Quebec workers. ${ }^{50}$

In January 1974, UAW members at United Aircraft in Longeueil struck against an employer which refused to accept the Rand Formula. According to Savage, 'When the American leadership of the UAW noticed irregularities in the local union's handling of strike pay, it threatened to pull the plug on the labour dispute. The FTQ came to the defence of the local

${ }^{46}$ Yates, From Plant To Politics, 161.

${ }^{47}$ Larry Savage, “Organized Labour and the Constitutional Question” (PhD dissertation. York University, 2006), Chapter Four, http://www.collectionscanada.gc.ca/obj/thesescanada/vol2/002/NR29523.PDF

${ }^{48}$ Yates, From Plant to Politics, 161.

49 Ibid, 162. 
union.' ${ }^{51}$ The local eventually won the strike, and the lengthy, bitter, and violent dispute had 'such a significant impact on Quebec society that PQ leader Rene Levesque pledged to overhaul the province's labour code to make the Rand Formula mandatory if elected Premier. ${ }^{, 52}$

The strike went a long way to push for more autonomy for Quebec UAW locals within the international union. By the late 1970s, the UAW, along with other pan-Canadian unions such as the USWA, CUPE, and CUPW endorsed Quebec's right to self-determination in order to appease their Quebec memberships. ${ }^{53}$ When the Parti Quebecois formed provincial government in Quebec, McDermott voiced his support for both the PQ and the rights of Quebec workers to determine their own future at Council, using the language of the "two nations" principle to articulate the right of self-determination for Quebec workers. This meeting enshrined the principle of Quebec self-determination in official union policy and signalled the UAW's recognition of the "special status" of Quebec workers within confederation and within the union itself. $^{54}$

As a result, the Canadian UAW adopted a dual Council structure. Savage argues that the Quebec Council 'was established to provide a forum where Quebecois union members could meet and debate political, social, and economic questions specific to Quebec. The CAW recognized that the aspirations of their Quebecois members could not be achieved within the larger framework of a highly centralized national union. ${ }^{55}$ The Quebec Council held its founding meeting in March 1983 and maintained its separate structure when the CAW was born out of the

\footnotetext{
${ }^{50}$ Ibid, 164.

${ }^{51}$ Savage "Organized Labour and the Constitutional Question," 117.

${ }^{52}$ Ibid.

${ }^{53}$ Ibid, 123.

${ }^{54}$ Ibid, 166.

${ }^{55}$ Ibid 230.
} 
UAW in $1984 .{ }^{56}$

\section{Autoworkers and the Crisis of The Keynesian Welfare State}

The 1960s and 1970s saw a number of shifts in the external political and institutional environment and within the union that helped to shape the culture and politics of the Canadian UAW. In 1965 the Auto Pact was signed, shifting the terrain of North American auto production. While the Auto Pact provided a benefit to the Canadian UAW, the 1970s saw a rise in plant closures across North America, which contributed to a reduction in the union's bargaining power. These plant closures were due, in part, to a change in the economic order - it was during this time that Keynesianism began to slide into crisis. It was also during this time that the union became less homogeneous, as new waves of organizing expanded the union's base, giving rise to certain dilemmas around representation.

The Auto Pact between Canada and the United States was signed in 1965 removing tariffs on cars, trucks, buses, tires, and auto parts between the two nations. This greatly benefited American auto manufacturing. Yates outlines how the Auto Pact 'had an immediate impact on the organization of vehicle and parts production in Canada. It allowed corporations to reduce the number of different models produced in Canada and thereby allowed specialization and rationalization of production to achieve continental economies of scale. ${ }^{57}$ It was agreed however that auto production in Canada would not fall below 1964 levels.

With the 1970s came an intensified wave of foreign imports, especially from Japan. These imports took an increasingly larger market share away from domestic autos in North America, leading to decreased production by The Big Three. By 1978, the Big Three were

\footnotetext{
56 Savage "Organized Labour and the Constitutional Question," 229.

57 Yates, From Plant To Politics, 119.
} 
facing losses, and began closing plants. ${ }^{58}$ This would set the tone for the next two decades in the Canadian UAW and CAW - plant closures as a response to shifting production patterns in an increasingly globalized economy. In this context, the UAW agreed to $\$ 403$ million in givebacks - reversals of wage-and-benefits previously bargained - as part of a new three-year contract with Chrysler. $^{59}$

While the UAW was increasingly willing to accept concessions to protect jobs, the Canadian UAW set down a path that would eventually result into the union's "no concessions" policy. In 1978 White had become the Canadian Director, appointing Buzz Hargove as his assistant. The union's no-concession policy came from a round of collective bargaining in which a plant in Kingston was played off of a plant in Quebec, both being asked to give concessions in order to stay open, and the concessions did not come to the attention of the leadership until after the collective agreements were ratified. As part of the aftermath of these concessionary agreements, White approached Bob Nickerson and Buzz Hargrove, intending to introduce a noconcessions policy at the next Council. For the new policy, if a local felt that they couldn't bargain no concessions, they had to get permission of the Canadian leadership to take concessions. $^{60}$

Throughout this period struggles between the left and right in the Canadian UAW continued with the Auto Pact an important point of contention. "Canadians Against the Auto Pact," a union group in Oshawa, argued that the agreement constituted both economic slavery of Canada to the US and the subservience of the Canadian UAW to the international union. The

\footnotetext{
${ }^{58}$ Bob White, Hard Bargains, 143.

${ }^{59}$ Paul Ingrassia, Crash Course: The American Automobile Industry's Road from Glory to Disaster (New York: Random House, 2010), 79.

${ }^{60}$ Hargrove, in discussion.
} 
group, and the larger Canadian nationalist Left within the Canadian UAW, called for a 'made-inCanada industry and a made-in-Canada union. ${ }^{\text {61 }}$

In some cases, the Left's suspicion of the international union - still held by the centreright faction - had proved to be quite accurate. For instance, in 1971, 4000 Canadian Douglas workers had gone on strike. When a settlement was eventually reached in the US, the International union ordered the Canadian strike terminated and withdrew strike pay. The Canadian UAW rank-and-file rejected the US settlement, but the leadership supported the international union. For many Canadian UAW members, this was taken as evidence of the need for greater autonomy for the Canadian region of the UAW. ${ }^{62}$ In many cases, the nationalism on the Canadian left was quite progressive, and linked in with calls for a more militant union which would better articulate the rank-and-file's demands.

The Canadian UAW's partisan political stance changed in the 1960s with the transformation of the CCF into the NDP, with an explicit promise to become the political arm of organized labour in Canada. The Canadian UAW played an instrumental role in the formation of The New Party, being one of the biggest voices from the Canadian labour movement. When the founding convention of the New Democratic Party finally took place in 1961, the Canadian UAW contributed 26 percent of the total contributions made to the New Party Fund. ${ }^{63}$ While the union was an eager participant in the formation of the NDP, almost immediately the union and the party found their relationship strained. The autoworkers expected the labour movement to be 'first among equals' within the NDP, but the leaders of the party 'espoused a pluralist vision of

\footnotetext{
${ }^{61}$ Anastakis, "Between Nationalism and Continentalism," 95.

${ }^{62}$ Yates, "The Internal Dynamics of Union Power," 87.

${ }^{63}$ Ibid, 133.
} 
society in which all interests were equal. ${ }^{64}$ In many ways this signalled a dilution of the close ideological ties between organized labour and the party of labour. In other words, the NDP did not see itself as just a party of labour but rather as a broad-ranging social democratic party interested in developing a cross-class basis of support. While the Canadian UAW was looking for a party of labour, the NDP sought to appeal to all progressive elements in society. This rather rapidly led to the UAW's lackluster commitment to the party.

During The 1970s, an internal conflict developed within the NDP over the direction of the party, and the Canadian UAW became deeply involved in this struggle. The Waffle - the Movement for an Independent Socialist Canada - was a nationalist movement within the NDP that aimed to push the party to the left. One of The Waffle's strategies was to ally itself with radical groupings within trade unions, a strategy which dovetailed with the UAW Left caucus, itself a left-nationalist group. ${ }^{65}$ While the Left of the union was participating with the Waffle, this did not sit well with either the Canadian or International leadership. Dennis McDermott, Canadian director, accused the Left of defying the will of the autoworkers by cooperating with The Waffle, and paralleled the Waffle's interference in internal union affairs with the interference of the Communist Party, thus playing on old, but still simmering Cold War fears of external control of the union. ${ }^{66}$

The struggle between The Waffle and the NDP came to a head in the 1970 NDP convention. A standing vote had left the outcome of the Waffle Manifesto uncertain, and a vote by ballot was scheduled. Various NDP delegates, and at least one MPP, approached McDermott to help prevent the Waffle from winning the vote. He agreed, and instructed the UAW staff to

\footnotetext{
${ }^{64} \mathrm{Ibid}, 138$.

${ }^{65}$ Ibid, 153.
} 
mobilize UAW delegates to vote against the manifesto. The manifesto was narrowly defeated, and the UAW's block voting had helped to ensure its defeat. ${ }^{67}$ By the late 1970 s, with the demobilization of the Left nationalist elements of both the party and the union, the Canadian UAW had become very close to the NDP and the union 'increasingly directed its political education programs towards building greater membership support for the NDP. ${ }^{68}$

During this period, the union was also involved in a key political struggle against wage controls. More broadly, the Trudeau government's embrace of wage controls reflected the crisis of Keynesianism in Canada, and signified a shift away from Keynesian policies towards neoliberal ones. The Anti-Inflation Program of 1975 to 1978 was created to examine newly negotiated collective agreements and to roll back any wage increases that exceeded government guidelines. As Gindin notes, 'The Canadian UAW's response [to wage controls] began with the recognition that wage controls differed from other attacks on working people such as tax increases. Wage controls constituted an attack on the organization itself. ${ }^{\prime 69}$ The union entered into bargaining as if wage controls did not exist: agreements were bargained to exclude recognition of the wage control apparatus.

Yates details the UAW's response to wage control, which involved a three-pronged strategy. The first element, the collective bargaining strategy, was to bargain without consideration of Anti-Inflation Board guidelines. The UAW ensured that union locals refused to sign collective agreements that continue language stipulating that the settlement was subject to

\footnotetext{
${ }^{66}$ Ibid, 154.

${ }^{67}$ Ibid, 169.

${ }^{68}$ Ibid, 188.

${ }^{69}$ Gindin, The Canadian Autoworkers, 176.
} 
AIB approval. ${ }^{70}$ The second and third components of the UAW strategy were part of the political strategy spearheaded by the CLC. The UAW committed itself to the CLC's mass-action campaign, mobilizing Canadian autoworkers in support of demonstrations to oppose government policy. In addition, the UAW supported demands for corporatist restructuring of labourgovernment-business relations.

In the 1980 s, the wage control plan was expanded into the " 6 and 5" program, named for its intended goal of limiting public sector wage increases to $6 \%$ in 1982 , and $5 \%$ in 1983 . The federal government temporarily revoked the right of public sector workers to strike, and unilaterally extended collective agreements for two years. A statutory limit on wage increases of $6 \%$ and $5 \%$ was imposed and any unions who negotiated beyond this limit had their wage increases rolled back. This was initially imposed by the federal government in the hope that provincial governments would follow suit, and they soon did, subjecting provincial employees to similar wage-restraining measures. These anti-inflationary programs of the 1970s and 1980s saw the Canadian state restrict union rights in order to fight inflation, which, in turn, would restore and maintain high levels of profitability for capital.

Finally, a note on membership: The 1960s were characterized by 'the pursuit of new members, the continued appearance of democratic reforms within the union, and the UAW's leadership on social issues built internal union solidarity and pride among workers in the union's position as leader for progressive change. ${ }^{71}$ The Auto Pact led to an expansion of the auto industry in Canada which, in turn, led to a massive organizing drive by the Canadian UAW. The drive's success this brought about an 'infusion of new members into the Canadian UAW.' While

\footnotetext{
${ }^{70}$ Yates, From Plant to Politics, 176 - 177.

${ }^{71} \mathrm{Ibid}, 104$.
} 
the ranks of the union did swell, the organizing drive 'laid the basis for increased internal conflict in the 1970s. UAW membership was no longer as homogeneous as it been in previous years. White collar workers, younger generation of autoworkers, a greater number of women, and a Quebecois membership altered the objective characteristics of the Canadian Region. ${ }^{72}$

These new workers placed demands on the union, including redress for black as well as Quebecois workers from their lack of representation within the UAW itself. Yates argues that 'the lack of historical identity within the union and the different objective characteristics and demands of these autoworkers erected barriers to their mobilization behind existing union goals and their acceptance of union strategies. ${ }^{, 73}$ There was extensive push back in the Canadian UAW however from women and ethnic communities 'who demanded an end to paternalism and exclusion and a right to equal treatment and better representation. ${ }^{, 74}$ In Canada, pressure for inclusion came from the Canadian nationalists on the left of the union. These struggles would set the stage for struggles within the Canadian UAW for more inclusion, as newly organized groups started to seek out a place for themselves within the union.

Heather Jon Maroney describes working-class feminism as 'committed to overall social transformation, its radicalizing dynamic can profoundly alter class politics: broadening workplace struggles, overcoming antagonistic divisions between women and men in the working class, and introducing anti-economist, anti-bureaucratic politics of liberation into existing working-class organization. ${ }^{75}$ Maroney also notes that working-class feminism has been

72 Ibid.

${ }^{73}$ Ibid, 144.

${ }^{74}$ Charlotte A. B. Yates, "Defining the Fault Lines: New Divisions in the Working Class," Capital \& Class 66 (Autumn 1998): 123.

${ }^{75}$ Maroney, "Feminism at Work," 87. 
'weighted down' in its ideological development by reformism in trade unions. ${ }^{76}$ Maroney goes on to develop the idea that trade union feminism has had two distinct stages of development. The first, a 'consciousness raising and mobilizing step, formulates claims from the point of view of women as a special group: the right to work, equal pay, and so on. In agitating for the acceptance of these demands, women have sometimes breached gendered ghetto walls and created a class demand supported equally by, and understood to be in the interests of, women and men. ${ }^{77}$ The development of working class feminism, and trade union feminism, were both seen in the example of the Fleck Strike, a crucial strike undertaken by Canadian UAW workers, who were overwhelmingly women.

The 1978 strike at Fleck, an automobile parts plant, pitted a newly certified Canadian UAW local, overwhelmingly women, against capital, the police, and the state. Management at Fleck hoped an initial display of power would demoralize the strikers, the police supported management, and the Deputy Minister of Industry in Ontario, James Fleck, was an owner of the factory. 'The strikers began to feel that their little union was taking on the whole "establishment:" Fleck, the politicians, and the police. ${ }^{78}$ The women were striking for a first contract, and issues included wages, union security, and working conditions. ${ }^{79}$ As the strike developed it took on a class-politics tone, with the underlying issue being the right to unionize, and it also became a major point of development for working class feminism. As Maroney argues, 'The general potential for radicalization in the interplay of class and feminist forces was manifested in this strike. By its very nature, a strike situation is an intensive consciousness-

\footnotetext{
${ }^{76}$ Ibid.

${ }^{77}$ Ibid, 90 .

${ }^{78}$ J.A. Frank, "The "Ingredients" in Violent Labour Conflict: Patterns in Four Case Studies," Labour / Le

${ }^{79}$ Maroney, "Feminism at Work," 94.
} Travailleur 12 (Fall 1983): 101. 
raising process.' 80

The strikers mobilized union women's committees and groups from the autonomous women's movement for picket line and financial support, which saw the striking women bring 'a feminist perspective to the strike, and more importantly, legitimated the women's movement in the eyes of the strikers. ${ }^{81}$ The strike 'coincided with the creation of an International Women's Day Committee in Toronto. Many of these women organized support for the Fleck strikers by sending delegations and relating the issues at Fleck to the broader questions raised by the Women's Movement. ${ }^{82}$ The Fleck strike popularized a militant feminist ideology, drawing the struggle along both class and sex lines. 'The essence of the working class feminist ideology: women have the right to work; wages are a woman's concern; unionization is a basic weapon; women can find strength from one another in struggle ${ }^{83}$ became guiding principles for how the CAW approached not only women's equality, but equality for all equity seeking groups. The Fleck strike helped define working class feminism, and brought a clear working class feminist analysis to the UAW. 'Militant strike action by women is also an objective challenge to their economic exploitation, their individuation into the illusory privacy of the family, and the ideological construction of women as passive dependants protected by men. At Fleck, the strikers explicitly articulated this challenge. ${ }^{84}$

'After a six month struggle the Fleck women had finally won their first collective agreement. They were proud of their effort. They had developed a sense of solidarity and

\footnotetext{
80 Ibid.

${ }^{81}$ Ibid.

${ }^{82}$ Frank, "The "Ingredients" in Violent Labour Conflict," 101.

${ }^{83}$ Maroney, "Feminism at Work," 94.

84 Ibid.
} 
collective pride and they were now more aggressive in demanding their rights. ${ }^{85}$ The Fleck Strike saw the women strikers not as "others" within the UAW, nor as workers of secondary importance, but of working-class women who were striking for fundamental union freedoms, and challenging the perceptions, both in society and in the union, that women were passive workers who were primarily dependants of men. This militancy greatly informed the position of women within the CAW's activist, and rank-and-file, base. Women's equity within the CAW was seen through a working class politics lens, articulating that the struggle that women had against capital was a working class issue. At the same time, it was clearly articulated that true equity for women meant that they would not be seen as dependents of men.

With White as leader of the Canadian UAW, the Canadian affiliate continued to make substantial moves towards equity within the union's structures. In the mid to late 1970s, White took steps to enhance gender equality with in the Canadian UAW. Complaining about the absence of women in the top union jobs, he embarked on a plan to see more women on the Canadian Council and on the staff of the union. ${ }^{86}$

Neoliberal Consolidation and the Birth of a Canadian Union in the 1980s

The CAW emerged as the crisis of Keynesianism opened the way for neoliberal globalization. One of the main consequences for the union was that the North American auto industry suffered a wave of plant closures, which seriously constrained the Canadian UAW's political options and its power at the bargaining table, to the point where it was occasionally pushed into a purely defensive position. It was during this time, especially surrounding the split of the Canadian UAW from the international union, that the Council became a much stronger

\footnotetext{
${ }^{85}$ Frank, "The "Ingredients" in Violent Labour Conflict," 104.

${ }^{86}$ White, Hard Bargains, 144.
} 
organization. The Council saw a great deal of debate on many issues, and was instrumental in the split. It was also during this time that the Council came into its own as a forum for exchange between the leadership and rank-and-file, and as a way for the leadership to both shape expectations within the union, and organize a coherent defence to the challenges facing the union.

The North American auto industry became increasingly globalized during the 1980 s with the rise in competition from foreign imports. The 1980s was also a period of global economic decline, reflected in falling consumer demand and this further contributed to the crisis of the North American auto industry. The response of the 'Big Three' was to try to increase competitiveness by restructuring production and demanding further concessions from workers. ${ }^{87}$ As a result, the North American auto industry underwent a wave of plant closures and ensuing job losses through the decade. This posed a very real challenge for the Canadian UAW.

The initial response was a spike in union militancy. In the summer of 1980, plant closures were at the top of the agenda at the Canadian Council and resulted in the galvanization of a response to closures from autoworkers. When White stepped up to the podium to conclude the debate, he declared 'if it takes occupations of plants to stop this ... then we'll occupy them. ${ }^{88}$ From there, the Canadian UAW pieced together a strategy based on mass collective action. The union moved away from defensive manoeuvring into a struggle over how the 'national interest' would be defined, and how the union could fight for this interest. ${ }^{89}$

In 1981, following on the heels of concessionary deals in the late 1970s, the Canadian

\footnotetext{
${ }^{87}$ Yates, "The Internal Dynamics of Union Power," 73.

${ }^{88}$ Gindin, The Canadian Autoworkers, 192.

${ }^{89}$ Yates, From Plant to Politics, 203.
} 
Council voted to pursue a no-concessions strategy. ${ }^{90}$ For this strategy to work, the membership had to be mobilized and the Canadian Council provided the basis for mobilization. According to Yates,

'Through the council a plan was formulated for organizing against concessions, and local delegates were instructed to return to their members and lay the groundwork for membership support of the policy. ... While perhaps coincidental, the creation of a separate Quebec Council identical to the Canadian Council and of improved representational structures for women in the union, including the provision of day care at council meetings, could not but help foster unity in the ranks of the union.' 91

One of the first opportunities to test this no-concessions policy came in early 1982, when the Canadian UAW broke ranks with the International union and rejected an early opening of collective agreements with Ford and GM. The issue of concessions was intensified even further when independent parts plants engaged in whipsawing during collective negotiations. ${ }^{92}$

The response by the Canadian UAW to the crisis of the early 1980s - sit-down strikes, no concession policies, and plant occupations - saw the union abandon the politics of 'responsible unionism', and embrace a more militant strategy based on direct and mass action, often in coalition with other unions and progressive groups. ${ }^{93}$ By adopting this militant course of action, 'the Canadian UAW catapulted itself to leadership of the Canadian labour movement and into the limelight of the media.' 94

This decade, and period of heightened militancy, also resulted in a shift in the nexus of power within the Canadian UAW. The Canadian Council became much more important to the union and more power was shifted to the rank-and-file delegates. The Council became the main

\footnotetext{
${ }^{90}$ Ibid, 206.

${ }^{91}$ Ibid, 208.

92 Gindin, The Canadian Autoworkers, 186.

93 Yates, From Plant to Politics, 228.

${ }^{94}$ Ibid, 19.
} 
forum for debate on all issues within the union, took over major responsibility for policy making and strategic planning, and became the central arena for rank-and-file input into and criticism of union policy. The dynamic relationship between the leadership and the rank-and-file also grew through the Council, with the leadership increasingly using the council to test support for leadership initiatives, while the rank-and-file increasingly used the council to hold the leadership accountable for decisions made. ${ }^{95}$ This distinguished the Canadian UAW from many other unions 'where centralised bureaucratic control and expertise replaced union initiatives based on membership activism.... These organizational characteristics worked hand in hand with the Canadian UAW's collective identity to reinforce membership commitment to democratic and local control of the union and to rank and file activism. ${ }^{96}$

The relationship between the NDP and the Canadian UAW grew strained through the early 1980s. After the 1980 federal election, 'the party moved away from its social democratic principles towards a more conservative political image at the same time that the UAW was becoming more politically militant in its own action and more radical in its demands for government action. ${ }^{97}$ The NDP shifted right, tentatively embracing neoliberal policy solutions, and the UAW pulled left, responding to neoliberalism with a wave of militancy. The UAW did, however, contribute both money and staff to the NDP, but its commitment was reduced. ${ }^{98}$ The strain between the union and the NDP would continue to grow through the 1980s, coming to a head in the 1988 election. It was during this decade, however, that the Canadian UAW established itself as a sort of 'left opposition' to the NDP - the union continued to support the

\footnotetext{
${ }^{95}$ Ibid, 242.

${ }^{96}$ Ibid, 243.

${ }^{97}$ Yates, From Plant to Politics, 217.

${ }^{98}$ Ibid, 219.
} 
party, but would frequently criticize it for not being left wing enough.

\section{The CAW Council in Context}

Given the centrality to this dissertation accorded the CAW Council, it is important to conclude this chapter with a reflection on its evolution prior to the CAW's formation. The seeds were planted in the context of a fight between the right-wing of the union, led by President Homer Martin, which had wrested control of the union away from the 'communist dominated' membership, and the Canadian rank and file. Martin's decision to appoint his ally, Charlie Millard ${ }^{99}$ as the Canadian, sparked resistance, which resulted in the formation of a rank-and-file controlled Regional Committee in 1938. The latter met regularly to plan and monitor organization within the Canadian Region. Elections to the three executive positions on the newly created committee were won by the left caucus. ${ }^{100}$ This signified the first step in the long road to Canadian autonomy from the UAW. In 1939, the Canada Council was established. ${ }^{101}$

The Canada Council was established as a rank-and-file control body to act as the parliament of the union. The Canadian director was required to make a report at each council, to keep the membership informed about the activities of the UAW and the decisions of the International Executive Board. This report was subject to debate by the rank-and-file. Initially, the Canada Council met six times a year. ${ }^{102}$ The formation of the Canada Council, its composition of rank-and-file members, and the requirement that the President report to the rankand-file regularly, all signalled a movement towards a more autonomous Canadian UAW and helped created the potential for the later movement to the CAW. The Council would become a

\footnotetext{
${ }^{99}$ Gindin, The Canadian Autoworkers, 27.

${ }^{100}$ Ibid, 28.

101 Ibid, 68.

102 Yates, From Plant to Politics, 31.
} 
very important forum for both debate and for the passing of information and strategy between the leadership and the rank-and-file.

As noted, the Council has been frequently described as 'the Parliament of the union.' ${ }^{103}$ It was the primary deliberative body in the CAW. It convened regularly throughout the year, the weekend long meetings attended by delegates elected through locals. The CAW President and staff made written reports to the Council, with the President's report presented orally to the body of the council. The Council allowed for the membership to hold the President, and by extension the National Executive Board, accountable and it allowed the President and NEB to get rankand-file input on campaigns and decisions. While the Council did exist as a medium for the leadership to 'report to the local leadership as to what's going on at the National level,' 104 the form and level of debate, and the effectiveness of the communication between the rank-and-file members and the leadership has been criticized.

The Council served as an important forum for political debate within the union. The Council provided a forum for 'dissident autoworkers to coordinate their strategy and program and to mobilize region wide membership support. ${ }^{, 105}$ It was at the Council where the various elements of the left within the Canadian UAW formed the Left caucus, which developed a leftnationalist ideology as the basis for unity. ${ }^{106}$ The Left caucus, which brought together communists, left NDP members, and other left leaning UAW members, had formed, in part, in reaction to the bureaucratic consolidation of undertaken by UAW President Reuther. ${ }^{107}$ The

${ }^{103}$ Tim Carrie, in discussion with the author, July 2013; Mike Shields, in discussion with the author, August 2013. Other interviewees, including Malcolm Allen, Sam Gindin, Herman Rosenfeld, and Carol Phillips all discussed the Council as a deliberative body.

${ }^{104}$ Carrie, discussion.

${ }^{105}$ Yates, From Plant to Politics, 149.

${ }^{106}$ Ibid.

${ }^{107}$ Sam Gindin, in discussion with the author, August 2013. 
Canadian nationalism of the Left caucus was rooted in a desire to have the Canadian economy be independent, not dominated by American imperialism. ${ }^{108}$ It was at the Council that the early Left caucus mobilized support for an independent Canadian economy. The Council also served as a forum to advance equity politics. In the very early days of the CAW, the Council voted to change their own bylaws to guarantee that at least one of the positions on the Council executive was held by a woman. ${ }^{109}$

In the days before the Canadian UAW split from the international union, the Council would meet six times a year, and the Left was particularly active in meeting members and mobilizing them. ${ }^{110}$ The Left caucus was well organized in the Canadian UAW, anchoring the Canadian union to the left. The caucus was taken as a serious threat by the leadership of the union. $^{111}$

The new CAW Council would differ from the UAW's Canada Council in important respects. Yates argues that the executive of the national union and the Council became structurally intertwined, leaving open the possibility of greater leadership control over the decisions of the Council, and reducing the role of the Council as a site for articulating the internal opposition to the leadership. This, combined with White's successful cooptation of opposition to his leadership, reduced the Council's importance. ${ }^{112}$

Communication at the Council was two-way, albeit unequal. The President would present recommendations and resolutions to the council for debate. After debates, votes would be held, and in many cases, the vote would be unanimous or very close to unanimous. Malcolm

\footnotetext{
108 Anastakis, "Between Nationalism and Continentalism": 110.

${ }^{109}$ November 1987 Council minutes.

${ }^{110}$ Gindin, discussion, 2013.

${ }^{111}$ Carol Phillips, in discussion with the author, August 2013.

112 Yates, From Plant to Politics, 251; Yates, “The Internal Dynamics of Union Power:” 101.
} 
Allen, a frequent delegate to the CAW Council argued that 'the reality is its guided democracy.' 113 One of the reasons there generally was little dissent was that the Council was viewed 'a place to be seen.' For members who had aspirations in the CAW - for leadership positions, or staff jobs - the CAW Council provided a main opportunity to be noticed by the leadership. This meant that there was a 'quieting effect' on debate, as 'you didn't disagree with the folks who picked you for staff.' 114

In the history of the CAW, some of the members at Council who engaged in dialogue with the leadership, frequently critiquing or criticising the position of the leadership, would sometimes end up appointed to staff. This suggests that a small degree of critiquing the position of leadership could advance one's position in the union, but being overly critical of the leadership meant that one would be isolated and ignored. Once appointed to staff, these members would automatically become part of the Administrative Caucus, which would allow the union leadership a greater degree of control over these members. Thus, mid-tier activists could find themselves on staff with just the right amount of critical dialogue with the leadership, and one of the effects of this was that the leadership had, in the end, an easier time controlling these members.

In some cases, the position of the leadership was modified through debate, other times a plan was expanded following rank-and-file input, and frequently, the Council served as a forum to allow the leadership to clarify positions to a rank-and-file that may be sceptical or confused. This debate, deliberation, and policy formation and modification gave 'the National President the

\footnotetext{
${ }^{113}$ Malcolm Allen, in discussion with the author, June 2013. Sam Gindin, in discussion, also noted that there was not a great deal of dissent at the council, arguing that delegates would often vote for a measure publically, but later criticize the decision in private.

${ }^{114}$ Ibid.
} 
ability to publicly take a position without being concerned that he's out of touch with local leadership and membership.' ${ }^{115}$ Once the Council endorsed a decision, it was 'expected' that the Council's decisions would be carried out at everybody's home local. ${ }^{116}$ This allowed national policies to be debated by the rank-and-file, and implemented after debate - rather than have national policies simply implemented by the national union, without input from the locals. The Council acted as a vehicle for the leadership to get authorization from the rank-and-file to carry out its proposed plans of action. ${ }^{117}$ The two-way communication at Council ensured that the national leadership did hear the voices of the rank-and-file activists, however, Council acted primarily to get the mid-tier activists to support the plans decided by the National executive.

As the CAW grew, the Council would become more subservient to the leadership, although it remained a mechanism for accountability from CAW leaders. Through the entire existence of the CAW Council, the President never actually lost a vote and only came close to losing a vote twice. The first came in 1992, shortly after Bob White left as president of the union and the council executive presented a recommendation to purchase White a cottage at the Port Elgin education centre. ${ }^{118}$ The second close debate involved the CAW's position on gun control, described at length in Chapter four. ${ }^{119}$ Hargrove led the council through 'about five different debates on gun control,' and managed to win each one, each time with a thin majority. ${ }^{120}$

As time went on, more guest speakers were invited to the council and there was less

${ }^{115}$ Carrie, discussion.

${ }^{116}$ Chris Buckley, in discussion with the author, July 2013; Carrie, discussion.

${ }^{117}$ Allen, discussion.

${ }^{118}$ After lengthy debate, the body was able to get the leadership to change its position - something that was a rare occurrence. The union would build a cottage, which White would get to use indefinitely, but the cottage would remain CAW property.

${ }^{119}$ The votes on gun control were the closest votes the CAW ever had. The pro-gun control position was championed by Hargrove, but many members opposed the leadership's position.

${ }^{120}$ Buzz Hargrove, in discussion with the author, July 2013. 
debate about the President's report. During White's leadership, and the early years of Hargrove's presidency, long sections of the report were subject to debate. By the end of Hargrove's leadership, and through the Lewenza years, there was almost no debate on the President's report. ${ }^{121}$ In fact, by the time Lewenza became president of the union, there were fewer recommendations from the President's report discussed at Council. ${ }^{122}$ This decline in debate coincided with President Hargrove's decision to stop submitting written reports to the council. Instead the report would be presented orally, then transcribed and sent to delegates who attended the Council. Gindin argues that once the report stopped being written 'it's off the cuff. And then you can't really challenge it, because he can always fudge it anyways, and then you only get it like written up afterwards.' ${ }^{123}$

By the late 2000s the relationship between leaders and the mid-tier activists at Council had come to favour the leadership. Herman Rosenfeld relayed a story that nicely encapsulated the state of the CAW Council at that time: 'I was talking to Bruce [Allen, activist and vice president from CAW 199] at a rally or something, and he said, "You'll notice as time goes on I become the only person who speaks out against the leadership," and I thought he was exaggerating, until I got to the mid-2000s, and Bruce was the only one who'd speak out against the leadership.' ${ }^{124}$ While rank-and-file delegates to the council still have concerns and criticisms of the leadership, by the late 2000 s, there was little critical undercurrent to these concerns. It had become, at best, a way for people to 'sound off.' 125 Rosenfeld's comments were indeed supported by the minutes examined during the study: by the late 2000s, Bruce Allen was the only

${ }^{121}$ This was noticed through the archival research, and was later confirmed in discussion with Tim Carrie and Malcolm Allen.

${ }^{122}$ Carrie, discussion.

${ }^{123}$ Gindin, discussion, 2013.

${ }^{124}$ Herman Rosenfeld, in discussion with the author, August 2013. 
voice to criticize the leadership of the CAW. Issues which were once contentions, including electoral strategy, were no longer subject to great debate on the council floor. By the very late history of the CAW Council, there was almost no dialogical communication between the mid-tier activists and the leadership at Council, with leadership exerting a great deal of control over the direction and policy of the union. This suggests that as time went on, the Council had less of a potential to an important forum for class formation.

One of the ways the leadership exerted control and direction over the CAW Council was through the Administrative Caucus, which was closely intertwined with the inner workings of the Council and Council elections. The Administrative Caucus, which survived the transition to the CAW, had formed part of the old Canadian UAW, acting as the union leadership's caucus and a counterpart to the Left caucus. As one informant noted, the Administrative Caucus was formed on the principle that 'the leadership has a core of people throughout the union that does what it tells them to do. That discipline behind them is a critical discipline, and that's how they rule.' 126 The Administrative Caucus is, at its core, a reflection of Michels' observation of organizations where 'a social group which had secured control of the instruments of collective power would do all that was possible to retain that control., ${ }^{127}$

The Caucus' main purpose pertains to elections at the CAW Council. Before an election for any position at Council, the Administrative Caucus would meet, determine a slate for the election, and then run that slate on the floor. Members of the Administrative Caucus were expected to support the slate, vote for the slate, and were forbidden to run against the slate. While the slates

\footnotetext{
125 Ibid.

126 Ibid.

${ }^{127}$ Robert Michels, Political Parties: A Sociological Study of the Oligarchical Tendencies of Modern Democracy, trans. and ed. Eden and Cedar Paul (Kitchener: Batoche Books, 2001), 230.
} 
were theoretically decided at the caucus, the union's leadership had 'already decided the slate' and presented it to the caucus. ${ }^{128}$ All election slates are determined by the leadership and presented to the Caucus, where they are then endorsed and taken to the Council floor. Carol Phillips, the assistant to Bob White and Buzz Hargrove, had planned on running for the office of Secretary-Treasurer. When Phillips announced she was going to run she 'was told I couldn't, because the administrative caucus would decide who the candidate was going to be, the NEB and the administrative caucus.' ${ }^{129}$ Phillips adds that anybody who runs against the leadership without the support of the Administrative Caucus is 'isolated as a wingnut.' 130

The Administrative Caucus was not limited to making decisions about the composition of the executive of the Council, it also took decisions about the national leadership. At the April 1991 Council, Bob Nickerson announced his retirement as national secretary-treasurer. Bob White told the Council at this meeting 'I just want to say that we have called an administrative caucus for immediately upon adjournment here and we will discuss that. ${ }^{, 131}$ When White left the CAW to take the presidency of the CLC, in his farewell speech to the CAW Council, he told the delegates 'And my guess is, without predicting the results today, I think we'll end up electing two rank and file local union loaders to the National Executive Board, and one probably full-time member of our staff.' 132

Over the course of the research, sixteen elections were called at the CAW Council, constituting 54 positions on the CAW Council executive. All 54 of these positions were

\footnotetext{
${ }^{128}$ Rosenfeld, discussion.

129 Phillips, discussion.

130 Ibid.

${ }^{131}$ April 1991 Council minutes, 5.

132 June 1992 Special Council, Bob White’s Speech, 28.
} 
acclaimed. ${ }^{133}$ In virtually all cases, the National President would call for an administrative caucus meeting just before the Council broke for lunch, and after the lunch break, the elections would be held. For example, in April of 1997, Hargrove announced at the end of the day "I would like to remind new delegates that we have an Administration Caucus, we have an election coming up tomorrow and we would appreciate if people would stay back and be part of this decision." On the following day, two members were acclaimed to positions on Council. ${ }^{134}$

As will be discussed in subsequent chapters, however, the CAW had a very real commitment to equity which included caucuses for equity seeking workers. These caucuses would meet at every Council, allowing these delegates to mobilize behind recommendations and resolutions. Heather Jon Maroney has argued that 'trade union feminists, especially union staff, are not only subject to the usual pressures of bureaucratic and reformist integration of normalized union practice, but must also bear the brunt of sexism inside the unions. ... The task has been complicated by the existence of real resistance among rank and file women, let alone men, to sexual and cultural issues.' ${ }^{135}$ The Council provided an important forum for CAW feminists to organize through caucuses - the proximity to the leadership at Council allowed for these activists to impress the importance of equity on the union's leadership. During his time as national president, Buzz Hargrove would attend each caucus, whenever invited. ${ }^{136}$ To some extent this

133 The elections were held in December 1985, November 1987, August 1990, December 1993, December 1994, September 1995, April 1997, December 1997, August 1999, April 2001, December 2002, April 2003, December 2005, April 2006, April 2007, and December 2007. In only one case during the length of my study was an election - one where not all candidates were acclaimed - actually held. The power of the Administrative Caucus was on display for this election. In August of 1993 elections were held for all positions on the CAW Council. The president, vice president, secretary-treasurer were all acclaimed. Four candidates ran for three trustee positions. All the locals present voted in block form for the three candidates endorsed by the Administrative Caucus, until the fourth candidate - not supported by the Caucus - withdrew from the election on the floor, resulting in the three backed candidates taking their position.

134 April 1997 Council minutes, 44.

${ }^{135}$ Maroney, "Feminism at Work," 91.

${ }^{136}$ Hargrove, discussion. 
shows in the way that the caucus allowed for two way communication between leadership and the rank-and-file. Hargrove's position on equity was partially driven by his participation in these caucuses.

\section{Conclusions}

The seeds of the CAW can be seen in the history of the Canadian UAW. The struggles over the political direction of the union were played out in the decades from the founding of the UAW to the eventual formation of the CAW. The union was long controlled by a centre-right faction, but the Left Caucus providing lengthy and sustained opposition. Much of the Left politics and calls for militant rank-and-file action were couched in the language of Canadian nationalism - the Left suggested that an independent Canadian union would have better control over its own destiny, and over the direction of the Canadian economy. The shadow of Canadian nationalism would be cast long over the CAW in the years to come.

The early Canadian UAW was home to factional struggles on the political left, especially around electoral politics. Social democrats, communists, and Liberal party supporters all vied for control of the union. As the union developed, these currents were still present, but the political direction coalesced around social democracy. The Canadian UAW played an important role in suppressing the left leaning Waffle movement in the NDP, but would soon become a left critic of the party. By the time the Canadian UAW split and formed the CAW, the relationship between the union and the party was strained, with the union feeling the party had shifted to far to the right.

The Canadian UAW, and the International UAW itself, had also established itself as a leader in equity bargaining in the labour movement. The UAW was challenging issues, and making gains for equity seeking groups, long before much of the Canadian labour movement 
was doing the same. The early struggles for gender equality and equity for racialized workers established the Canadian UAW as a socially progressive union, which recognized that working class politics must incorporate the politics of equity and a broad vision of social justice.

Over the decades from the founding of the UAW to the founding of the CAW, the Canadian UAW became increasingly militant in comparison to its American cousins. While the International UAW was willing to cooperate with management and would agree to concessions, the Canadian UAW adopted a no-concessions stance, and would engage in militant direct action to take redress from the employer. In no small part was this militancy a driving factor towards the split. This increased militancy, the commitment to equity, and the participation in a broader left wing social-democratic agenda all helped place the Canadian UAW on the left of the labour movement in Canada, along with CUPE and CUPW. On December $11^{\text {th }}, 1984$, the Canadian Council agreed, with a vote of 346 to 4 , to establish a Canadian union: the CAW was born. ${ }^{137}$

${ }^{137}$ Gindin, The Canadian Autoworkers, 214. 


\section{Chapter Three: Free Trade, Plant Closures, and The Fight-Back Strategy}

\section{Introduction}

As we will see, the story of the CAW's political engagement, told in chapter five, is connected to the story of the decline of manufacturing in North America. In this chapter, the focus however is on the union's workplace response to the growing number of plant closures, precipitated by a series of free trade agreements beginning in 1988. The CAW responded to the challenge in various ways, with changes over time in its strategic orientation. More specifically, the automotive sector's decline prompted the union to begin to organize and merge with other unions in sectors outside its traditional auto base. As plant closures spread and the Canadian manufacturing footprint declined, the union became more inward looking, concerned more with the short term strength of the auto sector than with the broader interests of the working class. One of the union's main strategies in the face of plant closures was to maintain existing union density through mergers rather than new organizing initiatives. The CAW became more sectorally heterogeneous, and while the new members provided the union a much-needed influx of dues and other resources, auto remained central to the union's political direction due, in no small part, to the industry's importance to the Canadian economy. The auto industry 'provides so many jobs, provides so many skilled jobs, high-paying jobs, and, and, before we merged with the air traffic controllers, it was the highest-paid part of the union... that paid the most dues to the union.' ${ }^{1}$ Protecting the auto industry thus remained one of the union's central goals.

The auto plant closures changed the nature of collective bargaining. The union used to be able to use its relative strength in the auto sector to bargain for new language in collective

\footnotetext{
${ }^{1}$ Buzz Hargrove, in discussion with the author, August 2013.
} 
agreements, which it would then try to export to collective agreements in other sectors. For example, the Women's Advocate Program, detailed in chapter four, was first negotiated in the auto sector. As the auto sector declined, however, the CAW was forced into a more defensive position. While initially it sought to maintain its position, it subsequently focused on keeping jobs for its members, even in the short term.

The CAW did not hesitate to use contentious political tactics like worksite occupations and sit-down strikes to help further its political, and collective bargaining, agendas.

Nevertheless, as this chapter argues, there was a gradual decline in militancy linked to the overall decline in union strength precipitated by neoliberalism. In short, the CAW became more hesitant about - although it did not completely eschew - using its economic strength for political projects. As Gindin argued, unions as sectional organizations can focus on growing their own membership base, but not really organizing members as effective social agents. ${ }^{2}$ This was reflected in the the CAW's increasing hesitancy to use its economic strength for political projects. The type of a gradual decline of militancy and a more inward looking nature has implications for class formation: as the union became more defensive, its political orientation did not always encompass a broader working class politics outside of the union.

This chapter begins a discussion of how deindustrialization and plant closures affected the union, and then goes on to examine the union's macro collective bargaining agenda and outcomes in an era of deindustrializaiton, plant closures, and free trade. Underscoring the importance of free trade as an object of union struggles, the chapter then turns to an account of the CAW's struggle against free trade. As noted in chapter one, free trade can be seen as one of

\footnotetext{
${ }^{2}$ Sam Gindin, "Up Against The Wall: The Political Economy of the New Attack on the Canadian Labour Movement: A Reply to Andrew Jackson," Just Labour: A Canadian Journal of Work and Society 20 (Summer
} 
the hallmarks of neoliberalism and economic globalization. Capital became increasingly global and barriers to trade, such as tariffs, were systematically dismantled, leading to, among other things, downward pressure on wages in core industrial sectors. The chapter details the organizing and mergers the union went through in order to bolster its ranks. It argues that keeping union density high became one of the union's paramount concerns.

\section{Deindustrialization and Plant Closures}

Since the 1970s deindustrialization and plant closures have become the norm for the North American manufacturing sector. Beginning in the 1970s and 1980s, millions of workers in the United States lost their jobs to plant closures or permanent layoffs. Manufacturing job losses were particularly severe in steel, textiles, apparel, and auto. ${ }^{3}$ Milkman outlines the direct connection between plant closures and the decline of auto union power: 'as the domestic industry's growing excess capacity led to wave after wave of plant closings and layoffs in the 1980s, GM, Ford, and Chrysler launched a new campaign to discipline labor by playing one plant off against another.' ${ }^{4}$ In Canada, the 1980s and 1990s saw waves of plant closures and shifts of manufacturing work from Canada to the low-wage U.S. south and the Global South. ${ }^{5}$ As Yates and Leach note, 'these trends were reinforced by the economic restructuring that accompanied the negotiation of free trade, first with the United States in 1998 and then, in 1993, an expanded arrangement that included Mexico. ${ }^{6}$ As a result of the changes, between 1989 and

2013): 65 .

${ }^{3}$ Ruth Milkman. Farewell to the Factory: Auto Workers in the Late Twentieth Century, (Berkeley: University of California Press, 1997) 93.

${ }^{4}$ Ibid, 87.

${ }^{5}$ Charlotte Yates \& Belinda Leach, "Industrial Work in a Post-Industrial Age," in Work in Tumultuous Times: Critical Perspectives, Vivian Shalla \& Wallace Clement, eds, (Montreal \& Kingston: MQUP, 2007), 164.

${ }^{6}$ Ibid. 
1992, 7000 plants closed down and Canada lost 300000 manufacturing jobs. ${ }^{7}$
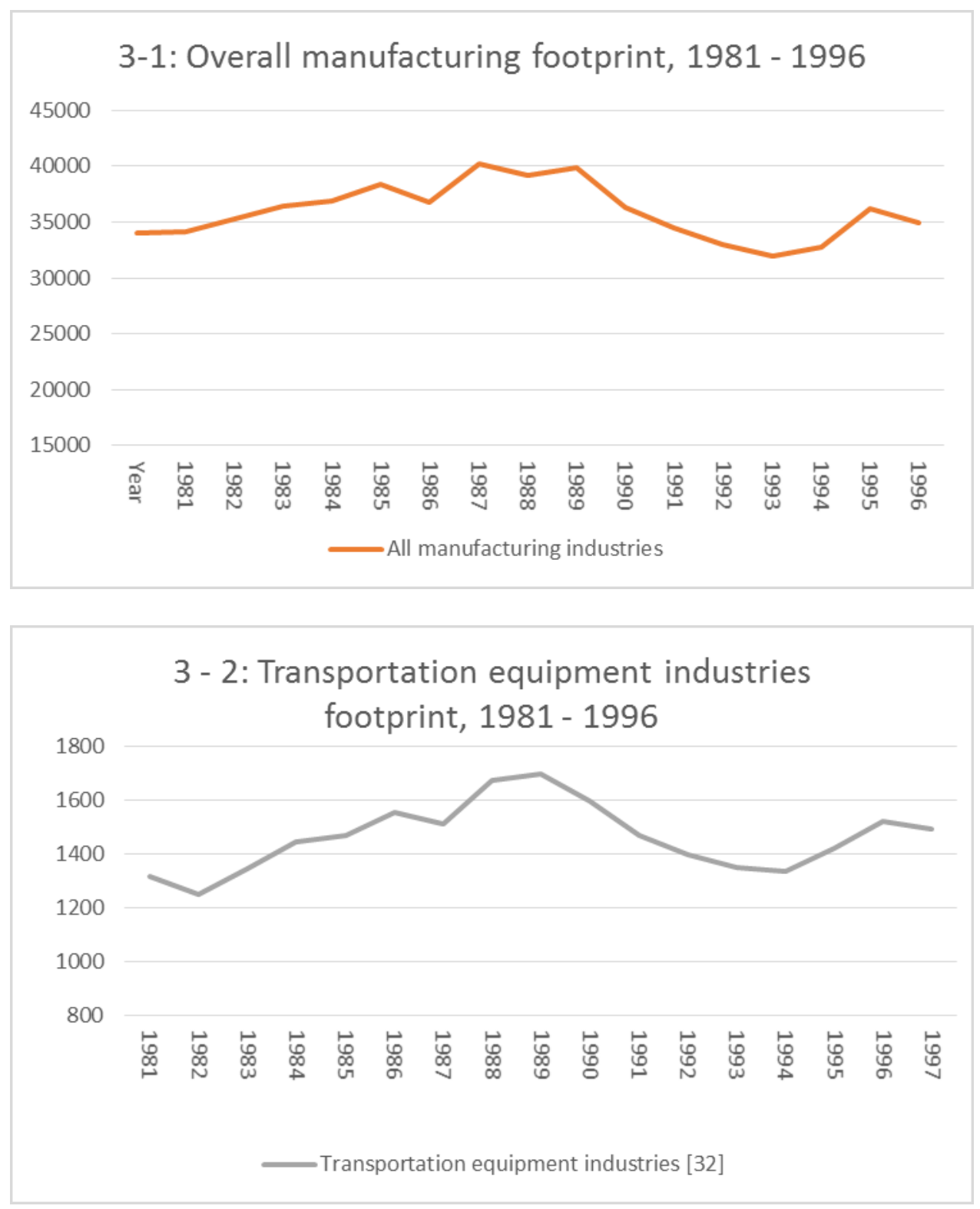

Charts 3-1 and 3-2 show the decline in the overall manufacturing footprint, and the transportation equipment footprint, respectively. ${ }^{8}$ As the charts show, there was a decline in manufacturing in Canada following the adoption of free trade in 1988, with a small uptick in

\footnotetext{
${ }^{7}$ Ibid, 171.

${ }^{8}$ Source - statistics Canada, CANSIM database, Table 301-0001 - Manufacturing activities, by Standard Industrial Classification, 1980 (SIC), annual (dollars unless otherwise noted); accessed 03 October 2014. Note, this
} 
1993 and 1994, followed again by a decline. Charts 3-3 and 3-4 show the number of persons employed in manufacturing, overall, and transportation manufacturing. ${ }^{9}$ There was a sharp decline in overall manufacturing following the conclusion of the free trade agreement, followed by an increase in the late 1990s. A similar pattern emerged in transportation manufacturing.
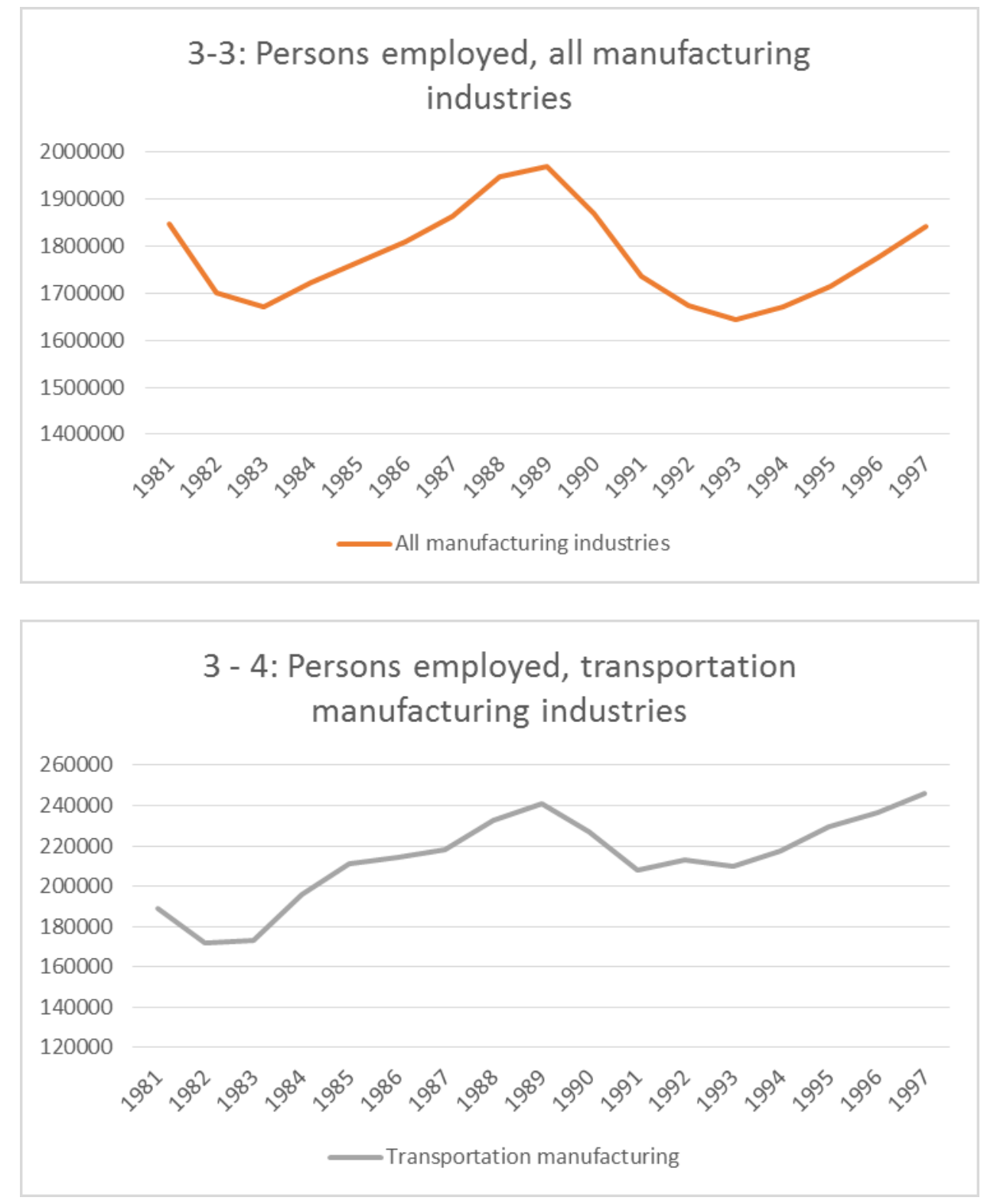

The small upturn in plants and employment in manufacturing obscures some in-depth 
processes within manufacturing capital. As Albo notes, neoliberalism has seen 'capital disperse labour processes and organizational components spatially ... this allows for 'just in time' production of automotive parts. ... this flexibility, with workers carrying a huge burden for this through increased precarious working hours and pay - allows firms greater economies of scope. ${ }^{10}$ Essentially, the jobs created in the wake of free trade were more precarious and much lower paying than traditional jobs in automotive and automotive parts manufacturing. In their study of the Canadian automotive industry after NAFTA, Kumar and Holmes show that there was a 'significant shakeout of the auto parts sector between 1989 and 1992 . Virtually all of the auto industries experienced a reduction in the number of establishments between 1989 and 1991.'11 They note that while the auto industries saw a financial recovery between 1991 and 1996, this was not accompanied by an increase in workplaces. ${ }^{12}$

To CAW members, the major consequence of free trade was deindustrialization and plant closures, which destroyed jobs while simultaneously eroding the union's economic base. In this context, Briskin cautions, 'declining membership and dues have also taken their toll on equality work inside unions. ...Women's and other equality programmes are often seen as expendable. ${ }^{13}$ Plant closures hit the union in waves. Accoding to Lewenza, 'the worst was probably in the first years after the Canada-US free trade agreement, '89, but especially 1991, '92.' ${ }^{14}$ In the decade

${ }^{9}$ Ibid.

${ }^{10}$ Greg Albo, 'The "New Economy" and Capitalism Today,' in Interrogating the New Economy: Restructuring Work in the 21st Century, edited by Norene J Pupo \& Mark P Thomas, (Toronto: University of Toronto Press, 2010), 13.

${ }^{11}$ Pradeep Kumar \& John Holmes, "The Impact of NAFTA on the Auto Industry in Canada" in The North American Auto Industry Under NAFTA, edited by Sidney Weintraub \& Christopher Sands, (Washington: The Centre for Strategic and International Studies, 1998) 120.

12 Ibid.

${ }^{13}$ Linda Briskin, “Austerity, union policy and gender equality bargaining," Transfer 20 no. 1 (2014): 120. There seems to be little evidence uncovered from my research to suggest that the CAW treated equity programs as expendable during the contraction of their membership base.

${ }^{14}$ Ken Lewenza, in discussion with the author, July 2013. 
following its split from the UAW, the CAW was faced with 'the widespread introduction of a startling array of new technologies and a rash of corporate restructuring. All this resulted in workplace closures and the loss of tens of thousands of jobs. Between 1985 and 1995, the CAW had to deal with 250 workplace closures affecting 28000 workers. ${ }^{15}$

The first serious discussion of plant closures came less than a year after the CAW's formation, when news came that two GM plants might close. ${ }^{16}$ The first closure occurred in Thorold, where a Hayes Dana plant downsized its workforce from 900 employees to 200 while the company planned on expanding into non-unionized workplaces. ${ }^{17}$ A minor wave of plant closures in 1987 saw six plants - Cadbury Chocolate, Hayes Dana, Kingsbury Machine, Advance Power, Etatech, Wabco - all close by the end of the year. ${ }^{18}$ The union initially sought to address the problem at the bargaining table. Bargaining committees were urged to negotiate language to protect pensions, to limit plant closures, and to protect against a movement of the plant 'down the road.' 19

Following another series of plant closures in 1988, the union re-dedicated its commitment to finding ways to resist them. White urged all locals to consider bargaining hard, even under the threat of 'complete closings' to make sure 'a new buyer doesn't get a much different contract than the former owner.' ${ }^{20}$ There was a major wave of plant closings in the wake of the 1988 free trade agreement, of which at least six were linked directly to the signing of the free trade

\footnotetext{
${ }^{15}$ Buzz Hargrove, Labour of Love: The Fight to Create a More Humane Canada (Toronto: McFarlane Walter \& Ross, 1998), 112.

${ }^{16}$ September 1986 Council, President's report, 11 - 12.

171987 Council, President's report, 12.

${ }^{18}$ June 1987 Council, President's report, 16; December 1987 Council, President's report, 28.

${ }^{19}$ December 1987 Council minutes 39.

${ }^{20}$ October 1989 Council, President's report, 13 - 14.
} 
agreement. Many more were to follow. ${ }^{21}$ By 1990, sales of domestically produced cars had dropped dramatically, leading to more plant closures $^{22}$ and by August, 42 CAW organized workplaces had closed. ${ }^{23}$

By the middle of 1991 North America was facing a deep economic recession, which brought in its wake more plant closures, with over eleven new closures that year. ${ }^{24}$ The union's main course of action was to lobby the NDP provincial government to introduce legislation on plant closures. $^{25}$ The response was not dissimilar a year later when seven more workplaces (representing 1058 workers) closed and GM announced plant closures amounting to 2864 jobs. $^{26}$ The debate at council was limited to strategies to lobby elected officials to limit import sales and to introduce plant closure laws. ${ }^{27} 1992$ was a particular tough year for the union, with plant closures in auto parts, aerospace, fisheries, airlines, and electrical sectors of the union, amounting to over 4000 jobs in one year alone. ${ }^{28}$ The union's primary response was to make them a 'major issue in collective bargaining ${ }^{29}$ yet it was never clearly spelled out how this might be done. The 1990s saw CAW workplaces continue to shed thousands of jobs each year. The CAW squarely laid the blame of job losses at NAFTA. ${ }^{30}$

As the new century opened, the situation worsened as the 9/11 terrorist attacks led to a massive downturn in the worldwide airline industry, resulting of over 1200 layoffs of CAW

\footnotetext{
${ }^{21}$ February 1989 Council, President's report, 19; September 1989 Council, President's report, 13.

${ }^{22}$ February 1990 Council, President's report, 15.

${ }^{23}$ August 1990 Council minutes, 1.

${ }^{24}$ April 1991 Council minutes, 2.

25 Ibid, 65.

${ }^{26}$ April 1992 Council, President's report, 15 - 17.

27 April 1992 Council, 128.

${ }^{28}$ August 1992 Council, President's report, 2, 8; December 1992 President's report, 1.

${ }^{29}$ December 1992 Council, President's report, 6.

${ }^{30}$ April 1996 Council, President's report, 15.
} 
members working in airlines. ${ }^{31}$ In the years following 9/11, the union saw 13000 jobs lost in aerospace, and thousands of additional jobs lost which were indirectly tied to aerospace. ${ }^{32}$ The early 2000s also saw layoffs in the auto sector - still the key sector for the CAW - with over 3500 layoffs in the parts sector as well as major layoffs in hospitality industries hit hard by $9 / 11 .^{33}$

The next wave of layoffs occurred in the mid-2000s. Retail-wholesale was hit hard when Loblaws closed down 43 stores. $^{34}$ The auto-parts sector, facing intense competition from offshore manufacturing, saw over 2500 jobs lost in 2006. ${ }^{35}$ Between 2005 and 2006, over 320 000 jobs in the manufacturing sector in Canada - not all CAW jobs - were lost in the economy. ${ }^{36}$ The CAW formulated a fight-back strategy that involved holding information forums in comminutes about job losses. Beyond this, the CAW sought to work with the CLC to hold a National Day of Action on job losses in the manufacturing sector. ${ }^{37}$

By 2009 the CAW had lost more than 40000 automotive jobs, in no small part due to free trade as a $\$ 15 \mathrm{~B}$ auto trade surplus had become a $\$ 14 \mathrm{~B}$ auto trade deficit. By this point the Big Three were barely ranked among the top 10 auto producers globally. ${ }^{38}$ The CAW also lost over 3000 more members from Air Canada ${ }^{39}$ and plant closures were announced in auto parts, appliance manufacturing, steel, aero manufacturing, and wholesale. ${ }^{40}$ By 2007 the union had lost 250000 manufacturing jobs in four and a half years. It was estimated that the union was shedding, on average, 150 manufacturing jobs a day. The CAW did, however, recognize that

${ }^{31}$ December 2001 Council, President's report.

${ }^{32}$ December 2004 Council minutes, 72.

${ }^{33}$ Ibid.

${ }^{34}$ December 2006 Council, President's report, 2.

${ }^{35}$ Ibid, 8.

${ }^{36} \mathrm{Ibid}, 15$.

${ }^{37}$ December 2006 Council minutes, 47.

${ }^{38}$ Buzz Hargrove, Laying it on the Line: Driving a Hard Bargain in Challenging Times (Toronto: HarperCollins, 2009), 230. 
this was a structural issue and not 'a recession. This isn't a temporary downturn in which we're going to come out of this. ${ }^{41}$ Yet despite recognizing that plant closures were a structural issue in the economy its attention was still mainly focussed on awareness and electoral politics.

\section{Collective Bargaining}

The issue of concessions runs deep in the history of the CAW. As the introduction to the dissertation noted, the story of the CAW told here is bookended by concessions. The CAW broke away from the American UAW when the Americans were willing to take concessions that the Canadians were not. Indeed, in the early days of the CAW, a refusal to take concessions was one of the union's core principles. One of the earliest struggles for the new Canadian union was a fight against concessions for its members working at airlines. ${ }^{42}$ Yet in 2010, at the height of the Great Recession, the union signed a massive concessionary agreement in order to secure short term automotive production.

Of course, one of a trade union's basic purposes is to collectively bargain with the employer. The CAW has used collective bargaining at times as a political tool - to fight plant closures, to advance a socially progressive agenda, and to better the lives of CAW members and the broader working class. This section looks at the union's collective bargaining agenda as a response to plant closures. Particular attention is paid to the issue of taking concessions: rolling back language in collective agreements, taking cuts to compensation, or expanding management rights. Understanding why the CAW eventually accepted concessions at the bargaining table is important to understand the shifts within the union.

\footnotetext{
${ }^{39}$ December 2003 Council, President's report, 5.

${ }^{40}$ December 2003 Council, President's report.

${ }^{41}$ April 2007 Council, President's report, 25.

${ }^{42}$ Hargrove, Labour of Love.
} 
After breaking from the UAW over the issue of concessions, the union had almost immediately to continue to fight concessions. CAW members at CanCar in Thunder Bay went on strike over a proposed plant closing. The strike lasted three months and was successful in driving concessions off the table and keeping the plant open. ${ }^{43}$ At the same time that the union was fighting concessions, it was also attempting to expand collective agreements in monetary and non-monetary areas and the Big Three remained central to the union's collective bargaining agenda. The relative economic strength the CAW enjoyed at the bargaining table with auto producers allowed it to win gains in auto and then 'carry that into our round of talks with the auto-parts industry, and then the agricultural implements industry, the aerospace industry, and so on. There might be some differences in detail, but the general thrust is the one we set with the auto companies. ${ }^{44}$ In the late 1980 s the CAW's priorities were pensions, income security, child care, and affirmative action. ${ }^{45}$ All of these areas, but especially affirmative action, were eventually won at the bargaining table with the Big Three and later expanded into other collective agreements.

The union also sought to use economic strength at the bargaining table to protect CAW jobs in the long term. In the wake of the free trade agreement and with talks of NAFTA ongoing, the union made negotiating to 'limit the corporations' rights on outsourcing, and outside and inside contracting. ${ }^{46}$ As it directly challenged management rights and corporations' political power, this agenda was met with resistance from capital. Thus the early 1990s saw 'an increase in the number of strikes and lockouts ... in almost every instance, the disputes are caused

\footnotetext{
${ }^{43}$ March 1985 Council, President's report, 19.

${ }^{44}$ Bob White, Hard Bargains. My Life on the Line (Toronto: McClelland and Stewart. 1987), 96.

${ }^{45}$ November 1987 Council, President's report, 8.

46 August 1993 Council, President's report, 5.
} 
by employers demanding concessions. ${ }^{47}$ The $\mathrm{CAW}$ was able to protect its collective agreement, make advances, and, in some cases, protect jobs through striking. At this juncture the 'no concessions' policy was still active, and fighting back still allowed for a protection of the collective agreement. As will be detailed in chapter four, the mid 1990s saw the CAW make major strides in the area of bargaining for equity, with the union winning language to protect 'the right of a worker who is being harassed because of their sex, sexual harassment, racial harassment or religion, religious harassment, to refuse to work and be paid until the company found a solution to the problem that was acceptable to the worker. ${ }^{48}$ The CAW's victories in the area of equality bargaining seem to reflect Briskin's reasoning that during times of austerity and shrinking membership bases, unions should bargain for equality in order to support 'a revival of innovative collective bargaining, and, by extension, union renewal and revitalization. ${ }^{49}$

By the late 1990s plant closures had exacted a great toll on the CAW membership. With tens of thousands of jobs lost, the focus at the bargaining table shifted to a negotiation strategy with The Big Three to restore the auto sector. ${ }^{50}$ A healthy domestic auto sector meant protection for remaining $\mathrm{CAW}$ jobs. In some ways, this represented a major shift in CAW strategy: rather than using its collective economic strength to fight back against capital's advances, the union was now more willing to work with employers than ever before. Although the CAW was moving closer to working with its employers at the bargaining table, it was still using its relative economic strength to protect jobs. The first two years of the 2000s saw a strike wave within the CAW, most of which revolved around preventing outsourcing or plant closures. ${ }^{51}$ The late $1990 \mathrm{~s}$

\footnotetext{
${ }^{47}$ August 1993 Council, President's report, 15.

${ }^{48}$ President's report, 1996 Collective Bargaining and Political Action Convention, 35.

${ }^{49}$ Briskin, "Austerity, union policy and gender equality bargaining," 130.

${ }^{50}$ August 1999 Council, President's report.

${ }^{51}$ April 2001 Council, President's report.
} 
also saw the CAW win significant equity gains at the Big Three, negotiating 'a $\$ 10.00$ per day subsidy for young couples raising children five years of age or under, consistent with our national child care campaign.' 52

In 2001 the Council voted to re-affirm the no-concessions policy of the union, stemming from 'a couple of instances during the last 20 years where people have said: "to hell with the union policy, we're giving concessions." Both those plants closed within a couple of years of the workers giving up their wages. So you cannot buy job security. ${ }^{53}$ In addition to protecting the collective agreement, and preventing members from falling into the trap of attempting to buy job security, the union saw resisting concessions as key for the struggle for the totality of the labour movement - concessions could never take workers forward. To this end, at that same Council, the union moved to support 'any group of workers who are fighting concessions in our communities ... We have to come together as a union with the rest of the labour movement and send a message to the company that this struggle is a struggle of the total labour movement., 54

The CAW's approach to collective bargaining underwent a major change in the latter part of the decade, however. The capitalist world was in the midst of The Great Recession - the most severe economic downturn since the Great Depression. 2008 and 2009 marked the last of the CAW's ability to dramatically improve its collective agreements: 'when times are good, we've been able to bargain good collective agreements with increase in wages, benefits, pensions. We haven't had that luxury in a long, long time, since the financial crisis back in 2008-2009. ${ }^{55}$ At this point, the Big Three were suffering financially: Chrysler had been sold to a private equity

\footnotetext{
${ }^{52}$ December 1999 Council, President's report, 8.

53 December 2001 Council, President's report, 19.

${ }^{54}$ December 2001 Council minutes, 10.

${ }^{55}$ Chris Buckley, in discussion with the author, July 2013.
} 
firm, Ford had closed half its North American Plants, and GM had filed a loss of \$39 Billion. When the CAW entered negotiations with the Big Three in March of 2008, all three auto producers were experiencing sales decline. Under these conditions, the CAW agreed to minor concessions in the collective agreement: a cost-of-living increase was bargained in the first year, but the subsequent two years of the deal saw a wage freeze, and reduced vacation pay through concessions. The CAW accepted concessionary demands with the idea that material sacrifices would ensure short-term production of auto manufacturing in Canada, keeping members employed. ${ }^{56}$

As the recession deepened, the Big Three attempted to secure a loan from both the federal and Ontario governments to secure the future of auto production in Canada. In January 2009, GM demanded further concessions from the CAW and these concessions were supported by the Canadian government. Indeed, one of the requirements for the government loan was the extraction of $\$ 150$ Million in concessions from the CAW. Federal Industry minister Tony Clement made it very clear that public funds would not be used to 'maintain the standards of living for Canadian autoworkers' ${ }^{57}$ Under the joint pressure of capital and the state, the CAW eventually and signed a concessionary collective agreement on 9 March 2009. On the same day that CAW workers accepted the new agreement with GM, however, Chrysler rejected the agreement, claiming that it wanted to extract even more concessions from the CAW.

The CAW Council met in April of 2009 as the concessionary bargaining was ongoing. The union debated the concessions and endorsed a plan to 'fight back against the major

\footnotetext{
${ }^{56}$ Tim Fowler, "Does Fighting Back Still Matter?: The Canadian Autoworkers, Capitalist Crisis and Confrontation" Capital \& Class 36, no. 3 (October 2012): 487 - 507.

57 Ibid.
} 
concessions demanded of them by the employers and governments alike. ${ }^{58}$ Reaction to this recommendation on the floor was mixed. Chris Buckley, who had led a blockade against GM, recognized that concession bargaining was becoming the new norm, and more and more members were willing to grant concessions to secure short term production: 'there isn't a location that we have in Canada that hasn't gone to the employer and opened up their collective agreements, because we knew the market was shifting and we had to make changes, and our members agreed to make changes time after time. ${ }^{59}$ Other members completely rejected any form of concessions, noting that 'every auto producing nation around the world is giving loans and helping their industry. ... There's only two nations in the world that are attacking and demanding workers take concessions in order to get a loan, and that's the US and Canada. We really need to go on a full frontal attack as workers. ${ }^{60}$

The recommendation at the council passed, and the union initially took a hard line with Chrysler, refusing to make more concessions. As negotiations broke down, both the union and management took their fight to Chrysler employees and began negotiating in public. Chrysler threatened complete closure of Canadian operations if concessions were not accepted, pointing ominously to government threats to call for loan repayment if a deal had not been reached by 30 April 2009. On 21 April 2009, the Canadian government took the unprecedented step of intervening in private-sector bargaining and ordered Chrysler and the CAW to return to the bargaining table. Under the pressure of the state and capital, the CAW agreed to more concessions in order to secure short-term production. ${ }^{61}$

\footnotetext{
${ }^{58}$ April 2009 Council minutes, 39.

${ }^{59}$ Ibid.

${ }^{60} \mathrm{Ibid}, 42$.

${ }^{61}$ Fowler, "Does Fighting Back Still Matter?"
} 
Even after the concessions were granted and production was secured in the short term, there were still job losses in the Big Three. ${ }^{62}$ Indeed, the latter half of the 2000 s was full of stories of the CAW granting concessions - albeit never to wages - to secure short term production in manufacturing. ${ }^{63}$ Concessionary bargaining had become almost the norm. Tim Carrie, president of the Parts Council, noted it was sometimes impossible to give up concessions. ${ }^{64}$ Lewenza, CAW national President, agreed, noting the increased number of concessions the union has had to make: 'recent years, we have been much more flexible in our bargaining; much more pragmatic. We have had to make some - and I will call them sacrifices, some might call them concessions. ${ }^{65}$

In the last few years of the decade the CAW focused on deciding which areas would be protected from concessions. Protecting wages was paramount as 'once you give up wages it's almost impossible to get them back. ${ }^{66}$ As the no concession policy of the CAW was eroded, the union made the decision to not grant concessions in wages, benefits, or pensions - seeing these as the most important parts of the collective agreements. ${ }^{67}$ One area where the union was willing to grant concessions however was vacation and time off the job. Hargrove described time off the job as 'a cushion ... if companies really were in trouble, you had this cushion where you could give up, bargain additional time off the job when they were healthy, and then you could give up some of that when they were out of it. And so we did some of those things. ${ }^{68}$ By the end of the 2000s the CAW had suffered nearly two decades of plant closures as a result of free trade and

\footnotetext{
${ }^{62}$ December 2010 Council minutes, 9.

${ }^{63}$ Hargrove, Laying It On The Line, 227.

${ }^{64}$ Tim Carrie, in discussion with the author, July 2013.

${ }^{65}$ Lewenza, discussion.

${ }^{66}$ Hargrove, discussion.

${ }^{67}$ Buckley, discussion.

68 Ibid.
} 
neoliberal globalization. For most of this period, the union was able to mount various fight-back strategies, and while losing members to closed plants, protect its collective agreements. By 2010, the union had bargained major concessions to The Big Three collective agreements - the most important collective agreements to the union. While these were designed to ensure short term production and thus jobs for CAW members, this strategy proved to be limited as well: 'in 2012 bargaining we couldn't get one commitment out of GM beyond 2016.'69

\section{The Challenges of Free Trade}

From the CAW's first Council meeting, the union's concern about the state of the Canadian auto industry was clear. Imports were already eroding sections of the Canadian auto market, leading to job losses in CAW-organized workplaces. ${ }^{70}$ At the Council meeting, President White detailed his concerns about auto imports and their impact on the industry and council featured a lengthy debate on Japanese imports in Canada and the Canadian government's support of imports, detailing how imports posed a serious challenge to the CAW. ${ }^{71}$ When talk of free trade emerged between Canada and the US, White suggested that the CLC engage in a 'carefully thought out opposition from the Canadian labour movement.' 72 At this juncture, the CAW's position was not limited to defending its the automotive sector but rather it raised many issues of concern to the broader working class - job losses, attacks on social security, attacks on collective bargaining. ${ }^{73}$ By December 1985 , free trade had become the dominant political issue facing the CAW, with Gindin delivering a special report on free trade that was endorsed by many

\footnotetext{
${ }^{69}$ Buckley, discussion.

${ }^{70}$ December 1985 Council, President's report, 12 - 13.

${ }^{71}$ March 1985 Council minutes.

72 June 1985 Council, President's report, 7.

73 Ibid.
} 
members. ${ }^{74}$ Free trade was thus not only a major issue for the leadership, but was one around which the members of the union could coalesce.

Free trade remained the union's central issue the following year when it constituted the centrepiece of the president's report at Council. The political education department also focused most of its energy on fighting free trade. ${ }^{75}$ The CLC had also started a campaign against free trade, and the CAW was engaged with other unions in the airline and transportation sector in a multi-union campaign against deregulation and free trade, endorsed by Council delegates. ${ }^{76}$ One of the union's first actions was a candlelight vigil at Queen's Park to protest the inclusion of the Auto Pact in free trade negotiations. ${ }^{77}$

The 1988 federal election, dealt with in greater detail in chapter five, was fought almost exclusively over the issue of the proposed free trade agreement. The CAW took on a leadership role in the anti-free trade movement. For example, White played an active role in convincing the CLC executive to develop a national message against free trade. ${ }^{78}$ In the lead-up to the 1988 election, the union sent a document, "Free Trade Could Cost Us Canada," to every single member, detailing the proposed agreement's potential impact. ${ }^{79}$ The union worked with various social movement allies, the CLC, the Federations of Labour, the Pro-Canada Network, the Coalition Against Free Trade, and the NDP to oppose the agreement. ${ }^{80}$ White acknowledged that he 'was spending as much time fighting free trade as I was fighting the corporations. I seem to

\footnotetext{
${ }^{74}$ December 1985 Council minutes.

${ }^{75}$ March 1986 Council, President's report; March1986 Council, national and area staff reps report.

${ }^{76}$ September 1986 Council, President's report 8; September 1986 Council minutes.

77 June 1987 Council, national and area staff reps report, 1.

${ }^{78}$ White, Hard Bargains, 358.

${ }^{79}$ Ibid, 360.

${ }^{80}$ December 1987 Council, President's report.
} 
have been one of the first to react to Prime Minister Mulroney’s initiative.' 81

The CAW lost the first, and one of the most consuming, political battles the new union had engaged in. Despite fierce opposition, the Progressive Conservatives won the 1988 election and signed the agreement with the United States. ${ }^{82}$ In reaction to the signing of the agreement, $400 \mathrm{CAW}$ members shut down the peace bridge. ${ }^{83}$ While the union continued to fight future free trade proposals, the impact of this loss was profound. The union had mobilized members, built alliances, but nonetheless lost. In future struggles, rank and file members would come to be less and less engaged in what they saw as a losing battle ${ }^{84}$ but Gindin suggests that the leadership was also too tired of the fight. Thus future calls to fight free trade were made simply because they were expected: 'every Council report says something about the latest thing, and you get to speechify, because if you didn't put it in your speech, you'd be criticized for it. But you don't intend to do anything. ${ }^{85}$

White recognized that the signing of the free trade agreement represented a fundamental change in Canadian politics, noting

'whether we like it or not, the world has changed. ... Free trade also is only one part of a much larger agenda, an agenda that allows much more deregulation and privatization; an agenda that allows much more corporate concentration of power, much more foreign investment, and yes, an agenda that will ultimately try and attack social programs and make it difficult to improve and expand our current social services. ${ }^{, 86}$

${ }^{81}$ White, Hard Bargains, 357.

${ }^{82}$ The Free Trade Agreement of the Americas was negotiated between the federal governments of Canada and the United States, and it was signed by the Canadian federal government. The agreement was, however, binding on all the provinces, even though they were not direct parties to negotiations. The Canadian provinces have constitutional jurisdiction over labour law, so much neoliberal restructuring of labour and employment law occurred at the provincial level in the wake of the FTA.

${ }^{83}$ March 1988 Council, national and area staff reps report, 2.

${ }^{84}$ Sam Gindin, in discussion with the author, July 2013.

${ }^{85}$ Ibid.

${ }^{86}$ February 1989 Council, President's report, 14 - 15. 
Without explicitly naming it as such, the CAW had recognized that the agreement reflected the embedding of a neoliberal agenda in Canada. Economic globalization is an important policy facet of neoliberalism and the adoption of the FTA by the Canadian government solidified the growing neoliberal policy agenda in the country. Its adoption meant increased external pressure on the domestic automotive industry and, as noted above, as jobs began to leave Canada, the CAW experienced a sudden and sharp decline in their membership base. The neoliberal agenda was understood as a threat to jobs, its members, and to many of the larger social projects the union supported. Because of this, the union committed to a 'fight back campaign' where it would 'play a leadership role ... to continue our work with the various groups in the coalitions formed around free trade. ${ }^{87}$ The union leadership however saw electoral politics as the main arena for the struggle against free trade.

By 1990 the Canadian and American governments were seeking to include Mexico in continental free trade arrangements. Very early in the 1990s the union began mobilizing its members against NAFTA. White highlighted the dangers of NAFTA posed to the auto industry, suggesting that the agreement would bring about even more plant closures. ${ }^{88}$ Hargrove's first presidential address to the CAW stressed the need to fight NAFTA as a key political goal. ${ }^{89}$ In 1992, the unions prepared a campaign against NAFTA, centred around the demand for an 'election prior to ratification by parliament. ${ }^{90}$ In the 1993 federal election campaign, the union highlighted the defeat of NAFTA as its key electoral priority. ${ }^{91}$ When the Liberals won the 1993 election and went on to sign NAFTA, the union saw this as a major defeat. Addressing Council,

\footnotetext{
${ }^{87}$ Ibid, 16.

${ }^{88}$ December 1990 Council, President's report.

${ }^{89}$ June 1992 Special Council, Buzz Hargrove's address, 22.

${ }^{90}$ August 1992 Council minutes, 43.

${ }^{91}$ August 1993 Council, President's report, 23.
} 
Hargrove called on the union to expand its struggles into a more class-based opposition to neoliberal policies: 'Whether we accept it or not, NAFTA is a reality. We must challenge ourselves to come up with new ideas, if we are to ever seriously challenge the increasing power of capital. I am confident that we can find ways of dealing with this challenge, but only if we get membership and public support. ${ }^{92}$

The struggle against free trade however dropped off the CAW's political agenda until 1998, when Hargrove called for a massive campaign to save the auto industry. ${ }^{93}$ In 2000 the union was dealt a major blow when the WTO ruled against the Auto Pact. This created the potential for massive divestment of the Canadian auto industry and subsequent job losses for CAW members as 'the Big Three are no longer required to invest in jobs in Canada commensurate with their market share in Canada. ${ }^{94}$

In late 2003, the union called for a wide-ranging Canadian automotive strategy. ${ }^{95}$ 'With the amount of publicity we receive, it [the automotive sector] sets a standard for unions throughout North America as well. ${ }^{96}$ Interestingly, the recommendation met with some criticism from the Council delegates. One delegate criticized the union for calling for an auto strategy as it blurred class lines: 'to call it a strategy or a policy is to dress it up. What it amounts to is a large reams of public assistance paid for private corporations for the failed notion that somehow that will entreat corporations to stick around. Because of the mobility of capital and the kind of assault the corporate agenda takes today, we need better than that. ${ }^{97}$

The Council proved to be a very important forum for debate on this question. Different

\footnotetext{
${ }^{92}$ April 1994 Council, President's report, 17.

${ }^{93}$ April 1998 Council, President's report.

${ }^{94}$ Ibid, 16.

${ }^{95}$ April 2003 Council minutes.

${ }^{96}$ December 2003 Council, President's report, 12.
} 
strategies were debated, but, in the end, support for the automotive strategy - the position of CAW leadership - became the union's position. A critical, class based assessment of the automotive strategy found little resonance among the delegates who generally favoured support for auto producers as the only way to secure employment. Some delegates expressed sympathy but refused to support it on a pragmatic level:

'I applaud Willy when he gets up and he talks about where we should philosophically go. But I can't worry about the philosophical end-run game, I can't worry about where we have to go in the big game, but we have a responsibility to our members. This is a concrete solution and I applaud the leadership and recommend that everyone wholly supports it.' 98

Indeed, the overwhelming majority of comments from the floor suggested a very low level of class analysis when it came to automotive strategies: 'As a good socialist I should be against the recommendation. Nevertheless, I'm going to leave aside my principles of socialism and I'm going to support this recommendation.' 99 Most of the speakers criticized the government for not intervening to keep jobs in Canada. ${ }^{100}$

Free trade remained an issue however that would continue to come up at CAW Council. In 2005, there was a recommendation that the Council, 'reaffirm our determination to scrap the FTAA and NAFTA. ${ }^{101}$ In this instance, free trade was presented as an issue of concern to CAW members and the broader Canadian working class. For CAW members, free trade was making it increasingly difficult to bargaining collectively - as automotive capital could move jurisdictions much easier. ${ }^{102}$ For the broader Canadian working class, free trade entailed an attack on public

\footnotetext{
${ }^{97}$ April 2003 Council minutes, 32.

98 Ibid, 38.

${ }^{99}$ Ibid, 41.

${ }^{100}$ Ibid.

101 April 2005 Council minutes, 43.

102 Ibid.
} 
pensions, health care, infrastructure, energy, water, and other 'basic standards of living.' 103 It was at this point however that an inconsistency between the CAW's political issues and its electoral strategy became apparent. As we shall see in chapter five, although the Liberal government was in the midst of expanding free trade and ministers would not meet with union officials, the union continued to support the Liberals - a party in favour of free trade.

The CAW saw a proposed free trade agreement between Canada and Korea as a threat to many of the sectors of the economy: 'auto sectors, ship building, tool and die industry, electronics.' ${ }^{104}$ The union leadership encouraged CAW locals to 'solicit letters from their employers opposing the Canada-Korea FTA.' ${ }^{105}$ A year later, another recommendation was introduced called on CAW members to participate in a letter writing campaign to oppose free trade with Korea. ${ }^{106}$

In 2008 the CAW rolled out a Manufacturing Matters campaign designed to highlight the importance of manufacturing to the Canadian economy and to CAW members. ${ }^{107}$ The campaign was directly linked to the waves of plant closures that the CAW had experiences as a result of free trade. The campaign, however, was not centred on unionized jobs, nor, indeed, the promise to unionize non-union manufacturing workplaces. It was simply a campaign to put manufacturing on the political agenda of Canadian politics. The campaign was also closely linked to the CAW's "Made In Canada Matters" campaign, which urged CAW members, and the general public, to purchase vehicles made in Canada. This campaign lacked a class, or even union, based analysis. Suggesting that Made In Canada was the most important feature of

103 Ibid, 44.

${ }^{104}$ December 2005 Council minutes, 37.

105 Ibid, 35.

106 April 2006 Council minutes.

${ }^{107}$ March 2008 Council, President's report, 10. 
manufactured vehicles ignores the fact that many vehicles made in Canada are not union made, as well as the fact that there are union made vehicles from the United States sold in Canada.

While the auto manufacturers were

'turning the corner to prosperity when the global financial crisis [of the late 2000s] hit. People could not get loans for cars. Car sales in the US are at their lowest point in 50 years. ... That is 5 million fewer vehicles that we are building in Canada to support the sales. That is 5 million fewer vehicles that we are providing components and parts for.' 108

The Great Recession was also occurring as the Canadian government was opening up new free trade agreements with Columbia, Korea, and the EU - all of which had the potential to undermine Canadian production and cost CAW members jobs. ${ }^{109}$

The union leadership often presented the struggle against free trade in class terms: according to the last national President, Ken Lewenza, free trade should be seen as a project of global capital. ${ }^{110}$ The leadership always urged Council delegates to challenge free trade, and encouraged activities like letter writing campaigns and an electoral strategy designed to fight free trade at the ballot box. None of these strategies were successful. While the union continued to campaign against free trade whenever a new agreement was proposed, 'now the problem is, you end up sounding like a broken record, you know, you're fighting a free trade agreement everywhere.' 111

Fighting Back-Responses to Plant Closures

The union developed a variety of responses to plant closures over time. As noted, the CAW attempted to secure the future of plants at the bargaining table but a great deal of the

\footnotetext{
108 December 2008 Council, President's report, 9. First report of Ken Lewenza.

109 December 2009 Council minutes, 11.

${ }^{110}$ Lewenza, discussion.

111 Stanford, discussion.
} 
'fighting back' against plant closures involved supporting the NDP, as parliamentary politics were seen as the main avenue for resisting plant closures, a point to which we will return in chapter five. Its tactics however also came to include 'contentious politics' - ie, occupations, pickets, demonstrations, etc.

When the Council first debated plant closures, various ways that the union could fight back, including demonstrations, letters to MPs, and public awareness campaigns, were discussed. The discussion did not however include plant occupations, strike action, or even tougher collective bargaining. ${ }^{112}$ One brother suggested the best course of action on plant closures would be to 'send letters and telegrams to the Premier, the Minister of Labour, demanding advanced notice and justification, and severance pay.' ${ }^{113}$ Another actively opposed any direct action with regards to plant closures: 'We can't take the plants over because now if we take the plants over the companies go after us and they will turn around and they will sue us for our severance pay. ${ }^{114}$ CAW staff members called for members to vote NDP in upcoming elections as a solution to plant closures. $^{115}$

These voices from the Council floor showed a reluctance to engage in workplace action and instead to rely on social democratic parties and parliamentary based politics. White's analysis was sharper: "we have to remember and recall and understand that what is taking place here is not taking place by accident, what is going on in our country today is a planned restructuring of our economy and don't defend the corporation because it is a corporate agenda that the big business political parties are following. ${ }^{116}$ That said, even White did not propose a

${ }^{112}$ Ibid.

${ }^{113}$ August 1990 Council minutes.

${ }^{114}$ Ibid.

${ }^{115}$ Ibid.

${ }^{116}$ Ibid. 
more militant course of action. Later on that year, the issue of plant closures once again was debated. At this juncture, one member did suggest a "national day of protest, a day of work stoppage' over plant closures ${ }^{117}$ but this plan was not endorsed by the union.

At a Council debate in 1996, plans for fighting back against plant closure focused on 'demanding the Canadian government have the political courage to stand up for Canadian jobs.' 118 As Hargrove would later reflect, 'the Mike Harris / Stephen Harper crowd, who swear that raw capitalism can solve every problem, defend the freedom of capital to move anywhere at any time.' 119 A year later when the issue of plant closure again arose, however the discussion focussed on listing the plants that had closed. There was no discussion of strikes, occupying plants, collective bargaining, or even appealing to government. The CAW had come to see the issue of plant closure as a problem that could be solved through electoral politics. The union's reliance on an electoral strategy to combat plant closure laid the groundwork for the shift in electoral strategy to one of strategic voting, which will be elaborated on in Chapter five.

The mid 1990s also saw the union push back strongly against plant closures. At the bargaining table, the union bargained with both The Big Three and the auto parts sector to protect against outside contractors doing CAW work and to prevent further outsourcing of work from plants. In fact outsourcing was made the number one bargaining priority in $1996 .{ }^{120}$ The union made major gains in this area, winning language with Chrysler that protected against outsourcing, restricting the corporation's right to sell a plant or to close a plant during the life of the collective agreement, as well as bargaining a wage increase above inflation. ${ }^{121}$ The $1990 \mathrm{~s}$

${ }^{117}$ December 1990 Council minutes, 75.

118 Ibid, 16.

${ }^{119}$ Hargrove, Laying it on the Line 193.

${ }^{120}$ April 1996 Council, President's report, 12.

${ }^{121}$ December 1996 Council, President's report, 11. 
saw a swell of direct action in opposition to plant closures. In 1998, when GM decided to close a plant and move to another parts supplier, under the guidance of Mike Shields, Local 222, led a wildcat strike against GM which resulted in a commitment from GM to leave the work at the plant, and not close it. ${ }^{122}$ In 1997 CAW members engaged in collective bargaining at PC World, which eventually resulted in an eight month long strike, bargaining in bad faith charges upheld by the OLRB. When PC World resorted to using scab workers, CAW members occupied the PC World plant in order to halt all production. At 4 am on September $8^{\text {th }} \mathrm{CAW}$ members took the plant, shutting down production until September $11^{\text {th }}$. This tactic proved to be very successful, putting enough pressure on the $\mathrm{CEO}$ of $\mathrm{PC}$ World to negotiate a new collective agreement by September $13^{\text {th }} .{ }^{123}$

While the union was still facing plant closures in many sectors of the economy at during the 1990s, it was clearly evident that the union still had significant economic strength to protect the members' jobs, and livelihoods through collective bargaining. When bargaining failed, the union was more than willing to use other tactics however. CAW members successfully struck against GM to stop outsourcing, and, at another strike against GM, CAW members occupied a plant to prevent GM from moving fabrication dies out in a bid to outsource CAW work. ${ }^{124}$

While the CAW was seemingly retreating through the 1990s, and relying on less and less contentious methods of fighting back, some pockets of radical militancy remained. When a Venatratech plant in Cambridge announced it was closing and would not negotiate a close-out agreement, the CAW local occupied the plant until the employer agreed to bargain a closing

${ }^{122}$ April 1998 Council minutes, 13.

${ }^{123}$ December 1997 Council, President's report, 13.

${ }^{124}$ December 1996 Council, President's report. 
agreement. $^{125}$ The remainder of the 1990s saw more plant closures and layoffs in all sectors of the union, resulting in more than 10000 jobs lost. ${ }^{126}$

The issues of concessions and union militancy played out at GM Canada headquarters in 2008. During the 2006 round of collective bargaining, GM announced they would be closing Car Plant Two in Oshawa in 2008, and if the union did not accept concessions in order to 'attract new investment,' they would close Car Plant One in 2009. ${ }^{127}$ In May of 2008, GM and the CAW reached an agreement in which CAW members took concessions to their collective agreement, and, in exchange, GM agreed to postpone the closure of Car Plant One. Three weeks after the new collective agreement was signed, GM announced that they would be closing Car Plant One anyway. Hargrove quickly relayed this information to local president Chris Buckley, who began to organize a fight-back. ${ }^{128}$

Buckley was hesitant to strike the plants. The rising price of oil and declining vehicle sales meant that a strike would make it even easier for GM to close the plant right away. Instead of striking the plant, Buckley decided 'to take their headquarters away.' ${ }^{129}$ On 04 June 2008 the CAW began a blockade of GM Headquarters in Oshawa, preventing GM office staff and executives from accessing their headquarters, while at the same time keeping production going in the physical plants. Twelve days into the blockade, the courts ruled it illegal. CAW members ended the blockade. Although the union was unable to save the plant, they were 'were successful in bargaining the most lucrative plant closure agreement in our history that took care of over 3,000 of our most senior members and their families, to save the jobs of 3,000 union

${ }^{125}$ April 2005 Council minutes, 17.

${ }^{126}$ December 1998 Council, President's report; August 1999 Council minutes; December 1999 Council, President's report; April 2000 Council, President's report.

127 April 2006 Council, President's report, 2.

${ }^{128}$ Buckley, discussion. 
members. ${ }^{130}$ Further disruptions of GM headquarters or stopping production were ruled out, due to the fragile nature of the North American auto market - the union did not want to risk losing more jobs.

This case shows that even in severe economic downturn the union was able to slow plant closures through a militant fight-back strategy. However, slowing the plant closures was all the union was able to do. The power of capital to seamlessly move globally prevented the union from stopping the plant closure altogether.

In the late 2000s, the CAW also turned its attention to municipal politics in the interest of supporting domestic manufacturing and opposing free trade. The initial impetus came from activists within the union, who would lobby municipal leaders on issues of importance to the union. $^{131}$ This grew into a CAW wide campaign mentioned above, Made In Canada Matters. The latter involved lobbied municipal governments across Canada to ensure that municipalities procured domestically made products, including municipal vehicles, wherever possible. ${ }^{132}$ Malcolm Allen, a CAW activist who would later go on to become the NDP MP for the Welland riding, started his political career as a member of city council in Fonthill. Among other things, he was able to convince the city council and mayor to move away from public-privatepartnership models of service delivery, and to highlight the importance of domestic procurement, two issues of political importance to the CAW. ${ }^{133}$

The most major "fight back" against job losses in the latter half of the 2000s was a "job cemetery.' The union erected this cemetery on Parliament Hill, raising a tombstone for each

\footnotetext{
129 Ibid.

${ }^{130}$ Ibid.

131 Jenny Ahn, in discussion with the author, June 2013.

132 Ibid.

${ }^{133}$ Malcolm Allen, in discussion with the author, June 2013.
} 
workplace that had closed or had experienced major job losses - over 500 tombstones in all. The Prime Minister's Office ordered the RCMP to remove the graveyard, but CAW 'members flooded the area and the RCMP were convinced to leave our display alone.' ${ }^{134}$ This action preventing the police from removing a demonstration on Parliament Hill - was considered to be the biggest victory against plant closures in the last half of the 2000s.

\section{Organizing and Mergers}

Free trade resulted in an increasing number of plant closures, and as detailed above, plant closures led to a significant downturn in CAW membership. When the Canadian UAW split from the international union to form the $\mathrm{CAW}$, the membership was predominantly male, white, and employed in the automotive sector or the automotive parts sector. As the union expanded for the next two and a half decades, there were substantial shifts to the makeup of the membership. As Heather Jon Maroney noted, in the era of neoliberalism and hollowed out manufacturing, 'large industrial unions have turned to women. With recession-induced instability and shrinking employment in the manufacturing sector, unions, forced to find new ways to secure a membership base, have supported organizing drives in small plants or moved to sign up clerical and service workers. ${ }^{135}$ When the CAW was a new Canadian union the President's report would note that ' 1 in 8 CAW members is a woman, $90 \%$ of CAW members live in Ontario, Windsor Toronto, and Oshawa accounted for half the membership. 50\% worked in the auto sector, $20 \%$ in the parts sector. ${ }^{136}$ A short three years later, the demographic characteristics of the union were changing rapidly: $20 \%$ of CAW membership was female,

\footnotetext{
${ }^{134}$ December 2007 Council, national and area staff reps report, 51.

${ }^{135}$ Heather Jon Maroney, "Feminism At Work," in Feminism and Political Economy: Women's Work, Women's Struggles, eds. Heather Jon Maroney \& Meg Luxton, eds. (Toronto: Methuen Publications. 1987), 89.

${ }^{136}$ President's report to the 1987 National Collective Bargaining and Political Action Conventions.
} 
largely as a result of organizing in new sectors of the economy. ${ }^{137}$ A decline in CAW membership, especially in the automotive sector, proved to be a major threat to the future of the union as automotive and manufacturing members represented a significant financial base. As these members declined, the union saw a shrinking dues based, which would significantly restrict its ability to engage in political action. Thus, in addition to actively lobbying for the future of automotive manufacturing in Canada, the union began to become increasingly aggressive in organizing new workplaces. Organizing these new members, as chapter four outlines, created a collective action dilemma akin to what Offe and Wisenthal described - the size of the union expanded, causing the union to have to incorporate more and more different identities into the culture and overall identity of the union. These new members led to 'the numerical feminization of the centres of male working class power and of the labour movement as a whole.' ${ }^{138}$ As chapter four will show, the numerical feminization did not equate to feminist power or ideological feminization of the labour movement.

Organizing new workplaces was a necessity to the survival of the CAW. For the CAW, organizing the working class meant that more Canadian workers would have access to collective bargaining and would be politicized, hopefully, through trade union action. The CAW also greatly expanded its membership through mergers with other unions, which was one of the easiest ways to expand the membership base: 'over the long term, the auto industry was going to start going the other way and we would be a much weaker organization if we simply relied on our auto base. So the mergers were the easiest and quickest way to do that.' ${ }^{139}$

Table 3 -5 shows the number of new CAW members organized on a yearly basis,

\footnotetext{
${ }^{137}$ February 1990 Council, national and area staff reps report, 25.

138 Maroney, "Feminism At Work," 89. Emphasis mine.
} 
excluding members from mergers. ${ }^{140}$ As the data shows, there is no clear pattern to organizing, however, the following paragraphs will attempt to link some of the peaks and valleys with key events both internal and external to the union. When the Canadian UAW broke away and formed the CAW, it had '70 000 members in the auto industry, 30000 in the auto parts industry, 10000 in the communications and electronics, and the rest, more than 30000 , scattered through the agricultural implement sector, the airlines, salt processing, pet food, candy bars, pharmaceuticals, and whisky. ${ }^{141}$ As noted above, mergers with other unions became the primary method for expanding the union's membership base. However, the CAW took a more proactive role in organizing new members than the UAW ever did, and within the first two years, the CAW had organized 90 new units, representing 6700 new members, into the union. ${ }^{142}$

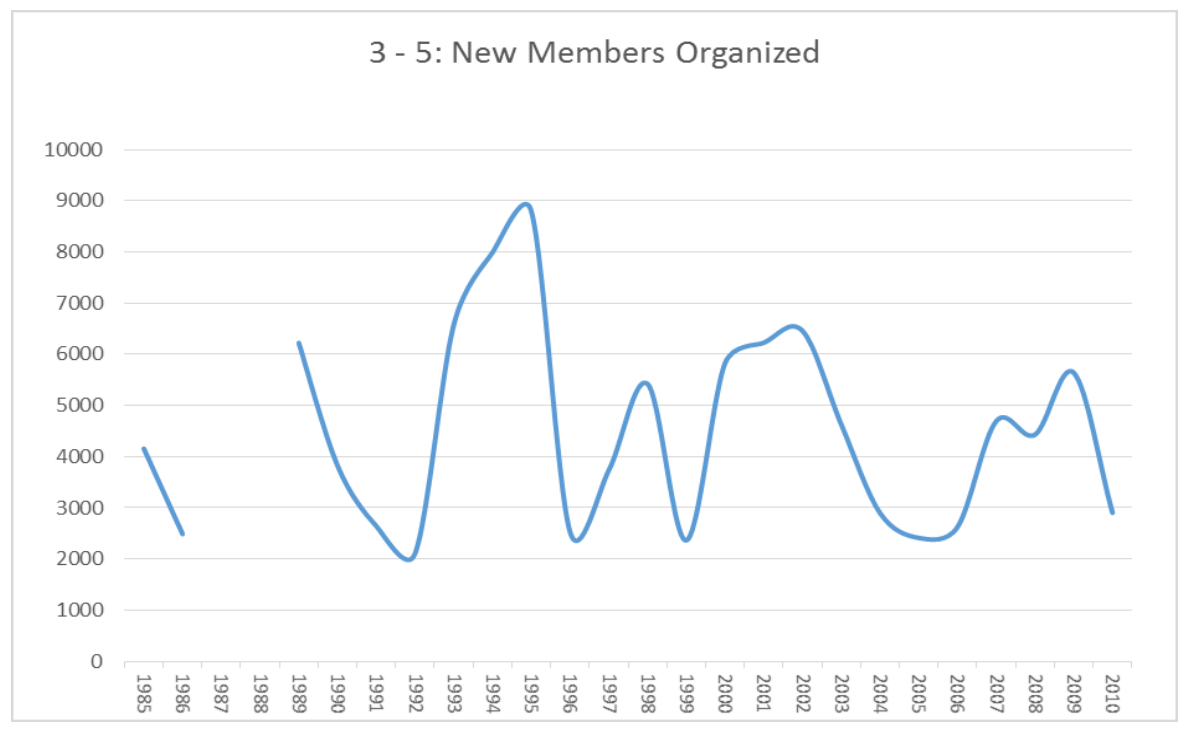

Within months of forming the CAW, the union undertook its first merger, joining with the Canadian Air Line Employee's Association (CALEA), which brought 4500 new members

${ }^{139}$ Hargrove, discussion.

${ }^{140}$ Source: national and area staff reps reports submitted to council. No data was provided in 1987 and 1988.

${ }^{141}$ White, Hard Bargains, 14.

${ }^{142}$ President's report to the 1987 National Collective Bargaining and Political Action convention, 2. 
into the union. ${ }^{143}$ This merger was significant not only because it represented the CAW's first merger, but also because it significantly changed the union's composition. The majority of CALEA members were women whereas until this point the base of the CAW had been overwhelmingly male. Both organizing and mergers - but especially mergers - changed the membership base of the CAW over time from a predominantly white and male one to one with a much more diverse membership base. Further, organizing new members and mergers also contributed to a more sectorally diverse union, and thus the leadership had to grapple with providing meaningful representation for workers from diverse sectors, especially those outside the CAW's traditional base in auto.

The first major commitment to organizing new members came in 1986, when White called on the union to dedicate a 'significant amount of money and supplement our organizing staff with a special organizing team for a period of three years.' ${ }^{144}$ Ten new organizers were hired from within the rank-and-file. One of the results of this was a major increase in members in 1989, well above what the union was organizing without this new commitment. The late 1980s also saw major mergers, including one controversial one. The United Fishers, in 1987, voted to leave the UFCW and join the CAW. Other unions within the Canadian labour movement, including the UFCW, claimed that the CAW was raiding members, while the CAW responded by saying that they were much more democratic than the UFCW, and if the fishers wished to leave the CAW and rejoin the UFCW, they were free to do so. ${ }^{145}$ This sparked a yearlong battle within the CLC, and strained relations between the CAW and other private sector unions - especially the UFCW. In 1989 the fisheries workers in the CAW saw an increase, when

\footnotetext{
${ }^{143}$ June 1985 Council, President's report, 15.

${ }^{144}$ September 1986 Council, President's report, 15.
} 
the Great Lakes Fisherman and Allied Workers Union merged into the CAW. ${ }^{146}$

When White left the CAW for the CLC he highlighted, among other things, the record the union had for organizing, and stressed that the CAW needed to continue to organize: 'A lot of that organizing has off-set some of the losses that we have had and we have seen many of our members lose their jobs as a result of plant closures and as a result of layoffs. ${ }^{147}$

While the 1990s started with a potential merger with the Brotherhood of Railway Carmen of Canada, the focus on the organizing department quickly became the service sector. ${ }^{148}$ In 1994 the CAW council voted to give more money to the organizing department and to intensify organizing efforts; this paid off with 7900 new members organized in 1994 and 8800 new members in 1995 - major increases over numbers in previous years. The union explored new tactics to help with organizing, using radio and TV ads to assist in the organizing drive - these tactics proved so successful, they became part of the CAW's overall organizing strategy. ${ }^{149}$ The organizing department also shifted focus to 'a method of organizing that is grassroots and community based,' which would also be a cornerstone of the union's organizing strategy. ${ }^{150}$ 1995 was another banner year for the organizing department, and it also saw 1200 new members through a merger with the Canadian Association of Communications and Allied Workers. ${ }^{151}$ 1995 also saw the election of Progressive Conservative Mike Harris in Ontario - the province with the most CAW members. The Harris government dramatically changed the rules governing organizing in the province, making it much harder. These changes had a profound

\footnotetext{
145 June 1987 Council, President's report.

146 June 1989 Council, President's report, 7.

${ }^{147}$ Special One Day Council, 1991, Bob White's report, 5.

148 August 1990 Council, President's report, 19; August 1990 Council, national and area staff reps report.

149 December 1994 Council, President's report, 22.

${ }^{150}$ December 1992 Council, national and area reps report, 24.

${ }^{151}$ April 1995 Council, President's report, 36.
} 
effect on the union, which saw a precipitous drop from 8800 new members organized in 1995 to 2500 in 1996 and 3700 in 1997 . Indeed, the union would not see major success in organizing until the early 2000s. The restrictions on organizing, at a time when the union was aggressively organizing new members, helps explain the CAW's overwhelming desire to drive the Progressive Conservatives out of office in Ontario, as detailed in chapter five.

By this time, more members were being brought into the CAW via mergers than through organizing, and the union was growing increasingly heterogeneous. These members came from a wide range of sectors, including an ever-growing number of workers from the service sector. The union saw 'diversifying membership by moving into the service sector was a way of keeping in step with changes in the economy. ${ }^{, 152}$ Mergers continued on through the 2000 s, with a major merger with the FSSA in Quebec bringing in 4500 new members. ${ }^{153}$ By 2008, the CAW had gone through 33 mergers, bringing in over 100000 new members. ${ }^{154}$ The CAW completed mergers with the Retail Wholesale Canada union in 2001 and the McMaster University Staff Association in 2005, representing completely new areas of representation for the union. ${ }^{155}$ In 2007 the Council voted to have all locals 'recommit their efforts to play a more significant role in building the union through our organizing efforts,' and nationally, the union added ten new organizers to the organizing department. ${ }^{156}$ These moves saw a slight uptick in organizing in the CAW, with over 5000 members being organized in 2009 - the first time that had happened since 2002 .

2007 also saw one of the most controversial organizing decisions the CAW has ever

${ }^{152}$ Hargrove, Labour of Love, 113.

${ }^{153}$ December 2003 Council, President's report, 9.

${ }^{154}$ Hargrove, Laying it on the Line.

${ }^{155}$ December 2001 Council, President's report; December 2005 President's report.

${ }^{156}$ April 2007 Council minutes, 18; December 2007 Council, President's report, 11. 
made. The union entered into an agreement with Magna International, titled The Framework for Fairness in an effort to organize the parts workers at Magna. Magna had been an organizing goal for the union for decades, and the owner, Frank Stronach, was exceptionally anti-union. The Framework called for Magna to grant card-check neutrality to the CAW. If organized, the new CAW members at Magna would not have the right to strike: outstanding issues from collective bargaining would be sent to interest arbitration. Further, these workers would not have a traditional steward structure at the workplace; workers would instead be represented by 'employee advocates,' who were subject to approval by the employer. While the Framework was supported by the CAW leadership, and eventually passed, it was heavily criticized by those on the left in the union, and, indeed, nationally by left leaning trade unionists across Canada. To them, the Framework was seen as the thin edge of the wedge of admitting defeat to the neoliberal agenda: it represented organizing new members at any cost, even if they would not have access to what were considered the basic principles of trade unions - stewards and striking.

The CAW had, with no success, been trying to organize Magna for over thirty years. ${ }^{157}$ The Framework was initially proposed by Magna CEO Stronach: 'Stronach said, "why are we wasting all this time and effort fighting one another? If you guys agree to some things, we're willing to open up the plants and let your organisers go in without any interference from management." ${ }^{158}$ Hargrove agreed with the position of Stronach, noting that deindustrialization had resulted in the CAW's presence in the parts sector being reduced from $30 \%$ of workers unionized in the $\mathrm{CAW}$ to around $7 \% .{ }^{159}$ For Hargrove, there was a concern that continual divesment would mean that 'non-union companies setting the standard for the unionized plant'

\footnotetext{
${ }^{157}$ December 2007 Council, President's report, 18.

${ }^{158}$ December 2007 Council, President's report, 19.
} 
and both Hargrove and Stronach were concerned with the continual decline of manufacturing in North America. ${ }^{160}$

The proposal generated immediate controversy both within and outside of the union, centred around the proposal for binding arbitration. The leadership supported The Framework, and responded to the proposal for binding arbitration by suggesting that they were not "giving up" the right to strike: "the difference with us is that we are not giving up the right to strike for Magna workers, because they don't have it now. They never had it. They don't even have a union.' ${ }^{161}$ Many on the left saw this defence as exceptionally weak - one of the main raison d'etres for organizing a trade union is the ability to collectively assert economic strength through striking. To form a union and to give up this right was seen as counter-intuitive at best, and, at worst, an implicit surrender of the labour movement to capital.

The Framework was defended by the union leadership at Council. Jim Stanford described it as a first step: 'get some entry, and then go in to build the union bit by bit over the next years and the next decades.' 162 Stanford also described the Framework as key in the strategy to 'preserve the union density, our unionization in the Canadian workforce as a whole,' and did recognize that 'The problem with voluntary recognition is you have to cut an agreement. You have to win some kind of an agreement with the employer in order to get it. ${ }^{, 163}$ In many ways, the Framework represented a strategy of "union density no matter the costs," and it seemed, here, as if the leadership was implicitly saying this as well.

At the Council Tim Carrie fully supported the Magna agreement: 'this helps dispel the

${ }^{159}$ Hargrove, discussion.

${ }^{160}$ Ibid.

${ }^{161}$ December 2007 Council, President's report, 19.

162 December 2007 Council minutes, 8.

${ }^{163}$ Ibid $8-12$. 
myth that unions cause difficulty. This is a very sophisticated management that realises unions can stabilize workplaces and can work with management to improve workplaces. ${ }^{\text {164 }}$ Carrie's statements are correct - unions can stabilize workplaces, however, in this case, the Framework represented a clear shift rightward towards business unionism. The business unionism inherent in the Framework was highlighted by another brother who was in favour, suggesting that the biggest victory in the Framework would come in getting an ally who could help protect the auto industry in Frank Stronach: 'but the truth is he does share our opinion, at least on this agenda, that we have to have government intervention if we're going to protect this industry, and if we can't get a meeting, our leader can't get a meeting with Stephen Harper, I think that perhaps Frank Stronach might have a better opportunity.' 165 Similarly, another brother argued that the Framework was important because lots of CAW members gives the CAW 'clout ... we have in the country is because we do have good union density in our key sectors. We do have clout, and people have no other choice but to listen to us. ${ }^{, 166}$

There was a good deal of opposition to the Framework at Council. Chris Buckley, the President of local 222 and an NEB member, opposed the recommendation to support the

\section{Framework:}

'I'm not against Magna workers joining the greatest union in the country. .. When they do join our union, it's my belief that they should have the same rights as all of us have as long as we've been members of this great union, specifically that being the right to strike. ... It does worry me that as we move forward and go down this path, other employers will be demanding the same type of agreement.' 167

Buckley's analysis was closely in line with the 'no concession' policy of the CAW, that once

\footnotetext{
164 Ibid, 25.

165 Ibid, 47.

166 Ibid, 53.
} 
you grant concession in one area, all employers will begin calling for concessions, anticipating that any other employer in the parts sector (and beyond) would be given a reason to demand a no-strike agreement. Another brother, who had been through 'six sets of negotiations for three different unions,' opposed the Framework because 'without the right to strike, I'd be putting sand through a sieve. I'd have no power. ${ }^{168}$ Another voice in opposition was deeply concerned that the Framework would undermine the CAW's position as a leader in the Canadian labour movement: 'when you have the largest private sector union in Canada pairing up with the largest parts supplier in Canada, no one can tell me today that this is not going to somehow have some kind of effect across the broader labour movement., ${ }^{169}$

The opposition to the Framework highlighted the problems of giving up the right to strike: it would weaken the union's negotiating position, it would encourage other employers to demand a similar pattern for collective bargaining, and it could potentially damage the bargaining position of private sector unions across Canada. The debate around the Framework was almost exclusively around the no-strike clause. Even some of those on the left of the union did not see the no-strike clause as the major problem. For Herman Rosenfeld, 'the argument was once you're in, you can build. ... for me, having a no-strike clause for a year wouldn't have been the end of the world.' ${ }^{170}$ While the leadership defended the no-strike clause, the clause in the framework that would prevent workers from electing their own stewards was almost completely ignored in the debate around the Framework. For Rosenfeld, and many others on the left, this was the true poison pill in the Framework: 'it's not just that they weren't elected, is that they

\footnotetext{
${ }^{167}$ Ibid, 28.

168 Ibid, 43.

169 Ibid, 45.

${ }^{170}$ Herman Rosenfeld, in discussion with the author, August 2013.
} 
weren't responsible for representing workers.' ${ }^{171}$ The election of stewards by workers is one of the most basic principles of trade unionism, and giving that up was seen, by many on the left, as a major surrender by the CAW.

The Framework for Fairness was endorsed by the Council. In the wake of the deal, the CAW was unable to organize as many Magna workers as they had hoped. Looking back, many key players in the CAW had mixed feeling about the Framework. Tim Carrie, a major supporter of the Framework at Council, and the President of the Independent Parts Suppliers' Council,

'believed that it gave us an opportunity to get our foot in the door with a major auto parts supplier, and I also felt that it gave us an opportunity to look at the density of unionized workers in the auto parts sector. ... Looking back at it, I mean, was it the best decision? It's hard to say ... but what didn't happen was all the other issues that were supposed to happen after.' ${ }^{\prime 72}$

Chris Buckley would 'still oppose the Framework of Fairness today.' ${ }^{173}$ Carol Phillips, then assistant to Hargrove, was openly opposed to the Framework at the NEB, and remains critical of the decision, as she saw it as a move by the CAW in a more conservative direction, shifting towards a business union mentality: 'what we were doing was moving towards a sweetheart deal with a corporation that would give us ... workers, who would be told to pay dues, instead of organizing them.... And so it was moving way, way towards a business union, and away from social unions, which is what our roots were. It was appalling to me.' ${ }^{174}$ Hargrove remains a supporter of the Framework, ignoring the issue of stewards: 'I still believe that today: it was a legitimate deal that we made, legitimately recognized by the labour movement as part of free collective bargaining. A lot of the unions have demanded arbitration to resolve their issues over

\footnotetext{
171 Ibid.

${ }^{172}$ Carrie, discussion.

${ }^{173}$ Buckley, discussion.

${ }^{174}$ Carol Phillips, in discussion with the author, August 2013.
} 
the years.' $^{175}$

The Framework for Fairness was born out of a desire by the CAW to keep union density high. Plant closures, stemming from divestment in the North American auto industry, had dramatically reduced the presence of the CAW in auto manufacturing. The union was attempting, at this point, to keep its density in the auto and auto parts sectors high, so it could continue to act as a leader in the private sector, and to have the financial base to support the other sectors of the union. The Framework, however, represented a conservative shift within the CAW - closer cooperation with the employer, and a willingness to trade core principles of trade unionism for union density. In a way, the Framework was to organizing what concessionary collective agreements were to collective bargaining - a short term trade-off for immediate results (albeit, in the case of the Framework these results never materialized), with long term negative consequences.

The traditional base of the CAW was automotive workers and workers in the automotive parts sector. In 1991, they represented 57\% of the CAW membership. By 1994, after NAFTA had taken effect, $39 \%$ of the CAW members came from the traditional base and by 1999 , this base had dropped to $38 \%$. At this point, the union stopped tracking the sectors within manufacturing, and simply reported 'manufacturing' as an aggregate category, with 54\% of members working within manufacturing in 2002 . The number declined to a low of $47 \%$ by 2008. ${ }^{176}$ In 1994 the union recognized that there was a major decline in the automotive sectors of the union, but noted that 'auto assembly and parts sector will still employ more than two of

175 Hargrove, discussion.

176 Source: national and area reps reports to constitutional and collective bargaining conventions in the years noted. The full set of number for percentage of CAW members in auto and auto parts are: 1991, 57\%; 1993, $54.7 \% ; 1994,39 \% ; 1996,43.9 \%, 1999,38.7 \%$. After the union switched to simply providing percentages for 'manufacturing', the numbers are 2002, 54\% employed in manufacturing; 2005, 53\%; 2008, 47\%. 
every five CAW members. Bargaining in this sector will continue to have a significant influence on the bargaining programs and success of our union in other sectors of the economy.' ${ }^{177}$ In addition to representing the financial base of the CAW, many major gains for collective agreements across the union, especially with regards to equity, were first negotiated with The Big Three, and then taken to other sectors. While auto was in sharp decline, the relative importance of the auto sector to the CAW was quite large. Organizing and mergers also changed the identity of the union. While organizing in sectors outside of auto, new groups were brought into the union. Women and racialized workers began growing in the union. As the union became less white and less male, it had to struggle with dilemmas of representation; organizing new workers was key to the long-term survival of the CAW, but with new organization meant new groups needed to be represented within the union.

\section{Conclusions}

The CAW was born out of the Canadian UAW's refusal to grant the concessions the American UAW was prepared to go along with. From the very earliest days of the union, the CAW was fought against plant closures and the free trade agreements, which had precipitated ongoing job losses. The union developed numerous strategies to fight free trade and plant closures. Fight back strategies frequently excluded contentious politics - while strikes and plant occupations did occur, they were not the norm - suggesting that the union has always seen, even implicitly, a separation of the economic from the political under neoliberalism. Fight back strategies initially involved collective bargaining - using the bargaining clout to protect against plant closures with strong language. When this failed, the union diversified its tactics, however,

1771994 Convention, President's address, 3. 
they became even less radical. The union placed a great deal of emphasis on awareness campaigns, including lobbying politicians of all stripes to prevent plant closures. As detailed above, in many cases, the opposition to free trade from the leadership within the union amounted to empty words: the leadership knew both they had to speak out against new free trade agreements, but that there was little they could do to stop them from becoming reality.

Quite early on, the union adopted a reliance on electoral politics to fight free trade and plant closures. Owing, in part, to a close relationship with the NDP at the birth of the union, the union saw close cooperation with the NDP as a way to protect CAW jobs. As will be detailed in Chapter five, the union initially promoted the election of a social democratic government, believing that the NDP would protect CAW jobs. As the relationship with the NDP soured, the CAW turned to supporting a strategy of strategically voting for whatever party would support automotive capital - seeing as this would lead to automotive jobs.

The union also sought to bring new members into the ranks, whether through organizing new workplaces or merging with other unions. This strategy led to many new members, but created the dilemma of how to best represent these workers. The changing demographics of the union are detailed in Chapter four. The union remained, primarily, an advocate for manufacturing, although it certainly lobbied and supported all sectors it organized in. A strong manufacturing sector, especially a strong automotive manufacturing sector, would give the CAW the economic clout it needed to act as a strong, socially minded union.

The fight back strategy changed over time. While there were certain cases of union militancy: plant occupations, strikes against plant closures, and the blockade of GM headquarters, for example, the union mostly relied on negotiating collective agreements to prevent plant closures. When this strategy failed, the union began to negotiate strong plant 
closure agreements. As the 2000 s closed, the CAW became increasingly comfortable with granting concessions, although not in the 'core' areas of wages and benefits, to secure production. Short term production was not always secured, however, and the union still faced multiple plant closures a year. 


\section{Chapter Four: Equity, Class, and the CAW}

\section{Introduction}

As Swartz and Warskett astutely note, 'workers, after all, are not only wage labourers; they enter the workplace as complex human beings with a range of economic, social, political, and cultural interests.' ${ }^{1}$ While trade unions primarily organize workers as wage labourers, they are also faced with the challenge of recognizing the other range of identities that workers have, especially identities that have traditionally been marginalized in both the workplace and broader society. Equity issues in trade unions are complex, and the degree to which a union takes action, the type of action it takes, and the seriousness with which it undertakes it's course of action are based on a number of interconnected factors: the extent of demographic change, the institutional capacity for building activist presence around new equity issues, the support of current union leadership, and the embeddedness of a distinct labour culture. ${ }^{2}$ All of these factors were present in the CAW albeit in different degrees.

This chapter is concerned with how equity seeking groups prodded the union to act and how equity was seen through a class lens within the CAW. As the previous chapter argued, the CAW's membership has shifted from predominantly white and male to an increasingly diverse base as it sought to compensate for job loss in the automotive sector. As Offe \& Wisenthal argue, this expansion can lead to collective action dilemmas, as the union would have to respond to a diverse and growing set of demands. As I argue, the Council provided the CAW with the institutional capacity for building activist presence around new equity issues. Equity issues

\footnotetext{
${ }^{1}$ Donald Swartz \& Rosemary Warskett, "Canadian Labour and the Crisis of Solidarity" in Rethinking the Politics of Labour In Canada, eds. Stephanie Ross \& Larry Savage (Halifax: Fernwood Publishing, 2012 ), 19.

${ }^{2}$ Gerald Hunt, "Introduction," in Equity, Diversity, and Canadian Labour, ed. Gerald Hunt and David Rayside (Toronto: University of Toronto Press, 2007), 14.
} 
found their way to the floor of the council, were discussed in President's reports and staff reports, and activists in the $\mathrm{CAW}$ found the structures of the council open to equity caucuses. This is consistent with Sabel's argument about the role intermediate groups play. Finally, as this chapter argues, the embeddedness of a culture of working class strength and one of 'fighting back' allowed for equity to be articulated as an important issue of working class based solidarity for all CAW members.

Douglas' concept of bricolage - the combining of available and legitimate concepts found in an institutional environment to symbolically link a key event to a larger issue - sheds light on the way the CAW dealt with equity issues. Racial equity in the CAW was linked to the struggle against Apartheid in South Africa, women's equity was linked to the Montreal Massacre, and LGBTQ politics were symbolically linked to the case of Marc Hall. Equity issues developed slowly but steadily over the course of the CAW's existence. While there was some overlap between the three main equity issues this chapter explores - racial equity, women's equity in the union, and equity for the LGBTQ community - generally these issues unfolded in succession, with racial equity being a more pressing issue in the 1980s to early 1990s, gender equity throughout the 1990s, and the LGBTQ community finding a space in the union from the late 1990s through to the present. The CAW was often at the forefront of equity issues, usually well ahead of other Canadian industrial unions.

This chapter argues that the leadership of the union played a key role with equity issues within the union, especially at CAW Council. There is a long history of equity seeking groups, especially women, challenging the structures of the union (detailed below). More recent developments regarding equity in the CAW saw the leadership channelling the position of equity activists back to the membership, in an effort to build a more inclusive union. Generally issues 
of equity were quite strongly championed - by national and local leadership, who were often pushed to take strong positions on equity issues by activists within the union. For example, the presence of strong feminist women as staff raps in Carol Phillips and Peggy Nash helped guide the national leadership's position on equality for women in the union.

The first section focuses on the CAW and international solidarity. Although the latter may not seem to be directly related to equity issues, it provides an important context for the next section on racial equality in the CAW. In other words the CAW forged a link between the struggle against Apartheid in South Africa to the struggle of racialized workers everywhere The third section picks up on the earlier discussion of gender and women's equality in the CAW while the final section examines the LGBTQ movement and the CAW. ${ }^{3}$

\section{International Solidarity, Human Rights, and the Struggle against Apartheid}

From the outset, the CAW had a strong commitment to international solidarity and it articulated this as part of its solidarity with a global working class. ${ }^{4}$ Through the 1980 s the CAW's international solidarity work involved participation in boycotts organized by other labour organizations such as the USWA's boycott against Radio Shack and Cesar Chavez's boycott against California grapes. ${ }^{5}$ Since its birth, the CAW has had an active history of sending delegations of CAW members abroad to discuss common problems and solutions with other trade unionists. For example, in 1985 CAW members participated in a solidarity trip to Chile to

${ }^{3}$ Of course, equity politics within the CAW were not limited to racialized workers, women workers, and LGBTQ workers. There was a long commitment to aboriginal communities by the CAW, including support of first nation sovereignty and a long standing participation in the Free Leonard Peltier movement. Near the end of the CAW, there was a growing interest in Youth workers. For the purposes of brevity, however, this chapter will focus on racalized, women, and LGBTQ workers.

${ }^{4}$ This chapter provides a very brief overview of the international solidarity work of the CAW. Not all of the work is listed here. The CAW frequently donated funds to causes overseas, and the struggles of working people, trade unions were often present in President's reports. While it is a disservice to the history of the CAW that I cannot list them all here, I have chosen to only highlight major issues for the purposes of brevity. 
meet with Chilean trade unionists. Members returning from such trips provided reports to the Council. ${ }^{6}$ This shows a very real commitment by the CAW to strengthening bonds between trade unions and unionists, often in places where trade unionists faced severe repression.

The union's early international solidarity work, which was maintained throughout its history, shows a commitment to the creation and maintenance of international working class political ties. The strength of the commitment to issues of international solidarity is linked, very closely, to the union's embrace of racial equality.

The first sustained campaign of international solidarity undertaken by the CAW was through its participation in the struggle against Apartheid in South Africa. In this period the Apartheid regime was coming under increasing international criticism but in many respects, Canada was a global leader in this campaign. Thus Progressive Conservative Prime Minister Mulroney took a stance against Apartheid when other conservative world leaders were supportive of the regime. If the Canadian government was a leader in this campaign, the CAW remained a leader within Canada on this issue.

The CAW maintained a strong commitment to ending Apartheid, arguing that the CAW needed to support the end to Apartheid as part of a project of global emancipation of the working class. In his first report as the President of the independent Canadian union, Bob White highlighted the struggle against Apartheid and pushed the CAW Council to endorse resolutions supporting the end of racial segregation in South Africa. A delegation from SACTU was invited to address CAW members at the first meeting of the CAW Council. ${ }^{7}$ White and the leadership of the CAW more broadly saw Apartheid in class terms, arguing in the CAW Council that the

\footnotetext{
${ }^{5}$ December 1985 Council, President's report, 30 -31.

${ }^{6}$ December 1985 Council minutes, 45.
} 
oppression of the Black majority in South Africa was rooted in capitalism and that the end of Apartheid would be a victory for the South African working classes. To this end, the CAW partnered quite closely with SACTU, often featuring reports from the trade union in reports to Council. White also featured the struggle against Apartheid frequently and prominently in his reports to council.

In addition to educating the members of the union on Apartheid, the CAW took an active role in the international struggle against the regime. In 1986, when the Council meet in Toronto, the CAW participated in a demonstration against the South African Consulate, and endorsed SACTU's boycott against South African goods sold in Canada. ${ }^{8}$ In 1988, when White reported to the council that the situation in South Africa was 'getting worse,' Council recommended condemning 'the latest crackdown in South Africa and Call on the Mulroney Government to impose total sanctions against South Africa.' 9

While the Council supported this recommendation, the debate surrounding it revealed some of the limits of the CAW leadership's thinking on international solidarity. Thus when a brother at the council criticised White for not including the Israelis who 'are outdoing the South Africans ${ }^{10}$ - White rejected this, arguing:

'That is separate ... I am not recommending that we put the Israeli question here, nobody is talking about economic sanctions against Israel today and it doesn't make any sense to do that, we are talking about South Africa, where the Government is practically saying the apartheid on the basis of the colour of your skin ... The situation in Israel is a different situation. ${ }^{11}$

It would not be until 1988 that White condemned the treatment of Palestinians by Israelis as a

\footnotetext{
${ }^{7}$ March 1985 Council, President's Report, 13.

${ }^{8}$ March 1986 Council minutes, 1.

${ }^{9}$ March 1988 Council minutes, 11.

${ }^{10}$ Ibid.

11 Ibid.
} 
form of apartheid. ${ }^{12}$

In 1990 the CAW successfully negotiated with the Big Three for the creation of the 'CAW Social Justice Fund'. The auto companies, who contributed the lion's share to the fund, would provide one cent per straight time hour worked towards a fund to provide humanitarian relief and development assistance. . ${ }^{13}$ The fund enabled the CAW to donate approximately $\$ 1$ million a year. ${ }^{14}$ The Social Justice Fund thus provides another example of how the material strength of automotive manufacturing provides an avenue for the CAW to carry out the work of social unionism. .

During the 1990s, , however, attention within the CAW shifted away from international politics, leaving the Fund - and the national executive and staff - to do the union's international work. While the use to which the Fund was put was reported to the council, it was the national executive and staff that increasingly were in charge of dispensing the funds. The president's reports focussed less on international politics, there was less debate on international politics at Council, and few recommendations regarding international solidarity were brought forward. ${ }^{15}$ Although the union remained quite active in international humanitarian aid throughout this period - for example, the CAW was the largest contributor to the land mine removal initiative of the Chretien government ${ }^{16}$ - international concerns were no longer central to its agenda.

${ }^{12}$ March 1988 Council, President's report, 25.

${ }^{13}$ December 1991 Council, national and area staff reps report, 27.

${ }^{14}$ Buzz Hargrove, Labour of Love, (Error! Main Document Only.Toronto: McFarlane Walter \& Ross, 1998), 132.

${ }^{15}$ It was during this time that there was a leadership change in the CAW - Buzz Hargrove replaced Bob White as president of the union. Hargrove remained fully committed to international issues, but much of his leadership focused on building racial equality within the CAW. It is unclear how much of the shift away from international politics is due to a change in leadership, and how much is due to the Fund being the institutional home of international politics.

${ }^{16}$ Buzz Hargrove, Laying it on the Line: Driving a Hard Bargain in Challenging Times (Toronto: HarperCollins, 2009), 45. 
International politics and human rights came back onto Council's agenda following 9/11, when the CAW opposed the invasions of Afghanistan and Iraq and frequently spoke out against the curtailment of civil liberties in Canada. The December 2001 Council, the first Council following 9/11, was dominated by opposition from the floor to both overseas war and the clamping down of civil liberties by the Canadian state. In particular, Buzz Hargrove likened the proposed restrictions on civil liberties to the use of the War Measures Act, to suggest that the ramifications would go well beyond the legislation 'only being used against terrorists.' ${ }^{17}$ Race, Racism, and Ethnicity and the CAW

Marie Clarke Walker argues that 'the labour movement ... is a microcosm of society and, similar to other organizations, unions reflect the society in which they exist. Therefore, the behaviours and comments seen and heard inside and outside the movement are often the same. Racism manifests itself in the union movement. ${ }^{18}$ The UAW had faced the challenges of racism within the labour movement much earlier than the CAW. The overt racism in American civil society and the workplace before the Civil Rights movement of the 1960s meant that issues of racism within the UAW and American workplaces were on that union's agenda well before the CAW grappled with this challenge. The CAW did however set out to deal with the dual issues of racial discrimination in the workplace and within the union in the early years following the split from the UAW. White explicitly called on the CAW to fight racism within the union: 'at times Canadians feel very smug about racism, but the facts are it is in our society, in our workplaces and in our police forces. As we are internally working to change those attitudes within our union, so must the law enforcement agencies change to reflect the new reality of

\footnotetext{
${ }^{17}$ December 2001 Council minutes, 47.

${ }^{18}$ Marie Clarke Walker, “Are We There Yet? The Struggle For Equity in Canadian Unions," in Unions,
} 
Canadian life and culture.' ${ }^{19}$ The anti-racism work within the CAW was carried out to the workplace, first at the Big Three, and then to other CAW locals.

Initially, the CAW framed the issue as part of the larger international struggle against Apartheid. The message from the CAW leadership was along the lines of "if you think what is going on in South Africa is awful, you should work to eliminate racism here at home, as well as abroad." In 1986 the CAW Council passed a recommendation to send a letter of protest to then British Columbia Premier Vander Zalm, opposing his support for the expansion of trade with South Africa. ${ }^{20}$ At the same Council, the leadership began to highlight issues of racism and racial discrimination in Canada. It also passed a resolution to set up 'English in the workplace' training to help ESL members learn English. The Council featured a great deal of debate surrounding the importance of this program as a way of preventing the division of the working class in Canada along racial or ethnic lines, or discriminating on the basis of language. ${ }^{21}$

While apartheid was not often explicitly mentioned in relation to the anti-racism work of the CAW in the union and in Canada, clear connections were drawn. Recommendations were strategically linked: there would often be a recommendation to support the struggle against apartheid followed immediately by a recommendation about fighting racism in Canada. White's speeches and reports frequently started with updates on Apartheid, and would then immediately lead into a discussion about racial equality within the CAW. The connection was clear: racism must be fought on many fronts, within the union, within Canada, and internationally, all at the same time.

\footnotetext{
Equity, and the Path to Renewal, eds. Janice R Foley \& Patricia L Baker, (Vancouver: UBC Press, 2009 ), 89.

${ }^{19}$ February 1989 Council, president's Report, 34. The comments about law enforcement relate to a task force on race relations for Ontario police.

${ }^{20}$ December 1986 Council minutes.

${ }^{21}$ Ibid.
} 
For the CAW the struggle against racism, and discrimination based on ethnicity, had a material basis and was part of a larger project of working class solidarity rooted in Canadian realities. In particular, its Quebec membership helped to highlight the importance of respect for linguistic rights. In 1990 municipalities in Quebec were proposing bylaws for 'English only' service. The CAW opposed these bylaws and the membership at Council clearly articulated the opposition in class terms: 'racism - what have we learned in human rights courses? Racism is a pillar of capitalism and this is another attempt to divide working people on an issue of language. ${ }^{22}$ Another member clearly outlined the relationship between class, language, and racism:

'One of the lessons that we should understand, fundamentally, is that the question of language rights in Quebec has always been a working class issue. If you look into the history of the UAW in Quebec, we can look at some pitched wars that were fought over language rights against corporate arrogance. We had battles in our union history over the right of workers to be communicated at work in their own language. ${ }^{23}$

Hargrove's first speech as president of the CAW indicated that the struggle against

racism would be among the most important issues for him as leader of the union:

'the recognition and rights of visible minorities, and the problems of racism and sexism in our communities, in our workplaces and in our local unions and national union - there is no issue more pressing for our union. All members and workers in CAW must be assured that regardless of their colour of their skin, their religion, sexual orientation, or their disability, whether they are women or men, they will get respect and fair treatment in CAW workplaces, local union halls and from the national union. ${ }^{24}$

Through the 1990s, under the leadership of Hargrove, the union greatly expanded its antiracism activities. In 1991, when a person of colour was added to the National Executive Board,

\footnotetext{
${ }^{22}$ February 1990 Council minutes, 13.

${ }^{23}$ Ibid.
} 
the union treated this as much more than a symbolic move, noting that the equity reps on the NEB were 'actually debated and listened to.' ${ }^{25}$ Starting in 1990, the Human Rights Training package, which contained anti-racism modules, was offered more frequently as part of the Paid Education Leave program. ${ }^{26}$ In 1992, this was expanded into a two week training program for Workers of Colour and Human Rights Training in the area of collective bargaining, with the collective bargaining course being targeted at executive board members and chairpersons of bargaining committees. ${ }^{27}$ The Human Rights Training program was eventually expanded into a one-week program, which, as of 2012, is required for all elected executive members in the union, the rational being that 'as an elected or appointed person, I'm actually going to have to uphold human rights, so I will need training for that. ${ }^{28}$

The membership of the CAW was, by this point, seeing racism in explicitly class terms, and that anti-racism is required for class-based solidarity. As one delegate to Council articulated

'we live in a racist society, racism affects and infects our membership to varying degrees ... Without waging that battle in our own union, without succeeding in that, we will be much weakened in the face of the battles that we have ahead. The working class in this country is changing, it comes in all colours and in all national origins. If we want to unify the working class, we have to free ourselves of racism. ${ }^{29}$

In 1993, a visible minority caucus began to meet at Council, and in November of 1994130 members of the CAW attended the union's first-ever Workers of Colour Conference. The caucus meets during Council, and has the power to make recommendations to the larger union,

\footnotetext{
24 June 1992, Special One Day Council, Buzz Hargrove’s Speech, 27.

${ }^{25}$ Vinay Sharma, in discussion with the author, July 2013.

${ }^{26}$ December 1990 Council, national and area staff reps report, 4.

${ }^{27}$ August 1992 Council, national and area staff reps report, 2 - 3.

${ }^{28}$ Sharma, discussion.

${ }^{29}$ December 1992 Council minutes, 73.
} 
which then debates and decides these recommendations. ${ }^{30}$

It was the union's goal to not only provide a space for racialized workers to organize within the union and to do anti-racism work among the members of the union, but also to organize racialized workers as a political unit within the CAW. This was done primarily through the national Human Rights committee and the PEL Workers of Colour program. Graduates of the Workers of Colour program, along with other racialized members of the CAW, established caucuses around the country to encourage racialized workers to become active in the union, to seek leadership positions within the CAW, and to participate in campaigns to both organize new members, and to organize the organized. ${ }^{31}$ Bonds of solidarity were created between workers in the union, with the goal of strengthening the culture of fighting back that was central to the CAW. While the union not only had a clear commitment to advancing racial equality within the union, it was committed to using its industrial strength to improve the material conditions at work for racialized members.

As is the case with most of the equity-based bargaining, bargaining for specific considerations for racialized workers began at The Big Three. In the 1992 round of collective bargaining in auto, the CAW negotiated 'a detailed anti-harassment policy which committed the company to ensure a harassment-free workplace. It also provided for a joint procedure to investigate and resolve harassment complaints. ${ }^{32}$ The anti-harassment language was made a priority and was eventually extended to nearly all locals in the CAW. ${ }^{33}$ The anti-harassment policy was a top priority to the union, signalling how important the issue had become to the

\footnotetext{
${ }^{30}$ Sharma, discussion.

${ }^{31}$ December 1995 Council, national and area staff reps report, 30.

32 December 1993, President's report, 13.

33 Sharma, discussion. Sharma suggests that he "hesitates to say $100 \%$ [of locals have the language] because we are a union of many mergers, and there's collective agreements I have not seen ... It's probably in every
} 
leadership. The leadership of the union saw advancing equity language to be as important as negotiating for job security, wage increases, and other "bread and butter" trade union issues. Indeed, the staff of the union recognized that 'during tough economic times, some tend to view human rights and women's rights as frills that can be dropped from the bargaining table early on,' but Hargrove and the Chrysler bargaining chairperson both ensured that anti-harassment language was included in the final settlement with the auto manufacturers. ${ }^{34}$ Bargaining for human rights language has generally started within the Humans Rights department of the union, which would craft specific language, which would then be passed to locals engaged in bargaining through the National Reps. ${ }^{35}$

Racialized workers were given the space and resources necessary to organize within the union, and were encouraged to do so by the leadership. The union also used its significant industrial strength to bargain for better conditions at work for racialized members, starting within auto and branching out from there. Racism was articulated, initially by the leadership and staff, and later by the rank-and-file, as endemic to capitalism, and a means of dividing the working class. The CAW's anti-racism approach was materialist and class-based, and was part of a larger framework of class-based solidarity and a fight-back strategy.

\section{Gender Equality and the CAW}

The UAW, and then the CAW, have both been characterized by a 'male-dominated culture, tough for women to break through. ${ }^{36}$ From the start, however, the CAW worked for gender equality, with White championing gender equality and appointing feminists to top

collective agreement."

${ }^{34}$ December 1993 Council, national and area staff reps report, 6 .

${ }^{35}$ Sharma, discussion.

${ }^{36}$ Peggy Nash, in discussion with author, July 2013. 
positions within the union. The push for gender equality in the CAW followed a very similar path to that of racial equality. Women workers historically had struggled to carve out a place within the union and to fight gendered structures, practises, and assumptions within the union. One of many the results was the presence of feminist women in positions of influence within the union. In particular, Carol Phillips and Peggy Nash, two feminists who were assistants to the national president, played important roles in helping to push for broader gender equality within the CAW. Gender equality thus found champions in the leadership and staff of the union and was extended through the structures of the union over time. Women's equality in the CAW was framed along the contours of working-class feminism and, as in the question of race, gender equality was represented as a class issue. This meant that the CAW emphasized material advances for women in the workplace and in the broader Canadian society.

The 1980s also saw the Canadian UAW make strides in the area of equity politics. In 1983 the union became the first private sector union to negotiate a daycare fund at Canadian Fab in Stratford, Ontario where the employer agreed to pay two cents per hour per worker. The union later expanded this child care fund with the Big Three in $1989 .{ }^{37}$ The mid-to-late 1980s saw the CAW take on the issue of employment equity. The UAW had long sought to organize the entire shop floor into one bargaining unit in order to standardize rates of pay across the plant. If women worked in the same job classification as men, they received the same pay, but this was not often the case: women were routinely occupationally segregated from men, meaning they often did not receive equal pay for work of equal value. ${ }^{38}$ The UAW, along with other industrial

\footnotetext{
${ }^{37}$ Julie White, Sisters \& Solidarity: Women and Unions in Canada (Toronto: Thompson Educational Publishing, 1993), 91.

${ }^{38}$ Rosemary Warskett, "The Politics of Difference and Inclusiveness within the Canadian Labour Movement," Economic and Industrial Democracy 17 (1996): 597.
} 
unions, had long supported equal pay for equal work, as industrial unions saw that business would often try to pay women less, thus undercutting the wages of workers. The issue of employment equity, enabling women and other disadvantaged workers to take an equal place in the labour force, however was more challenging for unions. Many industrial unions faced opposition 'to employment equity among their own ranks. Insisting upon hiring, training, and increasing opportunities for women and minority groups may be unpopular among the established work force. ${ }^{39}$ While the CAW was undergoing the often slow process of changing the internal culture of the union, in an attempt to be more open to equity seeking groups, the union also fought to win employment equity in their collective agreements.

One of the earliest victories for employment equity for the CAW was the negotiation of an affirmative action program with General Motors in $1984 .{ }^{40}$ At this time women represented just $10 \%$ of GM workers, and only $1 \%$ of skilled trade jobs. While the union was successful in establishing affirmative action committees, GM resisted the union's demands for employment equity goals and timetables. ${ }^{41}$ In 1987 the union was, again, unable to win specific employment equity targets and timetables, but was able to win three hours of human rights training for every GM employee, a literacy program, teams to work on harassment at the plant level, and an employee child care fund ${ }^{42}$ - all major victories for equity at the plant level.

While the CAW has won limited employment equity provisions, Warskett noted that, through legislation, employment equity has been 'largely ineffective in the face of economic restructuring in the private sector and cutbacks in the public sector. ${ }^{43}$ This highlights the

\footnotetext{
${ }^{39}$ White, Sisters \& Solidarity, 76.

${ }^{40}$ Ibid, 77.

${ }^{41}$ Ibid.

${ }^{42}$ Ibid, 78 .

${ }^{43}$ Warskett, "The Politics of Difference," 590.
} 
importance of bargaining for employment equity at the workplace, and links into the broader CAW political strategy of resisting the facets of economic restructuring that lead to major changes in the workplace. The push for pay equity in the workplace opened up the union to challenges to their own labour practises. As Kainer argues, 'pay equity provided the political space for union women to push forward on equity demands both in the area of labour market policy and in regard to internal union policy. ${ }^{44}$ Pay equity was born out of an attempt by the union to protect the wages of their members - prevent the employer from hiring women, racialized, or young workers to undercut the pay of white men.

The push for pay equity, following the ideals of working class feminism that Maroney described, allowed for women activists to begin to challenge the union as a whole to be more inclusive and equitable in its own practises. Warskett shows that through the 1980 s union feminism

'demanded a broader approach to bargaining demands, union policy and participation by the membership, criticizing the limitations of the process and policies traditionally found within the movement. ... Union feminists targeted policies as a beginning to changing the subordination of women in the workplace, in the unions, and in the home. This involved addressing women's triple day as union activists, and devising policies which relieved women of their duties in the home, such as the provision of paid childcare during union events. ${ }^{, 45}$

By the late 1980s the CAW was one of only four unions to have a representative number of women on staff, and was the only union to mandate women's committees at the local level. ${ }^{46}$ White also shows that through the end of the 1970s through to the beginning of the 1990s unions in Canada had great movement towards representative numbers of women on union executives

${ }^{44}$ Jan Kainer, "Gendering Union Renewal: Women's Contributions to Labour Movement Reviatlization" in Unions, Equity, and the Path to Renewal, eds. Janice R Foley \& Patricia L Baker, (Vancouver: UBC Press, 2009), 21.

\footnotetext{
${ }^{45}$ Waskett, "The Politics of Difference," 611- 612.
} 
(although representativeness had not been reached by 1990), the CAW included. ${ }^{47}$ Changing the internal culture of unions is of the upmost importance when it comes to equity issues. Besides attempting to language at the bargaining table unions must seek to change the way both rankand-file and leadership members approach equity issues. This is especially true given that, in general, private sector unions have been less favourable to the principles of employment equity than public sector unions have been. 'Union campaigns supporting employment equity, affirmative action, peace, and native self-determination didn't seem to fit well into the internal union political culture. ${ }^{48}$

From the first months of the CAW's existence, considerable importance was attached to the position of women workers and the need for equity. White identified women's equality as a key issue of his presidency ${ }^{49}$. At the June 1985 Council, delegates received a report from striking Bank of Commerce Visa Centre workers, organized by the Union of Bank Employees. The bank workers, $80 \%$ of whom were women, were striking primarily for wage increases. While it would not be uncommon for a union to provide details on a strike to another union, the way this particular strike was dealt with reflects the way the union saw gender equality and antisexism through a class lens, a lesson learned during the Fleck strike. The staffer who provided the report to Council told members it was important to support the women workers in their struggle against the bankers, who were referred to as 'the capitalists of the world. ${ }^{50}$

Within the CAW, there was a continual push for more - and more meaningful -

${ }^{46}$ White, Sisters In Solidarity, 116, 126.

${ }^{47}$ Ibid, 99.

${ }^{48}$ Abigail B Bakan \& Audrey Kobayashi, "The Sky Didn't Fall': Organizing to Combat Racism in the Workplace - The Case of the Alliance for Employment Equity" in Race, Racialization, and Antiracism in Canada and Beyond, eds. Genevieve Fuji Johnson \& Randy Enomoto, (Toronto: UTP, 2007), 60.

${ }^{49}$ Carol Phillips, in discussion with author, August 2013.

50 June 1985 Council minutes. 
representation for women. White appointed a number of women to staff positions, and made it 'quite clear that not only did he want women on staff, he wanted women who understood they needed to bring feminist principles.' ${ }^{51}$ In 1987, the bylaws of the Council were changed to ensure that at least one of the three trustees of the Council would be a woman, ${ }^{52}$ marking the first time that women were guaranteed representation among the leadership of CAW council. The CAW also established an annual Women's Conference. By 1999 this had expanded to an annual Women's Conference and five regional women's conferences. In 2001 the Women's Department was established as a full-time department in the union, ${ }^{53}$ responsible for the annual women's conferences, the PEL programs relating to women, and collective bargaining goals for women. With respect to collective bargaining, the Women's Department worked in tandem with the Human Rights and Pride departments to develop a holistic equity chapter of bargaining goals. $^{54}$

The early gender politics of the CAW were largely based on substantive, work-related goals for women in the CAW and in Canada as a whole. For example, in 1987 the CAW called for universal child care in Canada, seeing it as both a "women's issue" and an issue of importance to the broader working class. ${ }^{55}$ Its critique of free trade was linked to women's material well-being. The campaign against free trade was given its gender dimension by Carol Phillips, a feminist and assistant to White, who noted that a free trade deal could see the

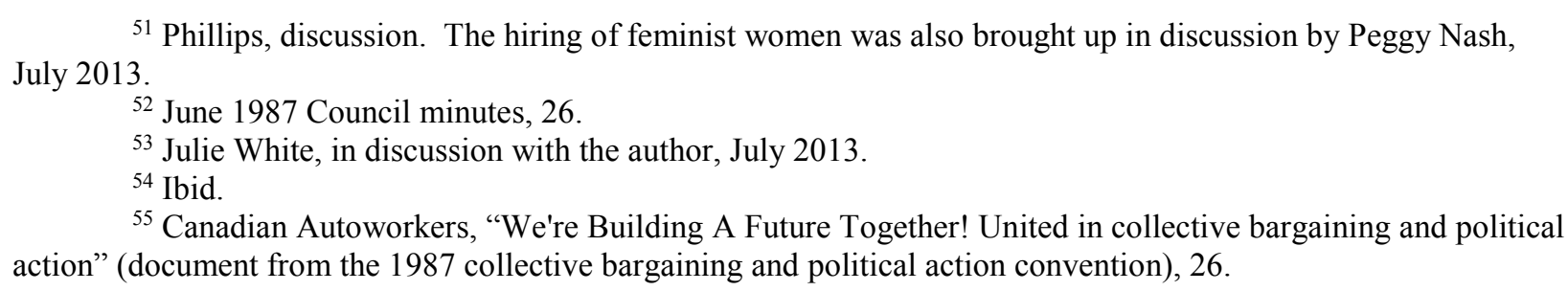
July 2013

${ }^{51}$ Phillips, discussion. The hiring of feminist women was also brought up in discussion by Peggy Nash,

52 June 1987 Council minutes, 26.

53 Julie White, in discussion with the author, July 2013.

${ }^{54}$ Ibid.

${ }^{55}$ Canadian Autoworkers, "We're Building A Future Together! United in collective bargaining and political action" (document from the 1987 collective bargaining and political action convention), 26. 
destruction of $40 \%$ of women's jobs in manufacturing in Canada. ${ }^{56}$ In this way, women's issues were linked to the major political struggle - opposition to free trade - of the union. Women's issues were articulated as substantive, monetary, and one-in-the-same as the issues of the union.

White continued to champion feminist issues within the union, encouraging it to face the sexism present within its ranks. White articulated these issues as not only important to women, but also as challenges for the working class. For example, in his September 1989 report to CAW Council, he indicated his strong support for the campaign for women's right to choose, arguing that access to abortion was not only a women's issue, but a working class issue: 'believe me, if women don't have the right to control over their bodies, it will be working class women who lose out because the rich will always be able to go where facilities are available. On October 14, there will be several pro-choice rallies in major cities across Canada and we should participate in support of this important issue.' ${ }^{57}$ In early 1990, when the NDP was concluding a leadership race, White spoke out against sexist remarks CAW members made against NDP leader Audrey McLaughlin, and went on to suggest that there was a great deal of sexism within the CAW that needed to be eliminated. ${ }^{58}$ White argued that there was an immediate and pressing need to change the culture of the CAW.

While there was thus a long tradition of taking gender seriously within the CAW, the work to eliminate sexism with the union came to a forefront after the events of the Montreal Massacre, which were symbolically linked to sexism and gender inequality within the union, workplaces, and in Canadian society as a whole. On 06 December 1989, Marc Lépine entered École Polytechnique in Montreal, killing fourteen women and injuring ten women and four men

\footnotetext{
${ }^{56}$ December 1987 Council minutes, 55.

${ }^{57}$ September 1989 Council, President's report, 7.
} 
before turning the gun on himself. Lépine specifically targeted women, claiming feminism had ruined his life.

The Montreal Massacre became a watershed for the CAW, as it was seen as symbolising a broader sexism in Canadian society and the everyday violence against women. The CAW leadership, particularly women in leadership roles in the union, used the Montreal Massacre as a rallying cry for change. As Briskin has noted, the union's increasing involvement in issues around violence against women has seen campaigns 'go well beyond a focus on employer harassment or even co-worker harassment, and many have successfully integrated issues around racial harassment and violence. ${ }^{59}$ This is certainly the case with the CAW and the aftermath of the Montreal Massacre: the shooting in Montreal led, both directly and indirectly, to a number of changes within the union, to the collective bargaining agenda with employers, and to the way the union approached issues in broader Canadian society.

At the December 1990 council, CAW members passed a recommendation that the union urge the federal government to establish a commission on the violence against women. ${ }^{60}$ At the December 1990 Council, the union also adopted a minute of silence to commemorate those lost in the Montreal Massacre as well as for all other victims of violence against women and from that point every December council began with a minute of silence. A year later, the union announced a 'breaking the silence' campaign to counter violence against women. ${ }^{61}$ The CAW also established a national conference on the issue of violence against women, becoming the first

${ }^{58}$ February 1990 Council, President's report, 38 - 39.

${ }^{59}$ Linda Briskin, "The equity project in Canadian unions: confronting the challenge of restructuring and globalisation" in Gender, Diversity and Trade Unions: International Perspectives, eds. Fiona Colgan \& Sue Ledwith, (New York: Rougledge, 2002), 34.

${ }^{60}$ December 1990 Council minutes, 16.

${ }^{61}$ December 1991 Council, national and area staff reps report. 
union in Canada to do so. ${ }^{62}$

The issue of accommodating women on the shop floor was directly tied to the Montreal Massacre - indeed, the Montreal Massacre was the 'catalyst' for the women's advocate program. ${ }^{63}$ In the years immediately following the Montreal Massacre, the CAW showed a strong commitment to fighting sexism within the union, to improving the working conditions of their members, and to being allied with, or leading, social movements in Canada concerned with women's equality. In 1992 its Paid Education Leave program for the first time offered a Women's Activists Program, ${ }^{64}$ which would go on to become one of the most successful education programs created by the CAW. Much like the Workers of Colour program, the Women's Activist Program had as its primary goal to encourage women to take leadership roles in the union across the country ${ }^{65}$ by showing role models to women who very often never saw women in leadership at the local level, and encouraging them to become leaders. ${ }^{66}$ In addition to concrete skill-building, like public speaking, collective bargaining skills, and how to navigate a membership meeting, and the politics of the CAW. ${ }^{67}$

The CAW also brought issues to the forefront of their bargaining agenda in the 1990s, showing a very real commitment to using its economic power to improve the conditions of women workers. To be sure, while the union was often slightly ahead of the law and somewhat ahead of other major unions in Canada, it frequently lagged behind the women's movement. The CAW would often be slightly ahead of legislation when it came to equity issues and would use

\footnotetext{
${ }^{62}$ December 1991 Council minutes, 23 - 24.

${ }^{63}$ White discussion Ibid.

${ }^{64}$ August 1992 Council, national and area staff reps report, 2.

${ }^{65}$ December 1994 Council minutes, 157.

${ }^{66}$ Phillips, discussion.

${ }^{67}$ White, discussion.
} 
legislation to push equity language further. ${ }^{68}$ Its ground-breaking Women's Advocate program trained women CAW members to become employment equity representatives on the plant floor, with the goal of providing assistance to women facing harassment in the workplace or abuse at the home. Women had the right to refuse work if they were being sexually harassed. Perhaps most importantly, women whose performance or attendance at work was affected by a situation of violence or abuse in at home would not be disciplined by the company. ${ }^{69}$ The woman's advocate acted as a 'buffer' between the woman and management, helping to secure time off the job, as well as acting as a community support person. ${ }^{70}$ The Women's Advocate program used feminist approaches to dealing with violence against women as its starting point. 'The main role of the advocate is to act as a referral agent for a woman "in crisis" who is dealing with issues of violence, abuse or harassment at home or at the workplace. ... She acts as a buffer at the workplace, intervening on behalf of the woman to management to arrange time off without the fear of being disciplined. ${ }^{, 71}$ Woodhall and Leach found that there has been largely positive feedback from women within the CAW on their experiences with the Women's Advocate program. $^{72}$

In addition to negotiating these very real accommodations for those facing abuse, the CAW negotiated a minute of silence on the shop floor on December $6^{\text {th }}$, four hours of antiharassment training for every union member, and language requiring the training of leadership women to be advocates for others in their workplace who are facing harassment or abuse. ${ }^{73}$ The

68 Ibid.

${ }^{69}$ Hargrove, Labour of Love, 120;. December 1993 Council, President's report, 15.

${ }^{70}$ White, discussion.

71 Julia R. Woodhall \& Belinda Leach, "Who Will Fight For Us? Union Designated Women's Advocates In Auto Manufacturing Workplaces," Just Labour: A Canadian Journal of Work and Society 16 (Spring 2010): 52

72 Ibid, 54.

${ }^{73}$ December 1994 Council, President's report, 42; December 1996 Council, national and area staff reps 
union initially secured these programs in the auto sector but then rolled out to other bargaining units in the union. The December $6^{\text {th }}$ Massacre was the catalyst for the Women's Advocate program, but the program quickly expanded beyond issues of violence against women. 'The idea of a women's advocate also addresses the broader problem of unequal power relations between men and women that exist in the home, in a union local, and within labour-management relations. ${ }^{74}$ In this way, the Women's Advocate program is connected to the idea of working class feminism that historically grew within the CAW: the program challenged the notion that home life and work life were separate and distinct, and was used to challenge power relations along both class and gender lines. Julie White, the head of the CAW Women's department expressed 'disappointment' that 'the broader labour movement hasn't picked up on the Woman's Advocate program. ${ }^{75}$

White clearly saw violence against women as a major issue, and one in which the male leadership of the union had a clear responsibility to change. In 1991 he urged 'local leaders and staff speak out on harassment and violence against women, at membership meetings, educationals, and in local union publications. ${ }^{96}$ When Hargrove became national president, he outlined the major strides that the CAW had undertaken to better represent women, and recommitted the CAW to policies of anti-sexism and support for women's rights:

'We have come a long way on women's issues - as one of the leading industrial unions to appoint women to staff positions and to guarantee a minimum of two spots out of 13 on the NEB. We adopted an affirmative action policy and bargained it with the major corporations. We adopted a sexual harassment policy and we fought for pay equity legislation. We more recently have led the way in a campaign to stop violence against women. We were one of the

report.

\footnotetext{
${ }^{74}$ Woodhall \& Leach 55

${ }^{75}$ White, discussion.

${ }^{76}$ Ibid.
} 
first unions in Canada to adopt a policy respecting the rights of women in Canada to have control over their bodies - a pro-choice policy that I will continue to defend as long as I am president of our union. ${ }^{, 77}$

The commitment to real material advances for women, including protection for members facing violent relationships, was renewed as a key collective bargaining goal in the early 2000s. The union was explicit about its commitment to employment equity: 'our commitment to the principle of equal pay for work of equal value means we negotiate pay equity plans whether or not there is a legal requirement to do so. ${ }^{978}$ Women's issues were placed front and centre in the collective bargaining strategies of the 2000s, beginning in the automotive sector but with the aim of then extending these gains to other areas organized by the union. Goals included opening up hiring so that women could get jobs that would enable them to be financially independent; sickness and accident coverage from the first day of entrance into a women's shelter; women advocates in workplaces; protection against discipline from members who are in violent relationships: absenteeism or poor work performance. ${ }^{79}$

The CAW leadership was quite clear about its support for women's equality, both within the union and within the workplace, and that it saw this as a class issue. For instance, in 1996 the CAW National Executive Board condemned the justice system for failing to deal with those who commit violence in terms that were unequivocally feminist and socialist: 'ultimately, the solution is for women to achieve economic and social equality in our society. Until then we can only work to limit the damage of that inequality. ${ }^{80}$ The CAW also cast violence against women as a class-based issue, and linked the bargaining the CAW had done for pay and employment

\footnotetext{
77 June 1992, Special One Day Council, Buzz Hargrove’s Speech, 27.

${ }^{78}$ Canadian Autoworkers, "Bargaining in Tough Times," document from the 2002 Collective Bargaining and Political Action Convention, 119.
} 
equity, as well as the advancement of women's equity programs within the union as all issues of importance to the working class.

The struggle for a pan-Canadian, universal child care program was a fight that saw feminists forge coalitions with trade unions. As Mahon outlines, Quebec unions fought for parental leave in the late 1970s, CUPW struck over maternity leave in 1981, and by the early 1990s paid maternity leave had become a common issue for unions to fight for. ${ }^{81}$ The CAW also championed child care, supporting the longstanding campaign for a national child care. The union negotiated a childcare program in The Big Three, but in the debate at Council around this program, the leadership noted that 'we cannot come close to meeting the commitments of our members, let alone the community when we talk about child care.' At Council, childcare was clearly seen as both a class issue and a women's issue, and there was support for the CAW's involvement in the broader campaign. ${ }^{82}$ By the mid-2000s, at a time when the feminist movement had been considerably weakened, the union had become a national advocate for a national childcare program, arguing that the needs of working class women, men, and families were not being met, and that a socialized childcare program was required ${ }^{83}$ The CAW also partnered with women's organizations around Canada to fight federal cuts to women's programs, noting that this was a 'blatant attack on women's equality. ${ }^{84}$

In 2009 the Council re-iterated its commitment to eradicating violence against women 'in our workplaces, in our communities and in society.' This recommendation, endorsed by the

\footnotetext{
${ }^{79}$ Ibid 118.

${ }^{80}$ April 1996 Council, President's report, 35. Emphasis mine.

${ }^{81}$ Rianne Mahon, "Child Care in Sweden and Canada: Policy \& Politics" Social Politics 4 no. 3 (January 1997): 402.

${ }^{82}$ August 1999 Council minutes, 67.

${ }^{83}$ April 2006 Council minutes; December 2006 Council minutes, 36.

${ }^{84}$ December 2006 Council minutes, 56.
} 
membership, prompted many male and female members of the union to come to the microphones to share stories of violence in the workplace against women, highlighting the work the union still had to do ${ }^{85}$ On the $20^{\text {th }}$ anniversary of the Montreal Massacre, the Council moved to reinforce the union's commitment to end violence against women. This commitment continued to include changes within the culture of the union, changes within the workplace, and changes in Canadian society: 'we must continue to press for decent work, affordable housing and strong social programs so that no one is forced to stay in an abusive relationship for financial reasons. ${ }^{96}$ As part of this commitment, the CAW donated $\$ 100000$ a year to women's shelters in Canada. ${ }^{87}$

The fight over the Long Gun Registry is one of the best examples of the Council's functioning both to pass information to the leadership - the number of CAW members who opposed the Registry - and to convince members of the appropriateness of the leaders' strategy. The CAW was an early and strong supporter of the Long Gun Registry in Canada, linking it to the union's commitment to end violence against women. ${ }^{88}$ Support for the Long Gun Registry originated with women in the union, particularly women on staff, who argued that most of the killings of women were done by guns, so it was a women's issue. The fight for the Registry was championed by Hargrove and especially Carol Phillips, but Hargrove 'never faced such a barrage of negative feedback in the union as he did on that issue. ${ }^{89}$ There was opposition to his stance voiced by (gun owning) representatives to Council, but many women members voiced their support for it. Hargrove was convinced that it was a 'logical extension of [the union's] social

\footnotetext{
${ }^{85}$ December 2007 Council minutes, 84 - 91.

${ }^{86}$ December 2009 Council minutes, 59 - 73.

${ }^{87}$ White, discussion.

${ }^{88}$ Ibid.

${ }^{89}$ Nash, discussion.
} 
work to say that guns should be registered. ${ }^{90}$ The union leadership saw the Registry as an important milestone in the struggle for women's equality. 'It started symbolizing the proverbial light at the end of the tunnel. If we allow [Prime Minister Stephen] Harper and his right-wing followers to this battle, we will throw Canadian women back to the Dark Ages. ${ }^{91}$

The CAW thus had a history of feminist, materialist, and class-based support for women's equality. While there was certainly an early commitment to women's equality and issues, The Montreal Massacre contributed to a sea change in the union, with the leadership, and eventually the rank-and-file, developing a deep commitment to elimination of violence against women in the workplace and in Canadian society. The CAW used its industrial strength, initially in auto but then elsewhere, to bargain for real gains for women and in the process became a leading voice for women's equality in the labour movement. The issues that the union championed were articulated as materialist, as important to women both within and without of the union, and as issues of importance to the broader working class.

\section{LGBTQ Rights \& Representation}

The CAW's leadership on equity issues within the Canadian labour movement or at least its private sector unions was perhaps clearest in the struggle for LGBTQ issues in the labour movement. The CAW, along with CUPE and PSAC, were among the first to incorporate sexual orientation as a protected ground for non-discrimination, as well as to make same sex benefits a priority in collective bargaining. ${ }^{92}$ In 1999 , the CAW called on 'All agreements must have a no discrimination clause that covers the following areas as a minimum: Age, sex, race,

${ }^{90}$ Buzz Hargrove, in discussion with the author, July 2013.

${ }^{91}$ December 2009 Council minutes, 59 - 73.

${ }^{92}$ Gerald Hunt and Jonathan Eaton, "We are Family: Labour Responds to Gay, Lesbian, Bisexual, and Transgender Workers," in Equity, Diversity, and Canadian Labour, eds. Gerald Hunt and David Rayside (Toronto: University of Toronto Press, 2007), 135. 
ancestry, place of origin, colour, ethnic origin, citizenship, creed, sexual orientation, record of offences, marital status, family status and handicap. ${ }^{93}$ The importance of making equity issues a bargaining priority - in all areas of equity - cannot be understated. By making equity a key bargaining issue, the union went beyond lip service and indicated its preparedness to use its significant bargaining clout to support change. By 1998, unionised workers at GM, Ford, Chrysler, and Northern Telecom obtained same-sex benefit coverage. ${ }^{94}$ The decision to begin by negotiating benefit coverage for same-sex couples at The Big Three followed the pattern established in negotiating gender equity. Once language was won in auto, it would be taken to locals in other sectors represented by the union. The union's presence and strength in the auto sector thus again helped it to further its equity agenda.

Organizing around LGBTQ issues within the CAW started in the legal department, where human rights were fought for using legal strategies. ${ }^{95}$

1994 saw the first major victory for LGBTQ CAW members. In this instance, it did not come from the auto sector but rather Northern Telecom, where the union first negotiated same sex spousal benefits, including survivor income benefits and pensions. ${ }^{96}$ Material support for LGBTQ members quickly expanded in to auto, however, with the CAW winning same sex spousal benefits at Chrysler. ${ }^{97}$ By 1996 same sex spousal benefits had made it to the CAW's master bargaining list, and the union was negotiating this language at all its workplaces. ${ }^{98} \mathrm{In}$

\footnotetext{
${ }^{93}$ Canadian Autoworkers, "Past Gains, Future Challenges. Mobilizing for the New Millennium" (document from the 1999 Constitutional Convention.) Emphasis Original.

${ }^{94}$ Ibid, 138.

${ }^{95}$ Lisa Kelly, in discussion with the author, September 2013.

${ }^{96}$ April 1994 Council, President's report, 5.

${ }^{97}$ April 1995 President's report, 13.

${ }^{98}$ Hargrove, Laying it on the Line, 133.
} 
1999 , the union committed to 'continual advancement for gay rights. ${ }^{99}$ In the early 2000 s the union developed language covering a wide range of issues of importance to the LGBTQ community, and placed these as central bargaining goals. These included recognition of samesex partnerships in the definition of spouse wherever it's laid out in their agreements; the incorporation of sexual orientation, same sex partnership status, and gender / sexual identity in non-discrimination and anti-harassment clauses; the addition of leave provisions, medical coverage, and return to work for trangendered workers; and coverage of same sex spouses in pension agreements. ${ }^{100}$

What differentiates the case of LGBTQ rights from other cases discussed in this chapter is that the union first seemed to negotiate for equity for the LGBTQ community before it made a clear commitment to changing the internal culture of the union. Support for same sex benefits was not uncontroversial within the union. For instance, at the December 1990 Council, members from Local 199 distributed a newsletter to the convention floor, which contained a letter to the editor attacking same sex benefits. A staff rep took to the microphone to rebuke the letter: 'everybody has the right I guess to express what they want and if they want to express it in writing that is fine, our periodicals are trade union periodicals and need not be the carriers of that kind of violent bullshit and I think it should be the policy of this union and I think it is a policy of this union to make sure that this does not happen.' ${ }^{101}$

There was often significant resistance to LGBTQ issues from rank-and-file members and many autoworkers opposed bargaining same sex spousal benefits. At one ratification meeting in local 222, the leadership faced intense homophobia from the rank-and-file, with members asking 'how

\footnotetext{
99 Canadian Autoworkers, "Past Gains, Future Challenges."

${ }^{100}$ Canadian Autoworkers, "Bargaining in Tough Times," 122.

${ }^{101}$ December 1990 Council minutes, 105.
} 
many faggots are there on that bargaining committee?'102 Such homophobia was generally countered by the national staff and the local leadership, at least when the latter was supportive. While the national union was strongly in favour of bargaining for LGBTQ issues, local leadership would sometimes refuse to do so. To tackle this problem, the national union made it clear that LGBTQ issues could not be taken off the bargaining table unless the local union had checked with the national executive board. On one occasion, described as a 'watershed moment,' Hargrove told a bargaining chair, who refused to bargain LGBTQ issues, 'if you can't do this then step aside as this is part of your job. ${ }^{103}$

As the CAW advanced a collective bargaining agenda for LGBTQ members, it also created space within the union specifically for these members. Before LGBTQ issues were recognized in full by the CAW, LGBTQ activists, who were not elected as Council delegates, would stand at the entrance of the Council and ensure that every delegate received copies of a specially created 'allies booklet,' designed to encourage CAW members to become LGBTQ allies. ${ }^{104}$ In this way LGBTQ members of the union began to organize both a space for themselves and to have their issues put on the union's agenda. The first noted instance of a space specifically for LGBTQ members was in 1995 when the Human Rights' Conference included 'discrimination faced by gays and lesbians' as a topic. ${ }^{105}$

The CAW was one of the first unions to create a space for LGBTQ brothers and sisters, and discuss openly the specific issues facing them. In 1996 the union continued its commitment to create space that is "safe and a place where they can discuss strategy to push their "our" issues

\footnotetext{
${ }^{102}$ Mike Shields, in discussion with the author, August 2013.

${ }^{103}$ Sue Carter, in discussion with the author, September 2013.

104 Ibid.

${ }^{105}$ December 1995 Council, national and area staff reps report, 31.
} 
in the union' for LGBTQ members with the creation of gay and lesbian caucuses in London, Vancouver, Toronto, and Windsor. ${ }^{106} 2000$ saw the first national Gay and Lesbian CAW conference, and 2001 saw the creation of an LGBTQ newsletter - "Pride in Print," regional LGBTQ workshops, the union participating in Toronto Pride, and regional LGBTQ conferences. 2002 saw PEL take up the issue of LGBTQ rights, with 'confronting homophobia' as a newly added PEL program. ${ }^{107}$ Currently, there is a pride conference every two years, and much like the women's advocate program, there is a pride activist program offered as part of PEL. ${ }^{108}$

LGBTQ CAW members were active organizing themselves within the union before they had official representation through a committee, and long before their struggle for equity was mainstreamed through the union leadership. A strategy used by LGBTQ activists within the CAW, designed to confront homophobia within the union, was the 'one in ten' strategy. At CLC conventions and CAW events, LGBTQ activists would stand at the doors of the convention, and hand one in every ten attendees a sticker, telling them "one in ten, you just won the lottery, one in ten workers are gay, you're gay for a day, be prepared: you will lose your friends, you will lose your family, and the support of the union." ${ }^{109}$ LGBTQ activists eventually changed tactics, noting that the 'one in ten' strategy was negative, and they had no interest in emphasizing negativities. Eventually these activists began to appeal to 'union instincts, working class instincts, and instincts around solidarity and dignity and respect. 110

The CAW also fought homophobia in society at large. It championed Marc Hall, a gay teenager who, in 2002, wanted to bring his boyfriend to his Catholic high school prom. The

${ }^{106}$ December 1996 Council, national and area staff reps report, 26.

${ }^{107}$ December 2002 Council, national and area staff reps report, 15.

${ }^{108}$ Ken Stuart, in discussion with the author, September 2013.

${ }^{109}$ Carter, discussion.

${ }^{110}$ Ibid. 
CAW linked Hall's case to fighting homophobia within the union. While the CAW had been working to promote LGBTQ rights before 2002, but its championing of Hall, and the national attention it brought the CAW, brought LGBTQ rights, to the forefront of equity issues within the union. The push to provide space and representation for the community within the union was closely linked to the case of Hall, which occurred in 2002, around the time when the CAW was making great internal advances. Hall was a gay teen attending a Catholic high school. When he submitted the name of his date - his boyfriend - to the school before prom, which they were required to do, the school denied him, claiming homosexuality was incompatible with Roman Catholic teaching.

Mike Shields, then president of Local 222, issued a press release in support of Hall. According to Shields, the 'press release caused some grumblings, you know, in the plant amongst some of my knuckle-draggers.' 111 Shields was approached by a member of Local 222 who told him that Hall was making a presentation at the Catholic School Board, and he agreed to attend the School Board meeting to provide moral support. By the end of the meeting it was clear that the trustees had no intention to allow Hall to speak, and Shields interrupted the meeting, demanding that Hall be allowed to make his case. ${ }^{112}$ Shields was escorted out of the room by police, and the entire event was captured by the local and national media. Through the media attention, Hargrove became aware of the case, discussed it the next morning with Shields, and took the case on. ${ }^{113}$ The organizing that took place within the CAW around pride issues, and making pride a priority within the union, saw a payoff with the Hall case. When the case hit, the groundwork for supporting Hall, Shields, and the union as a whole, was in place. Mike Shields

${ }^{111}$ Shields, discussion.

112 Ibid. 
had the support of the executive, which was important as he began to receive death threats and pushback from his own membership. ${ }^{114}$ Hargrove dedicated the CAW to Hall's struggle, ensuring that a member of the communication staff was permanently 'loaned' to Hall, to help with press conferences and public appearances during his struggle with the school board. ${ }^{115}$

The leadership quickly embraced the story of Hall, linking his fight for equality with the fight of LGBTQ members in the union. Hargrove particularly championed Hall, using his story to confront homophobia within the union. Hargrove noted to the membership that the support of Hall was 'the kind of actions that make this union different." 116

While the leadership of the union were strong supporters of the LGBTQ community, changing the culture of the membership proved to be more of a challenge. Shields noted that the Marc Hall story, and the embrace of Hall by the union leadership, opened a space within the CAW for more tolerant views. For example, Shields recalled that shortly after the Hall story broke, he was approached by one of his member in Local 222, who came to tell him that he "was gay, but he wasn't out, he had worked for GM for 25 years in Local 222, but had "never felt part of the union until now." 117 The CAW continued to be a leader within the labour movement, but at times faced great pushback from the rank-and-file. For example, in 2005, then president Ken Lewenza recommended that all locals support Bill C-38, in support of same sex marriage. The debate around this recommendation faced significant resistance from the floor of the Council, with members opposing it at the microphones: 'I believe in traditions. And I do not support same sex marriage. I won't support it today. I won't support it in the future. ... It is a hard thing

113 Ibid.

${ }^{114}$ Carter, discussion.

115 Kelly, discussion.

${ }^{116}$ Buzz Hargrove's Speech from the 2002 Collective Bargaining and Political Action Convention, 3.

${ }^{117}$ Shields, discussion. 
to sell to ordinary working people in this country. They just don't accept it. They believe in traditional values, morality, stability.' ${ }^{118}$ Lewenza urged members to support same sex marriage, seeing it as a class issue, arguing that 'it can divide working families against their union. It can divide their church against their community,' and calling on CAW members to show solidarity with LGBTQ workers, and support C-38. ${ }^{119}$

A year after this debate, Lewenza called 'on the Harper Government to respect the equality of gays and lesbians as passed by the last Parliament, not to proceed with another vote in the House on the issue of equal marriage.' ${ }^{120}$ This recommendation was passed by the Council without debate. The following year, 2007, marked the first time the Pride Caucus met at council. In 2010, The CAW held first ever one-week pride activist program, proving an opportunity for LGBTQ activists from across the country to strategize, plan and mobilize on issues that are relevant to our LGBTQ members as well as the rest of our membership. ${ }^{121}$ In 2010 Lewenza introduced a sweeping recommendation to Council surrounding LGBTQ rights, particularly the rights of LGBTQ youth:

"I recommend that local unions right across the country take the lead in talking to members about youth bullying, particularly the harassment and violence against LGBT youth. A string of tragic, high profile cases has demonstrated that this experience puts our youth at extra risk of suicide. Our union can make a difference in educating members about this issue. We can all benefit from a more accepting and compassionate world where we recognize our similarities and respect each others' differences." 122

There was extensive discussion of this recommendation from the council floor, virtually all in favour. This included statements from members on how all members of the union needed

118 April 2005 Council minutes, 9 - 10.

119 Ibid.

120 April 2006 Council minutes, 19.

${ }^{121}$ December 2010 Council, national and area staff reps report, 36.

${ }^{122}$ December 2010 Council minutes, 4. 
to better stand up for LGBTQ rights, both within the union and within Canadian society. This represented a rather rapid change: in a matter of a few years the union had gone from having a host of homophobic voices at the microphone to extensive support for wide-ranging LGBTQ issues.

Much like racial and gender equality in the CAW, equality for the LGBTQ community involved a number of incremental steps, designed to change the culture of the union, to improve conditions at the workplace, and to participate in changing Canadian society. These steps were driven, at first, by LGBTQ activists within the union, and then later championed by the union's leadership. At the workplace, the gains were materialist in nature - specifically surrounding same sex partner pension benefits. In the union, the case of Hall was symbolically linked to the struggles that LGBTQ members face, and this, in part, was used to challenge homophobia within the union. The CAW proved itself to be well ahead of most other Canadian unions, especially industrial unions, on LGBTQ issues, however, it lagged behind Canadian society as a whole.

\section{Class and Materialist Politics}

Much of the CAW's commitment to equity was rooted in class politics - including bargaining for better conditions for equity seeking members. The CAW also showed itself to be committed to broader class solidarities, using its position as a large union in a position of leadership in the Canadian labour movement, to advocate for equity outside of the confines of the workplace and the labour movement. This section will highlight some of the key initiatives that the CAW has undertaken to advance solidarity with workers who may not necessarily be organized, let alone by the CAW. While this work is not part of equity politics, it does serve to contextualize the relationship between class politics and equity within the union. 
In White's first report to the new Canadian union, he expressed concern over the cuts to pensions, rising unemployment, and taxes on 'middle income Canadians." ${ }^{123}$ Later, White critiqued the attack on universal health care in Canada. One of the responses to this report from a rank-and-file sister on the Convention floor is worth providing in full as it shows the importance of class politics within the CAW:

"But also on about everything that pertains to the poor and the middle class. We are being attacked by the right wing segment of our country and indeed the whole of North America is being attacked by the right wing. I think it is very important for us to move outside our local unions after we have done the work inside our local unions with this drive on the drug patent. ... What is really happening is that people like you and I that are of the strong middle class of Canada are being chipped away at, piece by piece by piece. They are breaking our union where they can, they are splitting, they are dividing, and conquering, and everything that they are doing is designed to destroy the middle class." 124

The CAW's class politics and rhetoric was based on White's vision of the union as a leader for the broader working class. As White saw it, 'because of the labour movement's strategic role in the economy, a vision of socialism had to be based on the working class. ${ }^{125}$ For example, the union's opposition to the GST articulated that the tax would disproportionally disadvantage the working class, but that the union needed to be careful to only oppose the GST in tandem with working class organizations:

'There are a lot of groups forming to oppose this tax and while we can have an affinity with certain groups, we should not support some others. For example: John Bulloch and the CFIB are leading a charge against this tax. This is the same John Bulloch who leads the charge for free trade, against minimum wage increases, against health and safety legislation, against union security, etc. ${ }^{, 126}$

The union also showed a commitment to the unemployed. In addition to advocating for

123 June 1985 Council, national and area staff reps report.

${ }^{124}$ September 1986 Council minutes.

${ }^{125}$ September 1989 Council, President's report, 17.

126 Ibid. 
job creation programs and strengthening unemployment insurance, the union set up programs to assist unemployed workers. For example, the NEB supported an effort by Local 40 to create a storefront in Toronto to offer ESL training to recent immigrants, to assist with immigration problems, to help workers apply for U.I., and to 'reach out to unemployed people, to offer assistance in their fight for justice, dignity, and jobs. This is an extension of our support for the Unemployed Help Centres set up through the local labour councils in many communities.' ${ }^{27}$ This was expanded into a call to organize people receiving UI benefits to plan demonstrations and occupy UI offices. ${ }^{128}$ The broader commitment to materialist class based politics saw the CAW work closely with anti-poverty groups and participate in numerous campaigns to raise the minimum wage, particularly in Ontario. ${ }^{129}$

In the late 2000 s the CAW turned its attention to the spread of precarious work. The union saw this as an important battle for the broader working class. To this end, the CAW set out a collective bargaining agenda to limit precarious work, as well as an agenda to pressure for legislative changes to limit this form of work. ${ }^{130}$ The commitment to fight precarious work was restated in 2009, where Lewenza urged all locals to tackle the issue of precarious work as 'the expansion of bad jobs threatens the security of our families, the fabric of our communities, and our hopes for a better economic future.'131

\section{Conclusions}

As Yates notes, there is an 'age-old problem that class-based identities and action sit

\footnotetext{
127 June 1992 Special Council, Buzz Hargrove’s Speech, 28.

${ }^{128}$ December 1993 Council minutes, 10.

${ }^{129}$ December 2007 Council, President's speech, 5.

${ }^{130}$ December 2009 Council, President's speech.

${ }^{131}$ December 2009 Council minutes, 20.
} 
uneasily with recognition of other bases of inequality, especially race and gender.' ${ }^{132}$ This chapter showed that the CAW "worked around" this problem by articulating equity issues as issues of class. Equity issues, for the CAW, were firmly rooted in class politics - politics of solidarity with the larger working class. Expressed in these ways, it was natural for the CAW to change their own internal culture, to bargain for equity based issues, and to attempt to act as an element of change in society at large. According to Briskin, 'the danger that the concerns of women and other equity-seeking groups inside unions will be marginalised has increased dramatically. In response, union equity strategies must proactively challenge the neo-liberal invocation of patriarchal and individualistic values for workplaces and households, and build solidarities across diversities.' ${ }^{133}$ By rooting equity issues in class politics, the CAW strove to challenge neoliberal doctrine and build a culture of working class solidarity across a multitude of diversities.

The CAW was forced to grapple with equity issues as a response of the organizing the union undertook as a reaction to plant closures. As the union organized new workplaces, especially those outside those in the auto sector, it became more heterogeneous - less 'white and male'. New identities took shape within the union, and they sought representation. Many of these issues manifested at council - first as informal caucuses or campaigns, and later as formal, recognized groups. In this way, part of the class identity of the CAW was driven by the external economic environment; the union was forced to adapt to the changing economy by organizing, and this, in turn, shaped the identity of the union.

\footnotetext{
${ }^{132}$ Charlotte A. B. Yates, "The Revival of Industrial Unions In Canada: The Extension and Adaptation of Industrial Union Practices to the New Economy" in Trade Unions in Renewal: A Comparative Study, eds. Peter Fairbrother \& Charlotte A. B. Yates ( London: Routledge, 2003), 239.

${ }^{133}$ Linda Briskin, "The equity project in Canadian unions," 32.
} 
The CAW saw equity as a collective issue and a class issue. The union saw moving in a progressive direction as a form of broader working class solidarity. For the CAW, divisions along identity lines were artificial, and used by employers to divide the working class:

'our philosophy is, everybody ought to be treated equally regardless of their race, religion, colour, or creed, and that is the philosophy of the Labour movement and some of these people who are advocating individual human rights are advocating an attack on the Labour movement and an attack on those things that we stand for and the employers will encourage some of that.' 134

To this end, the CAW saw equity as linked to class questions, and sought to use its significant industrial power to bargain for better working conditions for all members of the working class that the union represented. Further, as a strong voice in the Canadian labour movement, with a not insignificant amount of political clout, the CAW sought to influence Canadian society writ large.

Equity in the CAW is a complex issue. In most cases, equity was championed by the leadership, and often staff, of the union. Using symbolic bricolage - with the cases of Apartheid, the Montreal Massacre, and Marc Hall - the union tied issues of societal importance to the struggle for equity within the CAW. This allowed the leadership to open a space to change the culture of the union. The leadership often championed a dual struggle, for equity within the union as well as without. Meaningful representation, in the form of caucuses, committees, and conferences, were established within the union in an attempt to give equity seeking groups a space to organize on their own. As Briskin argues,'separate organising [for equity seekers] may offer a critical space in which to politicise rank and file membership ... For such organising to be successful, however, both autonomy and integration measures are necessary. ${ }^{135}$ Certainly the

\footnotetext{
${ }^{134}$ Bob White, in a speech to Council, March 1986 Council Minutes.

${ }^{135}$ Briskin, "The equity project in Canadian unions," 37.
} 
caucuses, committees, and conferences within the CAW provided both the aforementioned autonomy and integration for equity seeking groups: autonomy to pursue policies and agendas specific to their group, and integration into the larger body of the union. The equity seeking groups became active participants within the CAW, and contributing to the internal politics of the union, the collective bargaining agenda, and to the CAW's attempts to act as a leader for the Canadian working class. Through the industrial power the union wielded, significant material gains at the workplace were negotiated for equity seeking groups.

These often initially occurred in the automotive sector, and would then branch out to other sectors of the union. Indeed, this once again highlights the importance of the strength of the automotive sector to the CAW: the union was able to secure equity language due to the strength it had at The Big Three. Ironically, it was the decline of auto that led the CAW to expand, which, in turn, led to the CAW having to bargain for equity language within the automotive industry. 
Chapter Five: The CAW, elections, and Extra-Parliamentary Politics ${ }^{1}$

\section{Introduction}

The relationship between organized labour in Canada and the New Democratic Party has always been a complex one. ${ }^{2}$ The CAW's relationship to the party and to electoral politics in general were driven by two major factors. First, the CAW looked to defend union member's jobs by seeking electoral redress against the impact of free trade, plant closures, and deindustrialization. Second, the CAW looked for a way to electorally advance the leadership's social democratic vision for Canadian society. Thus while the CAW and the NDP had a shared ideological commitment to social democracy, the CAW also saw the NDP as an important ally in the battle to protect CAW workplaces and jobs.

The CAW Council played an important role in the development of the union's electoral strategy. Indeed, it was in the development of the union's electoral strategy where the Council most acted as Sabel predicted, passing information upward and downward, working to shape rank-and-file expectations, and convincing the members of the appropriateness of the leadership's strategy. While the Council acted as a forum where the political positions of the leadership could be modified, more frequently the Council functioned as a place where the political positions of the leadership were disseminated through the activists at Council to the

\footnotetext{
${ }^{1}$ As the introduction to this dissertation has outlined, this dissertation has focussed on the CAW in Englishspeaking Canada, it is worth reminding the reader of that for this chapter. The TCA was politically independent of the CAW, and would frequently support the PQ and BQ in elections, even when the CAW was supporting the NDP or endorsing strategic voting.

${ }^{2}$ The lengthy history of the interactions between organized labour and the NDP has been covered by in great detail by a number of Canadian scholars. A discussion of the CCF, the early NDP, and organized labour can be found in Irving Abella, Nationalism, communism, and Canadian labour, 1973. Gad Horowitz's seminal work, Canadian Labour in Politics, 1968, provides an excellent historical overview and a theoretical look at how liberalism and socialism have influenced Canadian labour in politics. Norman Penner covered the history of social democratic parties in From Protest to Power, while William Carroll \& R. S. Ratner's edited volume Challenges and Perils discusses provincial social democratic parties and organized labour, and Larry Savage's "Contemporary party-union relations in Canada," 2010, provides an excellent overview of the current state of unions and electoral
} 
broader union's activist base.

Initially the CAW expressed strong support for the NDP but various factors contributed to the fraying of the relationship between the union and the party, not in the least a perception that the NDP did not do enough to fight free trade. In the late 1980s and early 1990 s, the CAW moved to become a 'left critic' of the party - still supporting the NDP electorally, but critical of the party's move towards the political centre. This 'left criticism' was born from the NDP's perceived failure to fight free trade and from an ideological rupture with the NDP in Ontario. While the CAW had initially been hopeful that an NDP government in the province with the most CAW members would lead to policies favourable to the union, the Rae government disappointed its expectations. As a result, from the late 1990s onward the union became a supporter of strategic voting - supporting whichever party could defeat conservative parties.

Its strategic voting strategy also reflected its concern to support the long-term viability of the automotive companies, which became a central part of its strategy in the neoliberal era protect members' jobs from plant closures in whatever way possible. The union moved from claiming that the Liberals and Conservatives were indistinguishable from one another ${ }^{3}$ to one where they supported voting for the Liberal party in ridings where the NDP could not win against the Conservatives. ${ }^{4}$ The political rationale for this had come full circle - the union believed that strategically voting against the Conservatives was the best strategy to keep CAW workplaces in manufacturing open, thus securing jobs for members.

The CAW's electoral strategies were thus largely driven by the changes in manufacturing

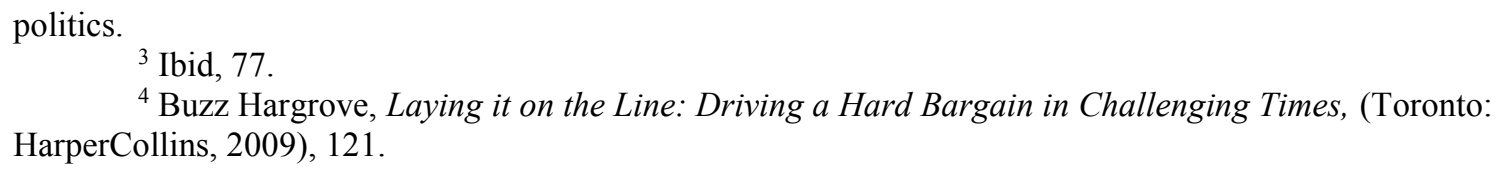


in North America. As the auto sector had a privileged position within the CAW, protection of the auto sector - and jobs in that sector - as paramount to the union's political action. The shift to strategic voting was in no small part driven by the idea that when in power the Liberals were better allies to manufacturing capital than the Conservatives.

To be sure, as chapter 3 showed, the CAW was capable of expanding its definition of political action to a scope well beyond electoral politics. The history of the union is full of plant occupations, sit-down strikes, the occasional wild-cat strike, and participation with broader social movements. As time went on, however, the reliance on extra-parliamentary political action waned and the union put more and more emphasis on elections as a way to solve problems. 1985 - 1988: CAW Supports the NDP

The Canadian UAW played a role in the formation of the NDP and was a supporter of the party from its foundation. Thus most of its political action focussed on building electoral supporting for the party and encouraging union members to join. The CAW's relationship with the NDP gained a new meaning in the 1980s as the NDP emerged as an opponent of free trade. As was argued in chapter three, opposition to free trade was a major issue for the CAW, so the relationship between the CAW and the NDP was strengthened when the party became vocally opposed to free trade. In the shared opposition to free trade, the CAW saw the NDP as a key ally to stop deindustrialization and plant closures. The union's commitment to the NDP was also connected to its commitment to a broader vision of social justice. It saw the NDP as the vehicle to a more just society for its members and for the broader working class: 'in recognition for the need for independent political action, Canadian working people have joined others with similar aspirations to build a political party that speaks to our needs and goals. This party is the New 
Democratic Party of Canada. ${ }^{5}$

One of the earliest CAW Councils dealt with the issue of electoral politics, specifically the Ontario election. The 1985 provincial election was tightly contested between all three parties, and White called for the union to support the NDP to 'at least become the official opposition.' ${ }^{6}$ Then ONDP party leader, Bob Rae, was an invited to address CAW delegates. White's call to put 'maximum effort' into supporting the NDP was accepted by the Council delegates, with numerous members declaring their support for the NDP. Council agreed to send financial support to candidates and riding associations while union staff urged locals to affiliate with the party. ${ }^{7}$ Nine CAW members ran as candidates in the election and twenty three union members were released from work to work on the NDP campaign. ${ }^{8}$

Two days after the election, which resulted in a minority Conservative government, Rae invited White to attend a small group meeting to discuss the direction the NDP should take. ${ }^{9}$ At this point, the union was treated as a close strategic ally of the party. The Liberals, led by David Peterson, and the ONDP ultimately agreed on an accord whereby the NDP would back a Liberal minority government during confidence votes for two years in exchange for the government's introduction of specific NDP public policy planks. The CAW fully supported the Peterson-Rae $\operatorname{accord}^{10}$ as a way to advance public policy directly beneficial to the union and to the broader Canadian working class.

The CAW's support for the NDP during the 1985 election was not unproblematic. For example, at least one member of the union who ran as an ONDP candidate in Windsor was asked

\footnotetext{
${ }^{5}$ Canadian Autoworkers, "Unions and Politics," document from the 1991 Constitutional Convention.

${ }^{6}$ March 1985 Council, President's Report, 12.

${ }^{7}$ March 1985 Council minutes, 10- 15; March 1985 Council, national and area staff reps report, 109.

${ }^{8}$ June 1985 Council, national and area staff reps report, 1.

9 June 1985 Council, President's report, 11.
} 
to 'hide' the fact that he was a labour candidate as the party saw trade union membership as an electoral liability. ${ }^{11}$ Yet members of the CAW Political Action department promised to take the 'concerns back to the caucus of the ONDP and the Provincial Council when we have our next meeting, ${ }^{12}$ which suggests that at this point there was a two-way dialogue between the party and the union. Through the mid-1980s, the CAW actively supported the party. The Political Action department encouraged locals to affiliate to the NDP and called on them to start Political Education Committees whose main purpose was to convince members to vote NDP. ${ }^{13} \mathrm{Ed}$ Broadbent, leader of the federal NDP, was an invited speaker at the December 1985 council. Aware that the Peterson-Rae Accord would expire in 1987, the union focussed political energy on the election campaign in 1987. One of the main forms of support for the NDP was a dues deduction of \$1 per member in Ontario that raised \$125000 for the party. ${ }^{14}$ The union's 1986 political education conference, which was centred on the NDP, included workshops for electionday organizing, canvassing for the NDP, information on The Accord, and raising funds for the party. $^{15}$

As detailed in chapter three, the 1980s saw a wave of plant closures in North America, and these closures, and the ensuing job losses, became the union's primary political concern. It was at this juncture that the belief in the NDP as the primary agent to fight plant closures and to protect jobs was at its strongest. When the sale of a De Havilland plant was announced in 1985, a delegate to the council suggested the plant closure could have been avoided if more CAW members voted NDP:

\footnotetext{
${ }^{10}$ Bob White, Hard Bargains. My Life on the Line (Toronto: McClelland and Stewart, 1987), 364.

${ }^{11}$ June 1985 Council minutes, 31.

12 Ibid, 32.

${ }^{13}$ December 1985 Council, national and area staff reps report, 4 - 6.

${ }^{14}$ September 1986 Council minutes, 4.
} 
'I think [the plant closure] emphasizes to me the necessity for political education. All of us should go home and really work to politically educate our members and all our fellow workers. How many of our members at De Havilland voted Conservative? I think probably quite a few and for me this present situation should being home to all of us how necessary it is to vote for the NDP. ${ }^{\text {, }} 6$

Another member noted that plant closures are 'not something you can address at the bargaining table - it needs a political solution.' This same member urged CAW members to 'get out there with the New Democrats and start working in those associations now to build up the strength ... if we don't do it now, there will be a lot more sad stories at this microphone. ${ }^{17}$

\section{8 -1993: From Free Trade to the Social Contract}

Heading into the 1988 federal election, the CAW had two major political projects. The first was opposition to the free trade agreement. The second was strengthening bonds with the NDP. Yet the 1988 election severely challenged the relationship between the party and the union, as the union came to see the NDP as no longer the sole political vehicle to meaningfully advance its policy agenda. While other issues would fracture the relationship between the CAW and the NDP, this election was certainly the first major break.

The 1988 federal election was largely fought on a single issue - the proposed free trade deal between the United States and Canada. The Progressive Conservatives supported the deal while the Liberals and the federal NDP opposed it. The CAW, along with the majority of organized labour in Canada, saw this election as one of the most important political fights facing the labour movement. White identified Free Trade as the "most dominant political issue facing Canada.' Accordingly, he encouraged CAW members to 'maximize our efforts in support of the

${ }^{15}$ September 1986 Council, national and area staff reps report, 1.

${ }^{16}$ December 1985 Council minutes, 21.

${ }^{17}$ November 1987 Council minutes, 43. 
NDP as never before.' ${ }^{18}$ As the election drew closer, the CAW continued to ramp up its support of the federal NDP and White hoped that the years of political action within the union, heavily skewed towards supporting the NDP, would 'translate into thousands of votes in support of the NDP.' ${ }^{19}$ The Political Action department was consumed with the federal election, and the department's report to the October Council focused on co-ordinating CAW, CLC, and NDP election strategy. ${ }^{20}$

Support for the NDP in the 1988 election was debated at Council but the delegates were overwhelmingly supportive of the recommendation to support the party with dozens of Council members speaking at the microphones in favour of the party. Throughout the entire discussion, only one speaker - Joe Flexer, a constant socialist voice within the union - expressed any hesitancy at supporting the NDP: 'I was very dismayed this morning to read on the front page of the Toronto Star where it was said by the Star that Broadbent did not even mention the Free Trade issue in his opening remarks as to the election. ${ }^{, 21}$ Virtually all of the reports from the staff and White, as well as the speeches from the floor of the Council, expressed a deep concern that Canada would become a colony of the United States if free trade were to pass. In this way, the debate was perhaps more informed by the legacy of left nationalism in the CAW than by the union's socialist left.

The election became a turning point in the relationship between the CAW and the NDP. The Canadian labour movement concluded that the Conservative's victory and the resulting conclusion of the free trade deal were at least partially the fault of the NDP. While the

\footnotetext{
${ }^{18}$ March1988 Council, President's report, 1 - 4.

${ }^{19}$ October 1988 Council, President's report, 5.

${ }^{20}$ October 1988 Council, national and area staff reps report, 1.

${ }^{21}$ October 1988 Council minutes, 18.
} 
Progressive Conservatives and Liberals had campaigned exclusively on the issue of free trade, ignoring the advice of virtually all unions and union federations the NDP, campaigned on a multitude of issues, of which free trade was but one. Thus organized labour, especially the CAW, felt that the NDP had not paid enough attention to the single most important issue facing Canadian workers.

White's condemnation of the NDP was swift:

'To say that I was troubled by this campaign, would be a gross understatement. ... The fact that the NDP didn't mention free trade in their initial election kick-off press statement, while I couldn't believe it ... I am sure, most of you know by now that I felt so strongly about what happened to the NDP in this election, I decided we couldn't let it pass without a major debate about what happened and where we are going. I felt an obligation to do this not only because as an organization, we in the CAW had committed so much in time and effort around the trade issue, but also because there was enormous disappointment throughout the labour movement and Party activists; not that we had lost, but how it happened. ${ }^{22}$

White's statements to the Council followed a seven page letter, written to the party executive, entitled "Lost Opportunities." The letter called for a full debate within the party on the direction of the NDP. In it, White highlighted the frustration that labour activists felt around the fact that the party never came to grips with the importance of free trade. White openly criticized the party for accepting support from labour while ignoring the labour movement's ideas and policy recommendations. For White, the party had not failed by accident, but by design.

The Council delegates - including some who had previous defended the party at the microphones - were equally scathing in their indictment of the NDP. The party was criticized for distancing itself from the labour movement, for refusing to take labour's policies seriously, and

\footnotetext{
${ }^{22}$ February 1988 Council, President's report, 5 - 6.
} 
for thinking labour is part of the party for 'bucks and tokenism. ${ }^{23}$ One delegate suggested that the NDP had failed to take a class analysis seriously, saying that the NDP was afraid to stand with unions for fear of being connected with "big labour," but arguing that the party needed to understand that 'there are working people and there are owners and the government stands at the side of the owners and that is the issue.'24

In 1989, White once again blasted the party for refusing to let labour 'fight a fundamental issue on our terms - the terrain of left nationalism. ${ }^{, 25}$ Nevertheless, at the same time, the union's political action department was involved in a major drive to get CAW members to join the Ontario NDP on the eve of the 1990 provincial election ${ }^{26}$ Leading up to the election, White urged CAW members to support the ONDP, and the political action department ran a membership drive for the party in Ontario. ${ }^{27}$ When the issue of supporting the Ontario NDP was brought to Council, it passed without any debate. ${ }^{28}$

The 1990 Ontario election saw the NDP come to power with a majority government for the first time in the history of the province. The NDP's victory was unexpected, however, and the party was ill-prepared to take power. ${ }^{29}$ Nevertheless, many social movements, anti-poverty groups, and trade unions felt that the NDP's victory provided their chance to change Ontario. For example, the Alliance for Employment Equity, supported by many unions including the CAW,

${ }^{23}$ February 1989 Council minutes, $57-61$.

${ }^{24}$ Ibid, 57.

${ }^{25}$ June 1989 Council, President's report, 16.

${ }^{26}$ June 1989 Council, national and area staff reps report, 1.

${ }^{27}$ August 1990 Council, President's report; August 1990 Council, national and area staff reps report, 15.

${ }^{28}$ August 1990 Council minutes.

${ }^{29}$ As the Bob Rae government was the first NDP government elected in Ontario (and outside of Western Canada), it generated a great deal of academic interest. As a starting point, Thomas Walkom's Rae Days, 1994, argues that Rae alienated the base of the NDP by attempting to appeal to a broad section of class interests. George Ehring \& Wayne Roberts, in Giving Away A Miracle, 1993, argue that the reformist roots of social democracy led to the NDP's betrayal of organized labour. 
'came into being at a time when Ontario was going through a period of dramatic political change under the NDP. Conditions seemed appropriate for significant state-civil society collaboration for progressive policy change. ... The AEE seized the moment to achieve what could be won., ${ }^{30}$ Employment equity legislation was eventually passed by the NDP, highlighting the relative importance to the CAW of electing social democratic parties that had a willingness to support projects which would benefit the working class. A record number of MPPs were from the labour movement or other social movements, and many groups, including the CAW, saw Rae's government as a vindication of years supporting the NDP.

The CAW was perhaps more cautious than other trade unions in its approach to the Rae government. Still suspicious of the party as a result of the 1988 federal election, the union was pleased with the NDP win but saw the need for the union to act as a 'left critic' of the Party - i.e. acting in a capacity to help pull the government to the Left: 'While the labour movement helped elect this government, we must also understand that the government ... will at times, not move fast on an issue, or legislate an issue as clearly as we would like, and there will be times when criticism will be absolutely necessary.' ${ }^{31}$ To this end, the union organized a demonstration with the OFL in March of 1991 to 'show our disgust with the Tory business agenda, the economic havoc it is causing workers and to let Bob Rae and the NDP government know we need plant closure legislation. ${ }^{32}$

Discussion of the Ontario NDP government reflected the spectrum of views on the left within the CAW, including everything from unwavering support by social democrats, to a

${ }^{30}$ Abigail B Bakan \& Audrey Kobayashi, “"The Sky Didn't Fall': Organizing to Combat Racism in the Workplace - The Case of the Alliance for Employment Equity," in Race, Racialization, and Antiracism in Canada and Beyond, eds. Genevieve Fuji Johnson \& Randy Enomoto, (Toronto: UTP, 2007), 72.

${ }^{31}$ December 1990 Council minutes, 17. Bob White speaking.

${ }^{32}$ April 1991 Council, national and area staff reps report. 
critical support, to a complete dismissal of the party for failing to be socialist. Not surprisingly Council delegates expressed a range of mixed reactions to the NDP government. Some criticized the government for not having an 'offensive fore-looking vision' that was clearly socialist, while others suggested it was not fair to criticize the party at all, as they had not been in power before, and any early government would have problems. One sister went so far as to criticize the council for criticizing the NDP: 'we have been in opposition so long that we are having difficulty adjusting to having a government that is our friend. We are used to criticizing the government, we are used to harp and belly ache about everything. ${ }^{33}$

During the early years of the Rae government's mandate, the CAW continued to support it while also criticizing it when it felt this was necessary. The union was concerned that if the labour movement did not constantly put pressure on the party in government, the NDP would become 'too cautious.' 34 The CAW was very pleased with the sweeping changes made to the Ontario Labour Relations Act by the Rae government, seeing them as a victory for both union members and the broader working class. ${ }^{35}$ In Buzz Hargrove's first report to the Council as CAW national president, he seemed to summarize the union's position on the NDP: 'this should show to us the importance of electing social democratic governments. We will have disagreements with them and that's healthy, but we must always remember the alternative. ${ }^{36}$

The deepening economic crisis facing the Rae government ultimately severely strained the union's relationship with the provincial party. After trying, and failing, to use Keynesian measures to deal with economic crisis, the Rae government introduced The Social Contract Act

\footnotetext{
33 April 1991 Council minutes, 20 - 24.

${ }^{34}$ April 1992 Council, President's report, 22.

${ }^{35}$ April 1992 Council minutes.

${ }^{36}$ August 1992 Council, President's report, 44.
} 
in an attempt to deal with the deficit in province. The Act marked a major shift within the Ontario NDP: the party, which had been slowly tacking right, now seemed to be embracing the logics of neoliberalism and completely abandoning Keynesian measures. The Act called for the opening up of previously negotiated public sector collective agreements to implement a wage freeze, which would be taken in the form of unpaid days off of work for public servants - later to enter the rhetoric of Canadian politics as 'Rae Days'. ${ }^{37}$ Hargrove characterized the proposed $A c t$ as 'not a social contract: it was an abuse of power by an employer.' ${ }^{38}$ The CAW, having already criticized the proposed Act felt further betrayed as the day before Rae introduced the Act, he held a meeting with leaders of all the private sector unions in Ontario, except Hargrove. ${ }^{39}$

While no CAW members were affected by the Act, the union saw the legislation for what it was - an attack on free collective bargaining. While all other private sector unions stood behind the NDP and supported the Act, the CAW showed great solidarity with public sector workers and fully opposed the Social Contract Act. ${ }^{40}$ Hargrove took exception to the other private sector unions; refusal to condemn the Act, suggesting that these unions did not have any sense of solidarity and fundamentally misunderstood the nature of public sector work when these unions 'thought public sector unions led cozy, sheltered lives. Public sector workers were seen by some private sector leaders as fat cats who had been able to avoid major layoffs and wage

${ }^{37}$ The political economy of the Social Contract Act, as well as an extensive class-based analysis of the Bob Rae government, and a historical overview of how the Ontario NDP came to power, and the labour-centred legislation it introduced, can be found in Chapter 8 of Panitch \& Swartz, From Consent To Coercion, 2003.

${ }^{38}$ Buzz Hargrove, in discussion with the author, July 2013.

${ }^{39}$ Buzz Hargrove, Labour of Love: The Fight to Create a More Humane Canada, (Toronto: McFarlane Walter \& Ross, 1998), 158.

${ }^{40}$ The immediate fallout from the Social Contract Act saw all private sector unions, save the CAW, support the NDP and the Act. Many saw the NDP as the only viable electoral alternative, even if the Act was functionally nothing different than what the other bourgeois parties had instituted in the past. Many private sector unions also held a great deal of resentment towards public sector workers, thinking that while the private sector had been decimated in the wake of Free Trade and neoliberal restructuring, that public sector jobs remained mostly intact. Put crudely, most non-CAW private sector unions held a position of 'we've had ours, now it's time for you to get 
concessions already forced on private sector unions. ${ }^{41}$

The debate at Council over the NDP and the Social Contract Act reveals that much of the political debate in the CAW during the early 1990s echoed many earlier debates within the Canadian UAW- a struggle between the left-leaning, socialist, elements of the union with the more centrist social democrats. Ultimately, the actions of the NDP government in Ontario however resulted in a great deal of anger and disappointment and ultimately contributed to the union's distancing itself from the party. The NDP had failed to articulate an effective alternative to neoliberal logics when faced with an economic crisis. The NDP had moved rightward from its traditional social democratic values and was adopting neoliberal policies which were indistinguishable from those that would have been enacted by the traditional bourgeois parties in Canada.

In the first Council meeting after its passage, the Act was the centrepiece of discussion; Hargrove described it as 'the most draconian piece of legislation affecting working people in the history of the province. ${ }^{42}$ Hargrove went on to outline a response to the Act that:

'must include withdrawing our support from the NDP Government of Ontario and, to limit support for the New Democratic Party of Ontario to the very minimum levels that allows us, by constitution, to maintain our affiliation at both the local and national level. This means we will not, at this point, withdraw totally from the party we helped to build, but will stay and fight for change within the party to ensure that never again, will the rights of organized workers be so callously set aside, least of all by a government we supported. ${ }^{43}$

Hargrove was laying out a path to change the NDP from within - an attempt to have labour move the NDP back to the left and to make it a party much more supportive of the labour movement.

\footnotetext{
yours.'

${ }^{41}$ Hargrove, Labour of Love, 157.

42 August 1993 Council, President's report, 1.

${ }^{43}$ Ibid, 12. Emphasis original.
} 
This would subsequently become one of the union's main strategies. Many members did see the Act as the ultimate betrayal by a social democratic party and supported the leadership's recommendations, in some cases, going so far as to suggest that the leadership had not gone far enough. There were calls for the CAW to completely disaffiliate from the NDP, including the federal party. ${ }^{44}$ Some suggested that the ultimate betrayal came from CAW members who were elected to government and subsequently voted for the $A c t .{ }^{45}$

The 1995 Ontario election proved to be the first real test of the CAW's new electoral direction. In the wake of the Social Contract Act the NDP was running a distant third in the polls, and had no reasonable chance of re-election. As we have seen, the leadership argued that the union should punish the NDP by refusing to support any candidate who voted in favour of the Act. The union also decided to conduct an 'independent campaign among members and the public' to place issues

'important to working people on the agenda. We will insist that all candidates declare their commitment to the principles of labour, to national medicare, social programs, public housing, child care, public education, with more working class input. We will campaign to inform our members of the positions of the candidates and their political parties, and let them decide who best represents their interests. ${ }^{46}$

Hargrove however became increasingly convinced that the biggest political issue for the CAW was to get rid of the Harris government, and that the best way to do this was through strategic voting. $^{47}$

This recommendation proved divisive. Some on the left rejected this, calling on the CAW to completely abandon the NDP: 'Sooner or later, all of us are going to face up to the fact

\footnotetext{
44 August 1993 Council minutes, 12.

45 Ibid, 9 .

461994 Constitutional Convention, President's address, 14. In many ways, this speech represents the first
} 
that social democratic parties -- and especially social democratic governments -- around the world are all moving to the right and there's no evidence that any of them are about to change course. ${ }^{48}$ For one delegate, this meant a turn to strategic voting: 'I support the position of the CAW as a trade unionist, but as a person I cannot stand by and not work for an NDP candidate when I hear the policies and programs of Lyn McLeod or Mike Harris.' ${ }^{49}$ Many delegates to the council however indicated that they would support the NDP in the upcoming election because there was no viable alternative to the NDP. ${ }^{50}$ Some delegates went even further than this, suggesting that the union needed to forgive Rae and provide complete support to the NDP. Much of this unwavering support for Rae came from Local 112, where the Rae government bought $49 \%$ of de Havilland Aircraft, preventing a plant closure and saving 2000 jobs. ${ }^{51}$ For these delegates, 'Rae had simply dealt with the public sector workers as their employer ... he made a choice regarding minimal cutbacks or massive layoffs. ${ }^{52}$

During the early 1990s the CAW's attention was split between the Ontario government and the federal political scene. At the same time as the union was condemning the Ontario NDP, it was voicing its support for the NDP in the upcoming federal election. The union was apprehensive about discussions to expand the Free Trade agreement to include Mexico - the agreement that would later become NAFTA - and saw this as the primary electoral issue at the federal level. Arguing that an expanded free trade agreement would lead to more plant closures and job losses, the union mobilized to challenge the proposed agreement. White argued that the

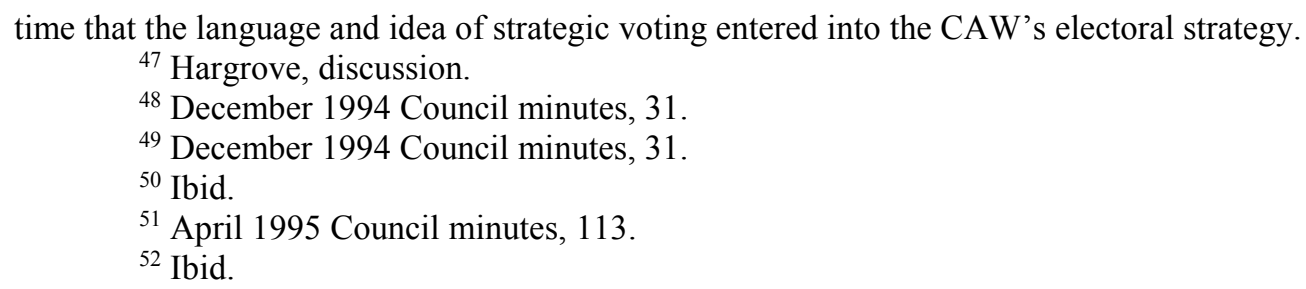


1993 federal election would be 'the most important election in the history of Confederation. ... If NAFTA is passed and the Tories, Liberals or Reform Party are elected, we have entrenched in an irreversible way, the corporate agenda in Canada. ${ }^{, 53}$ Despite the failure of the NDP to fully campaign against free trade in 1988, the CAW committed to full-fledged support of the NDP during the 1993 federal election. Council delegates suggested that 'The NDP ... has a clear position on the free trade and if we manage to focus this election around the issue of the free trade, they are certainly good perspectives. ${ }^{, 54}$ After a few short years of being sharply critical of the NDP, the union seemed prepared to move back into the federal party's fold. For some, but not all, delegates, the position of being a 'left critic' of the NDP had faded as well: 'we will get a hell of a lot more from an NDP government than we would ever get - and history tells us that from a Conservative government or from a Liberal government. And you certainly aren't going to get anything from the Reform Party! So our friend in politics is the NDP. ${ }^{55}$

Driven by the desire to defeat expanded free trade through NAFTA, the CAW endorsed the federal NDP. This was seemingly at odds with its position on the provincial wing of the party, something Hargrove recognized: 'if we were to get our traditional vote around twenty per cent, we would more than likely hold the balance of power in a minority government. This must be our goal, and I acknowledge that this will not be easy, given our problems with the NDP Government of Ontario. ${ }^{56}$ At the August 1993 Council there was a lengthy debate by members on the direction of the CAW's involvement with the NDP, which informed both by the Social Contract Act in Ontario and the upcoming federal election. This debate revealed, again, the wide

\footnotetext{
${ }^{53}$ December 1992 Council, President's report, 31.

54 August 1992 Council minutes, 49.

55 December 1992 Council minutes, 18.

56 August 1993 Council, President's report, 24.
} 
range of left-leaning views within the Council.

The recommendations from Hargrove sketched out what would be the general framework for the forgoing political action within the CAW - a critical support of the NDP, with the goal of moving the NDP to the left. The plan to achieve this, generally, was a 'change the NDP from within' strategy: having CAW members who were in the NDP attempt to influence a leftward shift in the part.

'While we continue to urge all CAW locals to stay within the party to work towards eventually making the party and ultimately an NDP government accountable to its membership and policies, we particularly emphasize the following steps to counter the disheartening actions of the Ontario NDP government and as a strategy to change future outcomes:

1. The CAW deny all support in the next election to any member of the NDP caucus who voted for the repressive legislation which has so cynically and shameless been labelled a social contract.

2. Ontario CAW locals minimize their contributions to the Ontario party to the level needed for membership, the remaining funds to be diverted to the federal NDP and towards the activities discussed below.

3. We make a serious and major commitment to building the kind of base within our union, the labour movement, and with the social movements that can mobilize and sustain pressures on any government that takes our needs and demands seriously.' 57

Many Council delegates were staunchly opposed to these recommendations and any criticism of the NDP. In making their case, they highlighted previous progressive gains for the working class such as pay equity legislation, changes to organizing laws through Bill 40, and the introduction of anti-scab legislation. ${ }^{58}$ Some members refused to see the Act as a betrayal of trade union values, and suggested that the CAW had a duty to support the NDP no matter what: 'I know many of you know many of these people personally and have worked with them over the years and I don't believe that they're traitors to working people, whether or not we agree with the

\footnotetext{
${ }^{57}$ August 1993 Council minutes, 26.
} 
social contract legislation. ${ }^{59}$ Many members were opposed to distancing the union from the NDP arguing that a Progressive Conservative or Liberal government would be worse for working people. ${ }^{60}$ One speaker noted the proposed strategy's inconsistency between moving away from the Ontario NDP and supporting the federal NDP ${ }^{61}$.

After lengthy debate, the Council endorsed the position of the union leadership: a step away from the NDP, but still participation in the party but subsequent Council meetings witnessed vigorous debate on the NDP while the leadership reiterated its strategy of 'rebuilding the party from within' strategy. The party's failures were outlined, but the union saw the solution as engaging in an effort to rebuild a social democratic party:

'the labour movement stands to lose all credibility with our membership if we show blind loyalty to NDP provincial governments who attack collective agreements, social programs, and move to the right on economic issues. We need to start thinking seriously about what the social democratic movement in Canada will represent as we move into the next century. This requires, at a minimum, a policy review.' 62

At the same time Hargrove's December 1993 report planted the seeds for a shift in the union's electoral orientation - strategic voting. Hargrove's report questioned the 'appropriateness' of the CAW financial support to the NDP and inviting only representatives of the NDP to CAW conventions and events and asked if the union should 'consider endorsing progressive candidates from different parties rather than endorsing one party that does not have all progressive candidates. $^{63}$ At Council, the members one again condemned NDP members who voted for the

${ }^{58}$ Ibid, 6.

${ }^{59}$ Ibid, 7.

${ }^{60}$ August 1993 Council minutes. Given the subsequent election of Mike Harris in Ontario, these comments proved rather prophetic.

${ }^{61}$ Ibid, 16.

${ }^{62}$ December 1993 Council, President's Report, 4.

${ }^{63}$ Ibid, 5. 
Act, suggesting that no 'true trade unionist' would ever vote for the $A c t,{ }^{64}$ and that any NDP member who voted for the act should not receive union support in future elections. The December 1993 Council was full of calls to 'rebuild' the NDP - have CAW members join the party, nominate trade union candidates, and further trade union friendly policy planks. These members continued to see the NDP as the 'only party that would ever work with labour.' ${ }^{65}$

As we have seen, by the mid-1990s the union lacked a clear strategy for electoral political action. While the overarching strategy was one of 'rebuilding the party,' the seeds for future electoral strategy - strategic voting - were to be found as well. The union recognized that if it was to support the NDP, it must also act to push the NDP to the left at the same time: 'one point is becoming increasingly clear: we cannot simply leave politics to the government we elected. Governments will stray unless they are held accountable. If we take the idea of social democracy seriously, then we have a responsibility to criticize. ${ }^{66}$ At the same time, council delegates, especially those from the left of the union, highlighted the union's responsibility to lead the broader working class: 'One of the problems here is that social democracy, like the NDP, they're in crisis in what they think as well ... it's very important that we begin to think that we might have something to say about social alternatives, about political alternatives, about economical alternatives that social democracy does not. ${ }^{97}$

1994 - 1998: In the Political Wilderness

The Ontario NDP was defeated in 1995 and the Progressive Conservative party, under Mike Harris, was elected to form a majority government. This government would turn out to be

\footnotetext{
${ }^{64}$ December 1993 Council minutes, 43.

${ }^{65}$ Ibid.

${ }^{66}$ December 1992 Council, President's report, 38.

${ }^{67}$ Herman Rosenfeld, December 1992 Council minutes, 15.
} 
one of the most right-wing governments in Canada, fully embracing neoliberalism. ${ }^{68}$ As the depth of the Harris government's commitment to neoliberal reforms became ever more apparent, the CAW committed a good deal of time and effort to opposing the government. The opposition to the Harris government was rooted both in a concern for a loss of CAW jobs through further plant closures, and support for a social democratic vision for Canadian society.

Much of the opposition to the Harris government took the form of extra-parliamentary action. One of the largest, most sustained and visible forms of extra parliamentary action came in the form of the Ontario Days of Action. Shortly after the election of Harris many unions and social movements had begun to organize against the hard-right politics of this government. The Days of Action were one-day city-wide protests in the province, where workers would hold rallies and demonstrations in the streets against the government. What made them particularly interesting was that in most cases, the workers were leaving work to attend these demonstrations - in other words one-day "illegal" strikes by unionized workers who walked off the job during the term of a collective agreement. The plan for single-day strikes were presented to the membership at the workplace level, and these "illegal" strikes were endorsed by the members, usually with well over $90 \%$ of the membership voting in favour. ${ }^{69}$

The Days of Action remain exceptionally important to the political history of the CAW as it was one of the first instances of the CAW moving 'away from strictly defining politics as electoral ... the emphasis became on extra-parliamentary because the electoral space wasn't there. ${ }^{70}$ The first Day of Action took place in London and this was quickly followed by another in Hamilton. In both cases, CAW members closed all CAW workplaces, forfeiting a day of pay

\footnotetext{
${ }^{68}$ April 1995 Council minutes, 115.

${ }^{69}$ Tim Carrie, in discussion with the author, July 2013.
} 
to protest the Harris government. ${ }^{71}$ Such action represented a rare instance of the CAW being prepared to use its significant economic power to further an explicit political agenda. What made this particularly significant was the high degree of class-based action. CAW members engaged in a solidaristic class-based action, with all workers at all CAW workplaces walking off the job.

In other words, as neoliberalism has seen the ever-increasing separation of politics and economics, the Days of Action represented a very different vision of political action by unions. CAW members seemed acutely aware of this. At the April 1996 Council, delegates continued to rise in favour of the Days of Action. Some delegates spoke candidly that the Days of Action were a way for the CAW to expand well beyond challenging the Harris government and could be used to criticize the broader neoliberal political agenda; others went further still, arguing that the Days of Action were allowing the union to challenge capitalism itself. ${ }^{72}$ The CAW support, and leadership of the Days of Action, saw the union take a political stance to the left of the NDP, and one where they acted in unity with the broader working class. ${ }^{73}$

The Days of Action reached their zenith late in 1996. On October $25^{\text {th }}$ of that year, over a million workers stayed off the job in Toronto, causing all CAW workplaces in the city to either close or be rendered unable to operate because so many workers took the day off. ${ }^{74}$ While the CAW, along with other social movements, was pressing for the Days of Action to continue and expand, they ultimately fell apart due to infighting in the Canadian labour movement. Many unions in Ontario, especially the Steelworkers, who were long-time supporters of the NDP,

\footnotetext{
${ }^{70}$ Herman Rosenfeld, in discussion with the author, August 2013.

${ }^{71}$ April 1996 Council, President's report, 1.

${ }^{72}$ April 1996 Council minutes.

${ }^{73}$ Sam Gindin, in discussion with the author, August 2013.

${ }^{74}$ December 1996 Council, President's report, 1.
} 
refused to participate in further Days of Action unless a speaker from the NDP was present. These unions wanted to contract the scope of the Days of Action to focus solely on electoral politics - the removal of Harris and his replacement with an NDP government. The CAW was critical of this, calling on the other unions to continue to participate. Eventually the Days of Action fell away, as fewer and fewer unions participated. The CAW however remained hopeful that the Days of Action could be renewed. In 1997, the union called on all Ontario locals to work with the OFL to launch a one-day province-wide general strike. ${ }^{75}$ When, however, the Days of Action collapsed and the general strike failed to occur, Hargrove wasted no words casting the blame on the other, NDP-centric, unions: 'there was no stomach amongst the labour movement to move ahead and shut down the entire province. Our union, I believe, could have and would have kept our commitment. ${ }^{76}$

Debates over NDP participation in the Days of Action were but one factor in a larger process of soul searching within the union with regard to its relationship with the NDP. The overarching goal of both the leadership and many delegates was a plan to rebuild the NDP. After the Liberals won the 1993 federal election and NAFTA was brought into effect, the union started to distance itself from the federal NDP, arguing there was a need for a 'a more daring, imaginative, and challenging agenda than we have seen so far. ${ }^{77}$ One of the first instances of the rebuild-the-party strategy was a call for CAW members to go to the federal NDP convention and help give the party direction. This was greeted somewhat warmly by delegates. Thus one noted that 'I agree with him [Buzz] that we need to send delegates to the convention and have input and do as much as we can from within, but I just want to remind people that I haven't

\footnotetext{
75 December 1997 Council minutes, 42.

${ }^{76}$ August 1998 Council, President's report, 14.
} 
heard anybody apologize for the social contract yet.' $78 \mathrm{CAW}$ staff also encouraged 'maximum affiliation to the NDP to exercise our influence to the maximum. ${ }^{, 79}$

At this juncture, the CAW saw itself as a leader of the broader working class movement and this contributed, in part, to its position on the NDP. While still feeling betrayed by the party, the union argued that electing New Democrats would contribute to the protection of social programs that benefited both CAW members and workers who were not organized. ${ }^{80}$ It was also around this time, however, that CAW activists came to terms with the fact that rank-and-file members of the union were increasingly voting conservative, and that the union needed to mobilize not only to push the NDP to the left but also to push its own members to the left: 'the perspectives of the membership, the rank and file today, they're political ideas or conclusions they came to that are popping fresh solutions out of the Toronto Sun, or the Sun Newspapers. ... If the NDP is going to matter politically, it's going to matter because our union makes a real fundamental stab into politics. ${ }^{, 81}$

The union set out with the dual goal of pushing the NDP to the left, and convince its own members to participate in left electoral politics.

The union did find some evidence that its strategy of rebuilding the party had some merit. When it criticized the federal party for announcing it would seek closer ties to business, this and resulted in some 'backtracking' by the federal NDP. Moreover, the Labour caucus of the NDP was emerging as the left caucus of the party. ${ }^{82}$ In addition, the union continued to support the NDP in the Western provinces, seeing these parties as much more left wing and less problematic

\footnotetext{
${ }^{77}$ April 1996 Council, President's report, 18.

78 April 1996 Council minutes, 59.

${ }^{79}$ Ibid.

${ }^{80}$ April 1997 Council, President's report, 8.

${ }^{81}$ April 1997 Council minutes, 7.

${ }^{82}$ December 1998 Council, national and area reps report, 27.
} 
than their federal and Ontario cousins. ${ }^{83}$

By the end of the 1990s however the union had become mostly disillusioned with the NDP. Part of the CAW's criticism was that the party had refused 'to challenge the power of capital. In fact, it wanted to be the friend of capital. ${ }^{84}$ As noted in chapter one, through the 1990s many social democratic parties world-wide had neoliberalized, abandoning Keynesianism, and failing to develop a clear critique of the politics and economics of neoliberalism. The NDP was no exception: while still being the most left electorally viable party in Canada, the NDP had nonetheless failed to present a clear alternative to neoliberalism in Canada.

Over the years the union had moved from unwavering support of the party, to a leftleaning critical support, to an attempt to retake the party from within. According to Hargrove, during the 1990s the CAW 'learned a valuable lesson. From here on, the CAW will not support NDP candidates unless they declare their personal commitment to protect the rights of unions and workers, preserve social programs, and support programs such as public housing, childcare, public education, and care for the less fortunate. ${ }^{85}$ While the CAW was distancing itself from the NDP, it was not ready to distance itself from electoral politics: 'we've got to have an electoral voice. We have to have the party ... If we can't build this party that we've been part of forming, we can't build another party. ${ }^{96}$ The CAW thus developed a two-pronged approach to electoral politics. The union continued to exert effort to attempt to rebuild the NDP and pull them to the left, but strategic voting against conservative parties began to figure more

\footnotetext{
${ }^{83}$ August 1999 Council minutes. Throughout the entire archival process, there was almost no mention, at all, of electoral politics outside of Ontario and the federal government. When other branches of the NDP came up, it was usually in the context of a member of the political action department providing a report that the NDP had won, or lost an election. The recommendations to support other wings of the party were infrequent, and rarely debated.

${ }^{84}$ Hargrove, Labour of Love, 144.

${ }^{85}$ Ibid, 160.

${ }^{86} 1996$ Collective Bargaining and Political Action Convention, President's address, 28.
} 
prominently in the union's electoral strategy.

1999 - 2010: The Long Road to Strategic Voting

In 1998, the CAW began to develop a strategy for the 1999 Ontario election. The Harris government in Ontario introduced draconian labour legislation, rolled back much of what remained of the welfare state, and provoked confrontations with public sector workers. For much of the Ontario labour movement, defeating Harris was paramount. It was this election that saw the CAW first propose a strategy of strategic voting, which they would later come to embrace. At the August 1998 Council, Hargrove announced that

'we only have a real potential in electing New Democrats in seven seats. Well, everybody knows, seven seats is not going to do much in terms of defeating the Harris Government. ... It may very well mean in some areas that we decide to support a Liberal where we can knock off a Tory Member of Parliament and if it can be shown that we can defeat the Harris Government. In other words, our strategy has to be to defeat the Harris Government in 1999.'87

This marked the first time the CAW would engage in strategic voting to attempt to block the Conservative party from forming the government.

Hargrove's call for strategic voting faced a great deal of opposition from both life-long New Democrats and socialists, albeit for very different reasons. One brother rose in opposition to the document, telling the Council 'I too, cannot vote Liberal. ... where is the evidence that a Liberal government will not do the same [as the Tories]? ${ }^{98}$ Some of the criticism of the plan was unabashedly socialist and rooted in a deep working class politics: 'capitalism and democracy are banging heads here and this is a way bigger than the Liberals or the NDP... This document states "the CAW advocates democratic socialism." The Liberals do not advocate democratic

\footnotetext{
${ }^{87}$ August 1998 Council, President's report, 16.

${ }^{88}$ December 1998 Council minutes, 33.
} 
socialism.' ${ }^{89}$ Reaction from life-long New Democrats was also strong. The retirees' chapter of the CAW, some of the strongest supporters of the NDP in the union, voted unanimously to support the NDP in the next election..$^{90}$ One New Democrat, harking back to Tommy Douglas' famous "Mouseland" speech, concluded the debate on strategic voting rather poetically: 'I am going to leave you with one question. Just one question, I don't know the answer, I do know the answer - pardon me. The Liberals, are they a white cat or are they a black cat? But I know they are a cat. ${ }^{, 91}$ While the socialist left and the centrist New Democrats were both vehemently opposed to strategic voting, they did not have enough votes to block the proposal. The overwhelming majority of delegates to the Council voted with the leadership, and the endorsement of strategic voting passed the council in December 1998.

Although the CAW worked with other unions and social movements in Ontario to form the Ontario Election Network (OEN) to coordinate strategic voting in the province, this initial attempt at strategic voting was a failure. Various members of the OEN endorsed different candidates in the same riding, their targeted ridings were not made public until very late in the campaign, and strategic voting was widely interpreted by news agencies and the general public as a call to 'vote Liberal, not NDP.'92 The OEN was however able to claim some moderate success. 26 ridings were selected, and the Progressive Conservatives won in fifteen but almost all of the OEN endorsed candidates increased their share of the vote from the previous election. ${ }^{93}$ Thus Hargrove claimed that the strategic voting scheme had been successful in that

${ }^{89}$ Ibid.

90 Ibid, 56.

${ }^{91}$ Ibid, 42.

92 Brian A Tanguay, "Parties, Organized Interests, and Electoral Democracy: The 1990 Ontario Provincial Election" in Political Parties, Representation, and Electoral Democracy in Canada, ed, William Cross (London: Oxford University Press, 2002). 151 - 153.

93 Ibid 154. 
it did not harm the NDP: 'my challenge to those and anyone else who says that strategic voting harmed our Party in terms of the number of seats won ... show me where strategic voting caused the loss of one NDP member. Not one. Every riding that we lost, we lost by at least 10 percent. ${ }^{94}$ Henceforth, the union would almost exclusively support strategic voting federally and in Ontario.

The strategic voting strategy was closely linked to the broader fight-back within the union against manufacturing plant closure. Indeed, Swartz and Warskett argue that 'strategic voting underlined the CAW's increasing defensiveness in the face of developments in the auto industry and its concern to protect its members' sectional interests. ${ }^{95}$ By the late 1990 s, the effects of the FTA and NAFTA were once again being felt by CAW members: plants were being closed, and the membership base of the union was shrinking. The CAW turned to many strategies to combat plant closure, and strategic voting was one of them.

Through the late 1990s the CAW moved closer to the federal Liberals. In 1998 the union was quite proud that, through intensive lobbying, it had been able to get the Federal Liberal government to back away from plans to eliminate a $6.7 \%$ tariff on imported assembled vehicles from offshore producers. ${ }^{96}$ The elimination of this tariff would have significantly harmed North American vehicle production, which could potentially lead to job losses or plant closures. Another shift that occurred within the CAW during the early 2000s was a more gradual acceptance that Free Trade was the new economic reality. To this end, when the federal government announced the potential of expanded free trade with the Americas, the CAW's

${ }^{94} 1999$ Political Action and Collective Bargaining Convention, President's address, 17.

${ }^{95}$ Donald Swartz \& Rosemary Warskett, "Canadian Labour and the Crisis of Solidarity" in, Rethinking the Politics of Labour In Canada, eds. Stephanie Ross \& Larry Savage (Halifax: Fernwood Publishing, 2012), 30.

${ }^{96}$ August 1998 Council, President’s report, 24. 
position was to encourage (Liberal) Prime Minister Jean Chrétien to 'take the lead in ensuring union rights, labour rights, environmental rights, and a commitment to a democratic society be part of any trade agreement. ${ }^{, 97}$

2001 presented a new opportunity for the CAW to pursue the strategy of changing the NDP from within. While ultimately unsuccessful, the events surrounding the New Politics Initiative show that the CAW remained committed to attempting to change the NDP, which it perceived as having drifted to far from the guiding social democratic principles of the union. The NDP met in 2001 for a leadership review and policy convention. While there was not a serious challenger to leader Alexa McDonough, there was a good deal of anticipation due to the presence of the New Politics Initiative (NPI, an up-start renewal group).

The NPI was a faction within the NDP which situated itself to the left of the party's leadership and establishment, but not as left as the NDP's Socialist Caucus. Formed as a loose coalition of unions, anti-globalization activists, feminists, LGBTQ activists, and environmentalists who wished to move the party back to the left and reconnect the party with the base, the NPI believed that the NDP was shifting to the right and sought to push the party back left. The NPI also called on the party to work more closely with social movements. Going into the convention, the CAW supported the NPI's renewal effort.

Hargrove had helped to initiate an early form of the NPI by calling a meeting with members from the CAW (Hassan Yuseff, Peggy Nash, Sam Gindin), and prominent left academics (Leo Panich, Greg Albo) to discuss the rightward drift in the NDP and the need to move the NDP back to the socialist left. Subsequent meetings involved other prominent names

\footnotetext{
${ }^{97}$ April 2001 Council minutes, 54.
} 
on the Canadian left - Mel Watkins, Naomi Klein, and Judy Rebick. ${ }^{98}$

The CAW's perceived need to renew the NDP was rooted in its definition of class interests, and formed part of the union's plan to change the NDP from within. While the union had been moving closer to the Liberals, it still saw the NDP as having a different class base from the Liberals and the Conservatives. ${ }^{99}$ The CAW supported a

'new manifesto based on principles and values debated and adopted by Convention, a leadership convention in the spring of 2002, that we continue to elect a leader of our party at convention, that we support a new financial structure based primarily on the government financing formula for all parties, supplemented only by individual donations with a reasonable maximum amount, no corporate or union donations allowed.' 100

The desire to change the funding formula for the NDP was rooted in two interrelated factors.

First, one of the recurring criticisms of the NDP by the CAW was that the party asked unions to 'pay the bills and give us the foot soldiers to put up the signs and distribute the leaflets and keep your mouth shut; ${ }^{101}$ and second 'one thing that is coming across clear in our outreach to our members is that our members do not like us financing any party. They want to be left to do their own politics. They want the union to provide a lot of information, but our members find it very offensive that the union is funding a party that they don't necessarily support. ${ }^{\text {'102 }}$

At the NDP convention in 2001, the NPI proposal was debated by the party where it was loudly criticized by the party establishment for failing to detail a plan on how, exactly, to better incorporate social movements into the party - a key demand of the NPI. The NPI proposal went on to be defeated on the floor of the convention, albeit with $40 \%$ of the delegates voting in

${ }^{98}$ Gindin, discussion, August 2013. Gindin suggests, quite strongly, that Hargrove was not serious about moving the NDP to the left, but, rather was "stirring up some shit to get the NDP to take him seriously." Whether this was the case or not, the NPI remained significant to the NDP's political direction in the early 2000s.

${ }^{99}$ April 2001 Council, President's report, 58.

100 April 2001 Council minutes, 72.

${ }^{101}$ April 2001 Council, President's report, 63. 
favour of it.

The CAW took the defeat of the NPI as a defeat of the labour movement and its goal of moving the party back to the left. Hargrove immediately charged that the leadership of the party was out of touch with the base of the party: 'the leadership of our party just does not get it. We have policies that are reasonably good. In almost every area, these policies are much better than any other of the other parties.' ${ }^{103}$ One Council delegate concluded that if the NPI 'did not succeed then, in effect, it set the stage for this union to look to taking concrete action in the direction of building a political alternative to the left of the NDP. I think we've reached that point. I think it should be obvious to everybody the NDP is not going to be changed.' ${ }^{104}$ The December 2001 council was full of speakers expressing a general disappointment with the NDP and a recognition that the party was slipping further to the centre.

While the union was criticising the NDP for moving towards the centre, the CAW continued to alter its electoral politics strategy, deepening its commitment to strategically working with the Liberals. The CAW was increasingly seeing the NDP as unable to offer an alternative to neoliberalism, and was more willing to support a party that would support the auto industry, in the hopes that this support would translate into jobs for CAW members. This caused the rift between the NDP and CAW to grow and eventually to become public. In December of 2000, Hargrove and (Ontario NDP leader) Howard Hampton engaged in a public war of words. After Hargrove had mused, again, about strategic voting, Hampton held a press conference to tell the press that he considered Hargrove to be a Liberal supporter, and encouraged New Democrats

\footnotetext{
102 Ibid, 58.

103 December 2001 Council, President's report, 30.

${ }^{104}$ December 2001 Council minutes, 123.
} 
to stop listening to Hargrove, because he was a Liberal. ${ }^{105}$ In the lead-up to the 2003 Ontario election, the CAW once again planned to run a strategic voting campaign to defeat the Progressive Conservatives, calling on members to target resources in all ridings where there was a chance of defeating a sitting PC member. ${ }^{106}$ With this recommendation Hargrove clarified that in a race between the NDP and the Liberals, the CAW would 'always' support the NDP. ${ }^{107}$

The recommendation to endorse strategic voting was debated, however there was less vocal opposition to it this time around. A retired council delegate challenged the leadership to provide proof that 'the Liberals will be better than the Conservatives' ${ }^{108}$, while another delegate pointed out that the Liberals' positions on many policies of importance to the CAW were unclear: 'what about the Liberal position on unionization in the agriculture workers in farms across Ontario? How about the position the Liberals in Ontario have on deregulating hydro? How about the Liberal position on social assistance rates, minimum wage and so on? The fact is, it's important to get rid of shit, but you don't replace it with more shit ... Let's improve the NDP, make it a socialist party.' 109 The council eventually endorsed the call for strategic voting, with very few voices acting in opposition. ${ }^{110}$

The CAW's strategic voting strategy contributed to the victory of the Ontario Liberals in the 2003 provincial election. ${ }^{111}$ Hargrove was very pleased with the electoral outcome,

\footnotetext{
105 April 2001 Council, President's report, 60.

${ }^{106}$ December 2002 Council, President's report, 9; December 2002 Council minutes, 73.

${ }^{107}$ December 2002 Council minutes, 77.

108 Ibid, 81.

109 Ibid, 82.

110 Ibid.

111 The 2003 election saw the rise of the Working Families Coalition, a group of unions, led by the CAW, which organized a strategic voting campaign in this election. The WFC would go on to organized strategic voting campaigns in all subsequent Ontario elections to date, as well as in federal elections. Walchuk argues that the WFC is indicative of a 'middle class unionism' by the unions involved. The unions involved campaign for the Liberals expecting Liberal governments to introduce legislation that specifically benefits their members, rather than the entirety of the broader working class. For this analysis, and a history of the WFC, see Walchuk, "Changing Union-
} 
expressing the hope that the McGuinty Liberal government would be a progressive government, and, perhaps more importantly, one closely aligned with the interests of the CAW: 'for the first time, I was invited to the swearing in of the cabinet and invited to the Throne Speech ... For the first time in eight years, there was talk about the importance of government, of rebuilding our healthcare and education, increasing the minimum wage, freezing auto insurance. ${ }^{112}$ The 2003 Ontario election thus helped solidify the change of electoral strategy, at least in Ontario, for the CAW. From this point onward the union engaged in strategic voting campaigns designed to keep conservative parties out of power, which often meant working closely with the Liberals.

At the federal level, the CAW was moving away from the NDP as well, but at a different pace. In the 2001 federal election Peggy Nash, the assistant to Hargrove and White, ran as a New Democrat in a Toronto-area riding. The CAW supported Nash in the election, but seemed to be pulled in two different directions. The April 2004 Council debated two recommendations. The first asked for the union to participate in the CAW-CLC labour issues campaign - essentially a strategic voting campaign. The move to strategic voting was partially informed by the union's to "not tell the members how to vote," but rather to select issues of importance to "the workplace, community, and children,' and inform members where the parties were on these issues. ${ }^{113}$ The second called on the CAW to 'double its efforts to elect as many New Democrats as possible in the upcoming federal election. ${ }^{114}$ The CAW did highlight issues of importance to members, and did outline the positions of the parties, but the messaging from the union closely aligned with the messaging from the NDP, and was at least implicitly a call for members to vote NDP. ${ }^{115}$ While

Party in Canada," 2010.

${ }^{112}$ December 2003 Council, President's report, 23.

113 April 2004 Council minutes, 14.

${ }^{114}$ April 2004 Council minutes, 15.

115 This mirrors, very closely, what others have said about the CLC's "Better Choices Campaign": that 
the union was endorsing a strategic voting campaign but one in which it wanted as many NDP candidates to get elected as possible, some members, especially those on the left of the union, were sharply critical of this strategy, as they believed that 'the NDP has not been, in the latest years, a true socialist party.'116

During the early 2000s the union remained a supporter of the NDP, despite the defeat of NPI. To start, the union donated $\$ 500000$ to the party to help construct a new party headquarters. ${ }^{117} 2003$ saw a leadership convention within the NDP, and the CAW saw, once again, an opportunity to change the party from within. Hargrove briefly considered running for leadership of the NDP, but decided against it after determining that his candidacy would be deeply divisive within the party and could potentially do more harm than good. ${ }^{118}$ Jack Layton , who won the 2003 leadership race, had supported the NPI, although he had never joined the group. Because of this, many on the left of the party the CAW included saw Layton's leadership as a potential move towards the left by the party. As the 2004 election approached, the CAW became excited at the prospect of, first, electing a 'left opposition' in the House, led by Layton, and later, the potential to have the NDP influence a minority government. ${ }^{119}$

At this time the North American auto industry had gone into a sharp decline, as free trade increasingly led to more imports, plant closures, and job losses. This however drove the CAW to intensify its efforts to work with the Liberal parties federally and in Ontario as the latter were generally supportive of the automotive industry. This support came in the form of support for

while the union may be informing members of the different policy planks of the different parties, there was often a 'partial convergence' between the language of the CLC, and its affiliates, and the NDP, implicitly endorsing the NDP and encouraging union members to vote NDP. See Alan Whitehorn, "The NDP and the enigma of strategic voting", 2006 and Harold Jansen \& Lisa Young, "Solidarity forever?," 2009.

116 April 2004 Council minutes, 20.

117 December 2003 Council minutes.

${ }^{118}$ December 2002 Council, President's report, 41. 
automotive corporations: tax breaks and other incentives for automotive manufacturers. Hargrove highlighted the Ontario government's commitment to Ford in Oakville, a GM Beacon Project, to Navistar in Chatham, and a potential Chrysler paint shop in Windsor. ${ }^{120}$ By extension this meant continued, even if short term, employment for automotive workers. While the Liberals did not make any promise to those working in the automotive sector, the Liberal government's support for the sector brought the CAW ever closer to the party. The Martin government was receptive to the $\mathrm{CAW}$, and the Prime Minster himself made promises to Hargrove that the Liberal government would ensure the future of the automotive industry in Canada and Ontario. ${ }^{121}$ The Ontario Liberal government was a friend to automotive corporations as well, providing a $\$ 500$ million fund to the auto industry. ${ }^{122}$ While the Liberal governments were supportive of the automotive industry, they were much less friendly towards workers. In the same report in which Hargrove lauded, the Ontario government for supporting the automotive sector, he admonished it for failing to bring in labour-friendly legislation, such as card-check certification and anti-scab legislation. ${ }^{123}$ A year later, while still supporting the Liberal's position on the automotive sector, Hargrove suggested that McGuinty's position on labour relations was similar to the previous Harris government's. ${ }^{124}$

Hargrove's position on strategic voting was challenged in the debate at the National Executive Board by Carol Phillips, then assistant to Hargrove, , who argued that it would confuse the ideological position of the union if the union started to 'act like a business that makes strategic decisions.' The CAW's 'base ideological position is closer to the New Democrats, then

\footnotetext{
${ }^{119}$ December 2003 Council, President's report, 20; April 2004 Council, President's report, 8.

${ }^{120} 2005$ Collective Bargaining and Political Action Convention, President's address, 10.

${ }^{121}$ April 2004 Council, President's report.

${ }^{122}$ Ibid.

${ }^{123}$ Ibid.
} 
[the union] has to espouse that ideological position.' ${ }^{125}$ The NEB did however endorse strategic voting, and some board members - especially Ken Lewenza - called for Hargrove to fire Phillips. In the end, the CAW fully committed to strategic voting at the December 2005 Council. The events of the council would make national headlines, and see the union criticized by the NDP, other progressives in Canada, and many members of the union. Going into the Council meeting, Hargrove called on the CAW 'to do everything we can to elect as many New Democrats as we can ... We are working for another Liberal minority government ... so that the NDP will hold the balance of power.' ${ }^{126}$

As noted, Hargrove's call for the CAW to support strategic voting was rooted in the union's continual opposition to free trade agreements as he had concluded that the only way the CAW could have 'political power' was to get the NDP to hold the balance of power, so the party would oppose the expansion of Free Trade. ${ }^{127}$ The plan for the CAW to endorse NDP incumbents and NDP candidates in "potentially winnable" ridings caused a good deal of debate on the floor. Again, there was opposition from both socialists and life-long New Democrats. Some members criticized the Liberals for not caring about workers and called on members to only vote for the NDP as the latter was - at least in their minds - the party that cared about workers. ${ }^{128}$

The major controversy at this Council meeting, however, was the special guest - Liberal Prime Minister Martin had been invited to address the Council. After Martin's speech Hargrove presented the Prime Minister with a CAW jacket and hugged him, which was seen by CAW

${ }^{124}$ April 2005 Council, President's Report, 4.

${ }^{125}$ Carol Phillips, in discussion with the author, August 2013.

${ }^{126}$ December 2005 Council, President's report, 21.

${ }^{127}$ December 2005 Council minutes, 28.

128 Ibid, 104. 
members and the larger Canadian public as an endorsement of the Liberals. The 'jacket incident' created huge waves within the CAW and the move to work closer with the Liberals was hotly debated. ${ }^{129}$ Members of the NEB lined up to support Hargrove's recommendation, arguing that the Liberals were the only party that the CAW could reasonably trust to put the union's issues on the federal agenda. ${ }^{130}$ Other NEB members were sceptical that the Liberals had 'seen the light,' characterizing them as opportunists, but suggesting that there was a chance to 'shape the opportunists to suit our agenda. ${ }^{131}$

Some of the non-NEB members remained opposed - and in some cases openly hostile towards working closer with the Liberals. One member criticized Martin as an embodiment of the free trade agenda the CAW had long opposed: 'Here's a guy a month ago in Argentina saying we're going to advance free trade to the FTAA. ... As a working class person, I thought: you son of a bitch. You know, you don't give a goddamn about the fortunes and the abilities of workers. ${ }^{132}$ Even with the opposition from socialists and New Democrat loyalists, however the recommendation passed overwhelmingly. The move to completely embrace strategic voting at the federal level remained in debate for some time. Hargrove argued that the union 'couldn't credibly tell our members that everything would change for the better if only we could elect the NDP. ... They don't want the union telling them how to vote. ${ }^{133}$ Another contributing factor to the move to provide much more support to the federal Liberals was Hargrove's expulsion from the NDP. After giving Paul Martin the jacket, an incensed NDP moved to kick Hargrove out of

${ }^{129}$ The importance of giving Martin the jacket cannot be understated. During my interviews, simply saying "let's talk about the 'jacket incident" would provide the immediate context needed. Other unionists and observers of the Canadian labour movement will frequently refer to Hargove "giving Martin the jacket."

${ }^{130}$ December 2005 Council minutes.

${ }^{131} \mathrm{Ibid}, 110$.

${ }^{132}$ Ibid, 107.

${ }^{133}$ April 2006 Council minutes, 10. 
the party - the NDP constitution forbids members from supporting parties other than the NDP. The NDP Provincial Council met shortly after the jacket incident, and on the morning of the meeting informed CAW representative Mike Shields that the Council would be debating the removal of Hargrove from the NDP. ${ }^{134}$ The NEB, in "response" to this, decided that they did not want the NDP 'dictating to the union' and voted unanimously to withdraw from the NDP. ${ }^{135}$

The recommendation to completely leave the NDP was, once again, hotly debated on the Council floor. Many members suggest it was not yet time to give up the strategy of 'taking the party back' and using CAW members to move the NDP to the left. ${ }^{136}$ Other members, from the left of the union, argued that the move to completely divest from the NDP made little sense, as the plan 'doesn't lay out a viable alternative, and there has to be an alternative. ${ }^{137}$ Other left members argued that the class base of the Liberals - Canadian business - would mean that there would always be fundamental differences between the party and the union, and, in the end, the Liberals would 'serve up more free trade. ${ }^{138}$ Herman Rosenfeld, a long-time voice on the CAW's left, supported the move from the NDP, listing the ever-mounting grievances those on the left had with the party: 'they accepted the call for wage controls when they were in power way back when neoliberalism began. They refused to really challenge free trade. They sponsored the Social Contract in Ontario. They refused to challenge imperialism. ${ }^{139}$

Savage argues that 'growing union support for strategic voting within the broader context of neoliberal restructuring, while different union activists promote strategic voting for different reasons, some unions traditionally loyal to the NDP have primarily come to embrace the tactic as

${ }^{134}$ Hargrove, discussion.

${ }^{135}$ April 2006 Council minutes, 20.

${ }^{136}$ April 2006 Council minutes.

${ }^{137}$ Ibid, 36.

${ }^{138}$ Ibid, 37. 
a method of shielding themselves from the worst excesses of neoliberal public policy. ${ }^{\prime 40}$ This was certainly the case with the CAW and the NDP, as CAW support of strategic voting was based largely on the desire to defend the auto industry, and by extension CAW members, from the realities of neoliberal public policy, combined with a growing disillusionment with the NDP. By the 2007 Ontario election however the union had completely embraced strategic voting. Indeed, the NDP seemed to be an afterthought to the union, as the achievements of the McGuinty Liberals for automotive capital were lauded. Hargrove asked CAW members to 'remember when the election is called ... we already have a commitment from Dalton McGuinty's Liberals to put $\$ 100$ million on the table if Ford comes up with a new product.' ${ }^{141}$ In his endorsement of strategic voting, Hargrove only mentioned the McGuinty Liberals, reminding CAW members of 'the work that the Liberal Party under Dalton McGuinty has done with us on the auto industry in Ontario and other issues, affecting poor people, poor working families. ${ }^{142}$ Similar sentiments were echoed when planning for a federal election, calling on the CAW to work with the CLC's Better Choices Campaign. ${ }^{143}$ The recommendations to support strategic voting both federally and in Ontario were seemingly accepted by the delegates to the Council - neither received the lengthy debate that they had in the past. The federal recommendation was passed after three members spoke in favour of strategic voting, with none opposed; the provincial one was endorsed after only two spoke in favour, again with none opposed. ${ }^{144}$ Electoral politics received

\footnotetext{
139 Ibid, 40.

${ }^{140}$ Larry Savage, 'Organized Labour and the Politics of Strategic Voting,' in Rethinking the Politics of Labour In Canada, eds. Stephanie Ross \& Larry Savage (Halifax: Fernwood Publishing, 2012), 75.

${ }^{141}$ April 2007 Council, President's report, 4.

${ }^{142}$ April 2007 Council minutes, 16. Interestingly, in discussion with the author, Jim Stanford - a very public face of the CAW - vehemently denied that the CAW ever endorsed the Liberals or Dalton McGuinty, even though the historical evidence suggests otherwise. The reasons why he denied this were unclear.

143 Ibid, 17.

144 Ibid, 9 \& 22.
} 
almost no further attention at CAW Council, as strategic voting had been accepted as the norm of the union. A brief note in the first Presidential report of Ken Lewenzea, in December of 2008, indicated that the CAW supported the Liberal-NDP coalition, backed by the BQ, to remove Harper from power in $2008 .{ }^{145}$

Thus by the late 2000s, strategic voting had become the CAW's electoral strategy. The union also saw itself as a lobby group, acting to advance the best interests of its members. Ken Lewenza described the CAW's political outlook as

'we favour a social democratic government versus a conservative government, but the fact of the matter is, politicians come and go, the trade union movement's objectives do not. ... I can meet with Dalton McGuinty as comfortably as I can meet with Andrea Horwath or Tim Hudak, because our principles on objectives don't change. ... It doesn't matter who's in power, we got to push them on the principled positions of the union. ${ }^{146}$

The union's politics, by the late 2000s, had seemingly slipped away from an ideological anchor in left-wing social democracy that was the guiding force at the birth of the union.

\section{Conclusions}

Over the course of two and a half decades the CAW's electoral strategy has always been linked to protecting jobs in manufacturing and fighting free trade, while pursuing a socialdemocratic vision for Canada. As this chapter has highlighted, at times these two goals were harmonious, and at other times they were seemingly at cross-purposes. This has seen the union to the left of the NDP, and at other times to a position which is much murkier. The shift to strategic voting can be read as a centrist shift within the union, as strategic voting means endorsing the Liberals, who are clearly to the right of the NDP. This slow evolution was the

\footnotetext{
${ }^{145}$ December 2008 Council, President's report.

${ }^{146}$ Ken Lewenza, in discussion with the discussion, July 2013.
} 
result of a number of factors including the NDP's own shift to the right. Like the Canadian UAW out of which it emerged, the electoral politics of the CAW have always been forged out of the melting pot of different left political identities held by the members. The CAW was home to left nationalists, social democrats, and socialists. The structure of the CAW Council allowed these ideas to inform political debates and positions of the union. At times, the Left activist base successfully pushed back against the leadership's political goals, but the positions the union have taken have largely been leadership directed.

The CAW's electoral strategy remained rooted in a concern for the manufacturing sector in Canada, and especially the manufacturing sector in Ontario. A strong automotive sector provides high and stable levels of employment for CAW members which, in turn, gave the union financial and political stability. As chapter four showed, the CAW long saw itself as a leader within the Canadian labour movement and the broader working class, but it was through it strong base in the auto sector and manufacturing that gave the CAW the means to support a strong, multi-faceted political agenda. It is accordingly through the importance of the auto sector to the union, and the union's role as a leader for the working class, that the changes in its electoral strategy can be understood.

Before the 1988 election the CAW was a comfortable and strong supporter of the NDP. There was a shared ideological commitment to social democracy that could be found in both the NDP and the CAW, and the CAW committed a great deal of human and financial resources to support the NDP during elections, and encouraged union members to join the party. The 1988 federal election challenged this relationship: the union felt that the party did not fight strong enough against free trade. This skepticism of the NDP grew exponentially after the Rae government passed The Social Contract Act. While the Act did not affect manufacturing, the 
CAW saw it as what it was - an attack on union freedoms; the union had long been a defender of all union rights, not just their own, and was vehemently opposed to the direction the NDP was taking. The Act signalled that the NDP had failed to offer up an alternative to the politics of neoliberalism, and the failure of the party to campaign solely on Free Trade in 1988, or to capture public dissatisfaction with the proposed Free Trade deal indicated that the NDP could not be thought of as a strong defender of the interests of the CAW.

Free Trade became a reality, and the consequences of the Free Trade agreement were felt by CAW members. Plants closed, work was moved across the globe, and CAW members lost their jobs or had hours cut. Waves of plant closures and layoffs pushed the union into a defensive posture, where they sought to do whatever they could to defend manufacturing jobs. This resulted in varying strategies electorally. First, the union sought to return the NDP to its social democratic base by acting within the party. When that did not happen, the union increasingly began to support strategic voting. The reasons behind strategic voting were twofold: first, the union sought to freeze conservative parties out of power, as the public policies advanced by these governments presented vast negative consequences for union members and the larger working class. Second, Liberal parties, when in office, were generally supportive of manufacturing, and especially automobile, capital. This support usually translated into jobs usually short term promises of employment - for union members. Thus, the move to strategic voting is best understood as a rational response to the hollowing out of manufacturing. The union was attempting to do whatever it could to protect jobs for its members. The protection of jobs was seen not only as the mandate of the union, but the avenue the union needed to keep its position as a leader within the labour movement.

A tension still exists within the CAW regarding strategic voting. Strategic voting was 
completely ingrained in the fabric of the union by the late 2000 s. The union sees itself as a strong supporter of the NDP, and frequently acts this way while publicly espousing strategic voting. The CAW still gives more money and organizational support to NDP election campaigns than any other union, save the Steelworkers. ${ }^{147}$ This tension can be explained through the CAW's roots in social democracy and the CAW's increasing move to act pragmatically to defend its members' interests.

In the early 2000 s, as the union was moving away from the NDP and more and more towards a strategy of strategic voting, it initiated a "Task Force on Working Class Politics,' led, in part, by Sam Gindin. The Task Force would involve surveys, focus groups, and interviews with rank-and-file members, with the goal of bringing union members and the union's politics more closely in line. The goal was also to move the union to the left, and embrace a much wider definition of politics, as well as putting more emphasis on politics through class power. The motivating force behind the Task Force, as described by Gindin, was

'the idea of developing the working class into a political force. One that is independent of business, oppositional to the status quo, confident enough to counter the dominant ideas in society with an alternative common sense and able to combine the defensive working people in their daily struggles with a longer term vision. Working class politics is, in short, about building a movement for social change.' 148

The Task Force found that over $90 \%$ of respondents believe that the union works for their best interests at the bargaining table, but that level of support drops quite dramatically when it came to electoral politics. The major reason behind this lack of support was the union's continual support of the NDP during election campaigns, something that did not resonate with

147 Jim Stanford, in discussion with the author, July 2013.

${ }^{148}$ December 1999 Council minutes, 46. 
the members of the union. ${ }^{149}$ Rather than encouraging members to continually vote NDP, the union started producing 'scorecards' around elections, ranking parties on issues, including manufacturing, public services, health care, etc. ${ }^{150}$ The union began to act as 'an independent voice on behalf of its members' during election campaigns. ${ }^{151}$ As a result of the report of the Task Force, the CAW leadership began to speak of a 'more independent political base among members' and a politics that 'genuinely reflect the day to day hopes and concerns of our members rather than telling them to vote for a party that most do not support.' ${ }^{152}$ While this was the repeated calls by the leadership, in practise, as outlined above, the CAW moved further to strategic voting, and still had a political action agenda that was quite heavily driven by the union's leadership.

Like many of the other positions and policies of the union, the electoral strategy has been leadership driven, albeit with input from membership activists. Virtually all of the decisions surrounding political action were made by the National President or the National Executive Board, and then brought to Council for debate and endorsement. In all cases, the wishes of the leadership were endorsed by the activists at Council. The Council, though, provided a forum for exchange between the leadership and the rank-and-file: the rank-and-file was able to criticize, and in some small ways alter, the politics of the leadership, and the leadership was able to provide information to the rank-and-file, and to convince the broader membership of the goodness of their strategy. In some cases, the CAW used the council as a vehicle of political education or to put a face on the decisions the leadership was supporting. For example, during

\footnotetext{
${ }^{149}$ December 2001 Council, President's report, 38.

${ }^{150}$ Jenny Ahn, in discussion with the author, June 2013.

${ }^{151}$ Stanford, discussion.

${ }^{152}$ April 2006 Council, President's report, 9.
} 
the 2008 prorogation 'crisis,' the union invited Jack Layton to the council to explain to delegates why the NDP was supporting a coalition with Liberals, and what the CAW might expect from a coalition government. ${ }^{153}$ The council also allowed for activists to question and criticise the political decisions made by the leadership, which, in some cases, allowed for a slightly modified form of the recommendation to go forward.

${ }^{153}$ Lewenza, discussion. 


\section{$\underline{\text { Conclusion }}$}

\section{Introduction}

This dissertation was initially motivated by a desire to explain an apparent rightward drift within the CAW. In many respects, from its birth the union was on the left of the Canadian trade union movement, but it became a union that was prepared to make major concessions at the bargaining table and politically embraced strategic voting. The dissertation provides an explanation for this apparent drift. However in the course of the research, more discoveries about the CAW were made. In particular, the CAW Council's role in contributing to class formation were highlighted. The dissertation thus brought into view role the CAW played in building a class based politics that takes equity and equality seriously, incorporating equity seeking groups into the union in meaningful ways, which enriched the concept of class formation.

The CAW faced the challenge of deindustrialization and plant closures throughout its brief history, and the response to these challenges explain the way the CAW made decisions. On the one hand, in a response to plant closures, the CAW organized outside of its primary focus auto and auto parts manufacturing - bringing in new workers to the union, many of whom were from equity seeking groups. The inclusion of these workers both presented a challenge to, and enriched, the process of class formation. On the other hand, the CAW also looked to electoral politics to fight plant closures, moving from being a staunch partner of the NDP to embracing strategic voting. This dissertation examined these various factors - equity politics, electoral politics, and the impact of neoliberal globalization - to explain the union's complex response to these challenges, as hammered out through Council. 
The dissertation has argued that the CAW Council, especially the debates at council, the central forum for dialogical discussion within the union, sought to contribute to the formation of a class identity within the union. Council brought together activists from different sectors of the union, from different geographical locations of the union, as well as activists with substantially different identities. Council acted as a forum for these activists to see the similarities in their class position and work towards a common political strategy to advance the best interests of the union and the Canadian working class. Indeed, many of the debates at Council centred on how a particular policy would help both CAW members and workers who were not members of a union. The Council, acting as a forum for dialogue, also served as the main place for the union to develop its strategic responses to the challenges that the union faced. The linkages between mid-tier activists and the leadership forged through the Council helped the leadership to learn of rank-and-file concerns and exposed mid-tier activists to the leadership's way of thinking. No other union in Canada has a forum quite like the Council: while many unions have conventions, they do not meet as frequently, or involve as much interactivity as the Council did. The existence of a body like the Council, which incorporates the mid-tier activists into the union, helped to develop class-based understandings.

The leadership of the CAW is in a strong position, but analysis of Council minutes suggests a more nuanced view of the relationship of leadership, members, and mid-tier activists. At the same time, as time went by, there was a distancing of the Council from the leadership. In the CAW's later years communication at council started to heavily favour the leadership, shifting to a more monological form of communication. Hargrove held fewer council meetings that White did, while Lewenza stopped submitting written reports to council. More guest speakers were invited to the council and there was less debate about the President's report. During 
White's leadership, and the early years of Hargrove's presidency, there were long sections of the report were subject to debate. By the end of Hargrove's leadership, and through the Lewenza years, there was almost no debate on the President's report. These changes reduced the importance of Council, and allowed the leadership more latitude when it came to crafting and implementing union policy. This suggests that over time, the organization became more oligarchic in nature. This may well have reduced its capacity to contribute to class formation. While the CAW faced a number of external challenges, the strengthening of the position of the leadership vis-à-vis Council meant that it played less of a role in shaping the overall direction of the union.

The process of class formation involves a number of interlinking variables, including the outlook and strength of labour unions, social democratic parties, and the national political system. As Adam Przeworski argues, a struggle about class - to recognize that class is a salient political issue and to recognize one's class position - is a necessary prerequisite to a struggle by class. Brodie and Jenson show that this is further complicated in the particular case of Canada, as Canadian political culture has long been constructed around regional and linguistic cleavages that exclude class as a meaningful political variable for most Canadians - especially most Canadians of the working class. Unions are not the primary organizers of the working class workers are first organized in their workplace by employers. Unions, then, act as secondary organizers of workers, and this organization is complicated by the fact that workers have other identities beyond their position in the workplace: gender, race, sexuality, and ethnicity, among many other variables, shape the identity of workers. Equity seeking groups were present in the Canadian UAW and the CAW, but it was not until the 1970s that these groups confronted the union to seek better incorporation. 
Class formation is further complicated by exogenous political and economic factors; in this case study, the political, economic, and ideological realities of neoliberalism further restricted class formation. These external factors can put pressure on unions and restrict the options available to them, leading to moments of class deformation. The CAW had moments of class deformation around taking concessions at the bargaining table, moving to an electoral strategy of strategic voting, and moving away from dialogical discussions at Council. At the same time, the CAW experienced moments of class reformation when the union was able to construct a culture of working class solidarity, built around a shared vision for a more materially equitable Canadian society, and was, to varying degrees, able to fight for this vision through collective bargaining and political action.

Social democratic parties can have a role to play in class formation. Political parties allow for the articulation of the political demands of the working class as class-based demands, and acting as a challenge to traditional bourgeois parliamentary politics. Social democratic, and socialist parties, then, have a clear theoretical potential to act as vehicles for class politics. In order to be effective in the pursuit of class politics, social democratic parties and trade unions must broadly represent the same groups of people and must have a shared ideological vision. Esping-Andersen notes that the Nordic social democratic parties were able to construct strong cross-class alliances by casting themselves as the party of a wage-earner class - this strategy, however, was almost exclusively found in the Nordic social democratic parties. Many social democratic parties, including the NDP, built an identity in the post-war period around being strong defenders of the Keynesian Welfare State.

The CAW did not, by the 1990s, have a shared ideological vision with the NDP. The union wanted a social democratic, if not a socialist, Canada. Barring that, the union would 
support a government that would protect the auto industry, as the auto industry held a privileged position within the union. The NDP offered neither of these - a vision for a socialist Canada nor the ability to protect the auto industry - to the CAW, so the union set out on a path that did not necessarily closely involve a political party in class formation. The larger political strategy of the union, including the electoral strategy, has always been about protecting jobs and fighting free trade. Supporting the Liberals occurred after the NDP could not offer a viable alternative to neoliberalism, and could not get elected.

\section{The CAW's Working Class Politics}

The decline of the Canadian automotive industry, manifested in plant closures and manufacturing restructuring, was very much precipitated by neoliberal globalization.

Neoliberalism presents an ideological threat to trade unions, as it challenges the legitimacy of unions and of collective solidarity. The CAW was able to maintain strong internal collective solidarity, even in the face of neoliberal restructuring, and used this internal solidarity to foster a working class politics to fight back against the neoliberal attack on the legitimacy of unions.

Upchurch et. al. suggested that, in the face of neoliberalism, there are three opportunities that trade unions can pursue. First, unions can appeal to business competitiveness. While some of the actions of the CAW can be interpreted as appealing to business competitiveness, the actual actions are much deeper than this. In the mid-to-late 1990s, the CAW adopted an electoral strategy which, was largely based on supporting political parties that would ensure auto manufacturing would continue in Canada. The CAW's electoral support of the Liberals through strategic voting can be seen as appealing to the competitiveness of the automotive industry, this was primarily driven by a desire to keep jobs for autoworkers; it was not a shift to undermine collective agreements in the name of appealing to business competitiveness. Second, for 
Upchurch, unions can lobby the party of labour to return to traditional social democracy. This represented a key strategy for the CAW. The union sought to pull the NDP back to the left, and to build a strong left-labour party. It was only when these efforts failed, and the NDP failed to articulate a clear alternative to neoliberalism, that the CAW embraced strategic voting. Lastly, unions can liberate themselves from institutional fetters and establish themselves as movements. While the CAW was attempting to build itself as a larger working class social movement of the left, the union did often rely on institutions: it always had an electoral strategy, would lobby politicians for changes to policies, and would sometimes rely on the court system to pursue policy changes.

The ongoing impact of plant closures constituted an important external challenge to which the CAW had to fashion a strategic response. Plant closures resulted in the shrinking of its core membership base. The resulting decline in its dues base affected the union's capacity to participate in political action - a strong auto sector allowed the CAW to spend money on campaigns and actions on other sectors. Moreover, the collective agreements in auto had been the union's strongest and most comprehensive collective agreements in the union, and possibly some of the strongest and most comprehensive agreements in Canada. While the CAW did become a multi-sector union, the importance of automotive manufacturing, as well as automotive parts manufacturing, for its position cannot be underestimated. The health of Canada's auto manufacturing sector continued to hold a privileged place within the CAW's calculations.

The CAW fought back against plant closures using an array of political actions. Unions, when faced with challenges, have numerous potential solutions open to it. It could choose to participate within political institutions - i.e., through electoral politics or court cases - or it might chose an extra-institutional route. What path the union embarks on depends a great deal on 
political-economic environment at the time. For example, in the 1990s in Ontario, the CAW was a major force in the Days of Action. The relative weakness of the NDP at that time, coupled with strong solidaristic bonds between unions, all of which felt under attack by the government of Ontario, led the CAW to participate in a more militant form of fight-back that they may not have chosen to undertake at other points in time.

Its main locus of political action against plant closures was electoral politics. Initially the CAW was a staunch supporter of the NDP, encouraging members to vote NDP, and donating money and time to the party. After the NDP's failure in the 1988 federal election, and the subsequent Rae government in Ontario, the CAW loosened its ties with the party. While still offering critical support to the party during elections, the union initially acted as a left critic of the party - pushing the party to become more left. As the plant closures continued unabated, however, the union embraced strategic voting - voting for any party which could defeat the conservative party during elections. The union's support for the NDP initially reflected a shared ideological commitment to social democracy. As neoliberal policies continued to erode the union's economic position, however, the union began to look to the Liberal Party of Canada (and Ontario), as the party best able to assist the manufacturing sector. The turn to strategic voting must however also be understood in terms of the union's disappointment in the NDP for failing to provide a critique of neoliberalism. While the CAW had a broad commitment to a social democratic, if not socialist, vision of Canada, the union's efforts to move the party to the left showed that the NDP was unable, or unwilling, to help deliver this vision.

One of the union's responses to the declining auto base of the union was to expand membership through mergers with other unions and organizing new workers into the CAW. As the union membership became more heterogeneous, the new groups of workers - racialized 
workers, women, LGBTQ workers, and workers in other industries - sought meaningful representation within the CAW. The struggle for representation took many forms, but a great deal of it happened at CAW Council, where mid-level activists were able to push the union's leadership, as well as other activists, for representation. Although the leadership was also pushed into positive positions by rank-and-file activists who had strong equity commitments, the CAW leadership was very supportive of equity issues. One result of the integration of the changing face of the union, and the inclusion of equity seeking groups into the union, was that the CAW made the equity claims of various equity seeking groups a central part of its conception of working class solidarity.

As noted, the inclusion of equity seeking groups into unions can both frustrate and augment the process of class formation. On the one hand, the union becomes more heterogeneous, meaning that a variety of views and demands must be incorporated into the union's strategy. On the other hand, the inclusion of equity seeking groups opens the possibility of forging strong ties across the whole working class, by focusing on commonalities rather than differences, helping the process of class reformation. The CAW did a very good job of using diversity to enrich and strengthen and reform class politics. The struggles of equity seeking groups were cast, by both activists and the leadership within the union, as issues of working class struggle. The union's discourse stressed commonalities among workers with different identities, including the importance of improving the economic well-being of all members. This allowed the union to link concrete bargaining goals, like child care provisions, to similar concerns in broader Canadian society - like a national child care program. A working class identity was seen as the common bond between all the members of the CAW, and exerting the economic and political force of the union to seek gains was seen as the way a working class politics could be 
pursued through the union. The CAW was often a leader within the Canadian labour movement, and especially within industrial unions, on issues of equity, and incorporating equity into a broader working class politics. Equity politics are an integral part of a broader working class politics, and the CAW did an excellent job of incorporating these voices and issues into the way class politics was formed. The CAW can act as an example for many other unions within the broader Canadian labour movement, showing that the meaningful incorporation of equity politics strengthens working class politics.

Sam Gindin argued that unions act as sectional organizations, not class-specific organizations, as unions organize specific workers to confront specific employers. He went on to argue that, because of this, unions do not act to build the working class as a social force. While the CAW branched out from organizing primarily within automotive and auto parts, as a union engaged in collective bargainin, it primarily organized specific workers to confront specific employers. There was some deviation from this pattern - the workers at the Big Three tended to bargain at the same time - but primarily the union organized workers sectionally. At the same time, through the Council and an ideological commitment to working class politics, the union did attempt to build the working class as a social force. This is well reflected in its commitment to equity politics, an electoral strategy that often discussed political gains for the larger working class, and an overarching commitment to working class politics. The research in this dissertation suggests that the Council contributed to building the working class as a social force.

Extrapolating further, bodies like the Council could be used to coordinate bargaining: ending dates of collective agreements and common bargaining goals and language between different unions in the same sector, and even unions in different sectors, to help move beyond confronting specific employers by specific union members. 


\section{Directions for Further Research}

Przeworski argues that capitalism makes it difficult to see class interests, so struggles about the salience of class occur before classes can act. These insights helped guide the research into class formation at the CAW Council. Therborn notes that class formation, which was observed in the CAW, can be frustrated by class deformation and reformation and we have seen how all three processes were at work in the CAW. The contributions of Offe and Weisenthal, Douglas, and Sabel all provide insight into the complex processes of class formation. Offe and Weisenthal highlight two important points. First, as secondary organizations, unions confront the task of welding together a heterogeneous workforce. One of the ways leadership can do this is to have recourse to symbolic bricolage, which the CAW leadership used to link cultural practises in the union to larger struggles, especially around equity, is important for organizations and organizational leadership. Second, to weld these workers together around a collective, class identity it needs to be dialogical i.e. to engage the members in dialogue. Unions, through their dialogical communication between leaders and mid-tier activists, can thus help the process of class formation. This is where Sabel had insights to offer in highlighting the role of mid-tier activists in trade unions. The Council provided a good site from which to examine the 'mid-tier' activists whose importance Sabel rightly highlighted.

This study did not, however, look at the positions of rank-and-file members, or activists, of the CAW. This is certainly an area where future research projects could expand on the body of knowledge of the CAW. With respect to equity, there were some indications that there was pushback from rank-and-file members in the plants to equity provisions, especially around LGBTQ rights. There was a great deal of debate about the Framework For Fairness within the rank-and-file of the union. Research into rank-and-file dynamics and debate at key plants would 
complement the research done for this dissertation. Further interviews with rank-and-file members and activists could also cast more light on the ways that equity seeking groups negotiated spaces within the union: this dissertation focused on how these groups interacted with leadership and the Council, but further research could show how the organized outside of Council and on the plant floor.

Relatedly, the study could be repeated with a different sampling method for interviews. Interviewees were selected based on Council minutes, and from there, a snowball sampling technique was used to find other key elites within the CAW. The main strength of this sampling method was that it found virtually all of the key players at the CAW Council, and allowed great access to most mid-tier activists. Negative side of this technique, however, is that it produced a relatively circumscribed list of interviewees within the CAW. Some activists may have been missed, especially if they only participated in caucuses at Council, and did not speak at the mics, or if they were critical enough of the organization that they may not be recommended by elites within the CAW.

A decision was also made to focus on the CAW in English speaking Canada, in this dissertation. This had the effect of bracketing the experience of the Quebec wing. The decision made sense for this dissertation as the Quebec wing was, in almost every respect, autonomous from the CAW in English Canada. A fuller account of the CAW would however benefit from a comparison of the way in which the two wings of the union coped with deindustrialization and neoliberalism. How did the Quebec political and economic context affect the Quebec wing's choices? One key difference would likely be reflected in their electoral choices. The Quebec wing of the CAW never endorsed strategic voting, remaining a staunch supporter of the Bloc Québécois federally and the Parti Québécois provincially. 
Another line of investigation would be to look at what the CAW brought to the new union, UNIFOR, forged out of the September 2013 merger with the CEP. Both unions had become multi-sector unions, both of which who were rooted in manufacturing, and the general agreement was that a single, private-sector union would bring much more bargaining power, both at the bargaining table and in the general public, than the two unions separately. What would the culture of this new union be? Considering the CAW fully supported strategic voting and the CEP was a staunch supporter of the NDP, what would the electoral politics strategy be? How would the merger change the landscape of organized labour in Canada? At the time of this writing, many of these questions have not been answered, but there are some hints towards these answers. One interesting development out of the merger was the promise of "Unifor Community Chapters." These chapters would be a new way to organize workers into trade unions - explicitly workers who are usually excluded from union membership, i.e. those in workplaces where no union campaign has succeeded, the unemployed, contract workers, and students. This suggested a much grander vision of organizing that would see Unifor reaching out to the greater working class, using the union's political strength to support these workers. Could this indicate that the Unifor Community Chapters were representative of a great moment of class reformation? Research into the Unifor Community Chapters, as a form of organizing workers not yet seen before in Canada, is a research topic that could be explored.

Perhaps the strongest indicator of the new direction of Unifor can be found in the internal organization of the union and the first election for leadership positions. In contrast to the CAW's Council, Unifor has a much more diluted internal structure. Although the Quebec Council remains autonomous from English Unifor, the old CAW Canada Council has been split into four smaller regional Councils, one for British Columbia, Prairies, Ontario, and Atlantic. This 
suggests that the internal organization of Unifor will be much weaker than the CAW's and it will be much harder for mid-tier activists to organize and put pressure on the leadership. Indeed, Unifor's new constitution makes no mention of the Councils as a forum for holding the leadership accountable to the rank-and-file. This raises the question of how mid-tier activists and through them, the rank-and-file, can put pressure on the leadership. 
$\underline{\text { Interviews }}$

Ahn, Jenny. Head of the CAW Political Action department. 11 June 2013.

Allen, Malcolm. NDP MP for Welland, former financial officer \& CAW Council delegate for Local 199. 27 June 2013.

Buckley, Chris. CAW staff, former president of local 222, former GM master bargaining committee chair, former NDP candidate. 03 July 2013.

Carrie, Tim. Education department, former president of CAW Council, former president of local 27. 26 July 2013.

Carter, Sue. Education department, former member of the human rights department, former national Pride rep. 01 September 2013.

Lewenza, Ken. CAW national president, former president of CAW Council. 03 July 2013.

Gindin, Sam. Retired head of research; assistant to Bob White and Buzz Hargrove. 16 August 2013.

Gindin, Sam. Retired head of research; assistant to Bob White and Buzz Hargrove. 11 August 2011.

Hargrove, Buzz. Former National President of the CAW. 31 July 2013.

Kelly, Lisa. Director of CAW education department, former member of the legal department, initiator of the CAW pride portfolio. 01 September 2013.

Nash, Peggy. NDP MP for MP for Parkdale - High Park, former assistant to Bob White and Buzz Hargrove, staff liaison to CAW women's committee. 11 July 2013.

Phillips, Carol. Assistant to Bob White, Buzz Hargove, and Ken Lewenza. Bob White's assistant at CLC. Head of the Women's Department, Director of Political Action, Education, and the International Department. 28 August 2013.

Rosenfelt, Herman. Retired staff, education department. 07 August 2013.

Sharma, Vinay. Head of the CAW Human Rights Department. 25 July 2013.

Shields, Mike. CAW national staff, former president of local 222, former head of organizing, former head of International Solidarity, former NDP Candidate. 06 August 2013.

Stanford, Jim. Economist for the CAW. 30 July 2013.

Stuart, Ken. CAW national pride rep. 01 September 2013.

White, Julie. Head of the CAW Women's Department. 13 July 2013.

Works Cited

Abella, Irving. Nationalism, communism, and Canadian labour. Toronto: University of Toronto Press, 1973.

Albo, Greg. "The 'New Economy' and Capitalism Today." In Interrogating the New Economy: Restructuring Work in the 21st Century, edited by Norene J Pupo \& Mark P Thomas, 3 20. Toronto: University of Toronto Press, 2010.

Anastakis, Dimitry. "Between Nationalism and Continentalism: State Auto Industry Policy and the Canadian UAW, 1960-1970.” Labour/Le Travail 53 (Spring 2004): 89 - 126.

Bakan, Abigail B. \& Audrey Kobayashi. “"The Sky Didn't Fall': Organizing to Combat Racism in the Workplace - The Case of the Alliance for Employment Equity." In Race, Racialization, and Antiracism in Canada and Beyond, edited by. Genevieve Fuji Johnson \& Randy Enomoto, 51 - 78. Toronto: University of Toronto Press, 2007.

Berg, Bruce L. \& Howard Lune. Qualitative Research Methods for the Social Sciences, $8^{\text {th }}$ Edition. Toronto: Pearson, 2012. 
Briskin, Linda. "The equity project in Canadian unions: confronting the challenge of restructuring and globalisation." In Gender, Diversity and Trade Unions: International Perspectives, edited by. Fiona Colgan \& Sue Ledwith, 28 - 47. New York: Rougledge, 2002.

------. “Austerity, union policy and gender equality bargaining.” Transfer 20 no 1. (2014): $115-133$.

Brodie, Janine \& Jane Jenson. Crisis, Challenge, and Change: Party and Class in Canada Revisited. Ottawa: Carleton University Press, 1991.

Campbell, John L. "Institutional analysis and the role of ideas in political economy." Theory and Society 27 (1998): 377 - 409.

Canadian Autoworkers. "We're Building A Future Together! United in collective bargaining and political action." Document from the 1987 collective bargaining and political action convention.

-----. "Unions and Politics.” Document from the 1991 Constitutional Convention.

-----. "Past Gains, Future Challenges. Mobilizing for the New Millennium." Document from the 1999 Constitutional Convention.

------. "Bargaining in Tough Times.” Document from the 2002 Collective Bargaining and Political Action Convention.

------. "Building The Union in Hard Times." Document from the 9th CAW Constitutional Convention, 2009.

Carroll, William, \& R. S. Ratner, eds. Challenges and Perils: Social Democracy in Neoliberal Times. Halifax: Fernwood, 2005.

Darlington, Ralph \& Martin Upchurch. "A reappraisal of the rank-and-file versus bureaucracy debate." Capital \& Class 36, no 1 (2011): 77 -95.

Ehring, George \& Wayne Roberts. Giving Away A Miracle: Lost Dreams, Broken Promises \& The Ontario NDP. Oakville: Mosaic Press, 1993.

Esping-Andersen, Gosta. Politics Against Markets. Princeton: Princeton University Press, 1985.

Evans, Bryan. "The New Democratic Party in the Era of Neoliberalism." In Rethinking the Politics of Labour In Canada, edited by Stephanie Ross \& Larry Savage. Halifax: Fernwood Publishing, 2012.

-----. "The New Social Democracy." In Social Democracy After The Cold War, edited by Bryan Evans \& Ingo Schmidt, 1 - 11. Edmonton: Athabasca University Press, 2012.

------. "From Protest Movement to Neoliberal Management: Canada's New Democratic Party in the Era of Permanent Austerity." In Social Democracy After the Cold War, edited by Bryan Evans \& Ingo Schmidt, 45 - 97. Edmonton: Athabasca University Press, 2012.

Frank, J.A. "The "Ingredients" in Violent Labour Conflict: Patterns in Four Case Studies." Labour / Le Travailleur 12 (Fall 1983): 87 - 112.

Fowler, Tim. "Does Fighting Back Still Matter?: The Canadian Autoworkers, Capitalist Crisis and Confrontation." Capital \& Class 36, no. 3 (October 2012): 487 - 507.

Fudge, Judy \& Eric Tucker. Labour Before The Law: The Regulation of Workers' Collective Action in Canada, 1900 - 1948. Don Mills: Oxford University Press, 2001.

Gindin, Sam. The Canadian Auto Workers: The Birth and Transformation of a Union. Toronto: James Lorimer \& Company, 1995. 
------. "Up Against The Wall: The Political Economy of the New Attack on the Canadian Labour Movement: A Reply to Andrew Jackson." Just Labour: A Canadian Journal of Work and Society 20 (Summer 2013): $64-68$.

Hargrove, Buzz. Labour of Love: The Fight to Create a More Humane Canada. Toronto: McFarlane Walter \& Ross, 1998.

------. Laying it on the Line: Driving a Hard Bargain in Challenging Times. Toronto: HarperCollins, 2009.

Harvey, David. A Brief History of Neoliberalism. Oxford: Oxford University Press, 2005. Horowitz, Gad. Canadian Labour in Politics. Toronto: University of Toronto Press, 1968. Howell, Chris. "The End Of the Relationship Between Social Democratic Parties and Trade Unions?" Studies in Political Economy 65 (Summer 2001): 7- 37.

Hunt, Gerald. "Introduction." In Equity, Diversity, and Canadian Labour, edited by Gerald Hunt and David Rayside, 3 - 24. Toronto: University of Toronto Press, 2007.

Hunt, Gerald and Jonathan Eaton. "We are Family: Labour Responds to Gay, Lesbian, Bisexual, and Transgender Workers." In Equity, Diversity, and Canadian Labour, edited by Gerald Hunt and David Rayside, 130 -140. Toronto: University of Toronto Press, 2007.

Hyman, Richard. Marxism and the Sociology of Trade Unions. London: Pluto Pamphlets, 1971.

Ingrassia, Paul. Crash Course: The American Automobile Industry's Road from Glory to Disaster. New York: Random House, 2010.

Jackson, Andrew. "Up Against The Wall: The political economy of the new attack on the Canadian labour movement." Just Labour: A Canadian Journal of Work and Society 20 (Summer 2013): 51 - 63.

Jessop, Bob. "Towards a Schumpeterian Workfare State? Preliminary Remarks on Post-Fordist Political Economy." Studies in Political Economy 40 (Spring 1993): 7 - 39.

Kainer, Jan. "Gendering Union Renewal: Women's Contributions to Labour Movement Reviatlization.” In Unions, Equity, and the Path to Renewal, edited by Janice R Foley \& Patricia L Baker, 15 - 38. Vancouver: UBC Press, 2009.

Kumar, Pradeep \& John Holmes. "The Impact of NAFTA on the Auto Industry in Canada" in The North American Auto Industry Under NAFTA, edited by Sidney Weintraub \& Christopher Sands, 92 - 183. Washington: The Centre for Strategic and International Studies, 1998.

Leech, Beth L. "Asking Questions: Techniques for Semistructured Interviews." PS Political Science 35iss 4 (December 2002): 665 - 668.

Lewenza, Ken. "A New Union for Challenging Times: A Reply to Andrew Jackson.” Just Labour: A Canadian Journal of Work and Society 20 (Summer 2013): 69 - 72.

Lucio, Martinez. "Union politics, purpose and democracy: To be or not to be? Optimism, pessimism and the continuing importance of Richard Hyman's early contributions." Capital \& Class 36, no 1 (2012): 35 - 51.

MacDonald, Ian Thomas. "Towards Neoliberal Trade Unionism: Decline, Renewal and Transformation in North American Labour Movements." British Journal of Industrial Relations 52, no. 4 (December 2014): 725 - 752.

Mahon, Rianne. "Child Care in Sweden and Canada: Policy \& Politics." Social Politics 4 no. 3 (January 1997): $382-418$. 
Mahon, Rianne \& Deborah Brennany. "Federalism and the "New Politics" of Welfare Development: Childcare and Parental Leave in Australia and Canada." Publis: The Journal of Federalism 43 no 1(2012): 90 - 108.

Maroney, Heather Jon. "Feminism at Work." In Feminism and Political Economy: Women's Work, Women's Struggles, edited by Heather Jon Maroney \& Meg Luxton. Toronto: Methuen Publications, 1987.

McBride, Stephen. Paradigm Shift: Globalization and the Canadian State, $2^{\text {nd }}$ Edition. Halifax: Fernwood Publishing, 2005.

McBride, Stephen \& John Shields. Dismantling a Nation: The Transition to Corporate Rule in Canada, $2^{\text {nd }}$ Edition. Halifax: Fernwood Publishing, 1997. Milkman, Ruth. Farewell to the Factory: Auto Workers in the Late Twentieth Century. Berkeley: University of California Press, 1997.

Michels, Robert. Political Parties: A Sociological Study of the Oligarchical Tendencies of Modern Democracy. Translated and edited by Eden and Cedar Paul. Kitchener: Batoche Books, 2001.

Milkman, Ruth. Farewell to the Factory: Auto Workers in the Late Twentieth Century. Berkeley: University of California Press.

Moody, Kim. Workers in a Lean World: Unions in the International Economy. London: Verso, 1997.

Moschonas, Gerassimos. In The Name of Social Democracy. The Great Transformation: 1945 to the Present. Translated and edited by Gregory Elliot. London: Verso, 2002.

Offe, Claus \& Helmut Wiesenthal. "Two Logics of Collective Action: Theoretical Notes on Social Class and Organizational Form." Political Power and Social Theory 1, (1980): 67 115.

Panitch, Leo \& Donald Swartz. From Consent To Coercion: The Assault on Trade union Freedoms, $3^{\text {rd }}$ Edition. Aurora: Garmond Press, 2003.

Piketty, Thomas. Capital in the Twenty-First Century. Translated by Arthur Goldhammer. Cambridge, Massachussets: The Belknap Press of Harvard University Press, 2014.

Penner, Norman. From Protest to Power: Social Democracy in Canada 1900 - Present. Toronto: James Lorimer, 1992.

Przeworski, Adam. "Proletariat into a Class: The Process of Class Formation from Karl Kautsky's The Class Struggle to Recent Controversies." Politics \& Society 7, no. 4 (December 1977): 343 - 404.

Ross, Stephanie. "Social unionism in hard times: union-community coalition politics in the CAW Windsor's Manufacturing Matters Campaign." Labour / Le Travail 68 (Fall 2011): $79-119$.

Ross, Stephanie \& Larry Savage. "Rethinking the Politics of Labour in Canada: An Introduction." In Rethinking the Politics of Labour In Canada, edited by Stephanie Ross \& Larry Savage. Halifax: Fernwood Publishing, 2012.

Sabel, Charles F. "The internal politics of trade unions." In Organizing interests in Western Europe, edited by Suzanne Berger. Cambridge: Cambridge University Press, 1983.

Savage, Larry. "Organized Labour and the Constitutional Question," PhD diss., York University, 2006.

http://www.collectionscanada.gc.ca/obj/thesescanada/vol2/002/NR29523.PDF. 
------. “Contemporary Party-Union Relations in Canada.” Labor Studies Journal 35, no. 1 (March 2010): 8 - 26.

------. "Organized Labour and the Politics of Strategic Voting." In Rethinking the Politics of Labour In Canada, edited by Stephanie Ross \& Larry Savage. Halifax: Fernwood Publishing, 2012.

Schmidt, Ingo. "It's The Economy Stupid! Theoretical Reflections on Third Way Social Democracy." In Social Democracy After The Cold War, edited by Bryan Evans \& Ingo Schmidt, 13 - 43. Edmonton: Athabasca University Press, 2012.

Statistics Canada CANSIM database. Table 301-0001 - Manufacturing activities, by Standard Industrial Classification, 1980 (SIC), annual (dollars unless otherwise noted); accessed 03 October 2014.

Sugiman, Pamela. "Privilege and Oppression: The Configuration of Race, Gender, and Class in Southern Ontario Auto Plants, 1939 to 1949." Labour / Le Travail 47 (Spring 2001): 83 113.

------. Labour's Dilemma: The Gender Politics of Autoworkers in Canada, 1937 - 1979. Toronto: University of Toronto Press, 1994.

Swartz, Donald \& Rosemary Warskett, "Canadian Labour and the Crisis of Solidarity." In Rethinking the Politics of Labour In Canada, edited by Stephanie Ross \& Larry Savage. Halifax: Fernwood Publishing, 2012.

Tanguay, A. Brian. "Parties, Organized Interests, and Electoral Democracy: The 1999 Ontario Provincial Election." In Political Parties, Representation, and Electoral Democracy in Canada, edited by William Cross. London: Oxford University Press, 2002.

Therborn, Göran. "Why Some Classes Are More Successful Than Others," New Left Review 138 (March-April 1983): 37 - 55.

Upchurch, Martin, Graham Taylor, \& Andrew Mathers. The Crisis of Social Democratic Trade Unionism in Western Europe: The Search for Alternatives. Surrey: Ashgate, 2009.

Walchuk, Bradley. "Changing Union-Party in Canada: The Rise of the Working Families Coalition." Labor Studies Journal 35, no 1 (March 2010): 27- 50.

Walker, Marie Clarke. "Are We There Yet? The Struggle For Equity in Canadian Unions." In Unions, Equity, and the Path to Renewal, edited by Janice R Foley \& Patricia L Baker. Vancouver: UBC Press, 2009.

Walkom, Thomas. Rae Days: The Rise and Follies of the NDP. Toronto: Key Porter, 1994.

Warskett, Rosemary. "The Politics of Difference and Inclusiveness within the Canadian Labour Movement." Economic and Industrial Democracy 17 (1996).

Welch, Catherine. "The archaeology of business networks: the use of archival records in case study research." Journal of Strategic Marketing 8 (2000): 197 - 208.

Wells, Don. "The Impact of the Postwar Compromise on Canadian Unionism: The Formation of an Auto Worker Local in the 1950s." Labour/Le Travail, 36 (Fall 1995): 147 - 73.

White, Bob. Hard Bargains. My Life on the Line. Toronto: McClelland and Stewart. 1987.

White, Julie. Sisters \& Solidarity: Women and Unions in Canada. Toronto: Thompson Educational Publishing, 1993.

------. “Looking Back: A Brief History of Everything." In Equity, Diversity, and Canadian Labour, edited by Gerald Hunt and David Rayside, 25 -48. Toronto: University of Toronto Press, 2007. 
Whitehorn, Alan. "The NDP and the Enigma of Strategic Voting." In The Canadian Federal Election of 2006, edited by Jon H. Pammett and Christopher Dornan, 93 - 121. Toronto: Dundurn, 2006.

Woodhall, Julia R. \& Belinda Leach. “Who Will Fight For Us? Union Designated Women's Advocates In Auto Manufacturing Workplaces." Just Labour: A Canadian Journal of Work and Society 16 (Spring 2010): 44 -58.

Yates, Charlotte \& Belinda Leach. "Industrial Work in a Post-Industrial Age," in Work in Tumultuous Times: Critical Perspectives, edited by Vivian Shalla \& Wallace Clement, 163 - 191. Montreal \& Kingston: McGill-Queens University Press, 2007.

Yates, Charlotte A.B. “The Internal Dynamics of Union Power: Explaining Canadian Autoworkers' Militancy in the1980s." Studies in Political Economy 31 (Spring 1990): 73 $-105$.

------. From Plant To Politics: The Autoworkers Union in Postwar Canada. Philadelphia: Temple University Press, 1993.

-----. "Defining the Fault Lines: New Divisions in the Working Class." Capital \& Class 66 (Autumn 1998): 119 - 147.

------. "The Revival of Industrial Unions In Canada: The Extension and Adaptation of Industrial Union Practices to the New Economy." In Trade Unions in Renewal: A Comparative Study, edited by Peter Fairbrother and Charlotte A. B. Yates, 221 - 243. London: Routledge, 2003. 